Historic, Archive Document

Do not assume content reflects current scientific knowledge, policies, or practices. 



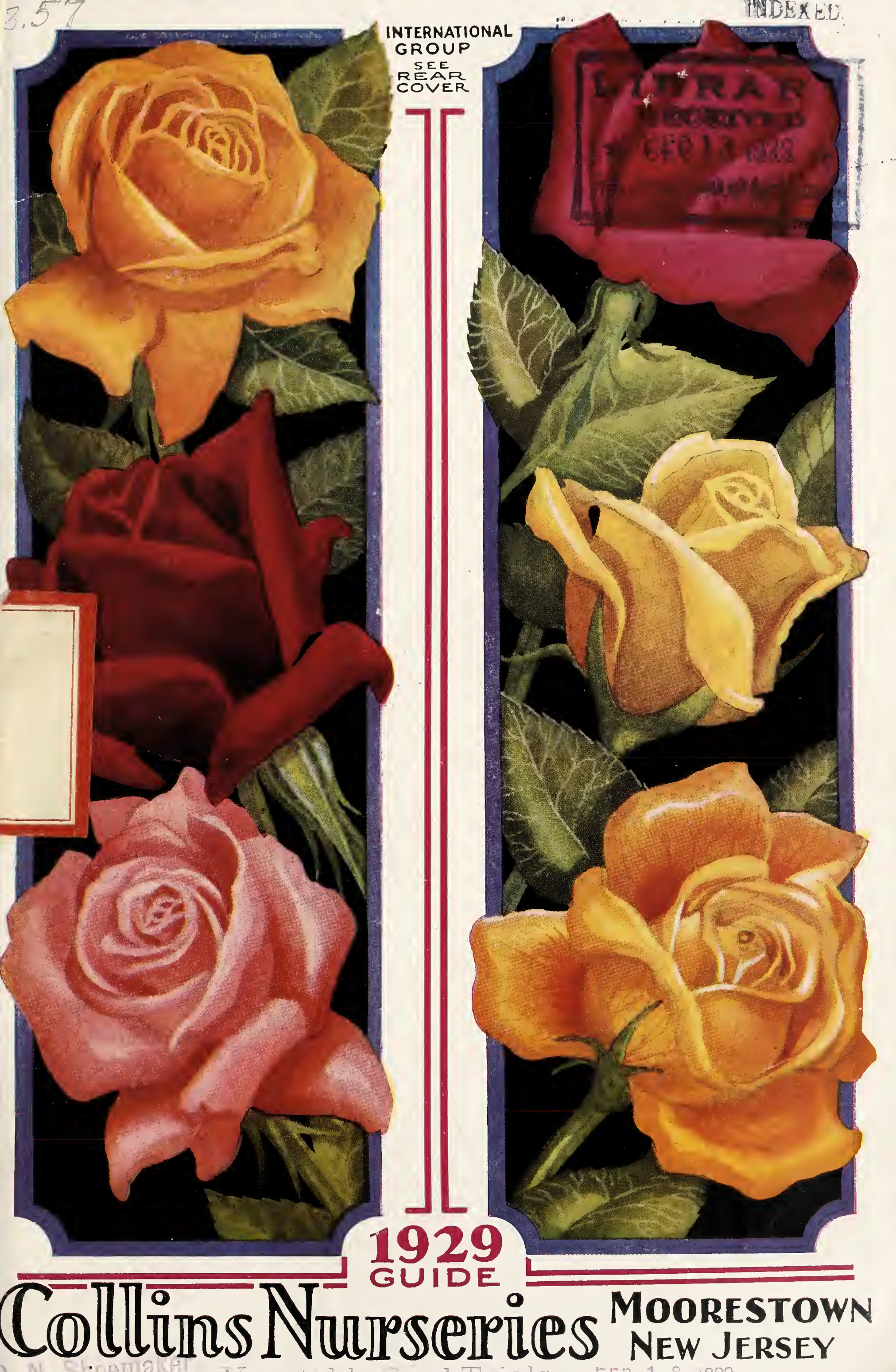


(1)

\section{M $\left(\frac{1}{1}, \frac{3}{3}\right)$}

dins

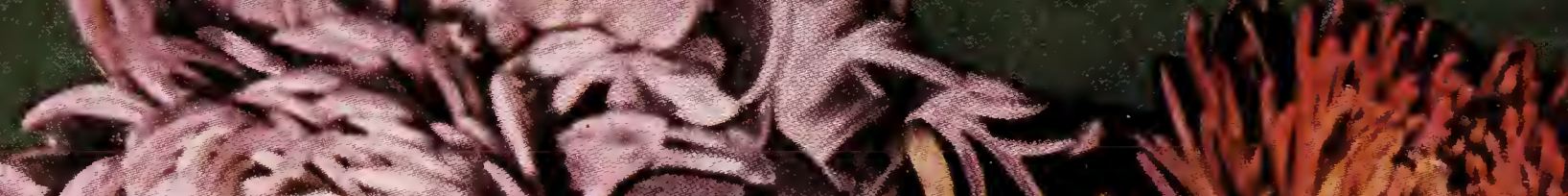

(Fi 3 ,

(1)

$4+0(2)$

- ovelow I 1 .

- regrant

$$
\text { 3. }
$$
1.4. $\frac{1}{2}$

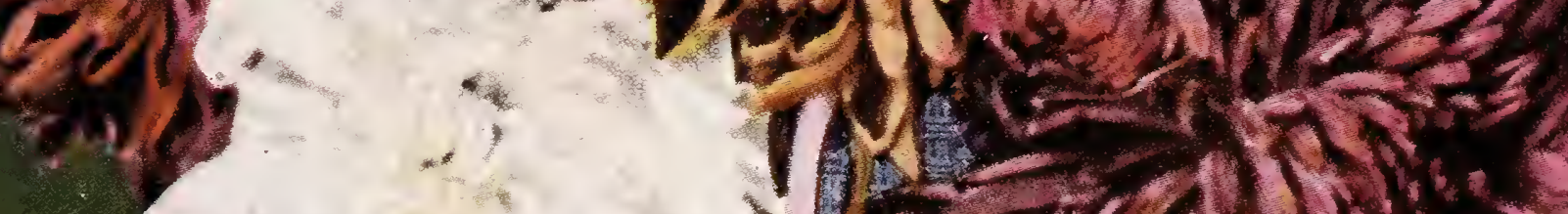

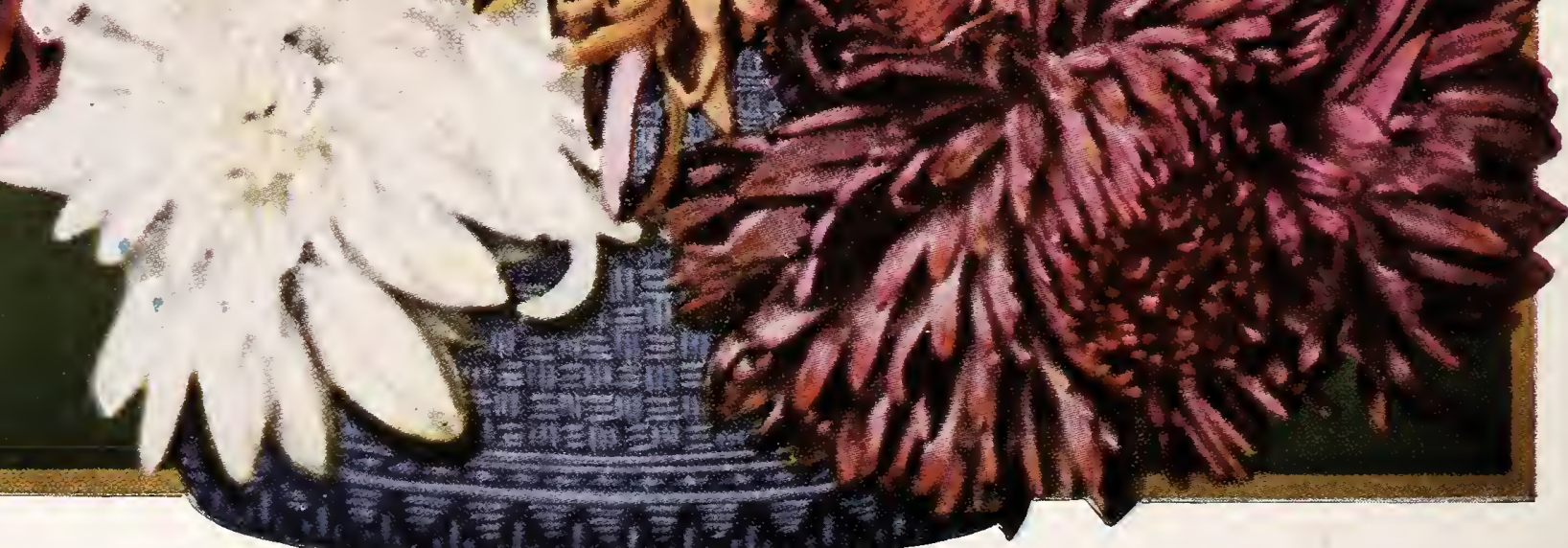




\section{For a Riot of Bloom Every Fall Plant Hardy Chrysanthemums This Spring}

Nothing else in the hardy garden so captivates us all in Fall as these "Mums." Eagerly sought by "garden beginners," cherished by the most experienced of flowerlovers. The most prolific, satisfactory and reliable of all flower favorites, the Hardy Chrysanthemums are the frame-work and backbone of the Hardy Garden in Autumn, and even after frost and snow have "put to sleep" everything else in the garden.

The "Mum" Color Photo shown on facing page, shows what one flower-lover accomplished in brightening her garden by planting the REMARKABLE SPECIAL OFFER, shown below. For as is our custom, we had this offer tested out thoroughly before it was included in our catalog.

What profusion of blooms she had! What color range! What variety of forms and shapes, astounding to the person who associates the term "hardy chrysanthemums" with the drab, dwarf flowers of our grandparents! And, marvel of marvels, the blooms shown in this color photo were picked, after a heavy snow had fallen!

\section{Collins "Mum" Color Photo Offer}

From the 30 leading kinds listed below (ball shaped, Aster Flowered, convex and incurving, tight and. formal, full opening and expanding) we choose for you a varied selection of 12 superb "Mums" covering the color range equal to or better than the 12 shown in the color photo for $\$ 1.95$ POSTPAID. (If west of Mississippi River, add 25c

Finest Aster-Flowering and Choicest Early Flowering

They will give you armloads of spicy blooms-all types and colors-which will retain their color and freshness for many days. They give an increasing yield yearly with little care. Our plantings are observed carefully year after year for greatest quantity of fnest blooms, unusual colors for Fall months, hardiness and yearly increase. Here are the remarkable varieties which led on every count:

30 Choicest Chrysanthemums, Including Largest-Flowering, Aster-Formed, EarlyFlowering Sorts, and Choicest Exquisite Single-Flower Varieties

Alice Howell. Rich orange-yellow and bronze.

Belle Mauve. Early. Delightful blush-pink.

Chrysolora. Large clear yellow.

Delmar. Early. Bright rose-pink.

Excelsior. Aster-flower. B rig h t yellow. Early.

Golden Oriole. Excellent singleflower canary-yellow. Rich.

Golden Sun. Startling brilliant yellow.

Helios. Unusual yellow type, rich chestnut-scarlet.

Ida Catherine Skiff. Delightful bronze-amber.

Idolf. Charming salmon-pink.

Joyce Strowlger. Sturdy flowers of salmon-pink, tinged bronze.
Julia. Unusual Amaranth-pink.

Kathleen May. Brilliant crimson.

scarlet. Single flower form.

LaGaronne. Buff and rose. Very early.

Lilian Doty. Large incurved soft

Lucifer. Deep ox-blood red. Large, old-fashioned.

Marie Dupont. Early, free flowering excellent pure white.

Mme. L'Argentage. P l e a s in $g$ blush-white. Aster-flower.

Mrs. Albert Phillips. Deep lavender-pink.

Mrs. C. Robinson. Deep rose-pink. Aster-flower.

Mrs. F. H. Bergen. Aster-flower. Light pink.
Mrs. H. Harrison. Early, free flowering. bluish.

Murillo Clear light rose. Aster. form.

Oconto. Old-fashioned sort. Pure white. Large.

Old Homestead. Excellent sal. mon-pink. Aster-form. An oldfashioned sort.

Philadelphia. Bright clear rose. Aster-form.

Provence. Dainty pale pink. Very early.

Red Doty. Red form of famous Lilian Doty.

Tints of Gold. Burnished old. gold and deep rich yellow. Very early.

Viola. Most unusual violet-rose.

$25 \mathrm{c}$ each; one each of the above 30 kinds, $\$ 4.75$ postpaid; $\$ 15$ per 100 , by express.

Pompon or Button Chrysanthemums and the new variety, Mrs. Calvin Coolidge, see page 43

\section{INDEX}

\begin{tabular}{|c|}
\hline 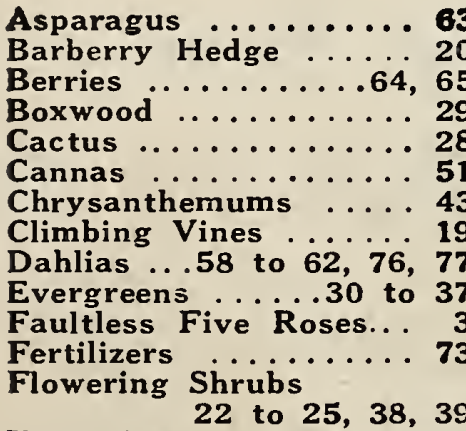 \\
\hline
\end{tabular}

Gladiolus ......52 to 57 Grapes $\ldots \ldots \ldots \ldots 66,67$

Grass Seed .........27

Hedge Plants...20, 21, 29 Instructions for Ordering ..........75

Japanese Maples ..... 29

Perennials ......40 to 49

Radio Programs

$2,12,14,18,29$ $49,57,68,74$

Rock Gardens .......50

Roses ........3, 5 to 18

Climbing ........ 10

Climbing Hybrid Tea, 11

\section{Roses (continued) \\ Cultural Hints, 15 to 18 \\ Faultless Five ......2-3 \\ Free Roses ........7 75 \\ Gold Medal ........ 5 \\ Hybrid Tea....... to 9 \\ Perpetual and Various 11 \\ Red, Red Radio and Glorious Pernet ... 13 World Wide Group- Outside Covers.}

Shade Trees ........26

Strawberries ........65 65

Sundries . . . . . . 72, 73

Vines $\ldots \ldots \ldots \ldots 72,73$

and on page 74 


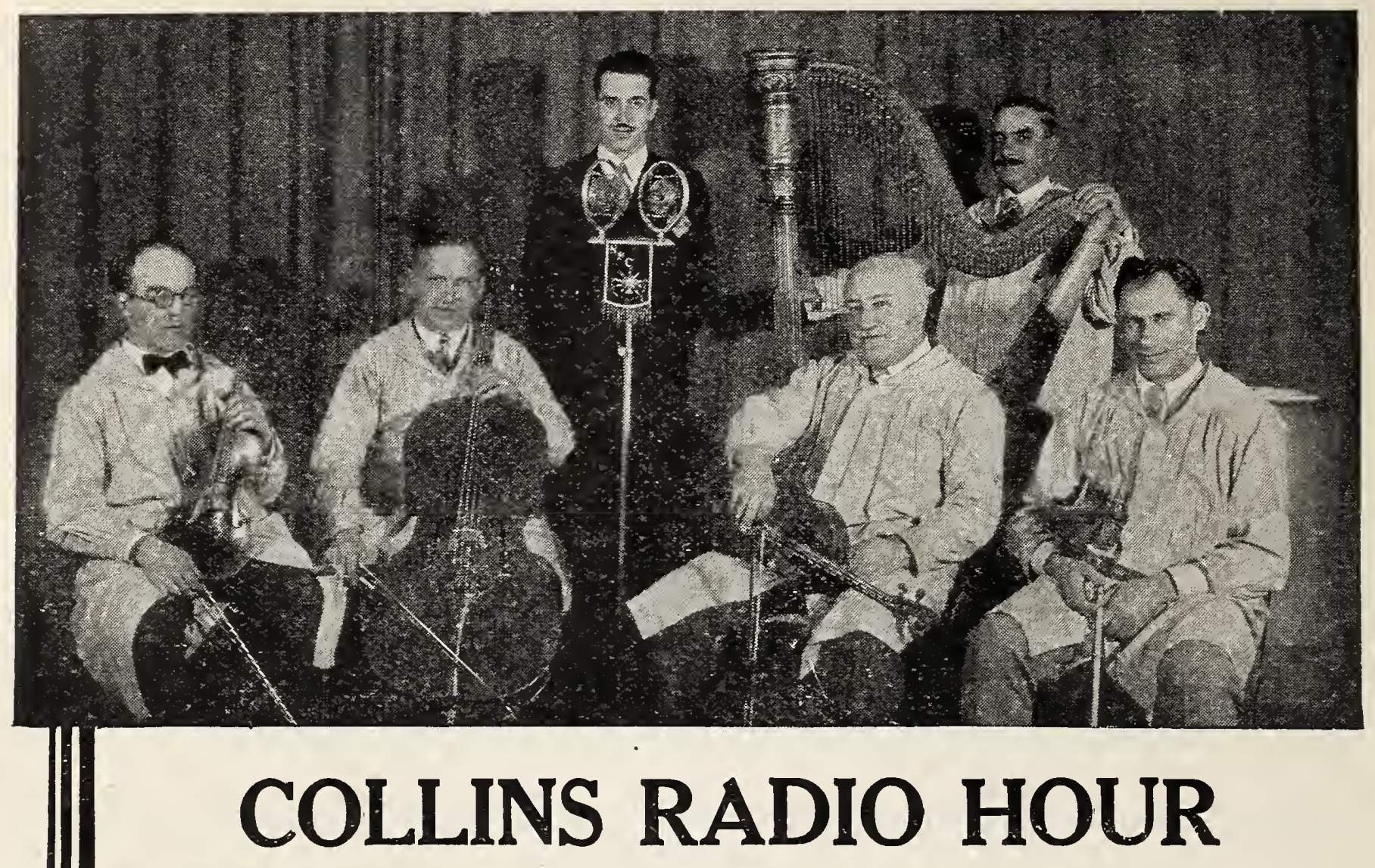

-the first radio program devoted solely to roses-has brought us thousands of letters of commendation. We appreciate these comments on the rare beauty of rose music, both vocal and instrumental, as included in these programs and on the great helpfulness of the brief rose cultural talks. Answering the many who have asked whether these programs will be given in Spring; 1929, we are glad to call attention to the programs on pages 12,14 , $18,29,49,57,68$ and 74 . Listen for these programs starting Saturday, March 2nd, over Station W. J. Z., from 6 to 6.30 P. M. Retain this catalog where it will be handy when listening-in. We appreciate your comments and criticisms.

\section{Collins Faultless Five}

(illustrated above with our tenor soloist, Mr. William Hain) are named for the famous group of Collins roses which have brought us over 100,000 new friends in recent years. Our purpose in creating this remarkable group of five roses was not to make profit, but to make this 69-year-old nursery known to thousands of new garden lovers each year. It has served that purpose in the past, and in 1929 it is sure to be even more popular than ever before. Because

\section{Collins Faultless Five}

\section{Field Grown Roses for 1929}

includes five varieties of rare merit, different from those included in this offer in the past, as requested by a host of our rose-loving customers.

Illustrations on this and facing page convey an idea of size and shape of these gorgeous roses. Color and fragrance are beyond description or conception - until you have grown these varieties. 


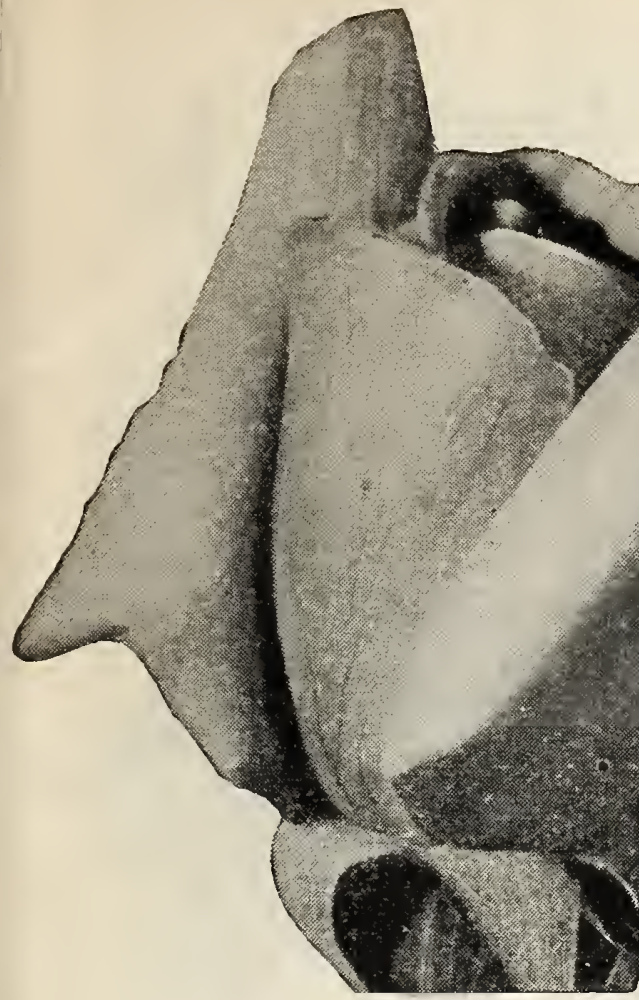

(1) SOUVENIR DE CLAUDIUS PERNET - the gorgeous, spell binding all yellow rose, illustrated on facing page. ("The prettiest blooms I ever saw." F. R. Z., Brooklyn, N. Y.)

(2) RADIANCE - the brilliant carmine pink of perfect form, which leads in practically every list compiled by rose experts.

(3) KAISERIN AUGUSTA VICTORIAthe leading rose for profusion of long pointed buds opening to a perfect white.

(4) LOS ANGELES-a luminous flame pink, toned with coral and tinted with gold at base of petals.

(5) RED RADIANCE-an unfading brilliant red sport of the delightfully formed Radiance. Bears profusely.

Never before have we had a sufficient quantity of these finest, fragrant popular varieties to offer them at less than a dollar each for 2-yr.-old bushes. Now, so long as our supply lasts, we offer all

\section{5

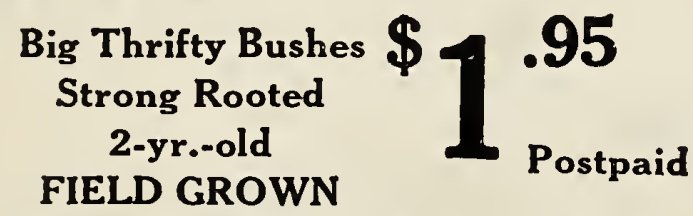 \\ (West of Mississippi River, add 20c)}

Think of it! Hardy, field-grown bushes of a size to bear this year a profusion of long-stemmed, fragrant blooms, until frost. GUARANTEED to be 2-yr.-old FIELD-GROWN bushes; which come through winter with minimum care and increase in size year after year.

ACT NOW. Only this limited allotment can be price. Orders filled in order of receipt, shipment to be made to you postpaid when planting season opens.

This group cannot be varied from one each of above varie-

ties. Other roses pages 5 to 13 , and outsido cover pages. 


\section{Permanent Growth requires Deep Roots}

A nursery business is like a tree-its future depends largely on whether the greatest growth in the earlier years is $A B O V E$ or BELOW ground

Just as some of the least permanent of trees make prodigious growth above ground during the earlier years compared to certain other deep-rooting trees which seem to make little apparent progress in that period, so this 69-year-old business has seen many concerns of a mushroom character come, flourish greatly for a few years, and disappear.

We of the younger generation in this business are constantly thrown in touch with facts which make us grateful that the business was definitely planned 69 years ago to root itself deeply in public confidence, and that that policy of the founder was persisted in over all the years by our grandfather and father. Not a season passes when we do not receive letters from pleased customers telling how their parents and grandparents bought from Collins Nurseries with the same enduring satisfaction these writers experienced.

The business has multiplied many fold; its acreage has expanded till our property extends over 400 acres; our rose bushes, evergreens, perennials, shrubs, and other products are going into every state in the United States and into many foreign countries. Yet it is our aim to keep close to the principles of the earlier vears; to keep deeply rooted in public confidence by fair dealing, the recommendation of the most dependable varieties only and the furnishing of strongly rooted plants at lowest possible prices for dependable quality. Naturally, after the care lavished in the nurseries on everything which grows here, we want it to succeed in your hands. Your enduring satisfaction is our aim.

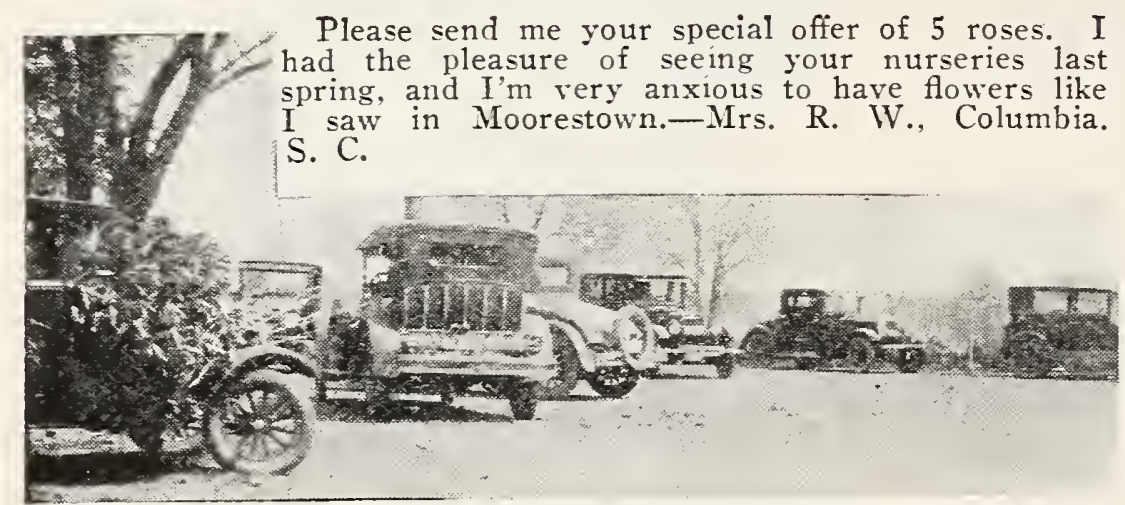

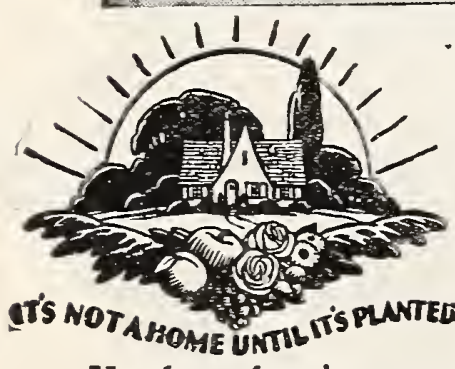

Member, American Assn. of Nurserymen

\begin{abstract}
"Waiting Autos." Each year customers from many states visit our nurseries and proudly carry away their plants.
\end{abstract}

\section{Collins Nurseries}

\section{Founded 1860}

\section{(Arthur J. Collins \& Sons, Inc.)} Moorestown, New Jersey

Come Visit Our Nurseries

See for yourself the way we grow things on our 400 acres devoted to Nurseries and Orchards. Look at our six acres of Roses with overhead automatic irrigation. See our beautiful blocks of Evergreens of all types and all ages. Our large plantings of Barberry and Privet. Realize the care lavished on the products of our Nurseries-you will see why we want to help in every way possible to assure their taking root on your property and giving you enduring satisfaction.

Moorestown is 9 miles east of Camden, on the road to Mit. Holly accessible by Penna. Railroad, by buses from the center of Philadelphia and Camden, and by excellent auto highways. Our signs point the way to the nurseries. 5 miles from Tacony-Palmyra Ferry.

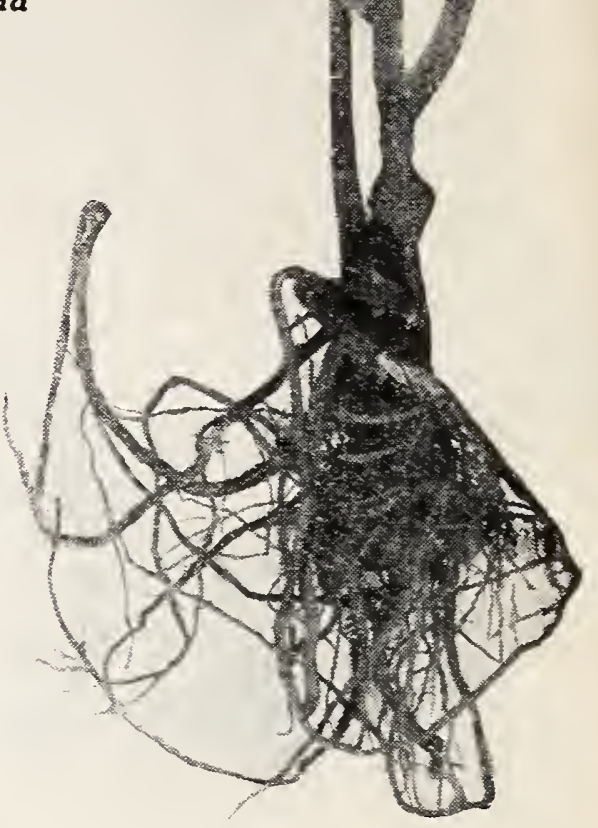

The advantages of being deep-rooted in public confidence is shown by the growth of our ROSE SALES

as shown by this chart of number of bushes sold at various periods, all lines to same scale.

Line $\mathrm{A}$ - average number per year for period prior to 1900

B - average number annually, 1900 to 1923

C - number sold in 1924

D-1925 sales

$\mathrm{E}-1926$ sales

$\mathrm{F}-1927$ sales

G-1928 sales

The hundreds of thousands of rose bushes sold in 1928, are 82 times our aver. age annual vol. ume prior to $A B C D$ D $F$ G 1900 .

Arthur J. Collins Byron C. Collins Arthur J. Collins, Jr.

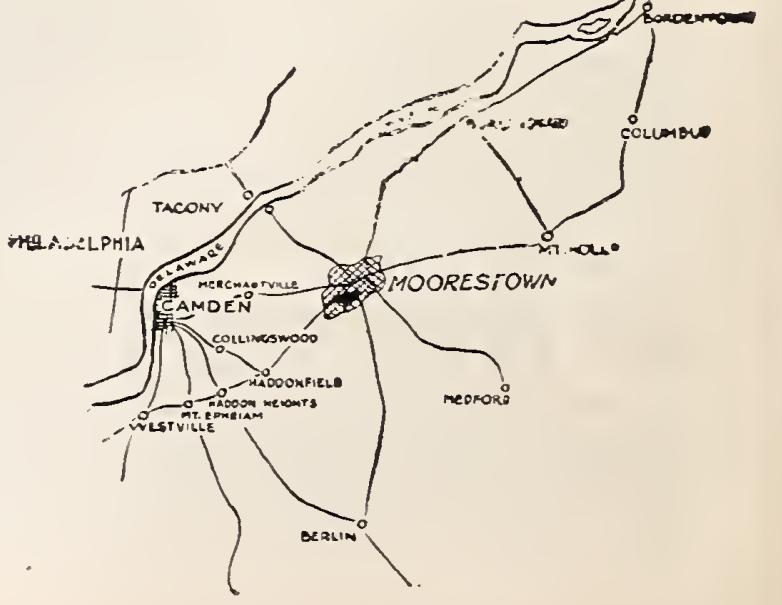




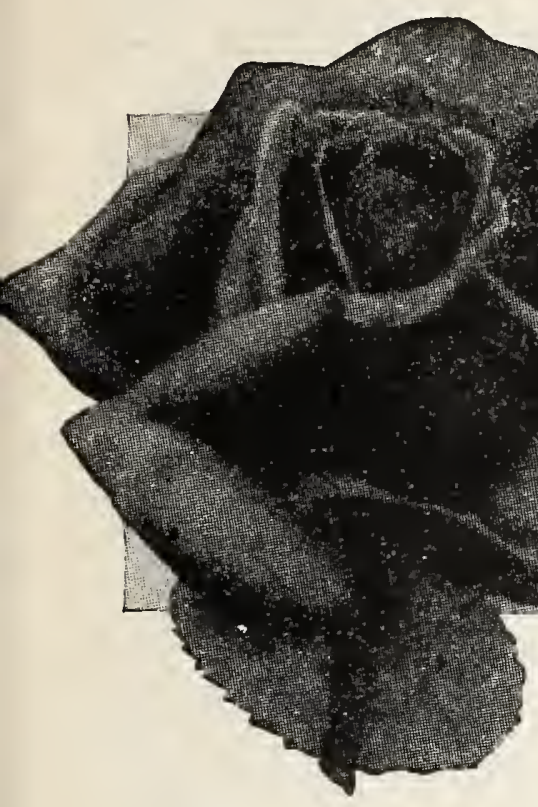

H. V. Machin

GRUSS AN TEPLITZ. Rich, scarlet flowers, blending velvety crimson, set off by beautiful green foliage. Long, stiff stems, making it valuable for cutting. Very fragrant. A strong grower and in bloom all the time.

HADLEY. One of the very finest budding roses, with its rich, velvety crimson flowers, intensely fragrant and producing very freely. Blooms continue throughout the season. Each $\$ 1.25$.

HOOSIER BEAUTY. This is a valuable rose for cutting, as the flowers are firm and last a long time. Its exquisite long buds are beautifully formed and its large full flowers of intense, dazzling crimson-scarlet are very fragrant.

H. V. MACHIN. An intense dark, almost black, scarlet-crimson rose, of vigorous and sturdy habit. Borne on long, stiff stems.

IMPERIAL POTENTATE. This is rapidly becoming one of the most popular pinks. The buds are perfectly shaped; the flowers are extra large, wonderfully formed and of a bright, glistening rose pink. Each $\$ 1.50$.

JONKHEER J. L. MOCK. These very large, perfectly formed blooms are highly scented and the blooms are produced in great profusion on strong, stiff stems. The flowers are deep, imperial pink on the inside and rich carmine and silvery-rose white on the outside.

KAISERIN AUGUSTA VICTORIA. These handsome, long-pointed buds open up into blooms of the purest snow-white. Beautifully formed roses produced on long graceful stems. The bush is a strong, free, healthy grower.

KILLARNEY. The best known of the famous Irish Hybrid Teas. One of our most popular garden varieties. The buds are large, long, and pointed with the petals deep and of great substance. Ideal for cutting. Almost continuous bloom. A whole bed of these sparkling, brilliant pink blooms is a gorgeous sight.

KILLARNEY BRILLIANT. Very similar to the Killarney, but of much brighter and more brilliant coloring and somewhat larger with a rich glowing shade of carmine.
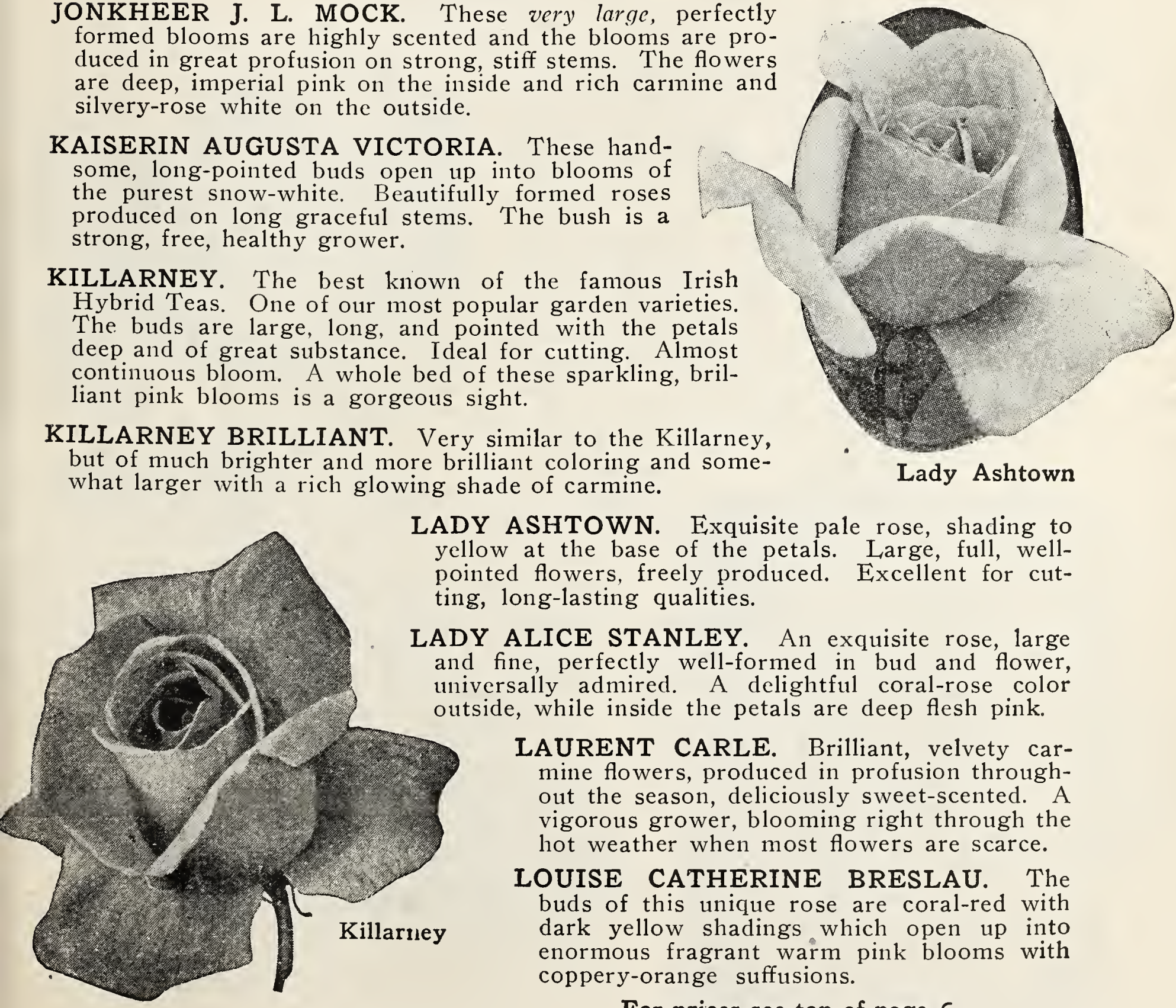

LADY ASHTOWN. Exquisite pale rose, shading to yellow at the base of the petals. Large, full, wellpointed flowers, freely produced. Excellent for cutting, long-lasting qualities.

LADY ALICE STANLEY. An exquisite rose, large and fine, perfectly well-formed in bud and flower, universally admired. A delightful coral-rose color outside, while inside the petals are deep flesh pink.

LAURENT CARLE. Brilliant, velvety carmine flowers, produced in profusion throughout the season, deliciously sweet-scented. A vigorous grower, blooming right through the hot weather when most flowers are scarce.

LOUISE CATHERINE BRESLAU. The buds of this unique rose are coral-red with dark yellow shadings which open up into enormous fragrant warm pink blooms with coppery-orange suffusions. 


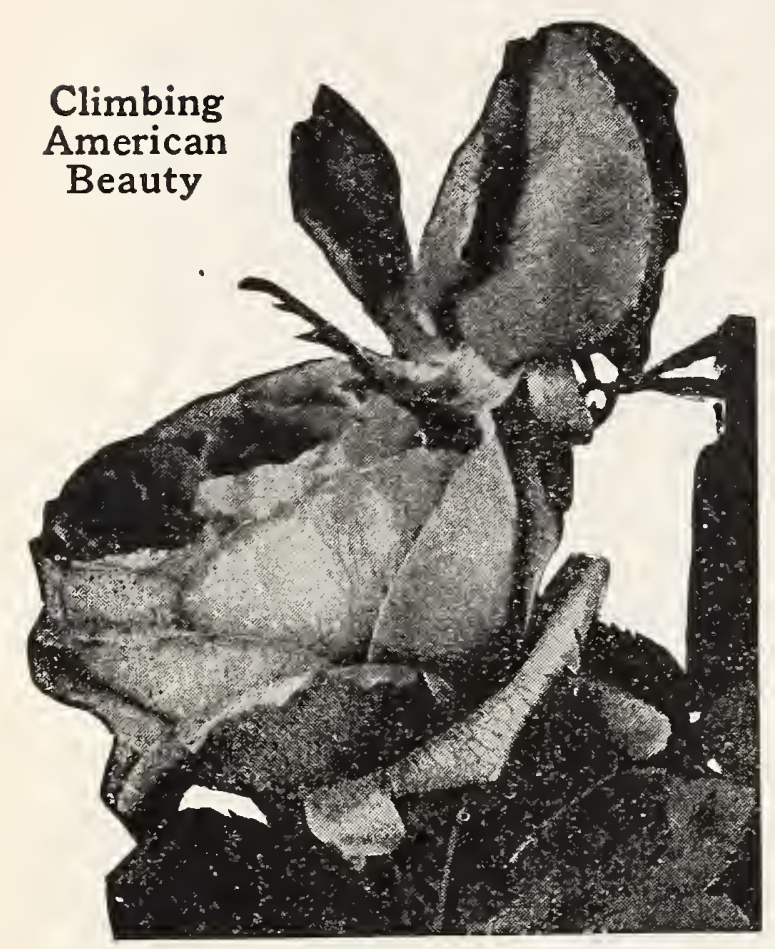

\section{Climbing Roses}

A choice selection of the finest two-year-old bushes.

CLIMBING AMERICAN BEAUTY. A very gorgeous bush in full bloom with its great quantities of rich rosy-crimson flowers borne on individual stems and has the additional quality of being exceptionally fragrant, and are fine for cutting. This is the strong est and fastest growing climber, producing its fin: blooms in May and for several weeks.

SILVER MOON. This is the finest white climbing. rose different from all other roses with its beautiful semi-double flowers $4 \frac{1}{2}$ inches or more in diameter, beautifully formed. One of the fastest climbing roses in existence, growing thirty feet in a single season.

PAUL'S SCARLET CLIMBER. This is a fine new climbing rose of vivid scarlet and bright crimson flowers, the brightest red hardy climbing rose in existence, the most brilliant addition to roses in many years, flowers produced so abundantly that they clothe the bush from top to bottom.

GARDENIA. The deep, rich golden-yellow buds, equal to those of many Tea Roses, which open into double flowers of cream, folding up at evening, are produced in greatest profusion through June and July. A strong growing hardy climber bearing large flowers excellent for cutting. Wax-like leaves and bright colored stems.

DR. W. VAN FLEET. The best flesh-pink climbing rose, bearing pointed buds that open into 4-inch flowers with a high built center full and double and delicately perfumed; stems 12 to 18 inches long. A great favorite.

AMERICAN PILLAR. An excellent new climbing rose and exceedingly fast growing with vigorous canes and glossy dark-green leaves. Flowers are rosy-pink to brilliant carmine with beautiful golden-yellow stems, often 3000 flowers on a young bush.

THOUSAND BEAUTIES. A well-known favorite, luxuriant in its growth, literally covered with thousands of bright blossoms borne in clusters and quite double of every imaginable shade from white to deep pink.

Any of above seven climbers, $90 \mathrm{cts}$. each Postpaid; $\$ 10.00$ per doz.; $\$ 75.00$ per 100; extra strong 2-yr. bushes. Any 4 of above for $\$ 3.45$; All 7 for $\$ 5.50$, postpaid.

MARY WALLACE. Named in honor of the daughter of Secretary of Agriculture Wallace, described by the Department of Agriculture as a pillar rose making a fine strong, self-supporting plant 6 to 8 feet high, with fine, glossy foliage and one that blooms with great freedom in the spring, with considerable buds produced all summer and fall. The large, well-formed flowers are mostly more than 4 inches across and are semi-double of a bright, clear rose-pink with salmon at the base of the petals. Extra size $2-y$ r.-old, $90 \mathrm{cts}$. each; $\$ 10$ per doz., postpaid.

EMILY GRAY. This is an exceptionally fine yellow, hardy climbing rose, the long and pointed buds of ideal form are a beautiful light orange-yellow, changing to paler yellow as they open into full flowers, borne on crimson-red stems. The leaves are very dark green and resemble holly leaves so that the whole bush presents a charming appearance both in and out of bloom. Very ornamental. Extra size 2 year old bushes, $\$ 1.00$ each; $\$ 11.00$ per doz., postpaid. This with Mary Wallace, $\$ 1.75$ postpaid.

PINK DOROTHY PERKINS. A clear, pale pink, petals crinkled.

\section{WHITE DOROTHY PERKINS. Pure white, very free-flowering.}

RED DOROTHY PERKINS. Clear, carmine-lake, profuse to bloom.

75 cts. each, or these Three Ramblers delivered for $\$ 1.75$, postpaid, 2 -yr. old bushes.

\section{Collins Baby Ramblers}

These dense, compact bushes grow about 18 inches high and are covered from summer until late frosts with great quantities of small roses. Excellent for cutting. Always neat. Constantly in bloom. The following, each $90 \mathrm{cts}$; $\$ 8$ per doz.: all 3 for $\$ 2.50$, postpaid. CECILE BRUNNER. "Sweetheart Rose." Loaded with delicate rose-pink blooms. CHATILLON. Fine silvery pink. Flowers in enormous trusses, glorious all season. IDEAL. Very deep, rich glowing red flowers produced in great profusion. Prices on all Climbing Roses on this page include postage and safe delivery. 


\section{Climbing Hybrid Tea Roses}

These three popular varieties produce flowers all through the season and climb over trellises, etc. Flowers are very fragrant and similar to Hybrid Tea forms, succeeding very well in sheltered positions or with winter protection.

CLIMBING GRUSS AN TEPLITZ. Rich, scarlet flowers blending to velvety crimson. Constantly in bloom.

CLIMBING SUNBURST. Beautiful yellow flowers deepening to orange at the center. Very sweet-scented.

CLIMBING LADY ASHTOWN. Exquisite pale rose pink with well-pointed flowers. Excellent for cutting.

Prices: $\$ 1.00$ each; $\$ 10$ per doz.; all three for $\$ 2.75$.

\section{HYBRID PERPETUAL ROSES}

GENERAL JACQUEMINOT. (General Jack). These brilliant scarlet-crimson flowers are borne in profusion and succeed anywhere. An old favorite, tried and true.

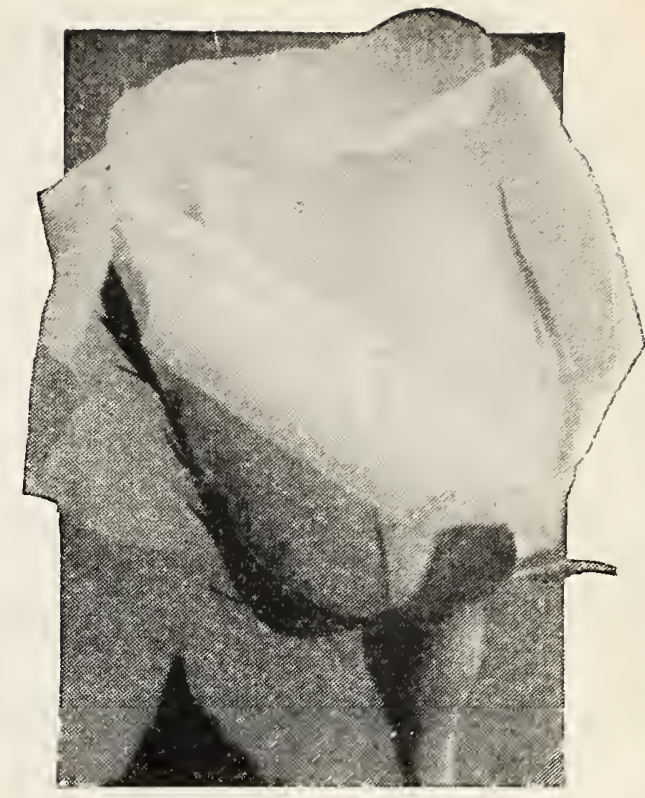

Climbing Sunburst

FRAU KARL DRUSCHKI, or White American Beauty. The best white in existence. Superb pure white, perfect in form, double flowers measuring 4 to 5 inches across. Immense long pointed buds; abundant bloomer and hardy.

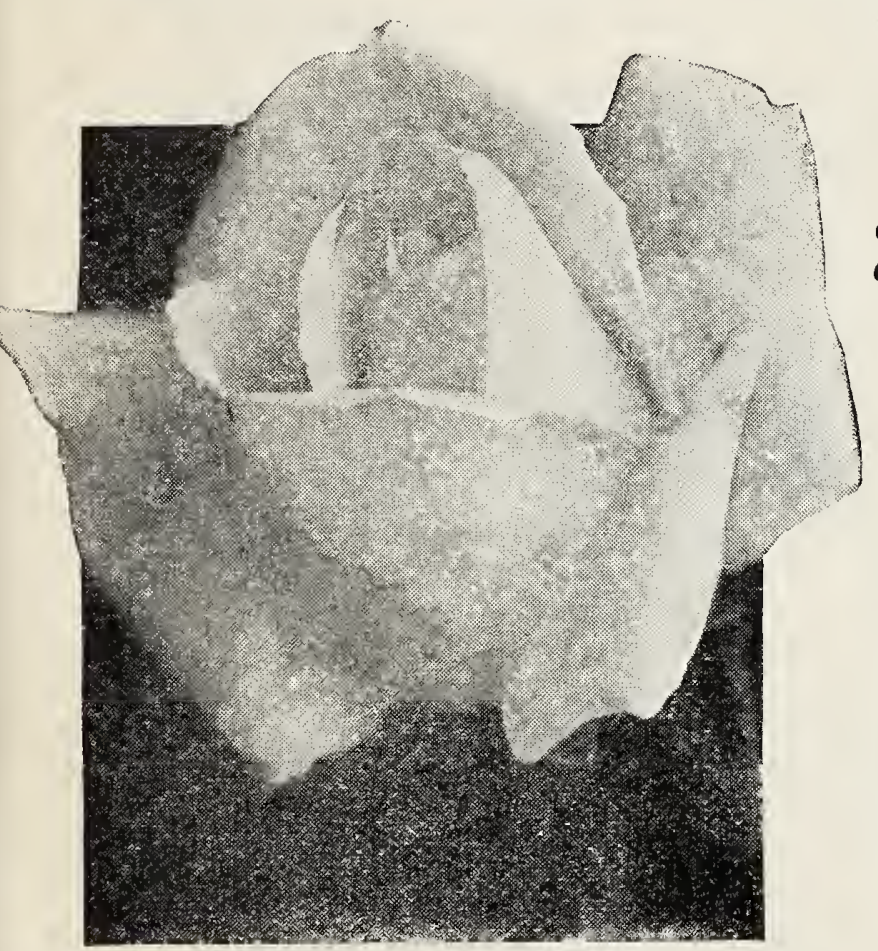

Frau Karl Druschki

GEORGE ARENDS (Pink Fran Karl Druschki). Lovely soft rose color, from the very famous Frau Karl Druschki. Marvelous form. Great size. Exceptionally sweet-scented.

Extra large, strong 2-yr. plants, 95c each; $\$ 11$ per dozen. SPECIAL OFFER: One each of the 3 above, also Mme. Albert Barbier below, $\$ 3.90$.

MME. ALBERT BARBIER. (New yellow) Though belonging to the $H$. $P$. group, this handsome new rose is practically everblooming. Produces very freely and is as hardy a grower as its parent, Frau Karl Druschki. Buds are long and handsome, with superbly formed petals like dainty shells, of gorgeous chamoispink and yellow, with golden apricot suffusion. Flowers very double, wonderfully fragrant. 2 -yr., each \$1.25; per doz. \$12.50.

\section{OTHER ROSE FAVORITES}

ROSA HUGONIS. A rare new rose from China of shrub-like growth and form. Covered with bright canary-yellow blooms in spring. Scarlet berries in the fall remain all winter. Perfectly hardy. 2-yr., $\$ 1$ each; $\$ 10$ per dozen.

F. J. GROOTENDORST. (Hybrid Rugosa Rose). Grows like a small shrub, covered with glowing trusses of crimson roses throughout summer and fall, often used as hedges. Very showy and hardy. 2-yr., \$1 each; per doz. $\$ 10$.

HERMOSA. The very popular bedding rose. Bright pink flowers of perfect shape produced very freely. Bush seems never without blooms. 2-yr., 90 cts. each; $\$ 9$ per dozen.

\section{STANDARD OR TREE-FORM ROSES}

Budded high on strong stems $3 \mathrm{~T} / 2$ feet tall, they give the effect of miniature trees when in bloom (flowers normal size, bloom all summer and fall). Gruss an Teplitz, Mme. Caroline Testout, Mme. Butterfly, Radiance, Red Radiance, Betty, Mrs. Aaron Ward, Souv. de Claudius Pernet.

Price, any of the above, $\$ 3.50$ each; $\$ 6.75$ per pair; $\$ 18.00$ per half-dozen.

\section{MOSS ROSES}

The buds of these interesting rose bushes seem to be covered with a delicate moss. 


\section{COLLNS RADID PROGRAM \\ W.J.Z.-6.00-6.30 P. M. \\ SATURDAY, MARCH 2nd, 1929}

Mighty Like a Rose-Opening Theme

. Larche Mignonne

Rose of My Heart (Vocal)

June Brought the Roses

Mighty Like a Rose (Vocal)

Love Everlasting

Helpful Talk on Rose Culture

To a Wild Rose

Rose in the Bud

Love Sends a Little Gift of Roses (Vocal)

Moment Musical

Mighty Like a Rose (Closing Theme)

\section{To avoid undependable "bench" plants- yet keep down your cost for rose bushes-}

consider carefully these Collins rose groups, every one of which consists solely of FIELD GROWN ROSES:

\section{COLLINS "FAULTLESS FIVE" Roses (Pages 2 and 3)}

The "get acquainted" offer which has added over a hundred thousand new friends to the Collins Rose Lover's group. For 1929 this includes a new list of five fine hybrid tea varieties, led by last year's favorite, Souvenir de Claudius Pernet, the gorgeous allyellow rose.

Five 2-yr. bushes, ready to bloom this year, only $\$ 1.95$ postpaid

\section{COLLINS NEW COLOR GROUPS of Hybrid Teas (Page 9)}

Three outstanding YELLOWS, $\$ 3.25$ value for $\$ 2.95$.

Three leading PINKS, $\$ 3.00$ value for $\$ 2.60$.

Three dazzling REDS, $\$ 3.25$ value for $\$ 2.85$.

Three striking BLENDED COLOR roses, $\$ 3.75$ value for $\$ 3.25$.

These four Color Groups, being potted plants, are sent by express.

\section{COLLINS GOLD CUP COLLECTION of 10 newest}

Hybrid Tea Roses, in pots (regular value \$17.50) for \$14.75 Exp. (Page 5.)

\section{COLLINS "WORLD WIDE" Hybrid Tea Group (outside covers)}

The color illustration on outside covers of these INTERNATIONALLY FAMOUS varieties gives an idea of the rare beauty of form and color of nine of this remarkable dozen group of finest fragrant roses, which is now offered for the first time at

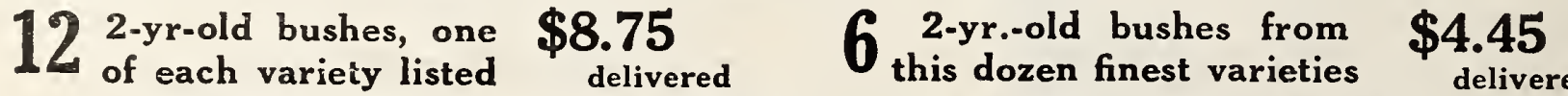
GUARANTEED to grow and bloom this season or money refunded

Were you to select the same 12 varieties from the potted field grown bushes on pages 6 to 9 , the dozen would cost you $\$ 12.75$. You save $\$ 4.00$-practically a third, because we pass along to you the advantages of all the economies in handling orders under the Collins Group Order Plan.

The illustration below shows a portion of our $61 / 2$-acre irrigated tract, all devoted to FIELD GROWN roses. At left a corner of our concrete rose storage, to which roses are moved when full grown. The floor is covered with which rosen loam, in which roses are stored while dormant. Special devices regulating moisture and temperature insure bushes ready to grow and bloom without delay in your garden.

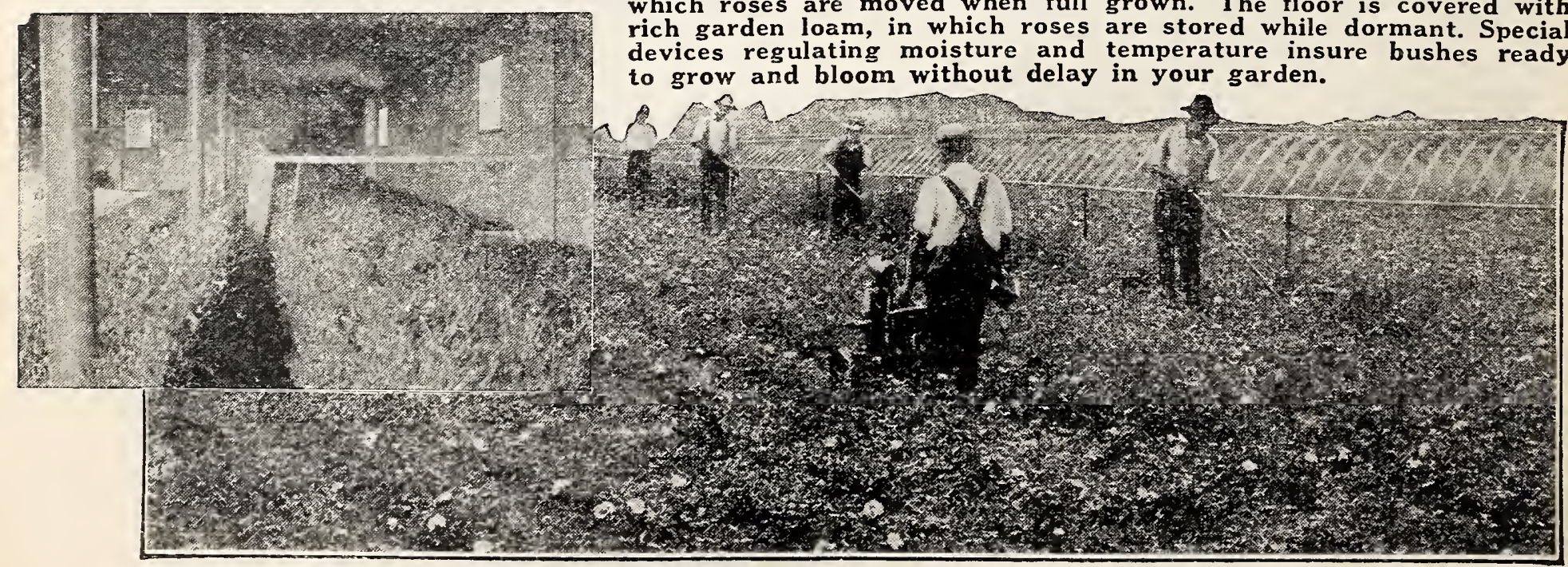




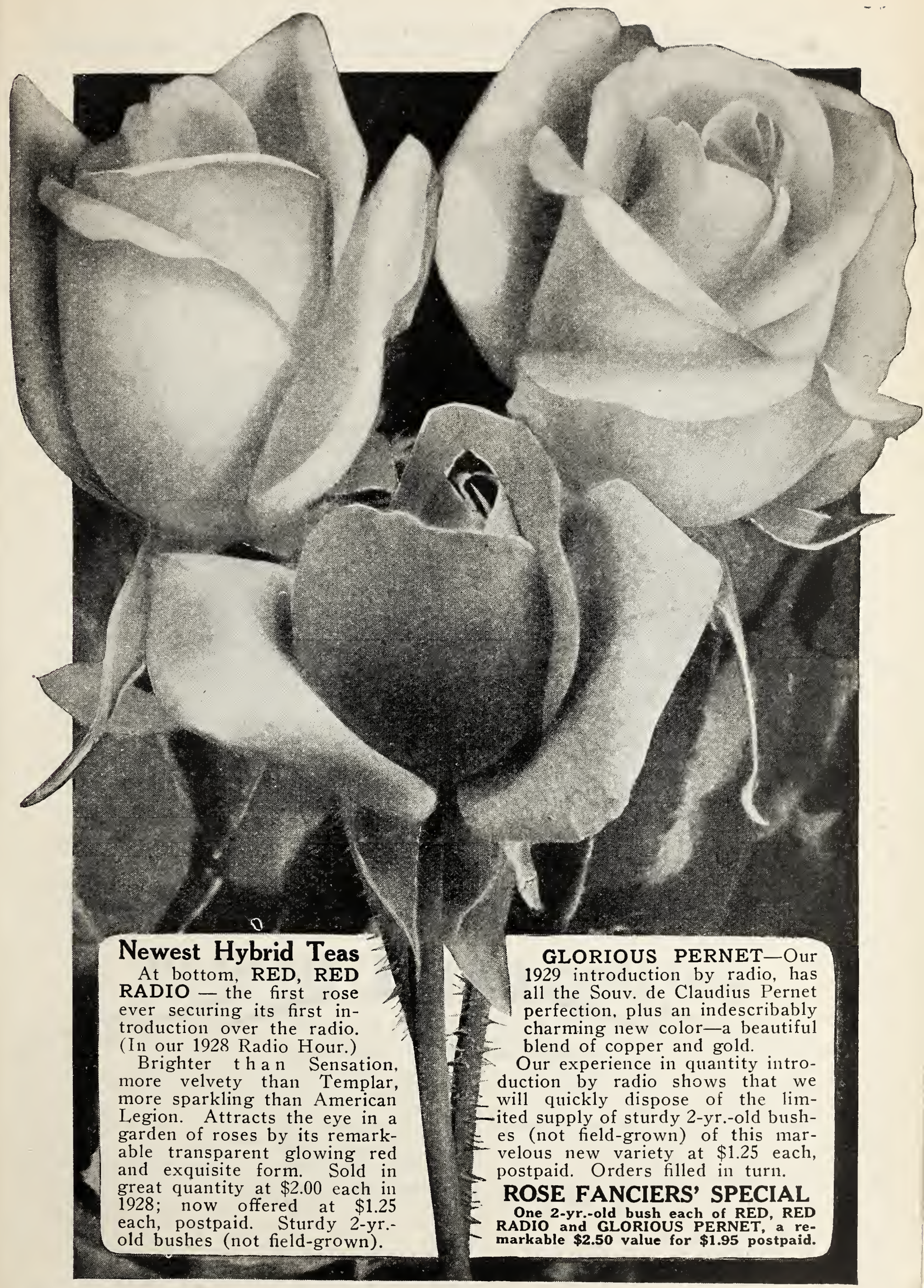




\section{Answering Your Natural Questions}

We will let our customers-all over the country-do the talking, so that you can judge, not by what we say, but by actual experiences, the results possible with Collins Roses:

\section{Will the bushes thrive?}

Roses received June $3 \mathrm{rd}$ and all are doing nicely. In 30 days we had the first bud, and 14 days later a wonderful flower on the Columbia, measuring $41 / 2^{\prime \prime}$ across. L. P. M., York, Pa.

One of my bushes had a beautiful bud on it before it was in the ground two weeks. Mr. F. H. B. Bellville, N. J.

Received the roses in best of condition. They are all growing in good shape and from all indications I will not lose a single one of them. J. J. P., Madison, $W$ is.

I am very well satisfied as each plant has rooted and bloomed all summer. H. T. T., Staten Island, N. Y.

The rose bushes received from you are the finest we ever had. Growing vigorously. Mrs. E. A. S. Houston, Tex.

\section{Do they Produce Perfect Blooms?}

$\mathrm{My}$ first bushes are blooming now, and they are beautiful. V. IV. L., James Creek, Pa.

I have 25 Collins rose bushes, and I have yet to see any finer roses. Mrs. G. B., Cornwall, N. Y.

The roses I ordered from you are just lovely now that they are in bloom. I bought over $\$ 25.00$ worth of bushes from other firms, but none came up to yours. Mrs. L. A. R., Mt. Ranier, Md.

\section{How long is their Season?}

"We are very much satisfied with your stock of roses. Our roses bloomed until the ice was hanging on them." Mr. B.. Jeannette, Pa.

My rose bushes ordered from you last summer all lived. I picked the last one October $8 \mathrm{th}$, and that is unusual for this climate. Mrs. L. T. R., Plattsburg, $\mathrm{N}$. Y

My roses bought last year blossomed for the last time just before Thanksgiving. They were beautiful. Mrs. H. E. D., West Springfield, Mass.

The roses we received from you last Spring are still blooming (10-9-28) and are unusually beautiful. Have a bouquet in the store of 4 or 5 roses every week. Everyone admires them. Mrs. R. K., Shenandoah, $\mathrm{Pa}$

\section{Will they live through. Winter?}

The rose bushes of the two previous seasons give constant pleasure by their long season of fragrant and brilliant blooms. Mrs. R. A. O., Lincoln Park, N. $\mathrm{I}$.
None of my roses bloomed more or had nicer blossoms than yours. All lived through the winter and are such nice plants this spring. W. L. S. Cleveland, $\mathrm{O}$.

For the past three years I have been having wonderful success with your roses. I have, with the last order, around 35 of your bushes. E. L. S., Brookline, $\mathrm{Pa}$.

People passing were stopped by the perfume of my roses, and when they spied them, said: "They are more perfect and lovely than any hot house roses we have seen." Mrs. L. M., Boston, Mass.

\section{Do they bear profusely?}

We have never been without buds in the cottage since the roses began to bloom last June. Mrs. M. C. S., Cloverdale, N. Y.

The Columbia had 30 buds on at one time. The Golden Ophelia is wonderful; keeps its color till the petals fall off. Mrs. F. F., Allentown, $\mathrm{Pa}$

Our roses, bought from you, bloomed beyond com. pare, flowers following so fast through summer and fall I couldn't count them. We enjoyed our Thanksgiving dinner with a centerpiece of perfect blooms cut from them. J. L., Lewiston, Me.

Wish to say that I got eighty blossoms from the six bushes of the White House collection last year which I think is fine. M. E. H., Lafayette, Ind.

The Faultless Five Roses I got from you 2 years ago are the finest $I$ ever saw and are constant bloom. ers year after year. Mrs. D. E. DeM., Aspen. Col.

\section{Are Our Customers Satisfied?}

The roses I have had from you have been a joy to me and I expect to order others in the Spring. Mrs. M. S., Morgantown, W. Va.

They are growing splendidly and have bloomed well. I am so pleased, I hope to enlarge my rose garden in the Spring. Mr. C. E. G., West Philadelphia, $\mathrm{Pa}$.

We are so well pleased with these rose bushes that we are sending you a check for 6 more. Mr. E. R. S., Midland, Mich.

I must tell you that I consider Collins Roses the best I have ever received from any nursery, and I have bought many roses. E. A. C., Shepherdstown. W. Va.

We bought one of your rose collections last year and the bushes are worth all we paid for them. They went right to blooming this year. Please send another collection. H. D. C., Ozark, Ala.

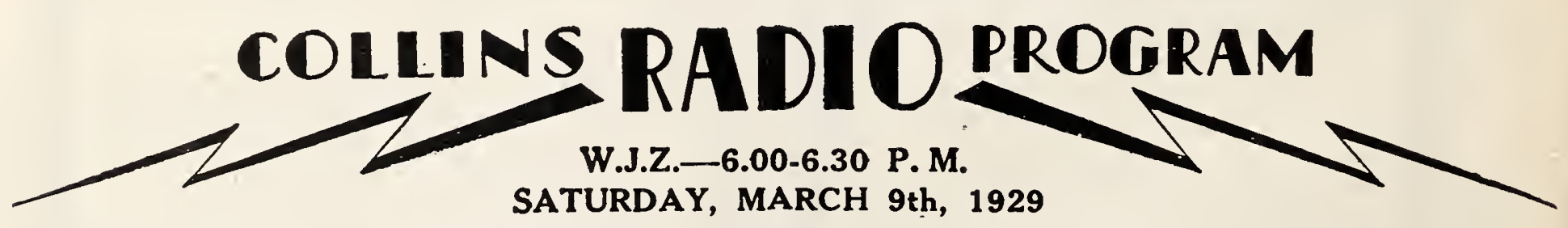

Mighty Like a Rose-Opening Theme My Heart at Thy Sweet Voice

The Flatterer

My Love is Like a Red, Red Rose (Vocal)

The Wedding of the Roses

Only a Rose (Vocal)

Helpful Talk on Rose Culture

Melody in "F"

Garden of Roses (Vocal)

Mighty Like a Rose-Closing Theme

For Radio Program of folluwing week, see page 18 


\section{We feel a responsibility- as well as a satisfaction-}

arising from our wonderfully increasing sale of roses year after year.

Of course we are gratified as the volume of orders mounts to a new and greater height each season. Three years ago we were glad to announce that

the Faultless Five tubes shipped the preceding year would-placed end to end-make a column towering

80 times as high as the Pyramids of Egypt

25 times as high as the Upper Yosemite Falls

37 times as high as the Eiffel Tower

65 times as high as the Philadelphia City Hall, or 48 times as high as the Woolworth Building.

68 times as high as the Washington Monument, at Washington.

That it would reach $2 \frac{1}{2}$ miles above Mt. McKinley, the highest peak in America; and 2 miles above $\mathrm{Mt}$. Everest, the highest mountain peak in the world.

Each of those tubes carried five rose-bushes, side by side.

For 1926, 1927, and 1928 the figures have further increased, till now we have no true foot rule with which to visualize the sale of our Faultless Five group above; to say nothing of the great volume on the Collins World Wide Group and on other rose offers.

With thousands upon thousands of new customers, some of them new converts to rose growing, it is natural that we receive many letters like the following:

The five rose bushes I bought from you in the spring have all had flowers for the second time this season. I have always hesitated about planting roses, due to the poor condition of the soil. However I followed your planting instructions and had wonderful success. The hardy condition of the rose bushes themselves had a great deal to do with their wonderful growth. If possib:e. kindly let me know the best way to take care of the bushes over the winter months and also what to do with them in the spring.

We have made it a practice to enclose with rose shipments a leaflet of Cultural Instructions which answered all such questions; but unfortunately these leaflets are lost in many cases and we have therefore decided to give the facts in condensed, easily understood form on the following pages of our catalog. SAVE THIS CATALOG, refer to these pages as the season progresses, and you will find it easy to get a profusion of blooms finer than you ever before thought possible. A little care from the beginning assures best results with least work and worry in the end.

\section{BUY ONLY FIELD-GROWN ROSES}

FIELD-GROWN for best results. Field-grown roses are fitted to garden conditions, while roses which have been "forced" in greenhouses are not. Even if it were not true that the cheap greenhouse bushes offered were discarded plants from floral establishments which have sacrificed their vitality in producing cut blooms for the floral trade for a couple seasons, there would still be the difficulty of attempting to adapt to outside garden conditions bushes which are extra tender because they were raised indoors, under forced conditions. Why burden yourself with this extra responsibility-and with difficulty in carrying your roses successfully over the Winter, when a few extra cents gives you a guarantee of Field Grown Hardiness?

Every Rose offered in this catalog-or in Collins Advertising-is FIELD GROWN with the two exceptions on page 13 , which are wonderful new introductions intended primarily for the experienced rose enthusiast. 


\section{BUY VIGOROUS 2-YR.-OLD BUSHES}

The tiny, struggling slips which are so generally offered as "1-yr.-old" bushes at low prices, are likely to produce only a single weak flower the first year, and are all too likely to die the first winter. It is' a fixed Collins policy to sell no bushes of this 1-yr.-old type-they would endanger our good reputation, because the customer who bought them would soon forget the low price he paid and remember only his complete dissatisfaction with results.

\section{SELECT TYPES AND VARIETIES}

to meet your need. If you want fragrant, brilliant blooms month after month and the sturdy character of bushes which will bear increasingly year after year with minimum winter protection, select HYBRID TEA ROSES as found on pages 5 to 9 , and in our FAULTLESS FIVE OFFER, pages 2 and 3. There are some Southern varieties of hybrid teas which you will not find in these lists, because our tests have shown that they will survive Northern winters only in picked locations and with expert care. Possibly one rose lover out of twenty might prefer that we include these, but we feel that nineteen out of twenty would be disappointed by their experiences if we did include them. Not how many varieties we can offer, but how many beautiful blooms you can get season after season from the varieties we do list, is our goal.

\section{HYBRID PERPETUALS}

as listed on page 11, also require minimum winter protection-although we do not advise omitting such protection entirely, as our grandmothers did. They are generally known as June roses, because their main crop comes in that month, although careful pruning produces a fall crop on the varieties listed. For size of bush and quantity of bloom they have an advantage which with some people is considered a partial offset for their failure to bloom every month, as Hybrid Teas do.

Among CLIMBING ROSES, the Hybrid Teas, page 11, have the great advantage of larger blooms, borne monthly, in contrast to the regular types of Climbing Roses and ramblers (on page 10), although the latter call for less winter protection and do offer wonderful flower masses in June. Each year a vastly increasing proportion of our customers report that the extra quality of the blooms and the fact that they are borne profusely every month well rewards them for the little extra care required in taking down the Hybrid Tea Climbers, laying them on the bed, and giving the whole bush a winter covering.

\section{LOCATION AND SOIL}

Rose bushes grow best where they have morning sun; shade after $3 \mathrm{P}$. M. is an advantage in preventing bleaching of colors-hence exposure to east and south is desirable. Air should circulate freely through the rose garden. The protection of a house or trees to the north to serve as a windbreak is an advantage.

If bed must be close to a tree use tar paper placed vertically to keep tree roots from growing into the rose bed and stealing the nourishment from the bushes.

The rose bed should not be placed in locations where the ground is always wet. The finest Hybrid Tea varieties may form roots 18 inches deep, therefore the rose lover who gets the most mammoth blooms and in greatest profusion when he must use a wet location, is the one who digs his rose bed to a depth of full two feet and places stones or similar loose material in the bottom six inches to assure drainage under all conditions.

While a clay loam is preferable for roses, any ordinary soil will do. Too heavy soils are readily lightened with Hyper Humus (page 73); too light soils give best results if well rotted cow manure and hardwood ashes are added. Grass cuttings and other humus turned under well helps to enrich and lighten soil. Hyper Humus keeps soil from baking, preserves moisture, keeps down weeds, and supplies good organic material.

\section{SHAPE AND SIZE OF BED}

Rectangular beds make rose care easiest. Since rose bushes are best planted in two rows with 18 incines between all bushes and a foot from the edge of the bed, the maximum width of bed is $3 \mathrm{I} / 2$ feet. Three rows require 5 -foot width. A bed $9 \mathrm{ft}$. long by $3 \mathrm{r} / 2 \mathrm{ft}$. wide would easily provide for the dozen WORLD-WIDE roses described nי outside cover pages. We have had many cases where people told us of remarkable results with 11 roses planted in a bed only $2 \mathrm{ft} .9 \mathrm{in}$. wide and less than $8 \mathrm{ft}$. long, 
placing six World-Wide roses at the rear 15 inches apart and the Faultless Five staggered in front, forming triangles with the bushes fully 15 inches apart.

\section{CARE ON ARRIVAL}

More rose bushes fail to grow because they are left lying around unprotected, exposed to wind and sun than from any other single cause. If possible, arrange to plant them promptly on receipt. We make every attempt to protect them well in the mail-our standard packing methods have brought us wonderful letters of praise from South America and the Canal Zone. But if you open the package and leave it standing in the sun and air while you dig your rose bed, the moisture around the roots which we so carefully preserve is lost. Avoid this. Open the package indoors or in the shade, away from wind. If not ready to put them in ground permanently, be sure you put the roots in a bucket of water and throw a newspaper over the bucket. Even bushes which are badly shrivelled and look almost dead can be made to produce better roses by putting them completely underground for several days, than can the finest bushes ever produced if they are exposed before planting to sun and rain.

A cloudy day is best for planting. But don't wait too long after receiving roses for such a day. Plant them right and protect them with newspapers for a couple of days against the hottest sun, and they will thrive. We advise pruning each limb back to within 6 inches of the main trunk.

Illustration shows (at center) proper depth for planting. Be sure the hole has been dug large enough; roots must not be cramped. A cone of earth below your bush holds the roots apart while planting. As each rose bush is planted, fill earth to $2 / 3$ of depth and water and tread earth down firmly above roots to drive out air-holes around roots, being careful not to skin bark. Then fill remaining with loose earth and don't pack.

\section{FEED YOUR ROSES}

Newly planted rose bushes are like children. Their first cry is "When do we eat?" The rose bed should be made of best top soil, and Sheep Fertilizer or well rotted manure added.

Nitrate of Soda ( $3 \mathrm{oz}$. to 5 gallons of water is enough for that dozen bed) supplies the food needed to make the plant grow sturdy and vigorous. Safest to use it in water as directed, not oftener than once a week. Box containing four 3-oz. packages, 35 cts. postpaid. Quotations on larger quantities on request. To stimulate great production of roses and brightest coloring, Bone Meal supplies the needed phosphorus. One pound is enough for that dozen bed.

To keep the bushes healthy and vigorous-for these roses bloom every month till late fall frosts come, unleached wood ashes supply the potassium needed. 2 oz. per plant, twice a season, is plenty (page 73 of catalog). Potassium sulphate can also be used, a tablespoonful to four gallons of water, applied every ten days during first two months after planting bushes.

We have made up a Special Rose Bed Fertilizer package for your convenience: 5 lbs. Bone Meal, 50 cts.

10 lbs. Sheep Fertilizer, 75 cts. Four 3-oz. packages Nitrate of Soda, 35 cts.

The entire lot, value $\$ 2.20$, for $\$ 1.95$ Postpaid to 4th Postal Zone

Sufficient for 24 rose bushes for one year; or a dozen for two years or more.

DO NOT USE FERTILIZERS after August 15th. It is not safe to force new shoots then; the bush should ripen to best withstand winter cold.

\section{DURING SUMMER}

Do not mound the earth up close to the rose bush, or it will send the moisture away from the roots. A rose bed should be flat. If any shoots with 7 to 9 leaf groups come up from the roots (due to improper depth of planting, or extra vigor of roots), remove them; they draw strength from the bush and will bear no roses. In periods of drought, water the ground well in the early mornings and place Hyper Humus (page 73), grass cuttings or old leaves close to bushes to keep soil from baking and to conserve the moisture. This is called mulching.

Remove weaker, smaller buds along any stem, to make terminal flowers larger and better. Remove full blown flowers, leaving more strength for new flowers. In cutting blooms, cut to within two inches of main stalk and next month new flowers will appear at same place.

Drawings on these pages used through courtesy of Department of Agriculture 


\section{WINTER PROTECTION}

Contrary to general belief, it is safest to keep rose bushes cold throughout the winter (rather than warm) thus preventing alternate freezing and thawing. In this latitude if the plants become frozen in December and remain that way until the latter part of March, they survive best. One safe, easy method-which we practice here at our Nurseries-is simply to cover ground around and between bushes with salt hay after ground has frozen hard (to $1 \mathrm{ft}$. depth). Almost any feed dealer in your locality carries that product, which is inexpensive and easily applied. A few light branches can be placed on top to keep hay in place during the winter. Don't place hay on beds until ground is thoroughly frozen and don't remove until danger of heavy frosts is past, usually the early part of April when the magnolia has burst into bloom. Remove only gradually, so that previously protected wood is not injured by sudden exposure to wind and sun.

Another satisfactory method is to tie up branches about November 15th to 20th and mound dry earth around plant, 8 to 12 inches high-this protects the eyes of the bush. After these mounds are frozen hard cover them with leaves or salt hay, preventing alternate freezing and thawing.

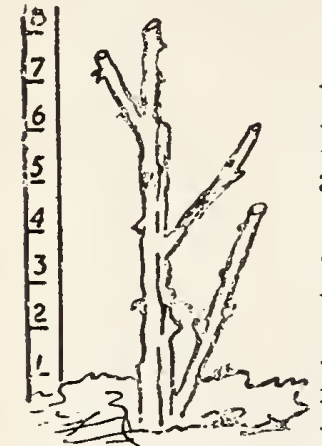

Rose Bush after trimming.

\section{SPRING PRUNING}

All dead, unripe and weak limbs should be removed. Trim for a wellbalanced bush with strong stems growing outward-severe pruning brings high quality blooms. Keep the center open-2 or 3 strong branches being ample. Trim Hybrid Tea roses once only in late March or early April (see illustration); Hybrid Perpetuals after the June crop is over; and Climbing Hybrid Tea roses only very lightly. Cut above an eye or bud which points outward, making a clean slanting cut as shown at left.

We are glad to hear from you regarding your methods and results. Remember our interest does not cease with the sale. Since 1860 this Nursery has been noted for its helpful service to garden lovers. We want to help you; ask us any questions; get the advantage of our long experience.

\section{INSECTICIDES AND FUNGICIDES}

Are frequently needless if the rose bed is made right, $i$. e., kept lower than the surrounding ground so that the watering process is one of flooding the bed, and if ordinary manure is not used for mulching. Manures are breeding places for fungi and insect pests; while wetting the foliage tends to make plants liable to black spot and mildew. If your conditions require that you sprinkle with a hose, wetting the foliage, it is best to water your roses in the morning.

FUNGTROGEN. Recommended as preventative of and remedy for Mildew, Black Spot, and Fungus diseases. Does not discolor foliage. Pint $\$ 1.25$; quart $\$ 2.00$.

INSECTROGEN is a poison, fungicide, and fertilizer protecting against leaf chewing insects, as well as against black spot. Half pints $\$ 1.00$; pints $\$ 1.75$; quarts $\$ 2.75$.

COLLINS ALL-IN-ONE MIXTURE-A dry dusting mixture of $11 / 2 \%$ Nicotine, $9 \%$ Arsenate of Lead, and $65 \%$ Sulphur; controls black spot and mildew and safeguards against both chewing and sucking insects. $1 \mathrm{lb}$. 75 cts.; 5 lbs. $\$ 2.50$.

BLACK LEAF 40 is a concentrated nicotine solution especially valuable against rose aphis-the plant lice which prey on new shoots and buds-and against rose slugs, which are on under side of leaves. 1 oz. 35 cts.; $1 / 2$ lb. $\$ 1.25$.

\section{ALL INSECTICIDES BY EXPRESS-CANNOT BE MAILED}

If you cannot get LIQUID SPRAYERS or DUST GUNS in your locality, we will gladly supply or quote prices.

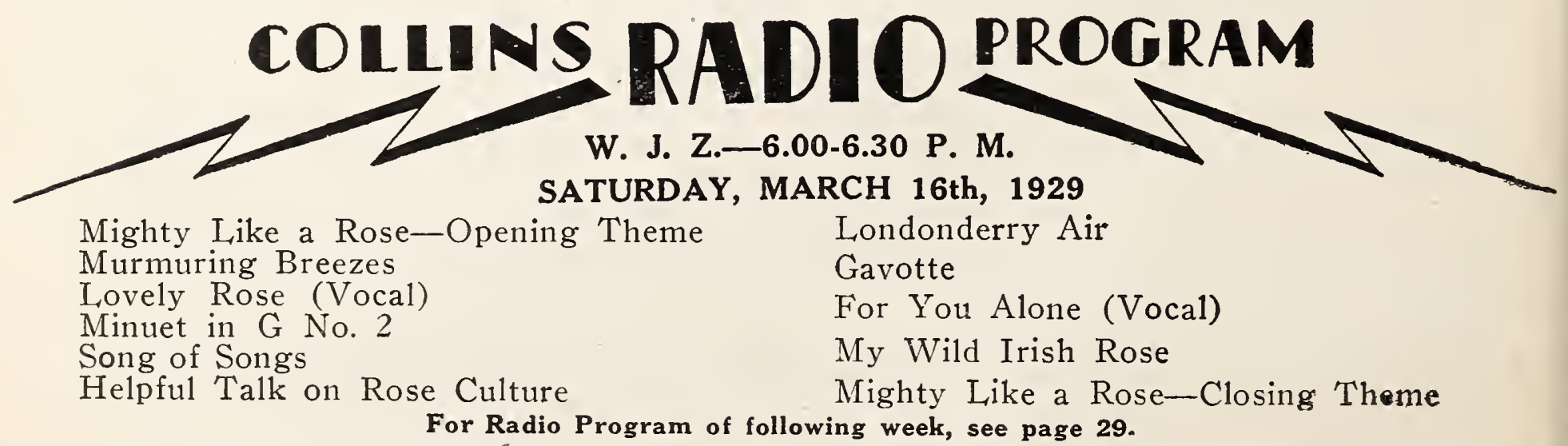




\section{Vines and Climbers CLEMATIS}

Jackmani. Very popular, rich purple flowers. The plants like moist, rich, fertile soil (not sour); set the crowns 3 inches below the surface. Postpaid; each 90 cts.; per dozen $\$ 9.00$; strong vines.

Paniculata. Flowers small, rich creamy white, borne in handsome clusters. The sweetest of all Clematis, one of the hardiest and easiest to grow. Good, strong 2-yr. plants, 50 cts. each, 4 for $\$ 1.50$; extrasize, 3-yr. plants, 75 cts. each, 4 for $\$ 2.50$, all postpaid.

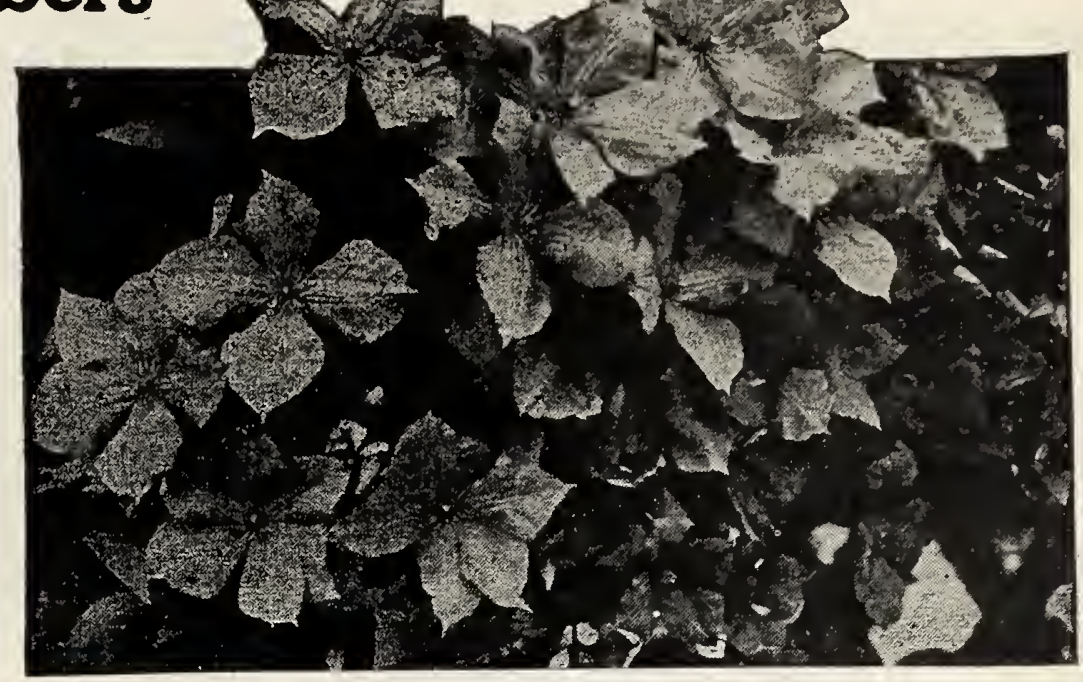

Clematis

\section{HONEYSUCKLES}

Everblooming Honeysuckle (Heckrottii). Color is crimson-carmine on the outside of the flower, which contrasts beautifully with the golden apricot of the inside as the flower opens. Blooms unceasingly all season.

Red Coral Honeysuckle. A hardy, rapid grower, suitable for rockwork, walls, etc. Flowers coral-red, very pretty.

Prices of above 2 Honeysuckles, 2 -yr., each 75 cts.; per dozen $\$ 7.50 ; 3$-yr., each $\$ 1.00$; per dozen $\$ 10.00$; all postpaid.

The Beautiful Halliana Honeysuckle. This variety is intensely sweet-scented. It is a strong, clean, neat grower, perfectly hardy, almost evergreen, with leaves that shine as if varnished; constant and most profuse bloomer; flowers buff yellow, passing to white. 2 -yr., 50 cts. each, $\$ 5.00$ per doz.; 3 -yr., $75 \mathrm{cts}$. each, $\$ 7.50$ per doz., all postpaid.

\section{IVY}

Japan, or Boston (Ampelopsis Veitchii). For covering houses, churches, schools, etc., this vine has no equal. The handsome, deep green foliage changes in autumn to crimson. Extra strong, 2 -yr. plants, $60 \mathrm{cts}$. each, $\$ 5.00$ per doz., postpaid.

American (A. quinquefolia). The true Virginia Creeper; hardy and noted for its brilliantly colored foliage in autumn. 2 -yr., $40 \mathrm{cts}$. each, $\$ 3.50$ per doz.; 3 -yr., 60 cts. each, $\$ 5.00$ per doz., postpaid.

Hardy English (Hedera helix). A hardy climber. Dark, glossy ever green leaves. 65 cts. each, $\$ 6.50$ per doz., postpaid; large size 85 cts. each, $\$ 8.50$ per doz., express.

\section{WISTARIAS}

Collins wistarias are valuable wherever tall-growing climbers are wanted. They are hardy, rapid growers, and the flowers are borne in long, pendulous clusters early in the season. Our plants are grafts (and cuttings) from specially selected stock, hence they are sure bloomers. For best results they should be planted in deep, rich earth, but they will thrive in sandy soils.

Chinese Blue. Lovely violet-purple flowers; deliciously sweet. 2-yr. grafted vines, sure-to-bloom, $\$ 1.00 ; 3$-yr., $\$ 1.25$, all postpaid.

Chinese White. Very similar to the Blue Wistaria. The flowers are attractive, pure white, and very sweet scented. Grafted vines, sure-to-bloom, 2-yr., $\$ 1.25 ; 3-\mathrm{yr} ., \$ 1.50$, all postpaid.

\section{Other Climbing Vines}

DUTCHMAN'S PIPE. Curious flowers shaped like pipes. This is a fast growing vine, having large foliage making dense shade. Postpaid; 2 yr. $85 \mathrm{cts}$ each; $\$ 8.50$ per dozen.

KUDZU VINE. One of the most rapid-growing vines in cultivation; growing to 50 or more feet in one season. The large foliage makes dense shade and bears small rosypurple blossoms in summer. Just the thing where you want to cover an unsightly fence or drape an arbor in a very short time. 2-yr., $75 \mathrm{cts}$. each, postpaid.

SILVER LACE VINE. A vigorous, strong plant, attaining a height of 25 feet or more and producing great foamy sprays of white flowers, rose-tinted, in spring and again in autumn. 2-yr., $85 \mathrm{cts}$. each; $\$ 8.50$ per dozen, all postpaid. 


\section{Japan Barberry Plants (Berberis Thunbergi)}
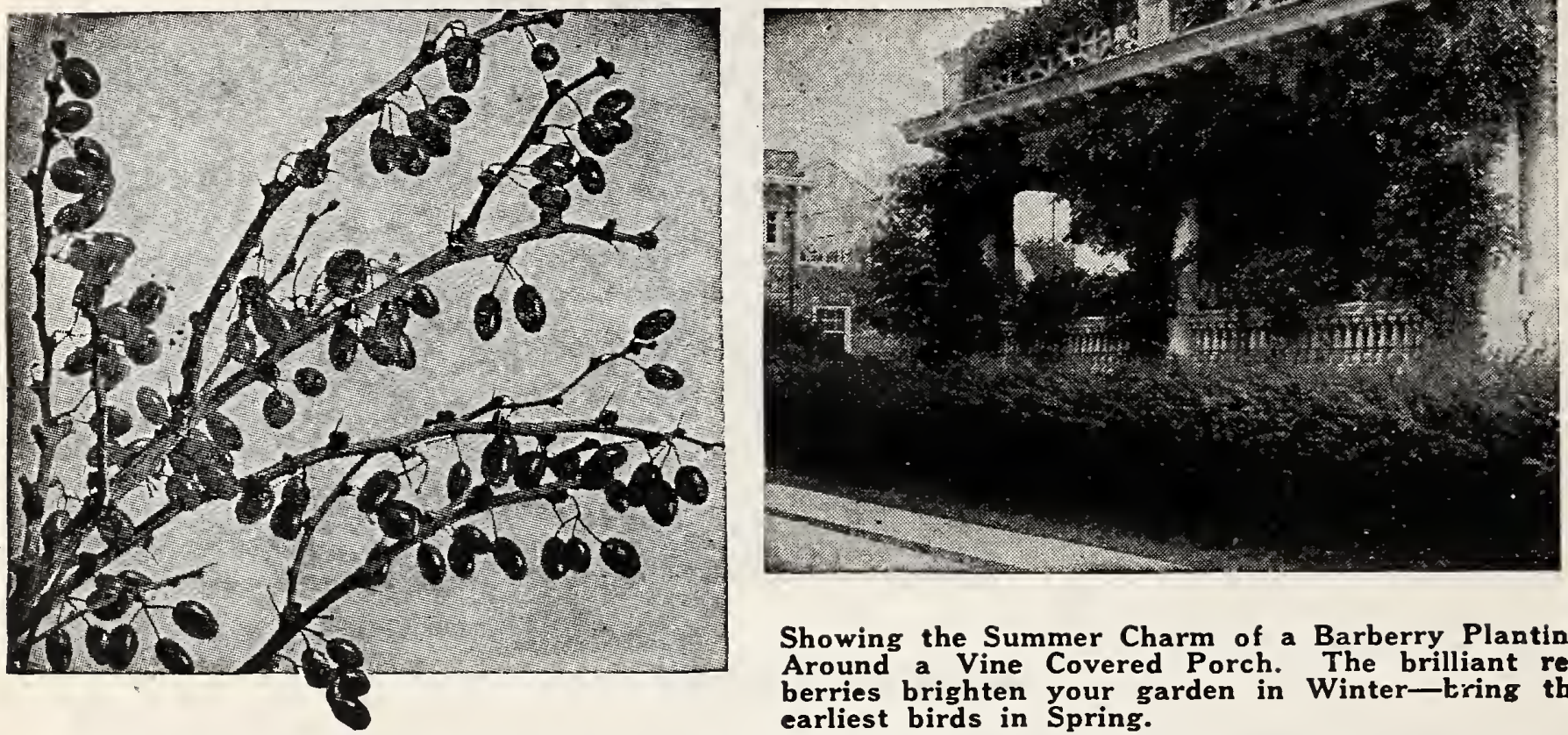

Showing the Summer Charm of a Barberry Planting Around a Vine Covered Porch. The brilliant red berries brighten your garden in Winter-Ering the earliest birds in Spring.

"If Winter Comes" and leaves your garden more desolate each week-if you long for a dwarf hedge that will supply the touch of brightness throughout the Winter, that will bring the robins to your garden to feast in early Spring before the worms are above ground, investigate this Barberry offering NOW.

No Disease-No Insects attack this species of Barberry. Highly recommended by all authorities. The dangerous sort, Berberis Vulgaris, we have never handled.

\section{THE IDEAL HEDGE PLANT}

For a dwarf hedge Japan Barberry is ideal. The branches are gracefully curved, and grow so thickly they make a dense hedge. You need trim it only four or five times a year to keep it low, bushy and compact. Plant one foot apart.

Throughout the summer the foliage is a beautiful green and very pleasing, changing to a fiery blaze of bright orange and scarlet in autumn, rivaling the changing maples and oaks. In winter its brilliant red berries shine gaily through the glistening ice on the branches and are the delight of the earliest birds in spring which seek them eagerly. Our plants are well-rooted, well-grown, and very bushy.

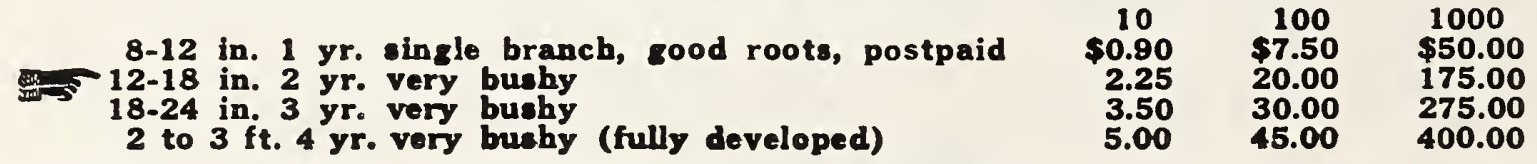

SPECIAL OFFER: We shall send you 12 careiully selected strong plants well branched and well rooted (12-18 inch size) for $\$ 2.50$ postpaid. They are so hardy they thrive anywhere.

The above text, originated by us, has been widely copied. That's easy, but to copy the quality of these Collins-grown Barberry Plants is not so easy.

\section{New Red-Leaved Japanese Barberry}

(Berberis Thunbergi Atropurpurea) Introduced for the first time in America.

New. Being sold autumn 1926 for the first time. The new Red-leaved Barberry is an outstanding novelty and unquestionably is the most valuable ornamental shrub that has been offered for years. A specimen that should be on every lawn.

It is identical in habit of growth with the popular Japanese Barberry and its foliage from when it develops in early spring until fall assumes a rich bronzy-red color. In the fall it takes on the brilliant varied colors of ordinary Japanese Barberry in an intensified form, holding its bright, scarlet berries throughout the entire winter.

It is a true Rust-Resisting Sport of Berberis Thunbergi-tests by the Department of Agriculture have shown that it does not harbor wheat rust. as does the Vulgaris type
1 year, super-size plants............. $\begin{gathered}\text { Each } \\ \$ 0.75\end{gathered}$
2 year, heavy and stocky............. \$ 1.00
Per Doz.
$\$ 7.50$
10.00
Per 100
$\$ 50.00$ 


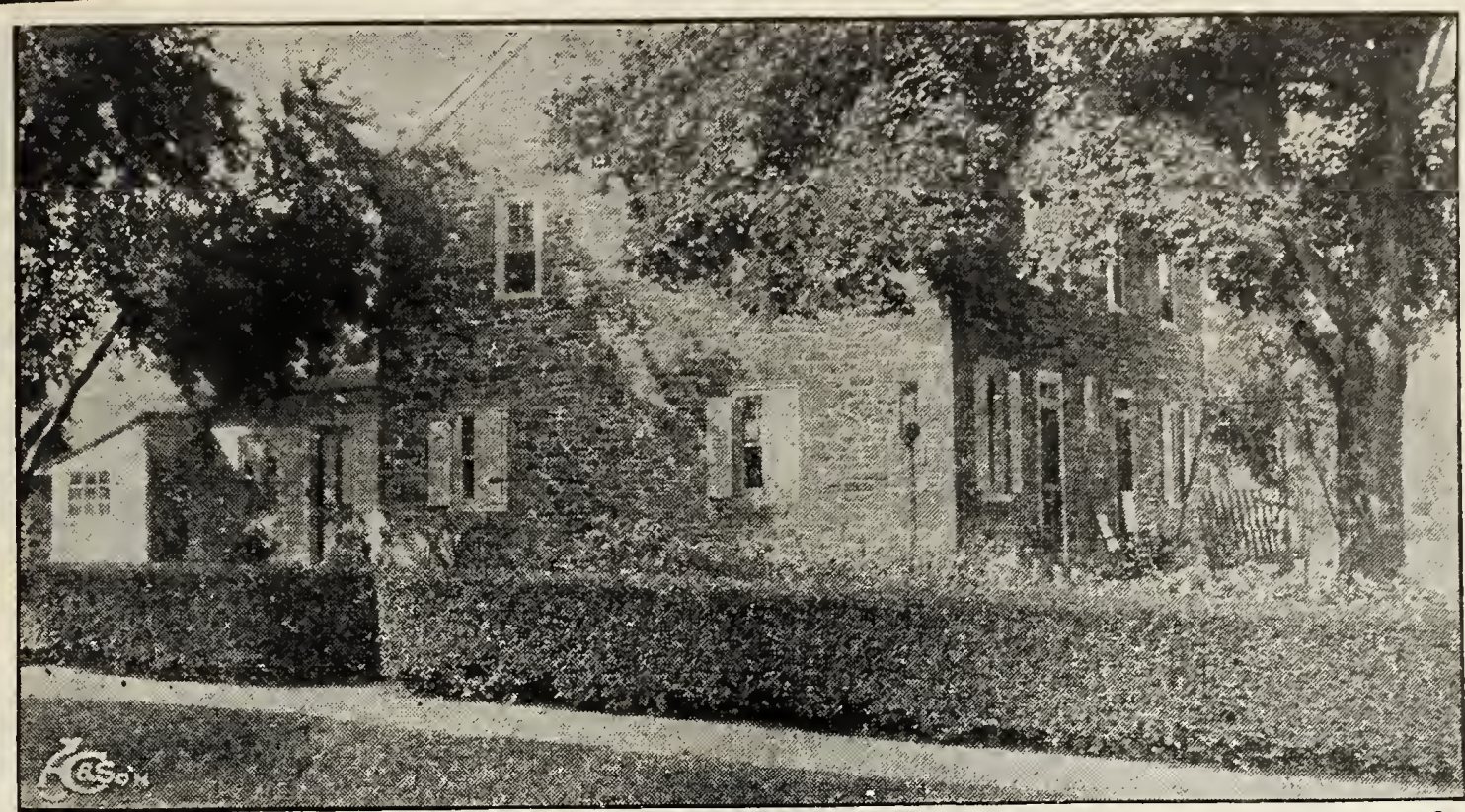

This attractive photograph was sent to us by one of our customers, unsolicited by This attractive "I received 900 California Privet plants from you, and the hedge which they form is certainly fine. I will enclose cards showing hedge and house. If you can use them, you are welcome to them. I am well pleased with the hedge. It has grown $2 \frac{1}{2}$ feet wide and $2 \frac{1}{2}$ feet high in 4 years."

JOHN W. G. YOUNG, PA.

\section{Collins California Privet}

What is Collins California Privet? It is a strong, healthy plant with glossy green leaves, and when mature it bears small clusters of white flowers.

For what are the plants used? For hedges, for screens, for planting between the lawn and the street, for clumps on the lawn, for arches, for flanking walk entrances, and for one hundred other purposes.

Do you just plant them? Yes, that's all; set them out in a single row (or if you prefer in a double row) six inches apart in the row, and if in double row plant them staggered. This requires two to the foot, or 100 plants for 50 feet. Tramp the earth well about the roots and trim the hedge off even on top.

Do they get a disease? No. Nothing attacks these rugged plants. Neither insects nor disease find lodging here.

Are Collins Privet Plants healthy? Yes. They are grown on strong, Jersey soil, we keep them well farmed, which kills the weeds and makes the plants grow fast. and we give them liberal helpings of fertilizer and manure. That ought to make them healthy and happy, and they are.

So popular has this California Privet Hedging become that we venture to say that there is more of it planted each year about the properties in the eastern section of the United States than all other varieties of hedging material put together.

THE UNIVERSITY OF THE STATE OF NEW YORK

THE STATE DEPARTMENT OF EDUCATION COMPULSORY ATTENDAKCR DIVIAION

Worcester, II.Y.

A. J. Collins \& Sons, Inc.,

Loorestown, N. J.

Cantlemen:

I was reading in your catalogue in regard to the hedgo of California Privet of John G. Young. I can beat it. I bought of you last spring same Privet and set it sometine in April, cutting it down to six inches. In June I cut off one half of the new growth. It stands today 31 inches high and 22 inches wide.

I nover saw anything grow as it does, but I am caltivating it and giving it the best of care.

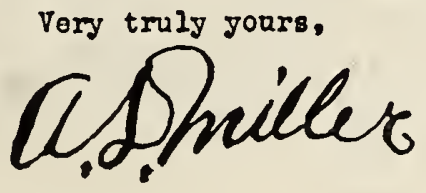

REDUCED PRICES

$100 \quad 1000$

12 to 18 in..... $\$ 3.75 \$ 35.00$ The

18 to 24 in.... $5.75 \quad 55.00$

2 to $3 \mathrm{ft} . . . .8 .8 .00 \quad 75.00$

3 to $4 \mathrm{ft} . \ldots . . .10 .50 \quad 100.00$

4 to $5 \mathrm{ft} . \ldots . . .15 .00 \quad 140.00$

5 to $6 \mathrm{ft} . \ldots .20 .00 \quad 190.00$

Plant Collins Privet and Barberry

-in a row in front of your porch or down each side of your walk.

Group them at the walk entrance or on both sides of your front steps.

Plant at the bases of shrubs and trees to hide unsightly bare spaces.

Plant them on the hare side of your house where other plants have failed. 

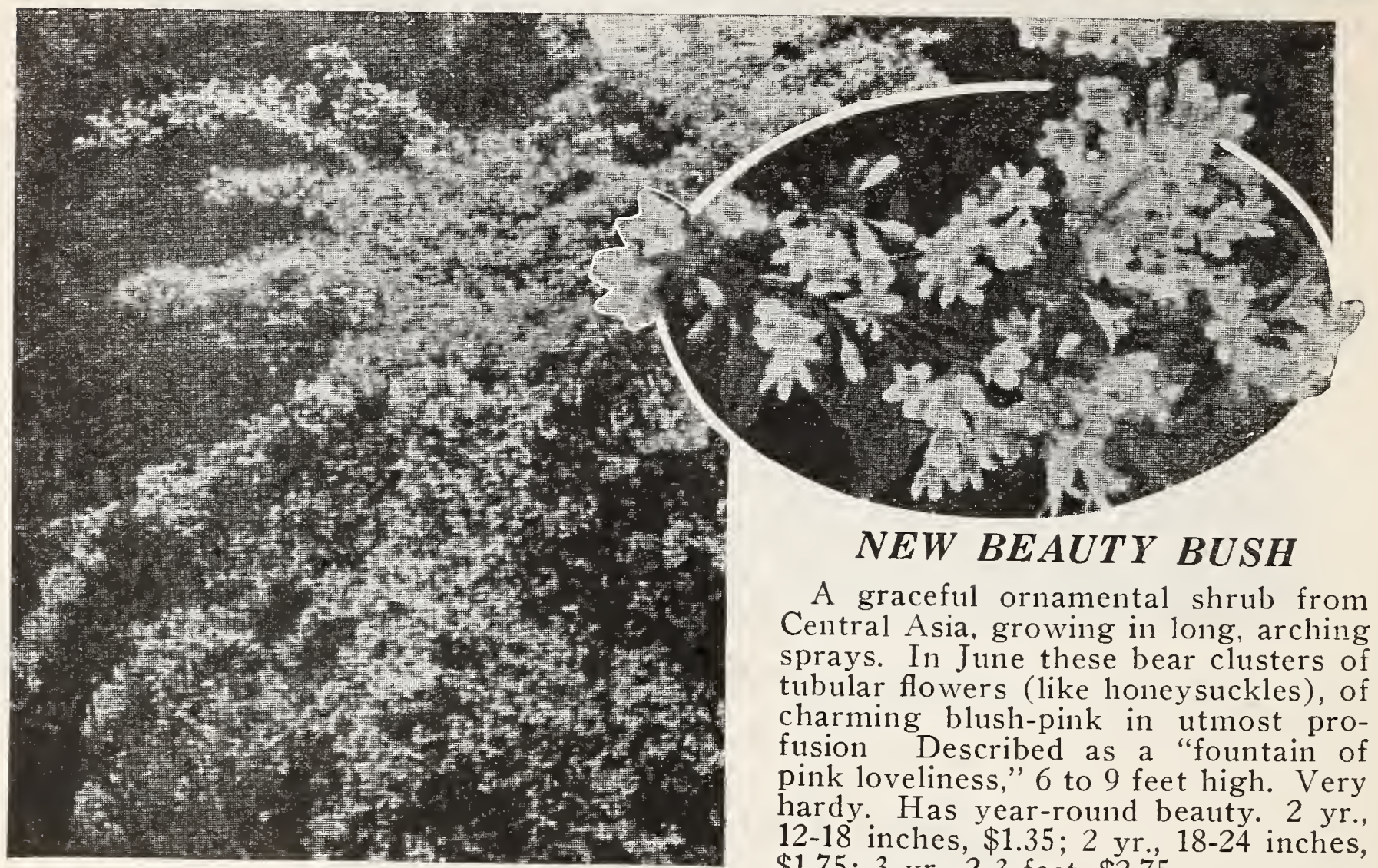

A graceful ornamental shrub from Central Asia, growing in long, arching sprays. In June these bear clusters of tubular flowers (like honeysuckles), of charming blush-pink in utmost profusion Described as a "fountain of pink loveliness," 6 to 9 feet high. Very hardy. Has year-round beauty. 2 yr., $12-18$ inches, $\$ 1.35 ; 2$ yr., $18-24$ inches, $\$ 1.75 ; 3$ yr., $2-3$ feet, $\$ 2.75$.

\section{Collins Flowering Shrubs $\begin{gathered}\text { Give you fowere sand } \\ \text { berrices all year round }\end{gathered}$}

These strong and sturdy flowering plants are always favorites, producing great quantities of blooms and berries of bright colors (many of them are very fragrant), from earliest spring throughout summer and fall. Even through winter charming effects are had with the gay, bright colored berries and twigs that glow under the ice.

Cut the flowers and berries for indoor decoration and enjoy them in vases. So easy to grow and so hardy that they belong on every property. Our plants are bushy, well-developed and will all bloom this year. These letters indicate size finally attained by the Flowering Shrubs: L-Large. M-Medium. S-Small. D-Dwarf.

\section{ALTHEA, or Rose of Sharon}

Tall, columnar bushes, stately and compact, are excellent as a nedge, have flowers like roses all summer- "Rose of Sharon"-red, white, blue, pink. Bush form: 3 yr., 2-3 feet, $55 \mathrm{c}$ each; 5 for $\$ 2.40 ; 12$ for $\$ 5.00$. Tree form: $4-5$ feet, $\$ 1.50$ each.

\section{BARBERRY (Japanese) also New Red-Leaf (See page 20)}

\section{BUTTERFLY SHRUB or Summer Lilac}

BUDDELIA VEITCHIANA. Grows rapidly and produces masses of bloom the tirst season. The blooms, which first appear in July and are continuous until cut down by severe frosts, are a very pleasing shade of violet. Very desirable. Because it is such a heavy producer of delightfully fragrant, beautifully formed flower spikes it wins a place on every property. Everyone loves this shrub-grows so fast, even the first season, bears so many fragrant, handsome flower spikes, lures the butterflies and SPECIAL OFFER. 6 Butterfly always has a crop of flowers ready to cut for the

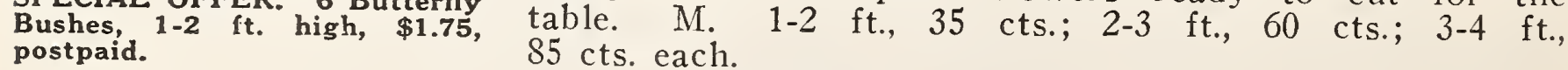

\section{DEUTZIA}

All of the Deutzias are very attractive, ranging in height from low to very tall varieties and covered in spring with myriads of dainty flowers, beautifully formed. CRENATA PINK. Very fine double pink flowers, tinted rosy-white. June. L. [3

PRIDE OF ROCHESTER. Up-right, fast-growing shrub, heavily loaded with beautiful double white flowers, blush tinged. May. L. 2-3 ft., 65 cts. each. 


\section{Collins Dozen Flowering Shrub Offer}

(Shown in color on pages 38 and 39 )

This assortment of choice varieties was made up with the idea of furnishing an ideal group for use as a border planting, as a screen, or to use as a good-looking bed of Shrubs, from which to cut flowers and berries practically any month in the year. Its array of pretty flowers, interesting bright colored foliage, and glistening berries delight all. Berries and flowers of these 12 hardy shrubs shown on pages 38 and 39 and described in detail on pages 22 to 25; except Red Barberry, page 20.

12 Choice Shrubs, good roots, good tops, all to bloom this season, $\$ 2.95$. If desired by parcel post send 25 cts. extra for postage and special packing.

HONEYSUCKLE BUSH

(For Honeysuckle Vines see page 19)

LONICERA TARTARICA. These very desirable free-flowering shrubs have an erect, bushy habit of growth, very ornamental with their fruit of brilliant scarlet in autumn and fragrant myriads of blossoms in June. L. 18-24 in., 45 cts. each. 2-3 ft., 65 cts. each.

\section{HYDRANGEA}

No more popular shrubs are available today than the well-known Hydrangea, appreciated by all who know them.

ARBORESCENS. HILLS OF SNOW. These sturdy bushes are laden with flat flower heads of pure white from June to September; fine green foliage. Plants do well in sun or shade. M. 2-yr. heavy, $1 \mathrm{r} / 2-2 \mathrm{ft}$., $65 \mathrm{cts}$. each.

OTAKSA. THE FAMOUS BLUE HYDRANGEA seen at the seashore resorts. The immense blue heads are very striking while surrounded by a wealth of rich green foliage-an attractive setting; very popular. Vigorous grower, per-

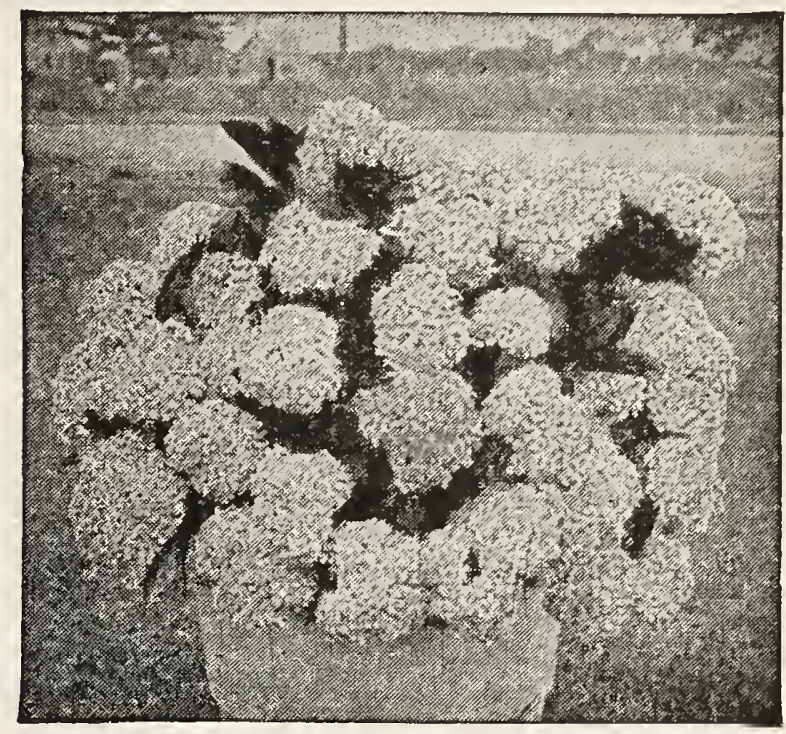

Blue Hydrangea

SPECIAL BLUE HYDRANGEA OFFER. 3 small plants for $\$ 1.25$, postpaid. fectly hardy, preferring partly shaded positions. Greatly used in landscape work for shady spots where nothing else will grow. Immense, attractive blooms continue to flower throughout the whole summer season. S. Size to bloom this year, sturdy plants with many shoots, 90 cts. each; $\$ 9.00$ per dozen.

PANICULATA GRANDIFLORA. PEEGEE. This large, white-flowering Hydrangea is a fine old favorite, undoubtedly the most beautiful of all. Its great panicles or heads (larger than a huge cabbage) of white flowers which change to pink in autumn, hang in long, arching sprays. These may be cut and carried into the house at the approach of winter, where they last many weeks. This plant makes a striking show from August until December. M. [3 Hydrangea "Peegees," 12-18 in., for \$1.25 postpaid.] Bush Form: 2-yr., 18-24 in., 60 cts each; 3-yr., 3-4 ft. (heavy specimen), 90 cts. each.

Tree Form: On upright trunks like small trees. Ornamental. $\$ 1.50$ each; per pair, $\$ 2.75$.

\section{FORSYTHIA (Golden Bells)}

This is the most striking shrub in the early spring. It fairly glows under a wealth of rich yellow flowers that cover the whole bush in April and May before the leaves appear; never fails to call forth exclamations of delight. Use these liberally.

INTERMEDIA. A fine, graceful variety with erect, arching yellow branches which are loaded with bright orange-yellow flowers before its handsome foliage appears. Has attractive purple leaves in autumn. L.

VIRIDISSIMA. A rapid, strong grower with green branches and very deep yellow flowers. Gives quick effect. M.

All Forsythias, $12-18$ in., $35 \mathrm{cts}$. each, 3 for $95 \mathrm{cts}$, postpaid; $2-3 \mathrm{ft}$., $60 \mathrm{cts}$. each, 3 for $\$ 1.50 ; 3-4 \mathrm{ft} ., 80 \mathrm{cts}$. each. 


\section{INDIAN CURRANT}

SYMPHORICARPOS VULGARIS. This graceful shrub bears quantities of scarlet colored flowers in June which are followed by myriads of small red berries in the fall, the weight of which arches the branches in a graceful form, extensively used in plantings. $M$. $2-3 \mathrm{ft}$., $65 \mathrm{cts}$. each; 3 to $4 \mathrm{ft}$., $\$ 1.00$ each.

\section{JAPAN FLOWERING QUINCE ("Japonica")}

Bushy, handsome shrub, which produces its orange-red flowers early in spring, before the leaves appear, which makes it a very bright spot of color and by far the best red at that early season of the year. M. $11 / 2-2 \mathrm{ft}$., $75 \mathrm{cts}$.

\section{LILAC}

OLD-FASHIONED PURPLE. Strong, vigorous, upright grower with deliciously sweet-scented purple flower clusters. 18-24", $50 \mathrm{cts} ; 3-4 \mathrm{ft}$., $90 \mathrm{cts}$.

OLD-FASHIONED WHITE. Similar to purple. Pure white flower clusters. Very fragrant. 2-3 ft., $\$ 1.00$.

PRESIDENT GREVY. Double. Soft blue.

MARIE LEGRAYE. Single. Excellent, purest white.

SOUV. DE L. SPAETH. Single. Enormous purple violet.

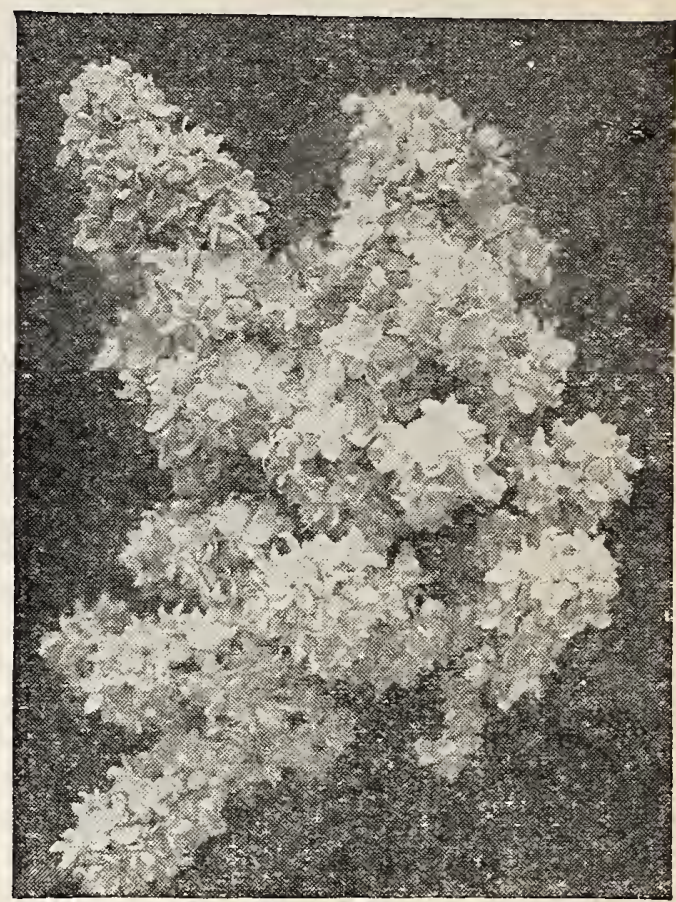

Double Lilac

CHARLES JOLY. Double. Dark velvety purple, reverse of petals silvery.

CHARLES X. Single. Magnificent, lilac-colored clusters tinged violet. Each 90 cts.; or one each of last 5, all fragrant (flowering size), $\$ 3.75$ for all five.

Tree form (new), assorted colors, $3-4 \mathrm{ft}$. (bloom first season), each $\$ 1.75$; per pair, $\$ 3.00$.

\section{MOCK ORANGE (Philadelphus)}

CORONARIUS. A truly fine shrub with the long branches that arch beneath the weight of its deliciously fragrant flowers. Blooms pure white produced in June.
Sweet-scented. L. 2 to $3 \mathrm{ft}$., $65 \mathrm{cts}$; $3-4 \mathrm{ft}$., $95 \mathrm{cts}$.

GORDONIANUS. A very strong grower with large pure white flowers. Fragrant. Blooms June. L. [3 plants, $12-18$ in., for $\$ 1.00$ postpaid.] Each, 2 to $3 \mathrm{ft}$., $65 \mathrm{cts}$.

VIRGINAL. New and unlike any other of the Mock Oranges in size of its very beautiful blooms, which are indeed more fragrant than the old-fashioned sweet Mock Orange; and the beautiful pure white blooms are borne every month through the season, which makes it very desirable. The flowers are produced in great quantity. We consider this bush quite a distinct asset to any shrubbery planting. 2 to $3 \mathrm{ft}$., 3
yr., $95 \mathrm{cts}$. each.

\section{SPIREA}

ANTHONY WATERER. Blooms all summer. A fine, hardy shrub, producing quantities of large, flat clusters of rich, rosy-red flowers in succession. An attractive variety
until fall. D. $12-18$ in., $50 \mathrm{cts}$. $2-3 \mathrm{ft}$., $\$ 1.50$.

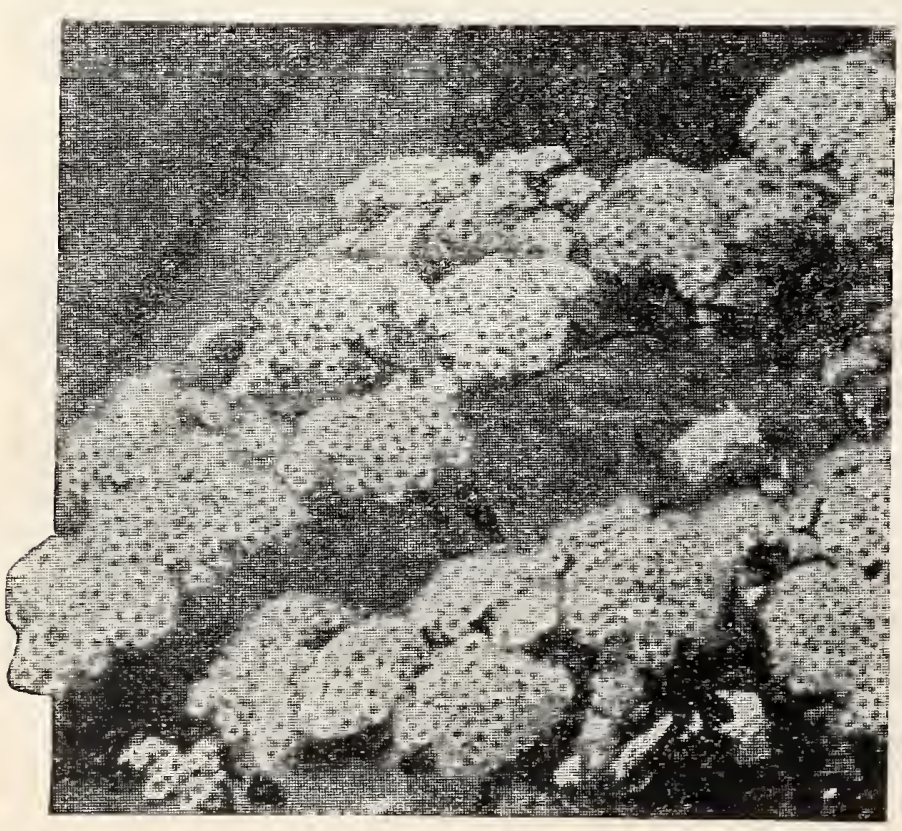

Korean Spirea
BRIDAL WREATH. A very graceful shrub bearing in May great quantities of small double white flowers delicately formed. Very showy. Foliage changes to brilliant colors of orange and red in fall. M. $12-18$ in., $50 \mathrm{c}$.; $2-3 \mathrm{ft}$., $75 \mathrm{c}$; 3-4 ft., $\$ 1.00$.

\section{KOREAN SPIREA}

S. TRICHOCARPA. A fine new introduction which is considered to be one of the very finest of all of the Spireas. It was discovered in Northern Korea, is therefore very hardy. The bush grows some four to six feet tall, resembling an immense dome; in bloom this is covered with rounded clusters of snow-white flowers. Blooms two weeks later than the famous Spirea Van Houtte. Very attractive foliage of glossy green throughout the seasorr. 2 -yr. 12-18 in., \$1.25; 2-yr. 18-24 in., $\$ 1.50$; 3-yr. 2-3 ft., $\$ 2.25$. 


\section{SPIREA-Continued}

THUNBERG. A very graceful shrub with dark leaves, small and mist-like, that softens the plant, giving it an appearance of a billowy veil. Myriads of white flowers cover the plant in April and May. Fine fall coloring. S. 18 to 24 in., 50 cts.

VAN HOUTTE. This is a fine old favorite, bearing snow-white flowers in plumeshape clusters all over the plant in May and June. Pretty singly or in groups. I.

\section{DN SPECIAL PRICES OF S. VAN HOUTTE}

3 plants 1-2 ft. for $80 \mathrm{cts}$. postpaid; $2-3 \mathrm{ft}$., 50 cts., 3 for $\$ 1.10 ; 3-4 \mathrm{ft}$., 75 cts.

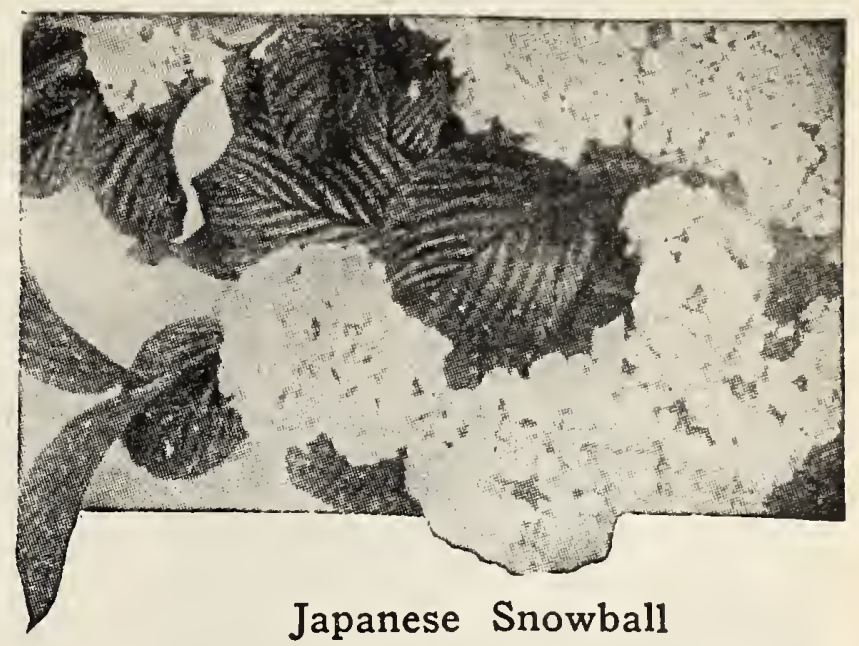

\section{SNOWBALL (Viburnum)}

OPULUS STERILE. OLD-FASHIONED. A desirable shrub with open white flower clusters in May, and myriads of sparkling red berries in fall. 2-3 ft., 85 cts. each.

PLICATUM. JAPAN. The most popular of all the Snowballs, bearing a tight, compact cluster of pure white, snow-ball shaped flowers, very striking in the spring. The handsome green foliage with purple tints gives these flower clusters a rich background of color: M. 18-24 inches, 75 cts.; $2-3 \mathrm{ft}$., $\$ 1.00$.

\section{SNOWBERRY}

SYMPHORICARPOS RACEMOSUS. This shrub gets its name from the large white berries, like cranberries, produced all over the bush in clusters in the fall. Very conspicuous in a shrub planting and a distinct novelty when cut for house use. Attractive pink and white flowers appear on the bushes in July and August. M. 2 to $3 \mathrm{ft}$., $60 \mathrm{cts}$. each.

\section{WEIGELA}

One of the most attractive and desirable of all shrubs. Its large, trumpet-shaped flowers resemble huge honeysuckle flowers and are produced in abundance for many months each year.

CANDIDA. WHITE. Well-shaped pure white flowers in great clusters in June and throughout the summer are produced in profusion. M. 2-3 ft., $75 \mathrm{cts}$. each.

EVA RATHKE. An exceptionally fine shrub, growing erect and bushy, beautiful darkred carmine-lake flowers are borne all through the summer. M. 12 to 18 in., $45 \mathrm{cts}$, 3 for $\$ 1.10 ; 2$ to $3 \mathrm{ft}$., $75 \mathrm{cts}, ; 3$ to $4 \mathrm{ft}$., $\$ 1.00$.

ROSEA. Erect, well-branched bush with fine foliage bearing showy pink flowers profusely in June. Very sweet-scented. M. 12 to 18 in., 35 cts., 3 for 85 cts, postpaid; 2 to $3 \mathrm{ft}$., $60 \mathrm{cts} ., 3$ for $\$ 1.50 ; 3$ to $4 \mathrm{ft}$., $80 \mathrm{cts}$.

\section{Collins Super-Size Shrub Collection}

from 3 to 5 years old. Sturdy, strong, healthy stock; makes a permanent screen now; flowers and berries for every month in the year as follows:

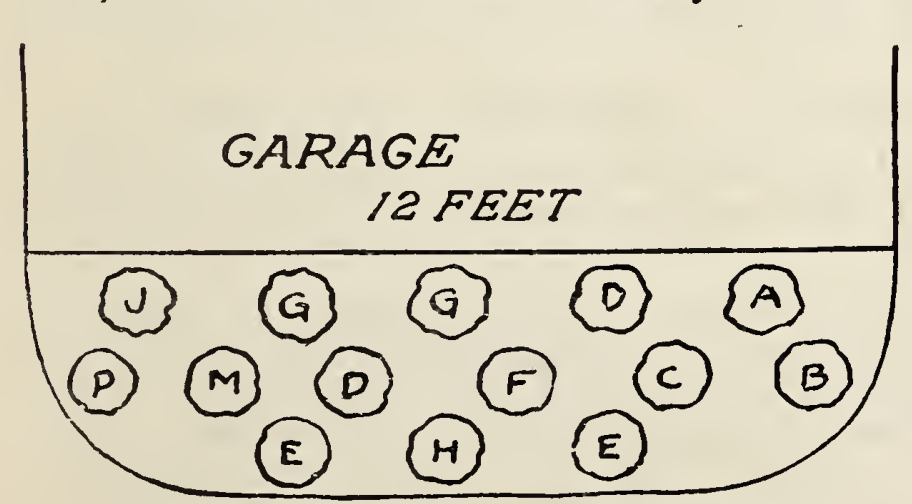

Key

A 1 Deutzia Pride of Rochester (dainty white flowers).

B 1 Snowberry (white berries).

C 1 Hydrangea Peegee (huge white heads turn-

ing pink).

D 2 Butterfly Bush (lilac-violet graceful spike).
E 2 Japan Barberry (sheared specimens, red

F 1 berries).

C Philadelphus (sweet-scented pure white).

G 2 Althea Assorted (rose-like flowers, assorted colors).

H 1 Weigela Rosea (trumpet-shaped pink blooms)

J 1 Forsythia Intermedia (deep golden yelloze flowers).

M 1 Honeysuckle Bush (scarlet berries)

P 1 Spirea Van Houtte (white arching sprays).

\section{$14 \begin{aligned} & \text { Excellent Flowering } \\ & \text { and } \\ & \text { Berry-bearing Shrubs }\end{aligned}$}

(Value, if bought

singly, \$10.25) 


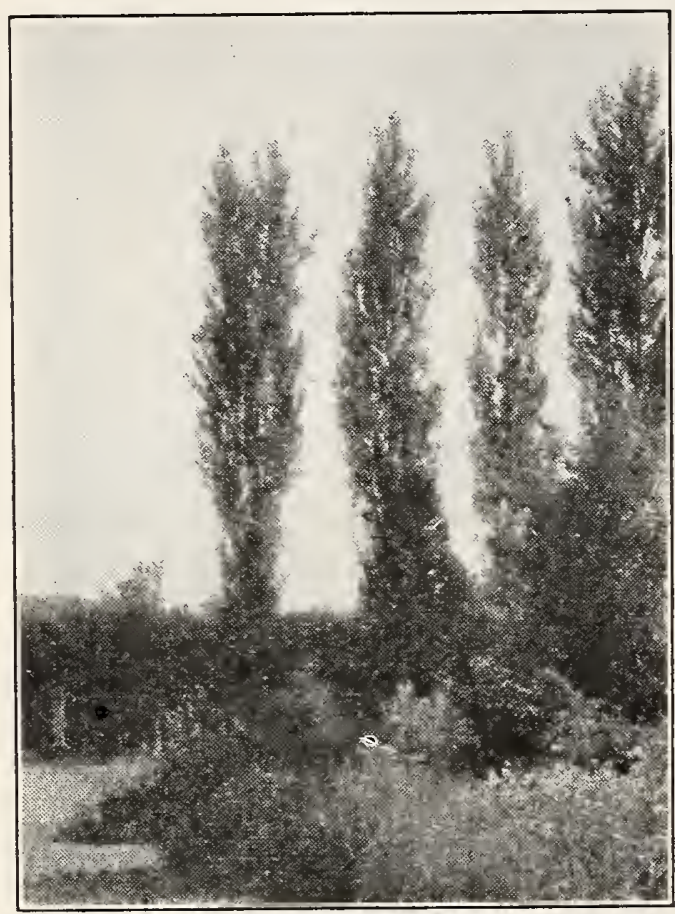

Lombardy Poplar

\section{Collins Shade Trees}

NORWAY MAPLE (Acer Platanoides). A large and handsome tree with a compact round head. Leaves bright green, paler beneath, smooth on both surfaces, changing in Fall to beautiful tones of yellow and gold. A splendid street tree; equally desirable for lawn or landscape. 8 to $10 \mathrm{ft}$., $\$ 3.50 ; 10$ to $12 \mathrm{ft}$., $\$ 5.00$.

SUGAR MAPLE (Acer Saccharinum). Large, stately, dense tree. Leaves dark green above, pale below, turning in Autumn to brilliant shades of scarlet, orange, and yellow. A quick grower, adaptable to all soils. 8 to $10 \mathrm{ft}$., $\$ 3.25$; 10 to $12 \mathrm{ft}$., $\$ 4.25$.

UMBRELLA TREE (Catalpa Bungei). A dense, rounded-headed bush, grafted high on a straight, upright stem. Very hardy and effective, much used in formal gardens and lawns, having the outlines of the standard bay tree. 5 to $6 \mathrm{ft}$., light heads, $\$ 2.50$; heavy heads, $\$ 3.00$.

RED OR PINK DOGWOOD (Comus Filorida Rubra). Bright green leaves, turn red in Fall. Flowers in Spring shade from pink to red. 2 to $3 \mathrm{ft}$., $\$ 4.25 ; 4$ to $5 \mathrm{ft}$., $\$ 9.50$.

WHITE DOGWOOD (Cormus Florida). One of the most beautiful flowering trees; leaves bright green, turning red or scarlet in the Fall. The flowers borne in Spring are white, very showy, and abundant. Fruit in the fall is bright scarlet. Very satisfactory. $2-3 \mathrm{ft}$., $\$ 1.50 ; 3$ to $4 \mathrm{ft}$., $\$ 2.50 ; 4$ to $5 \mathrm{ft}$., $\$ 3.75 ; 5$ to $6 \mathrm{ft}$., $\$ 4.75$.

WEEPING MULBERRY (Morus Alba Pendula). A beautiful weeping, drooping tree; ornamental; bears fruit. Long and slender branches. Light, $\$ 2.75$; heavy, $\$ 3.75$.

WHITE BIRCH (Betula Alba). Prized for its showy white bark. Symmetrical, wellshaped tree. Excellent with tall evergreens in the background. 5 to $6 \mathrm{ft}$. $\$ 2.00$.

WEEPING WILLOW (Sali.r Babylonica). Sweeping billowy mass of foliage. Drooping. Fascinating in a high wind. Fast growers. Relieves bareness from properties.

LOMBARDY POPLAR (Populus Nigra Italica). Stately, tall and picturesque. No tree quite like it for sky-line effect. Quick groiver. Excellent for screening purposes.
PRICES OF WILLOW AND POPLAR TREES

$\begin{array}{crrrr}\text { Size } & \text { Each } & 6 & 12 & 100 \\ 4 \mathrm{ft}^{\prime} & \$ 0.75 & \$ 2.75 & \$ 5 & \$ 40 \\ 6^{\prime}-8^{\prime} & 1.00 & 4.50 & 8 & 60 \\ 8^{\prime}-10^{\prime} & 2.00 & 9.00 & 16 & 120 \\ 10^{\prime}-12^{\prime} & 3.75 & & \end{array}$

JAPANESE WEEPING CHERRY. One of the most striking lawn trees, especially in the spring, when it is covered with a veritable mass of delightful pink flowers, which are borne all over the branches, from the top of the tree clear to the ground. A tree of rare grace and elegance of form. 1 year head to bloom this year. $\$ 4.50$.

DOUBLE RED-FLOWERING ALMOND. Very striking red-flowered tree, bursting into beauty early in the spring, covered with myriads of very deeply colored red flowers, beautifully formed, like little roses. 2 to 3 feet. 85 cts.

DOUBLE WHITE-FLOWERING ALMOND. Pure white flowers. 2 to 3 feet. 85 cts.

FLOWERING CRAB-APPLE. BECHTEL'S. This tree grows very symmetrically, and produces a large quantity of very double and very large flowers of charming rose-pink. 4 to 5 feet. $\$ 1.50$ each.

RED-FLOWERING CRAB-APPLE. (Neidzwetzkyana.) A very remarkable specimen for the lawn. It is red throughout, not only having beautiful red flowers, which arc produced in abundance and which are beautifully formed, but in addition, has bright red branches, red leaves and bears attractive red fruits; 4 to 5 feet. $\$ 1.75$ each.

CUT LEAF WEEPING BIRCH. Exceptionally graceful. Drooping pendulous branches of gleaming white. Beautiful foliage handsomely cut and divided. Perfect as a specimen for any lawn. 3 to 4 feet. $\$ 2.75$ each.

ORIENTAL PLANE OR BUTTONWOOD (Platanus Orientalis). Massive, rugged trees, unaffected by city smoke or insects. Exceptionally fast growers. 8 to $10 \mathrm{ft}$., $\$ 2.50$. 


\section{ARTHUR J. COLLINS \& SONS, INC.}

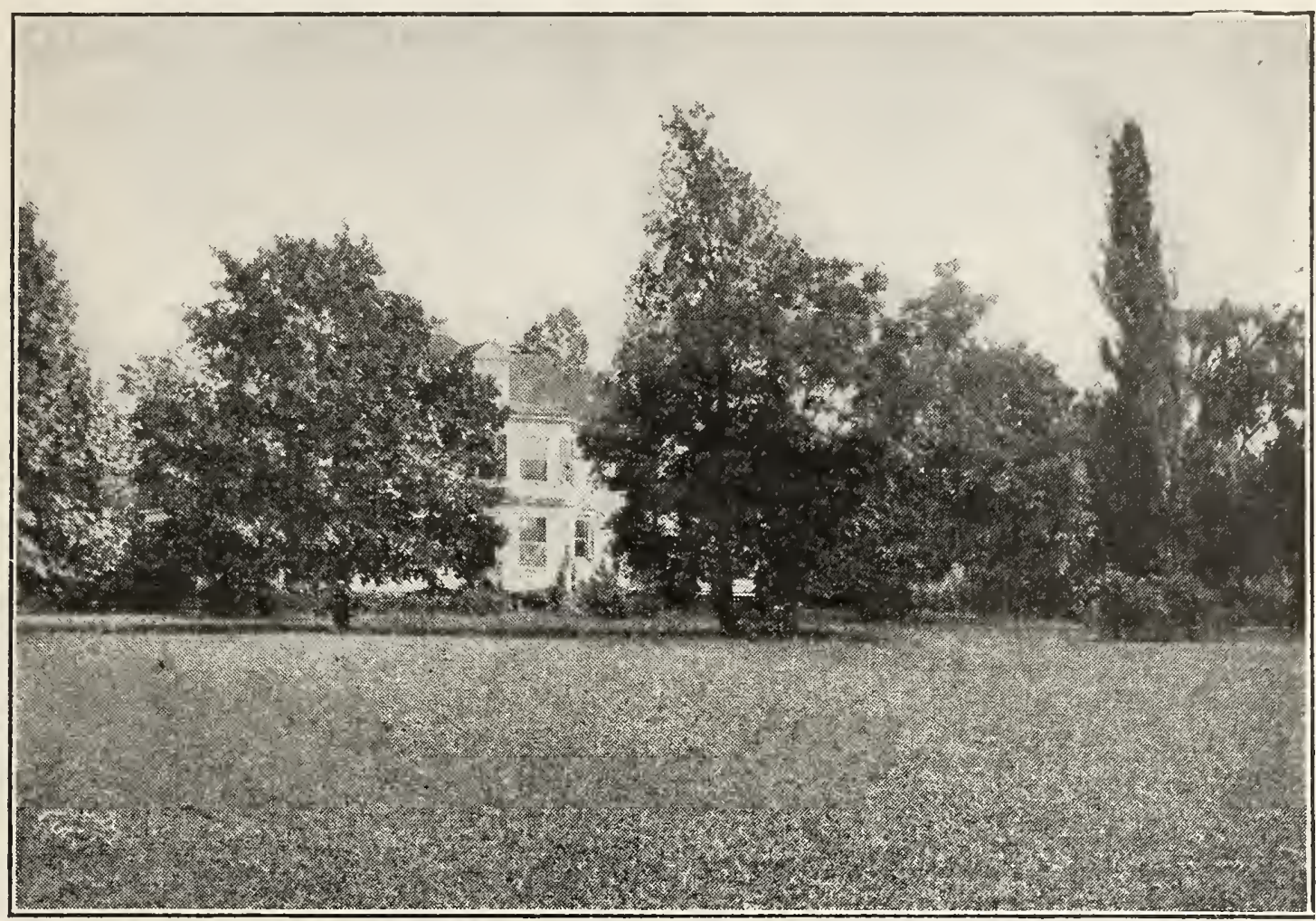

How comfortable and "homey" a house looks, set in a well-clipped lawn

\section{Collins Blended Lawn Grass Seed}

(Sow 1 quart on a plot $10 \times 10$ feet or 100 square feet; 4 quarts on 600 square feet; on peck on 1500 and 1 bushel on 7000 square feet. Sow 6 to 8 bushels per acre to give a thick sod from the start.

(Occasional applications of Sheep Manure through the growing months give color and strength to the new lawn, see page 73.)

999. Collins Velvet Lawn. With this very carefully selected blend of Lawn Grasses we equip you with an ideal mixture to build a fine lawn. Every variety of Grass in it has its special use. There are deep-rooted varieties, spreading ones, tall-growing and dwarf varieties, also those with a rich bright green color, and fine blades. All the kinds unite to form a fine thick tuft of velvety texture, which we unqualifiedly recommend. For prices, see below.

1000. Collins Evergreen Lawn Grass. This is an excellent mixture for new ground and for renovating old lawns. It consists of a carefully blended combination of the best short-growing, fine-bladed grasses, selected from foreign and native stocks. It will produce a permanent sod in a few weeks. It contains a small amount of White Dutch Clover which adds greatly to the appearance of the turf. Blended from varieties that are deep-rooted and best adapted to the various climatic conditions of America. For prices, see below.

1001. Collins Shady Lawn Grass. This contains a proper blending of varieties of grasses that grow well in shady places. This mixture of seeds produces perfect swards in most densely shaded places where other seeds fail. For prices, see below.

1002. Collins Seashore Lawn Grass. This mixture is composed of those varieties of grass that will thrive in salt air regions, producing a good sod in a few weeks, even at the shore. For prices, see below.

Clover, Collins Fancy White, I/2 1b., 60 cts.; per 1b., $\$ 1.10$, postpaid.

\section{SOW COLLINS LAWN GRASS SEED AND HAVE A LUXURIANT GREEN TURF}

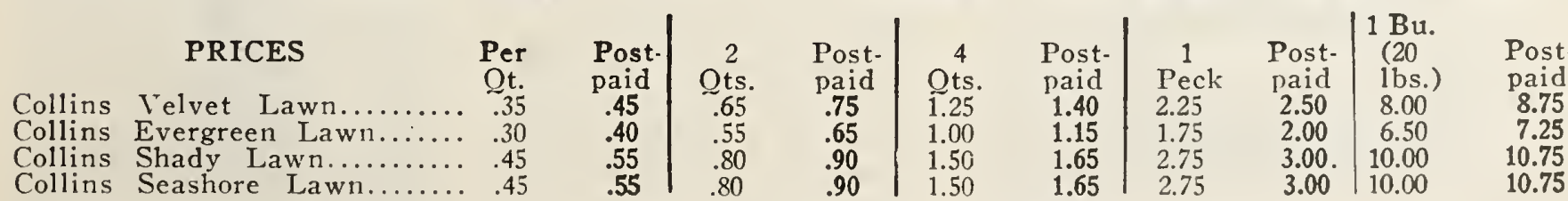




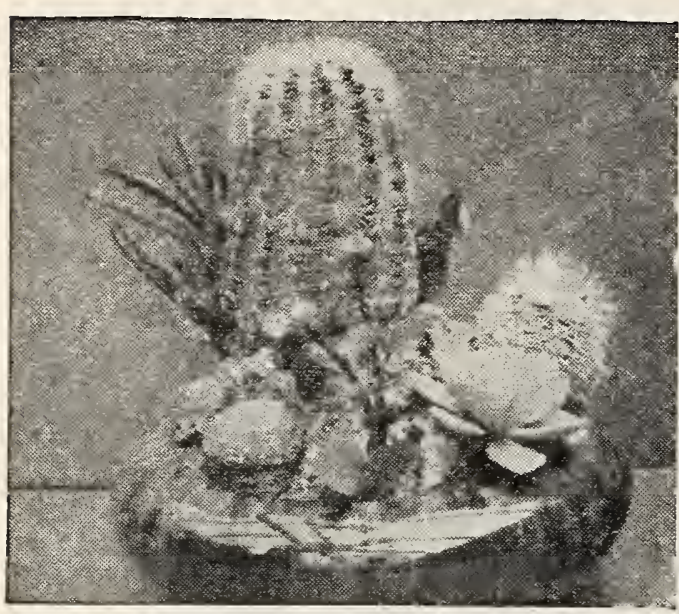

Group Number 1

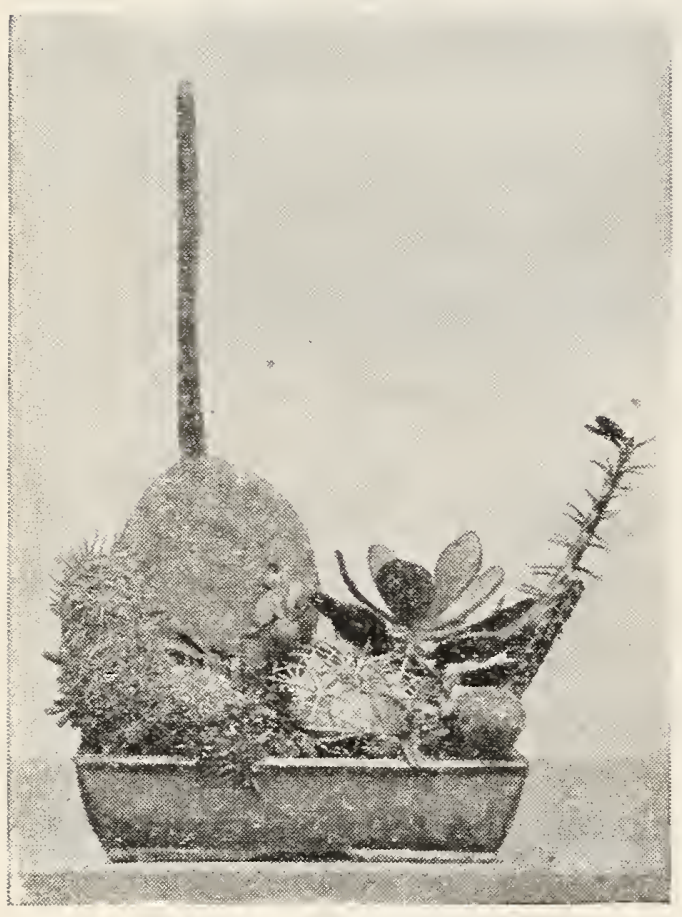

Group Number 2

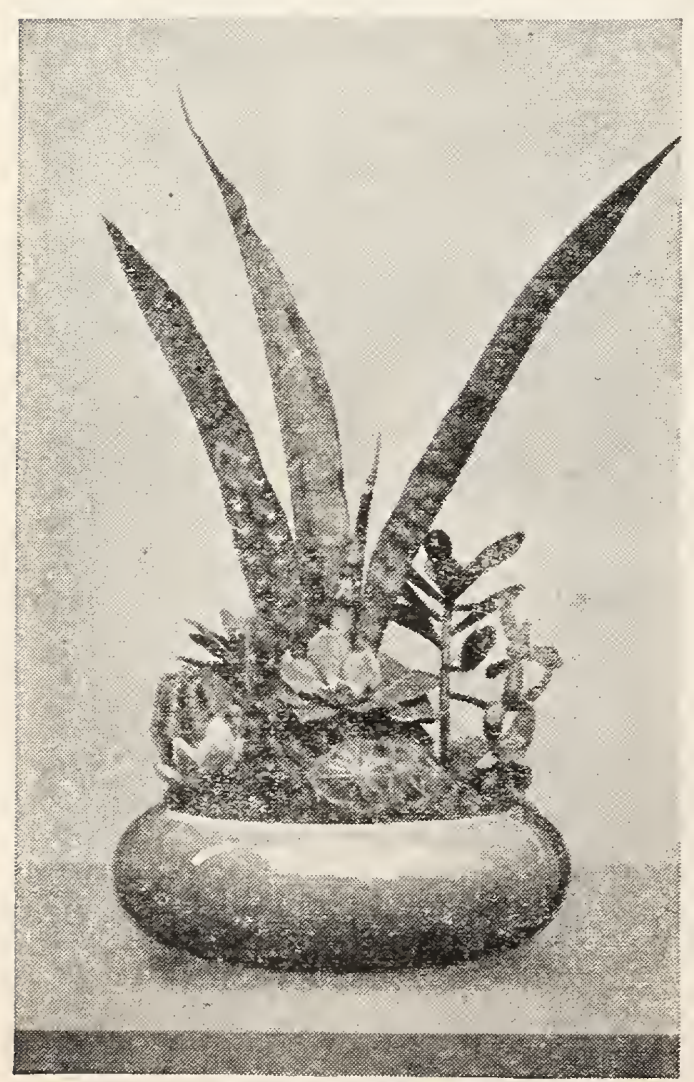

Group Number 3

\section{Rare Cactus Plants}

\section{(Blooming Plants, 5 to 35 years old)}

From the collection of the foremost cactus expert of the United States, a man who has devoted 50 years to cactus culture, we are able to offer these interesting plants-ideal for people with little garden space, for cactus thrives in sunlight on a window sill.

Many of the varieties in this collection have been secured only by long and difficult expeditions in the wildest desert country.

From these many varieties he has made up fascinating collections similar to those illustrated here. No two are ever alike, but each is assembled into a harmonious unit of hardy little plants which come from all over the cactus world, in every conceivable shade of green, gray-green, purple-green, and olivegreen, with bright glowing flowers of red, white, orange, or salmon. As great a variety in colors as in orchids.

Their culture is simple. Just add enough water to moisten soil, once a week or whenever it becomes dry. Full sunlight is necessary-and they must have air.

Groups similar to photo of Group number 1 are priced at $\$ 3.00$, including a fancy bowl.

Groups similar to No. 2-our specialty, a Japanese Garden effect-are priced at $\$ 9.00$, including either round or rectangular bowl (approx. 5 in. by 9 in.).

Groups similar to No. 3 are priced at $\$ 6.00$, including the fancy bowl (approx. 61/2 in. in diameter.)

Lack of space prevents illustrating our special offers at $\$ 1.00, \$ 1.50$, and $\$ 2.00$.

Decide what you wish to pay and we will see that you get full money's worth. We can guarantee satisfaction only because all plants are shipped by express, established in bowls. Beware of cactus by parcel post, which is apt to dry in shipment, and which you must plant and start growing.

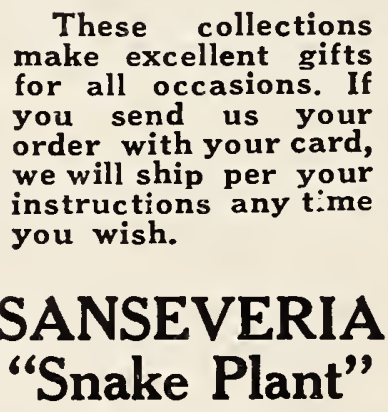

For the first time we offer this unique plant. Commonly known as snake plant. Each plant has several long blades, 15 to 18 in. long and 2 in. wide, producing a peculiarly fascinating effect.

15-18 in. size, green blades, $\$ 2.00$ each.

Variegated ty pe, multi-striped bla de $s$ with rich golden-edged blades (see photo at right) 15 to 18 in., $\$ 3.00$. Prices of larger sizes (either type) on request.

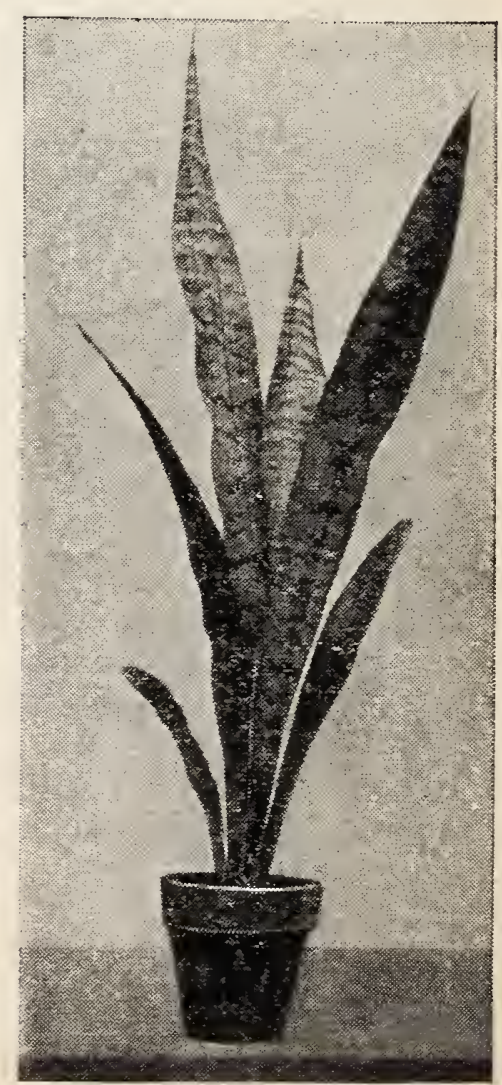

Sanseveria 


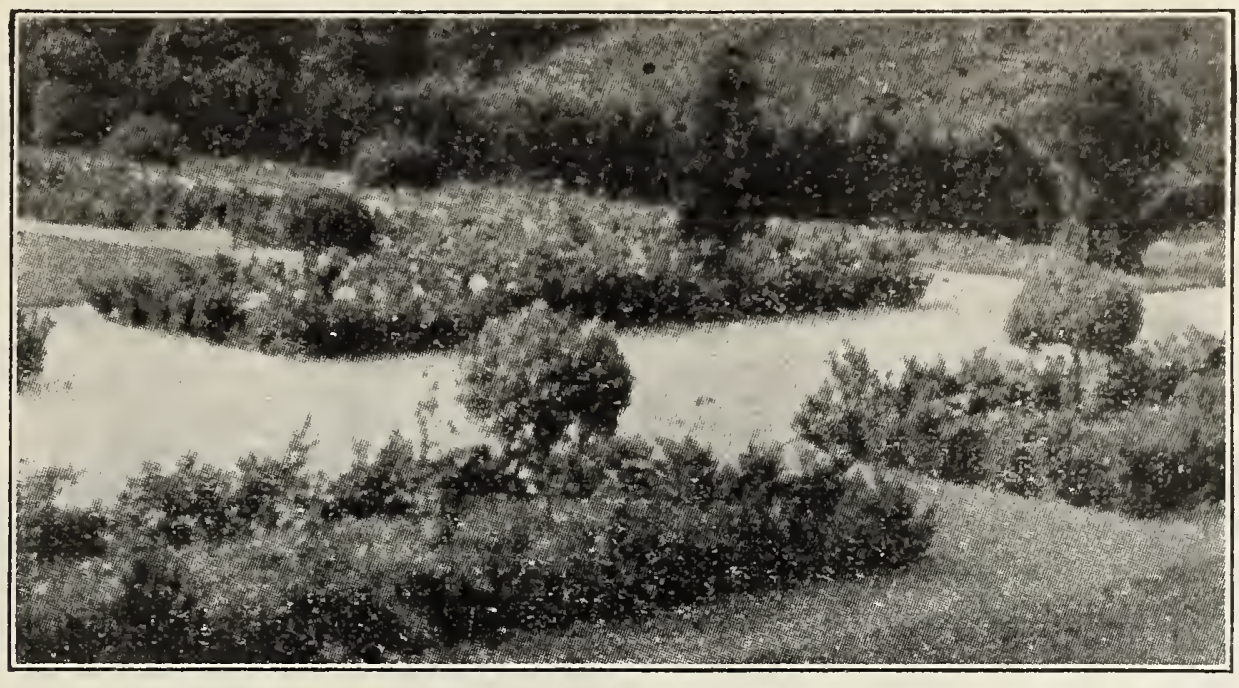

\section{Collins Antique Boxwoods}

Richly fragrant Boxwood, slow-growing and thoroughly old-fashioned, gives the final needed touch wherever used. Excellent for window-boxes and urns in cities; or for neatly edging favorite garden paths, sun-dials or perennial beds. (Note the very low price in quantity.) Fine effect among flowering plants in window-boxes, remaining permanently green after flowers fade. Keeps the edges of flower beds from spreading. BUXUS SUFFRUTICOSA. (Dwarf Boxwood.) This is the dwarfest form of all, growing extremely slowly and is the best-known of all varieties. Very pungent.

Pleasing rich green.

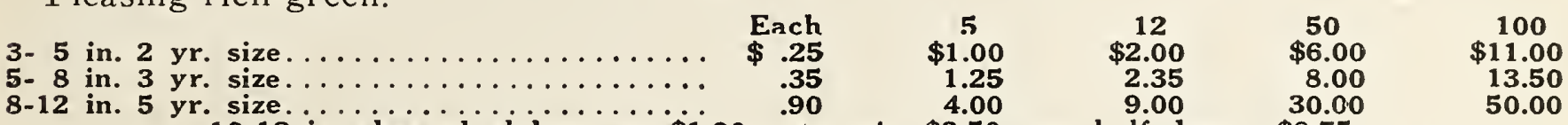
$5-8$ in. 3 yr. size $\ldots \ldots \ldots \ldots \ldots \ldots \ldots \ldots \ldots \ldots \ldots \ldots \ldots \ldots$
$8-12$ in. 5 yr. size. .35

$10-12$ in. sheared globes, ea., $\$ 1.90$; per pair, $\$ 3.50$; per half dozen, $\$ 8.75$.

$1 \frac{1}{2} \mathrm{ft}$. light specimens, ea., $\$ 2.50$; per pair, $\$ 4.50$. $1 \frac{1}{2}-2 \mathrm{ft}$. heavy, ea., $\$ 4.00$; per pair, $\$ 7.50$.

\section{AZALEA}

HINODIGIRI. (Fiery red.) Well-known favorites. These very attractive bushes, quite dwarf, burst into a fiery red mass of bloom in May-the color actually glows, and with evergreens as a background, the setting is perfect. Compact, bushy plants that always remain dwarf. (Size to bloom this year) $10-12$ inches $\$ 2.50$; two for $\$ 4.25$.

Seedlings. In this group of Azaleas we" offer a selected strain of unnamed seedlings of soft, delicate colors ranging from light yellow to deep orange and salmon-pink. Any shade of these colors is most unusual. Excellent in an evergreen planting, singly or in clusters. All colors blend beautifully. 1 to 2 feet (to bloom this year) $\$ 4.00$ : two for $\$ 7.75$.

\section{RARE JAPANESE MAPLES}

Much prized dwarf, bushy plants covered with bright red leaves all season.

These well-known favorites have been exceedingly rare since the importations from abroad have been cut off several years ago. Slowly we are building up a small surplus of these much-prized specimens and we can offer for sale a few of each size as follows: $15-18$ in., $\$ 7.50$ each; $\$ 14.00$ per matched pair; $1 \mathrm{r} / 2-2$ ft., $\$ 10.00$ each; $\$ 19.00$ per matched pair; $2-2 \mathrm{r} / 2 \mathrm{ft}$., $\$ 12.50 \mathrm{each} ; \$ 23.50$ per matched pair.

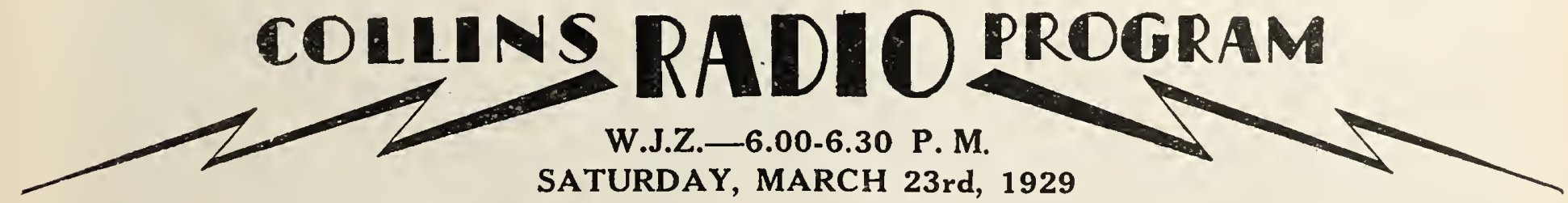

Mighty Like a Rose-Opening Theme.

Liebesfreud

Kashmiri Song

Ballet of Roses

Now Sleeps the Crimson Petal (Vocal)

Rose of Algeria
Helpful Talk on Rose Culture

Salut d'Amour

Love's Garden of Roses (Vocal)

'T'oreador et Andalouse

Mighty Like a Rose-Closing Theme

For Radio Program of following week, see page 49 


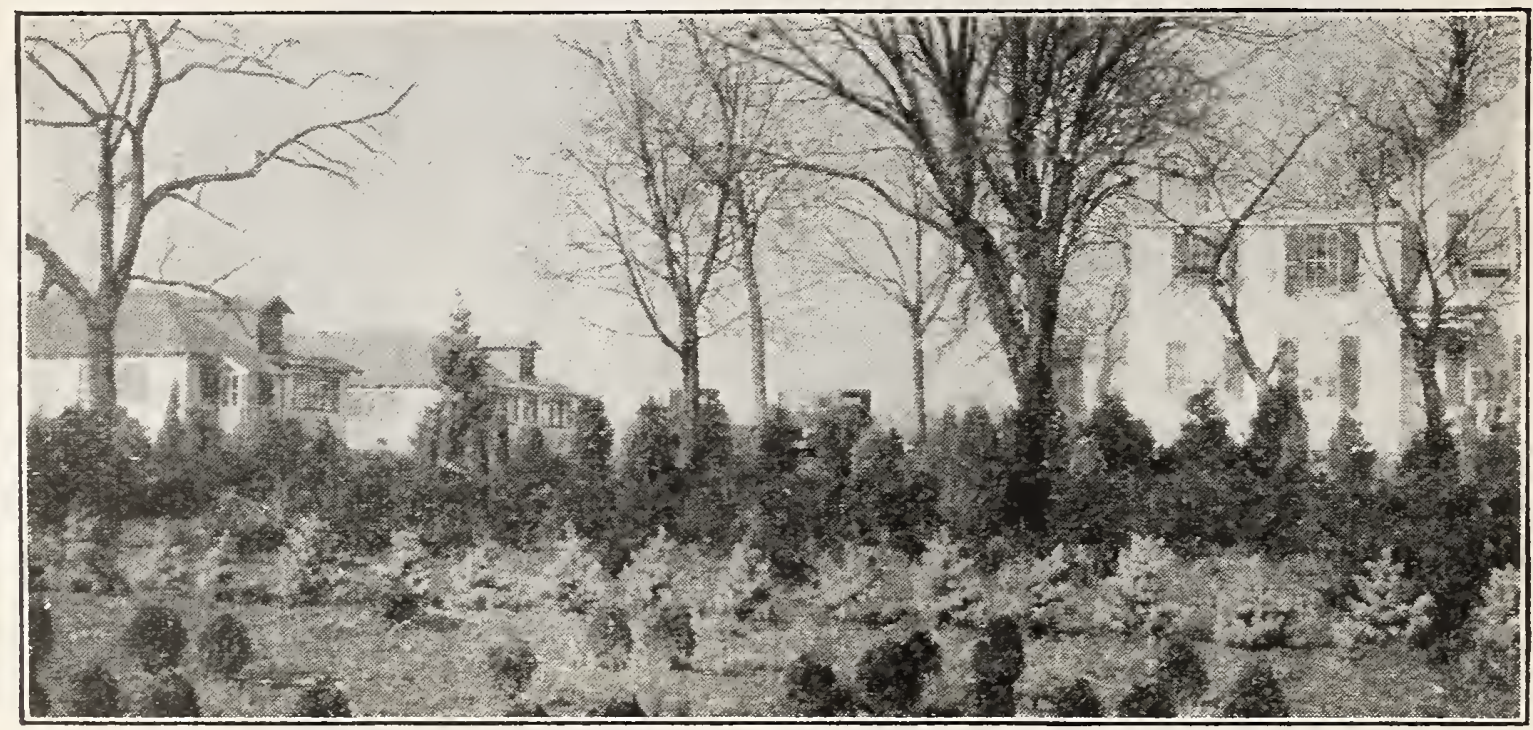

Thousands of evergreens await your selection here-as this corner between our packing sheds (left) and our office building (right) shows.

Note row of Koster's Blue Spruce in foreground, 18" to $24^{\prime \prime}$ specimens, $\$ 15.00$ each

\section{Acres of Collins Evergreens}

We have experimented with sizes, color combinations and different varieties until we have for 1929 the finest collection of evergreens which has ever been offered. It includes all sizes, from 5 inches to 15 feet, at all prices from $87 \mathrm{I} / 2$ cts. to $\$ 75.00$, with colors and shapes ranging from the cone-shaped bright green Cypress, the gray, shaftlike Juniper, the canary-yellow Biota, the deep olive green Yew, the silvery blue Spruce to the round rich orange Arborvita. Space permits us to list here only a few of the hundreds of varieties we are growing.

Many people come to our nurseries each year for their evergreens. From a rough sketch of their property we advise them as to what will give them the best display and they choose the actual plants they like best from the varieties recommended. IVe have these plants tagged, dug and placed on the running board of their cars immediately, or deliver them whenever wanted.

IVe recommend this course as the best, for when we can talk to you personally we are in a better position to help you.

But if you cannot visit us you can have a member of our firm act as your personal buyer. Simply send us a photo and rough sketch of your property with any other data which you think we will need, and tell us approximately how much you desire to spend, as "not over \$25.00," or "not over \$40." From this information we will send you a collection of beautiful plants, personally selected by one who has a real desire to serve you, choosing plants best fitted for your purpose. Every plant guaranteed to please you on arrival.

All of our evergreens are systematically root pruned to promote a healthy growth and owing to the rich garden loam in which they are grown, hold a large ball of earth when moved. Thus, we are able to send them with most of the roots undisturbed in 2 large solid ball of rich soil - the only way which assures you healthy plants, sure to grow.

NOTE-The stock of the $\$ 10$ Evergreen Offer on pages 36 and 37 (see color photo) is sufficiently great that we can supply those who order promptly, no matter where they may be located. These collections are thriving in all sections of the United States and abroad, even in South America. But unfortunately the same condition does not apply

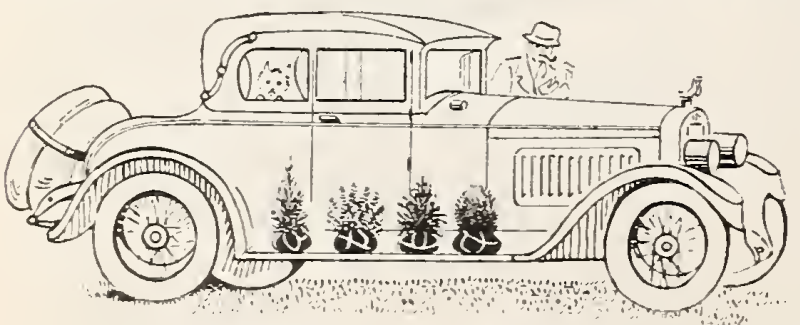
to the other evergreens which follow. On these we are compelled by the relatively limited quantity which we are now growing, especially of the rarer varieties, to restrict our sale to that large demand from the state of New Jersey and that district of Pennsylvania within a 50 mile radius of Moorestown; most of which is within easy motoring and trucking distance. 


\section{ARBORVITA}

PYRAMIDAL ARBORVITA. Tall shaft-like green columns growing upward only (no side branches). Deep green at all seasons. Very hardy, thriving everywhere. Excellent flanking door entrances.

$\begin{array}{rrrrrrr} & & \text { Each } & \text { Per Pair } & 4 & 10 & \\ 2 \text { to } 3 \text { feet, specimens } & \$ 4.00 & \$ 7.75 & \$ 15.00 & \$ 35.00 & \text { Special } \\ 3 \text { to } 4 \text { feet, } & \text { "6 } & 4.75 & \mathbf{9 . 2 5} & 18.00 & 42.50 \text { prices in } \\ 4 \text { to } 5 \text { feet, } & & 6.50 & 12.50 & \mathbf{2 4 . 0 0} & \mathbf{5 5 . 0 0} & 10010 t s\end{array}$

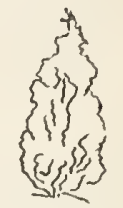

AMERICAN ARBORVITA. Like above, base bushier and broader, tapering upward.

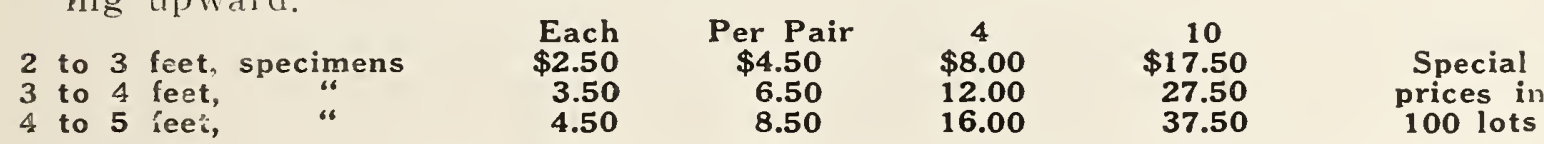

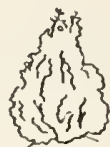

COMPACT. A dense-growing, globe form bush with a very bright lively green foliage. Always formal and attractive. 10-12 in., $\$ 2 ; 1-1 \frac{1}{2} \mathrm{ft} ., \$ 3$.

GEORGE PEABODY. Similar to the American Arborvita except that it is a bright golden-yellow of very deep color. Pyramidal in form, holding its bright hues throughout the winter. 1 foot, $\$ 2.25 ; 1 \mathrm{I} / 2-2 \mathrm{ft}$., $\$ 3.50$.

GLOBE. This forms a low-growing, globe-shaped specimen. Very dwarf. Foliage light green. $1-1 \mathrm{1} / 2 \mathrm{ft} ., \$ 2.50 ; 1 \mathrm{1} / 2-2 \mathrm{ft}$. in height, very bushy, nearly 2 ft. broad, $\$ 3.75$.

RHEINGOLD'S. This is one of the very newest and best Evergreens offered. It is a low-growing, round bush type and there is no other Evergreen which is so colorful. Through the summer it is a yellow or golden hue, which, with the first touch of frost, changes to a glowing deep orange. Every group should contain at least one of these trees for its most unusual coloring. We regret that its present scarcity will not permit us to fill orders for more than two to any one customer. Approximately 1 foot high and 1 foot broad, $\$ 6$. (No more than 2 to any one order.)

SIBERIAN. A bright pyramid with heavy foliage of deep blue-green. Is not a fast grower. $1-1 \frac{1}{2} \mathrm{ft}$., $\$ 2.00 ; 2 \mathrm{1} / 2-3 \mathrm{ft}$., $\$ 6.75$.

\section{BIOTA (Eastern Arborvita)}

BERKMAN'S. This dainty bush is eagerly sought by all who have ever seen it. It grows in flat, vertical sections or layers with sparkling yellow tips. Always quite formal and neat in appearance. Quite dwarf. 15 inch, $\$ 3.25 ; 18$ inch, $\$ 4.25$.

ORIENTAL. A fast-growing beautiful tall green shaft, also growing in flat, vertical layers. Excellent where a column is desired such as either side of a doorway. 3-4 ft., $\$ 5.00 ; 4-5 \mathrm{ft} ., \$ 6.50$.

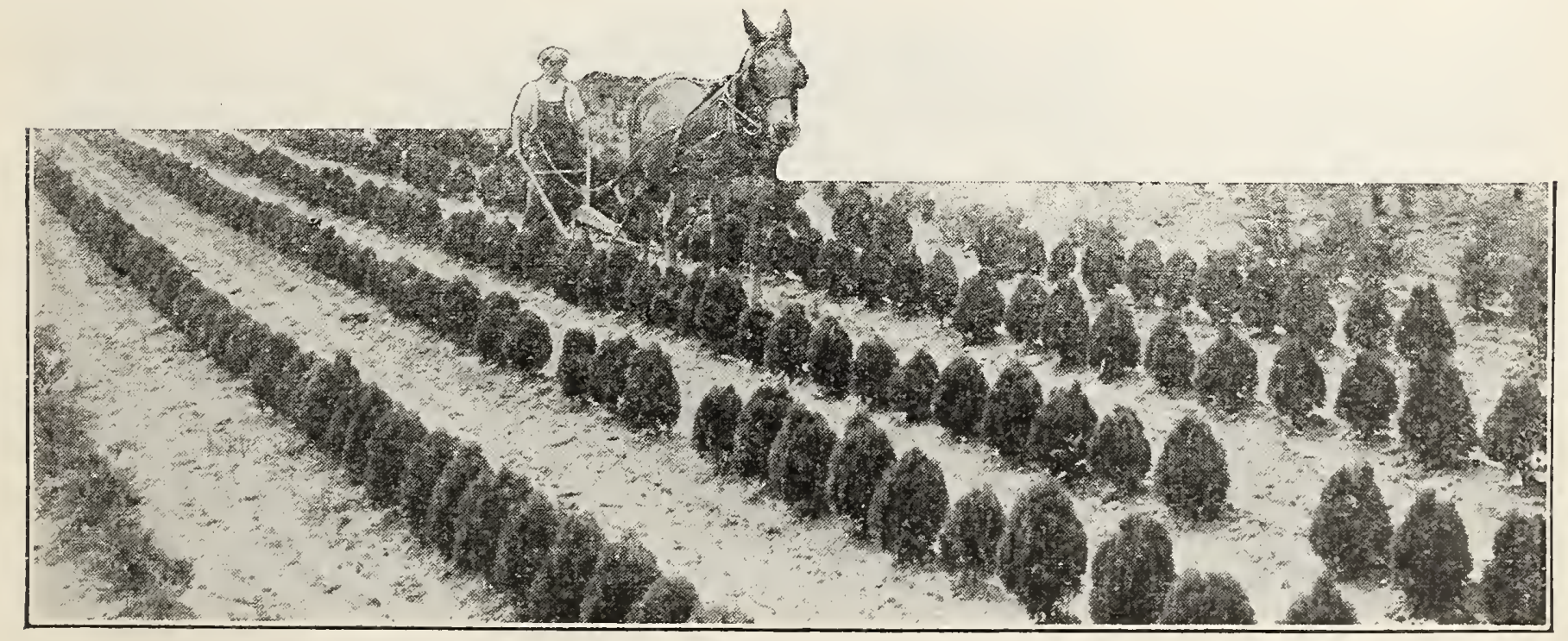

Constant cultivation develops perfect specimens 


\section{CYPRESS}

GOLDEN PEA-FRUIT. Beautiful, shining golden-yellow leaves adorn this graceful bushy Cypress. Fine for the back row in the evergreen bed. Rugged and impressive. $1 \mathrm{1} / 2-2 \mathrm{ft}$., $\$ 2.75 ; 2-2 \mathrm{I} / 2 \mathrm{ft}$., $\$ 3.50 ; 5 \mathrm{ft}$., $\$ 7.50$.

GREEN PEA-FRUIT. Similar to above, except is shining dark-green foliage. $1 \mathrm{r} / 2-2 \mathrm{ft}$., $\$ 2.50 ; 2-21 / 2 \mathrm{ft}$., $\$ 3 ; 4 \mathrm{r} / 2 \mathrm{ft}$., $\$ 6.75$.

GOLDEN PLUME. This charming Cypress has feathery golden leaves which give the tree a soft downy appearance. Also satisfactory for the back row in the evergreen bed. 12 inches, $\$ 2.50 ; 1 \cdot 1 \mathrm{I} / 2 \mathrm{ft}$., $\$ 3.00$.

GREEN PLUME. Similar to above, except is green. 12 inches, $\$ 2.25$; $1-1 \mathrm{I} / 2$ ft., $\$ 2.75 ; 5-6 \mathrm{ft}$., $\$ 7.50$.

GOLD THREAD. Well-named is this Cypress with its drooping branchlets which hang like golden threads all over the outside of the tree. Useful in the foreground as it is a dwarf grower and bright yellow. $1-11 / 2 \mathrm{ft}$. in height and $2-21 / 2 \mathrm{ft}$. wide, $\$ 4.75$.

MOSS. This is a graceful evergreen of dense bushy habit and of bright silvery-blue foliage, which is arranged in spirals. The tree is soft and feathery to the touch. It brings a fresh color note into the beds. Specimens wide and bushy. $1 \mathrm{r} / 2-2 \mathrm{ft} ., \$ 3.50 ; 2-2 \mathrm{r} / 2 \mathrm{ft}$., $\$ 4.50$.

\section{HEMLOCK}

CANADIAN. One of our finest Evergreens, forming, when not trimmed, a slender, open, fast-growing evergreen, but if trimmed, a bushy green, fuzzy ball. Most attractive and extremely hardy. Has many uses; excellent as a formal lawn tree or for keeping clipped in the evergreen bed, or for use as a hedge at the side of the property. $1-1 \mathrm{1} / 2 \mathrm{ft} ., \$ 2.75 ; 2-21 / 2 \mathrm{ft}$., $\$ 4.75,2$ for $\$ 8.00$.

\section{CRYPTOMERIA}

JAPANESE CEDAR. A Japanese Evergreen of tall, slender pyramidal form. Foliage of fresh light-green set closely along the branches. Excellent as columns to frame the entrance. $4-5 \mathrm{ft}$., $\$ 12.50$.
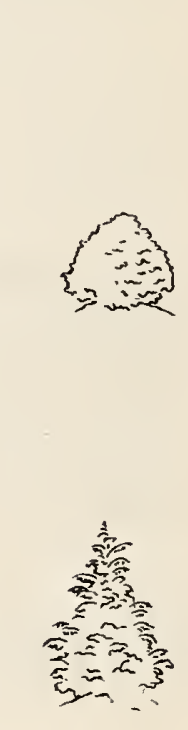

Noderate shearing)

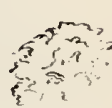

shearing)
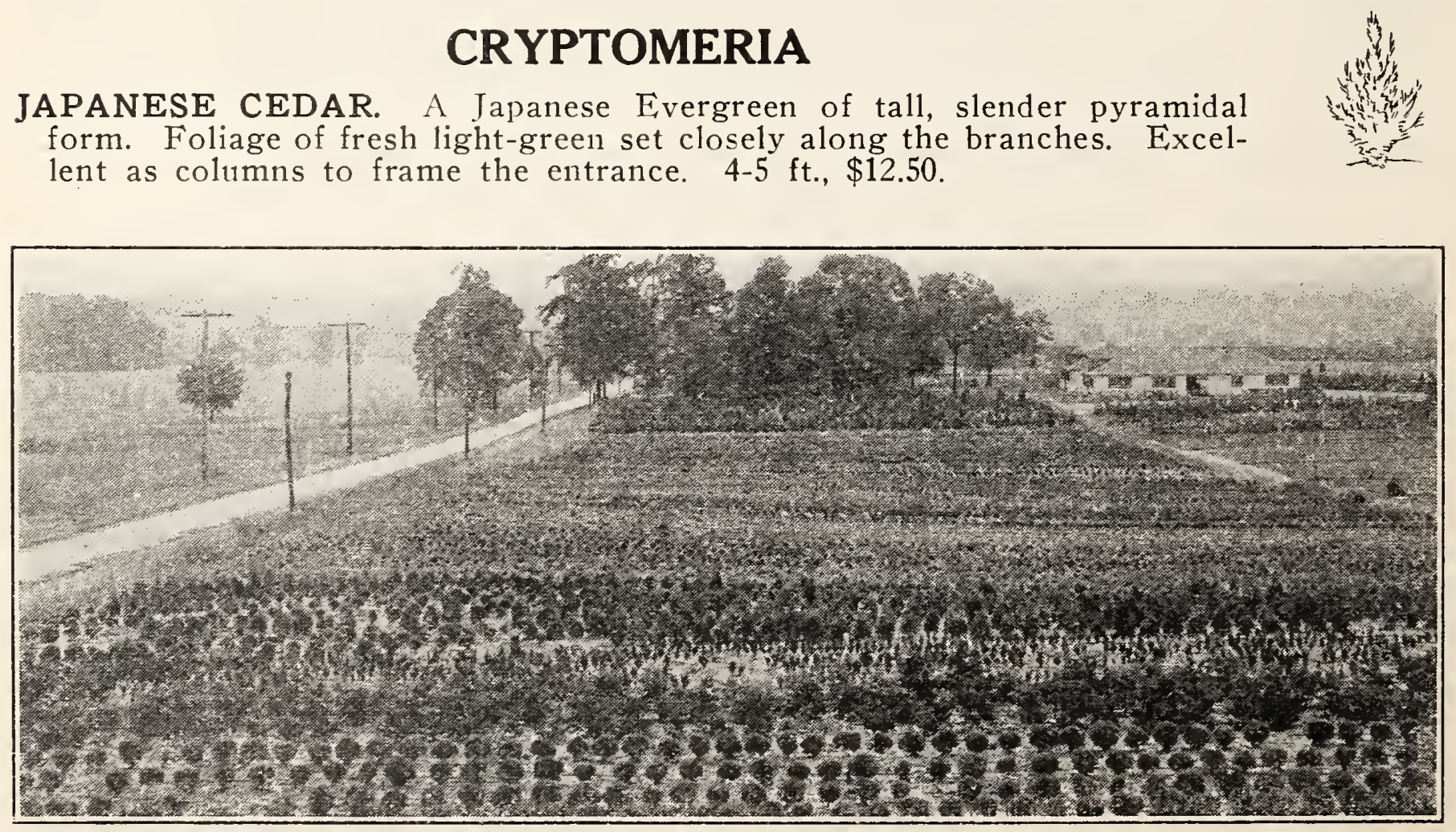

A fine young block, ready next year 


\section{JUNIPER}

COLUMNAR. One of the newer leading Evergreens. It forms a grayblue shaft of color. Rugged, hardy and a most satisfactory tree. 3-3 $1 / 2$ $\mathrm{ft}$., $\$ 5.75 ; 3 \mathrm{1} / 2-4 \mathrm{ft}$., $\$ 6.75$.

IRISH. A densely foliaged gray-green Juniper. One of the most formal of all of our Evergreens when clipped, forming a perfect outline. In the spring the new leaflets of bright green make a marvelous pattern. 1 $1 / 2-2$ $\mathrm{ft}$., $\$ 2.50 ; 2-2 \mathrm{I} / 2 \mathrm{ft}$., $\$ 4.00 ; 2 \mathrm{I} / 2-3 \mathrm{ft}$., $\$ 5.00 ; 3-3 \mathrm{r} / 2 \mathrm{ft}$., $\$ 6.00$.

GREEK. Grows like a little cone, never needs trimming. It is very dense and all of the upward growing shoots taper to one evenly formed tip at the top, as neatly made as if fashioned from a pattern. Deep gray-blue. Most useful and formal. Excellent for tubs, window boxes or the front 23 the evergreen beds or to form markers along the walk. 15 inches, " $"<.75$; 18 inches, $\$ 3.25 ; 30$ inches, $\$ 6.50$, or per pair matched, $\$ 12.00$.

MEYER'S. Recently discovered in China and offered this year for the first time. It is similar in color to the Greek Juniper, though somewhat deeper blue. Its branches are gracefully upcurving, tightly clothed throughout with a rich cloak of deep dark-blue foliage. Perfect specimens, 2 feet high, $\$ 10.00$.

PFITZER'S. A grafted evergreen which grows upward and outward, with a graceful droop at the tips. It is impossible to describe its color accurately because of its many shadings, but it has the appearance of deep rich green with traces of blue and gray shadows. Makes a noble appearance. 1 foot high and nearly 2 feet spread, $\$ 3.50$; per pair, $\$ 6.75 ; 11 / 2-2$ ft. by nearly 3 foot spread, $\$ 4.75$; per pair, $\$ 9$; handsome specimens 3 feet high and 5 feet across $\$ 12.50$ each; per pair, $\$ 25.00$.

SAVIN. A rich vivid green similar to Pfitzer's, growing upward and outward with the leaves held very closely to the limbs. Very young plants make an interesting display when used in window boxes. Exceptionally valuable for the front of the evergreen bed. $1-1 / 2 \mathrm{ft}$., $\$ 2.25 ; 1 \mathrm{1} / 2-2 \mathrm{ft}$., $\$ 2.75$.

VARIEGATED. Similar to the Greek, but has white tips occasionally showing in it, which introduces an odd distinctive color note into an evergreen planting. Very rugged, sturdy grower. 15 inches, $\$ 2.50 ; 18$ inches, $\$ 3.00$.

\section{SPRUCES}

DOUGLAS BLUE. A straight growing Spruce with somewhat pendulous branches, heavily clothed with needles of steel-blue. Among our very finest Spruces with the color note it introduces. $1 \mathrm{t} / 2-2 \mathrm{ft} ., \$ 2.50 ; 2-2 \mathrm{I} / 2$ ft., $\$ 3.25$.

NORWAY. One of the best known and finest of the rich green Spruces. The smaller sizes seem to be made to order for window boxes and Christmas trees. A slightly larger size gives a rich green color to the evergreen bed and makes handsome appearance when used out in the open lawn. One trimming a year keeps it very bushy and compact. Xmas tree size $1-1 \mathrm{1} / 2 \mathrm{ft}$., $\$ 1.00$ matched pair, $\$ 1.75 ; 1 \mathrm{1} / 2-2 \mathrm{ft}$., $\$ 1.50$; matched pair, $\$ 2.75$; $2-2 \mathrm{I} / 2 \mathrm{ft} ., \$ 2.00$; matched pair, $\$ 3.75: 2 \mathrm{1} / 2-3 \mathrm{ft}$., $\$ 5.75$ each.

\section{YEW}

JAPANESE SPREADING. This very attractive variety grows upward and outward making a bright spreading specimen of deepest olive-green. The limbs are never bare, being thickly clothed with quantities of beautifully formed meedles. As a surprise in Autumn many specimens bear quantities of fleshy-red berries. $1 \frac{1}{2}-2$ feet high and 3 foot spread, $\$ 5 ; 2-3$ $\mathrm{ft}$. high and $4 \mathrm{~T} / 2-5 \mathrm{ft}$. spread, $\$ 8.75$.

UPRIGHT, Very similar to the above except that it grows as a small tree with trunk and branches. When trimmed as our specimens are, it forms magnificent posts or pillars (suitable for either side of the doorway) of dark, deep green. This variety is also heavily laden with bright red berries in Autumn. 3 to 4 feet, $\$ 8.75$. 


\section{Only 3 Hours Elapsed}

between these two photographs. But what a difference a little time makes when that time is spent putting in evergreens about the foundations of the home, tying it to the ground, so to speak, and setting off its beauty.

\section{Collins}

\section{Evergreens}

一well grown,

strong rooted, full of vigorwill add to the beauty and value of your property, also.
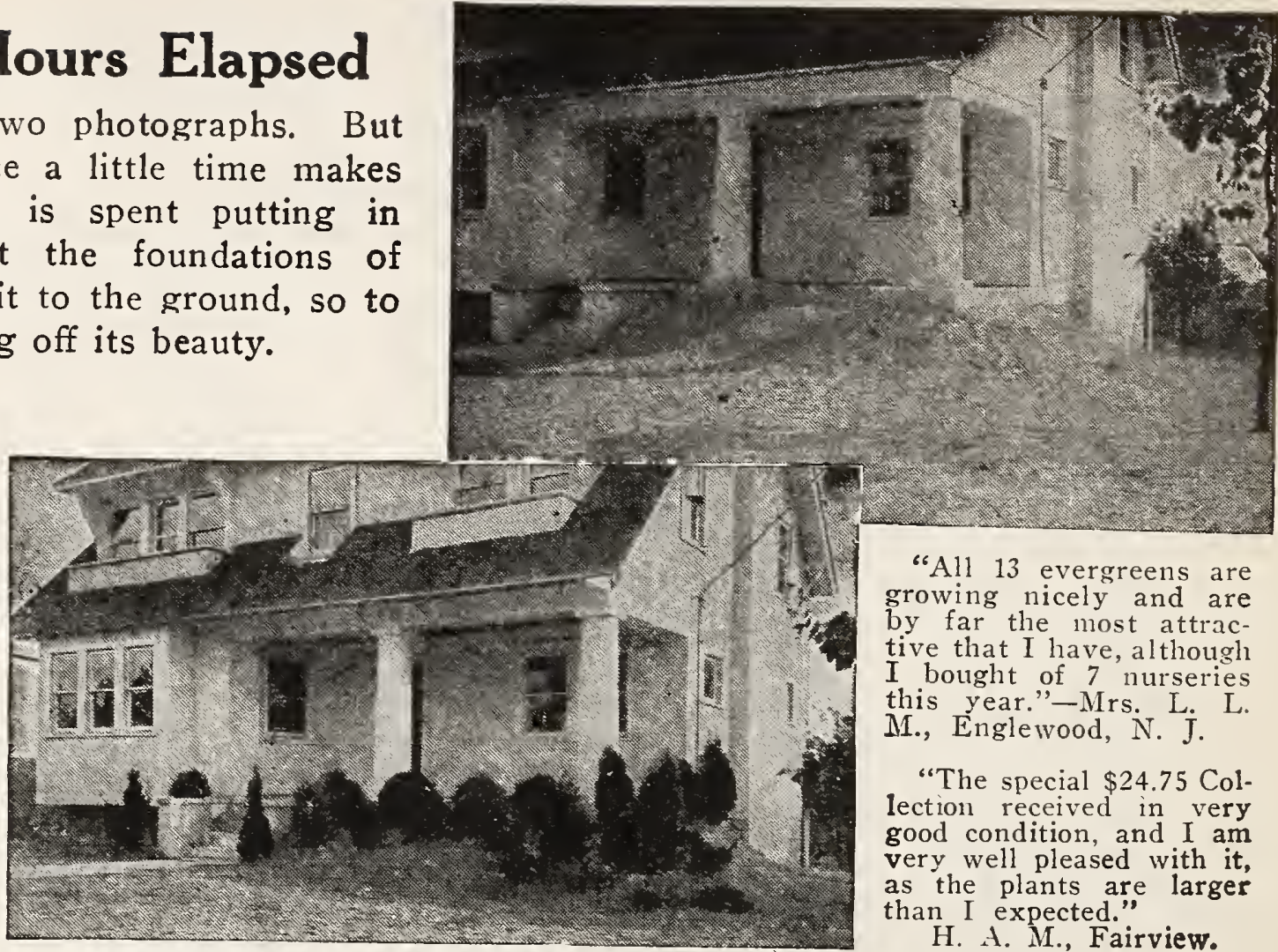

"All 13 evergreens are growing nicely and are by far the most attractive that I have, although I bought of 7 nurseries this year."-Mrs. I. I. M., Englewood, N. J.

"The special $\$ 24.75$ Collection received in very good condition, and I am very well pleased with it, as the plants are larger han I expected."

H. A. M., Fairview.

\section{Collins 1929 Special Landscape Offer}

answers your many questions: "What varieties of evergreens can I secure that will not be duplicated by my neighbors?" "How can I use the newer varieties to harmonize with other evergreens, and with my property?" "How can I make a small expenditure in evergreens add many times its cost to the value of my home?"

Our 1929 Landscape Collection embraces the whole color range in hardy, easy to grow evergreens. It includes varied forms as well as colors. All of these trees are well shaped, carefully grown and healthy, whether they be the dense, rugged specimens used to give background mass or the small bright jewels which bring color and life to the whole planting, when properly placed in the foreground.

You can be sure of proper balance for color, size and habit of growth, because each tree is correctly labeled and a planting key, sent FREE with each collection, makes it ency to place these in proper relative position.

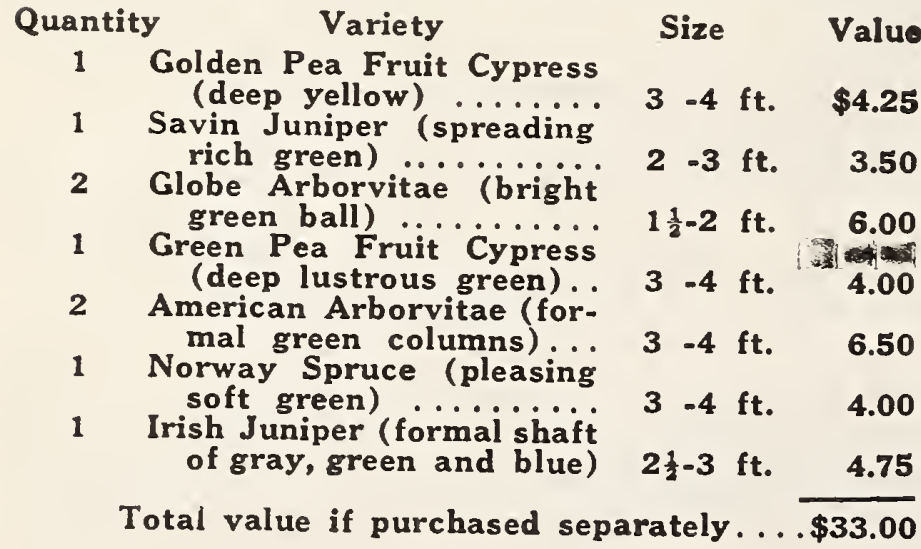

\section{Live Christmas Trees}

(For Your Christmas Dinner Table)

Shapely growing trees which come to you with their roots intact and full of life. Trimmed with Christmas decorations or colored lights they make an attractive novel display and their spicy pleasant odor fills the house. After the holidays, they can be set out as ornamental lawn trees, enjoyed through the summer, and can be dug up and used again the following Christmas, and so on, year after year. An appropriate Christmas gift to a distant friend.

$\$ 1.00$ each, or two for $\$ 1.75$ postpaid. Order now to avoid disappointment, as we can furnish only a limited number each vear. Delivery before Christmas guaranteed.
Every tree in this collection must suit you on arrival, or your money refunded. No investment of so small an amount will add so much to the value of your

urnished complete, labelled, generich loam, well packed for safe shipment, safe

\section{All 9 Exceptional $\$ 24.75$}

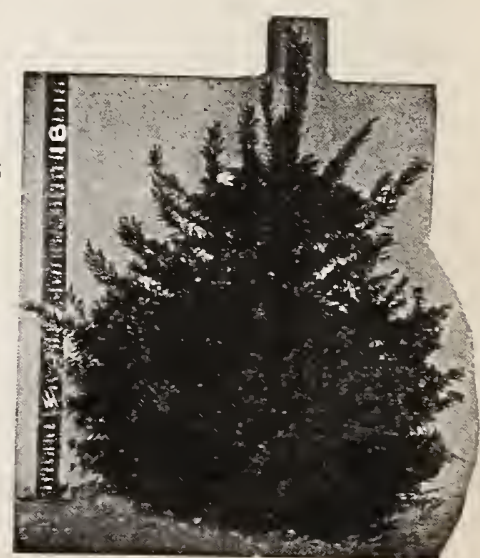




\section{Collins International Evergreens}

They have originated in many different countries. In this group is a $2-2 \mathrm{r} / 2$ foot specimen of the GOLDEN PLUME CYPRESS (a) from Japan. Northern Asia is the source of the sturdy SIBERIAN ARBORVITA (b), of which we furnish a beautiful 1-1 I/2 foot blue-green specimen. The hardy CANADIAN HEMLOCK (c) of woodsy light green foliage, is ideal for the foundation planting, furnished $1 \mathrm{I} / 2-2 \mathrm{ft}$. high. Rigorous Arctic winters are not too severe for the popular rich green NORWAY SPRUCE (d) furnished 1-1 $1 / 2 \mathrm{ft}$. Fittingly from ancient Greece comes the finely sculptured GREEK JUNIPER (e) of striking blue, 1-1 1/2 ft. high. America's own COMPACT ARBORVITA (f) a deepgreen living ball $1-1 / 2 \mathrm{ft}$. high completes the assortment. (Letters above and in diagram refer to photo.)

A half-dozen closely clipped, compact, richly colored specimens. All six prepared when ordered, ready for shipment or delivery, $\$ 14.75$. Kept in form by clipping off the ends once a year (spring).

\section{6 for $\$ 14.75$}

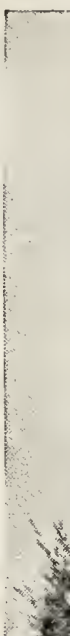

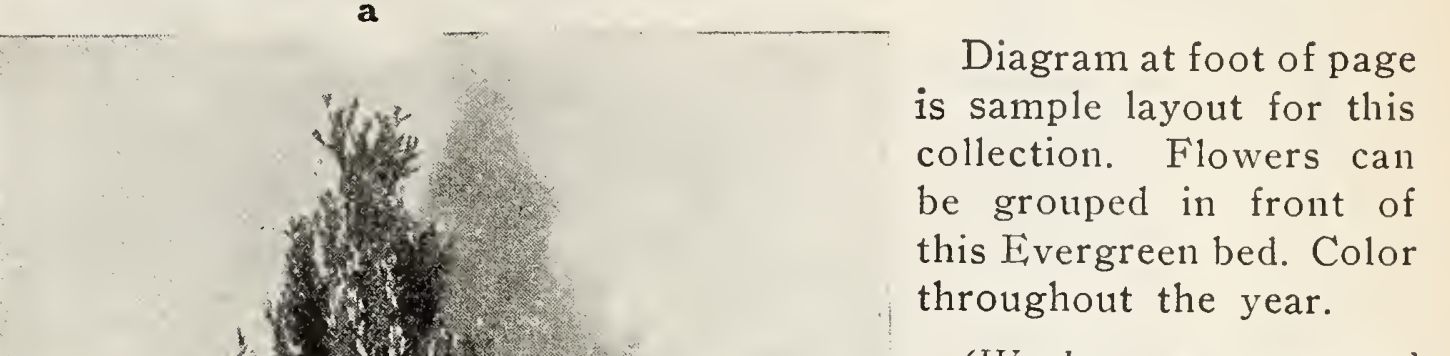

(We have trees reserved in our Nurseries for only a limited number of these collections, and undoubtedly will be unable to offer this group after this season. Order early).

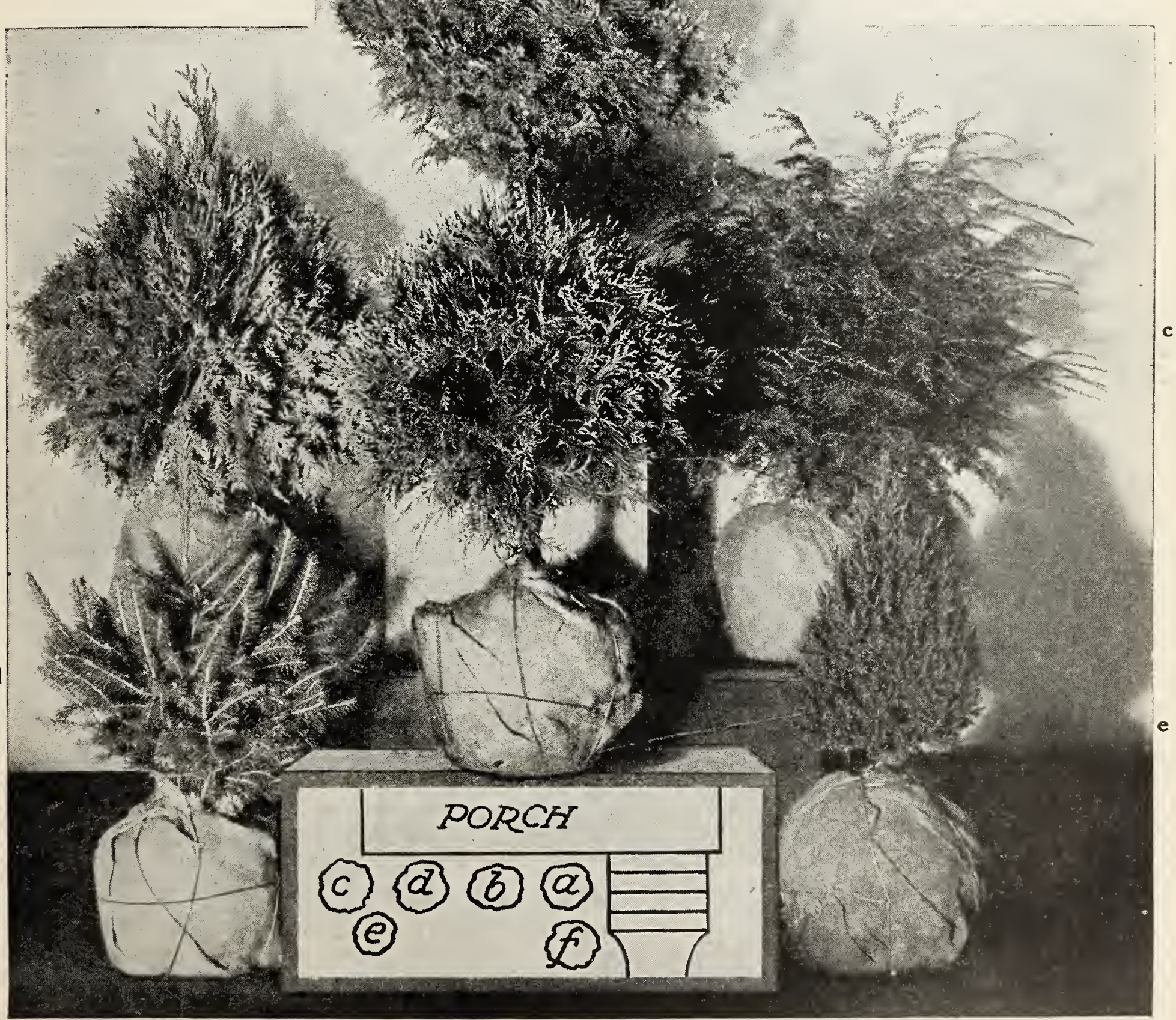




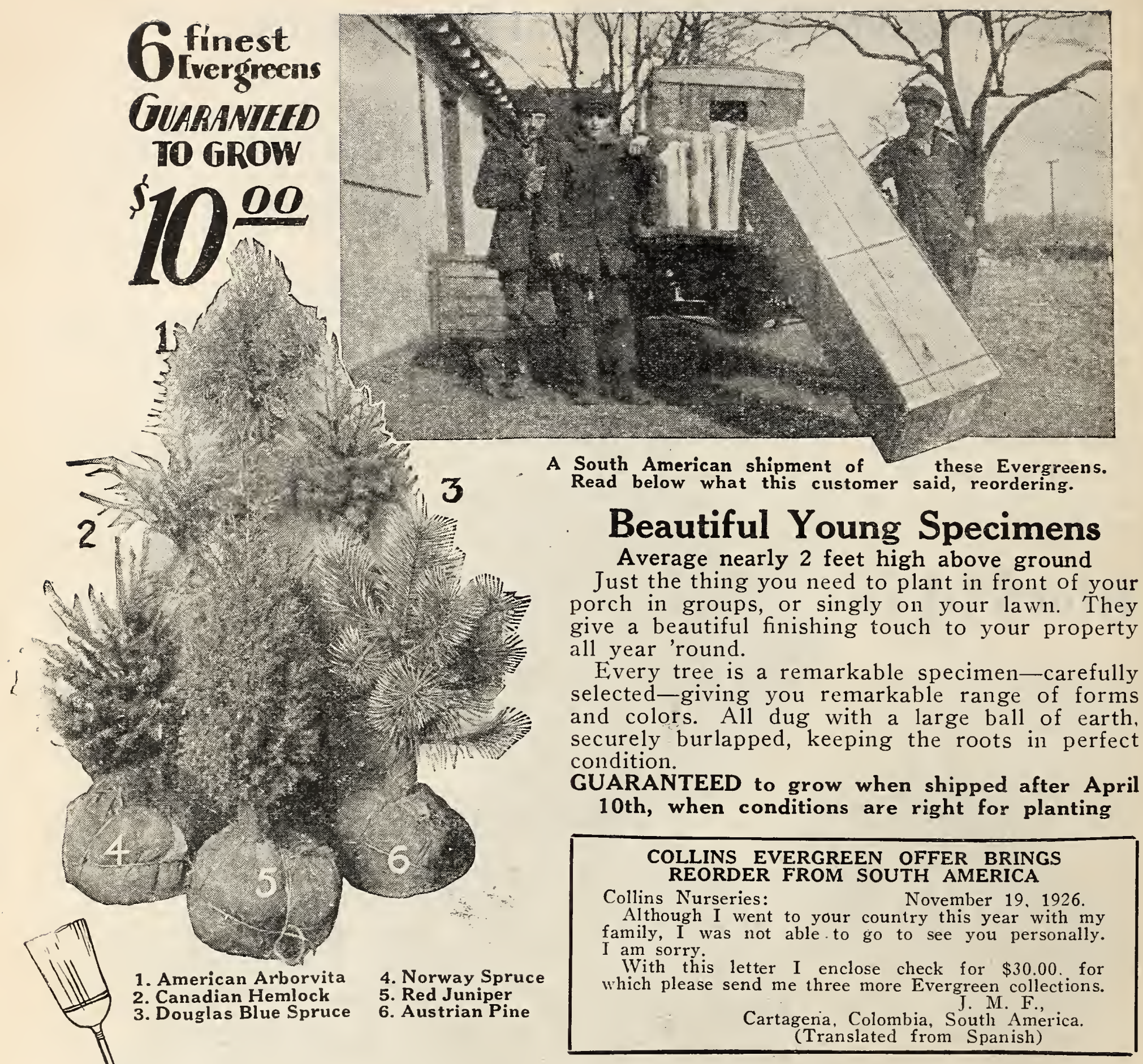

\section{How to Plant and Care for Evergreens}

Dig hole $11 / 2$ times larger and deeper than ball of evergreen. In the bottom put six inches of best top-soil. Without removing the burlap, place tree in the hole so that the level of the surrounding ground is one inch higher than top of ball. Cut strings and fold bag back from top of ball so that it rests in bottom of hole, add good soil on top of this until hole is half full. Then pour in a bucket or two of water, after which fill the hole with your best topsoil. Do not heap earth up about tree, but have ground

Water your evergreens this way for the best results.

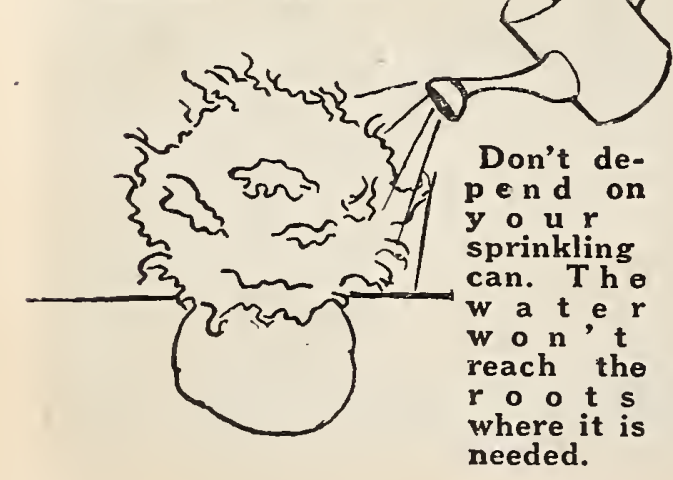
saucer-shaped to catch rainfall. After a few weeks use old manure and cultivate from time to time to keep soil mellow. Crisp, erect, foliage on the evergreens indicates a happy tree; with soft and drooping foliage the tree needs watering.

The most important attention you can give them is the frequent watering at the roots. To water properly, punch holes with a hoe or broom handle in the soft earth around the ball of earth, about 18 inches deep, as shown in the illustration at the left. By pouring water in these holes it gets to the roots where it is needed. Occasionally wash the dust off the foliage. Do not depend on a sprinkling can, since the water does not soak down sufficiently far to be of value to the lower roots. 
A typical letter from one of the many satisfied customers who have re-ordered this collection.

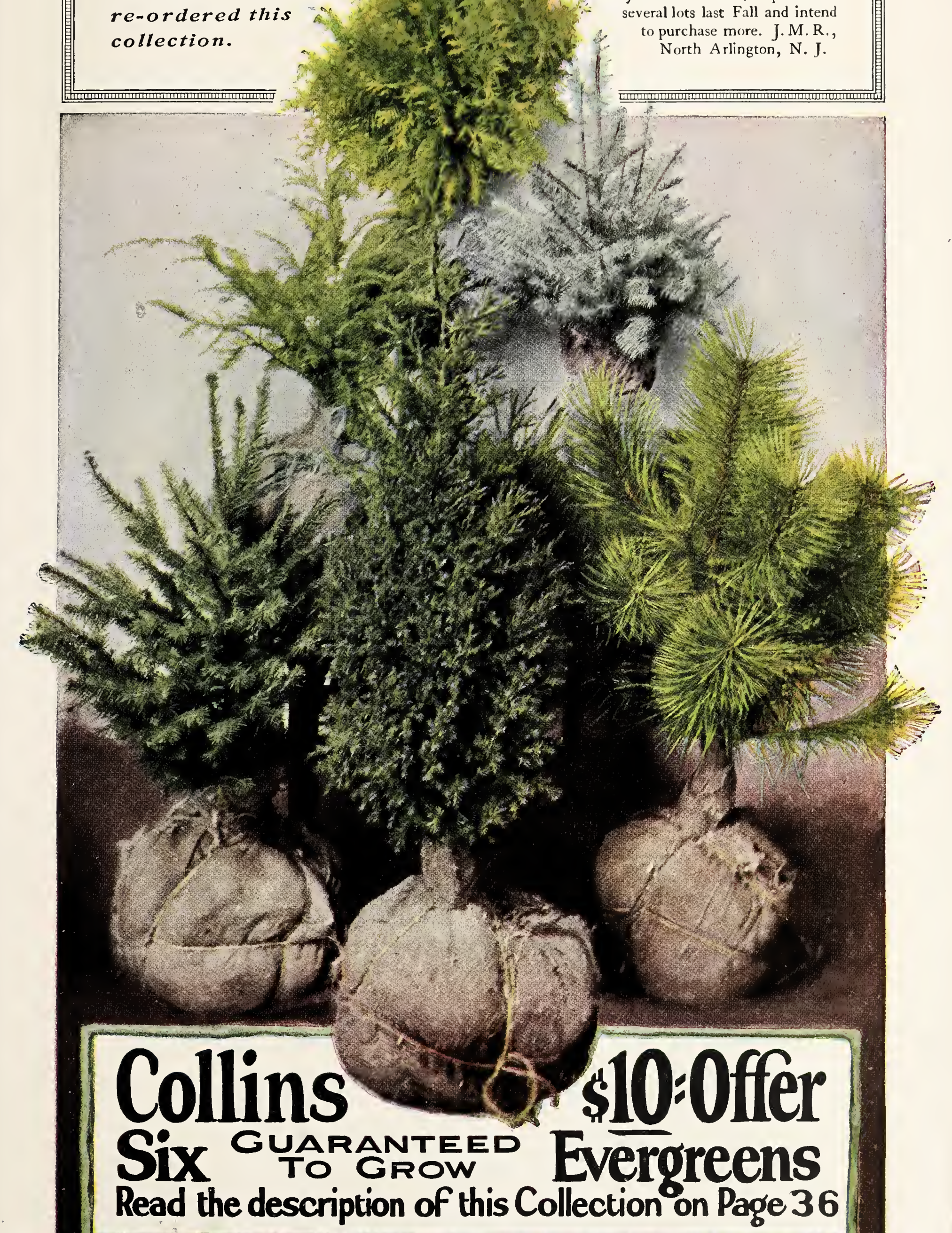



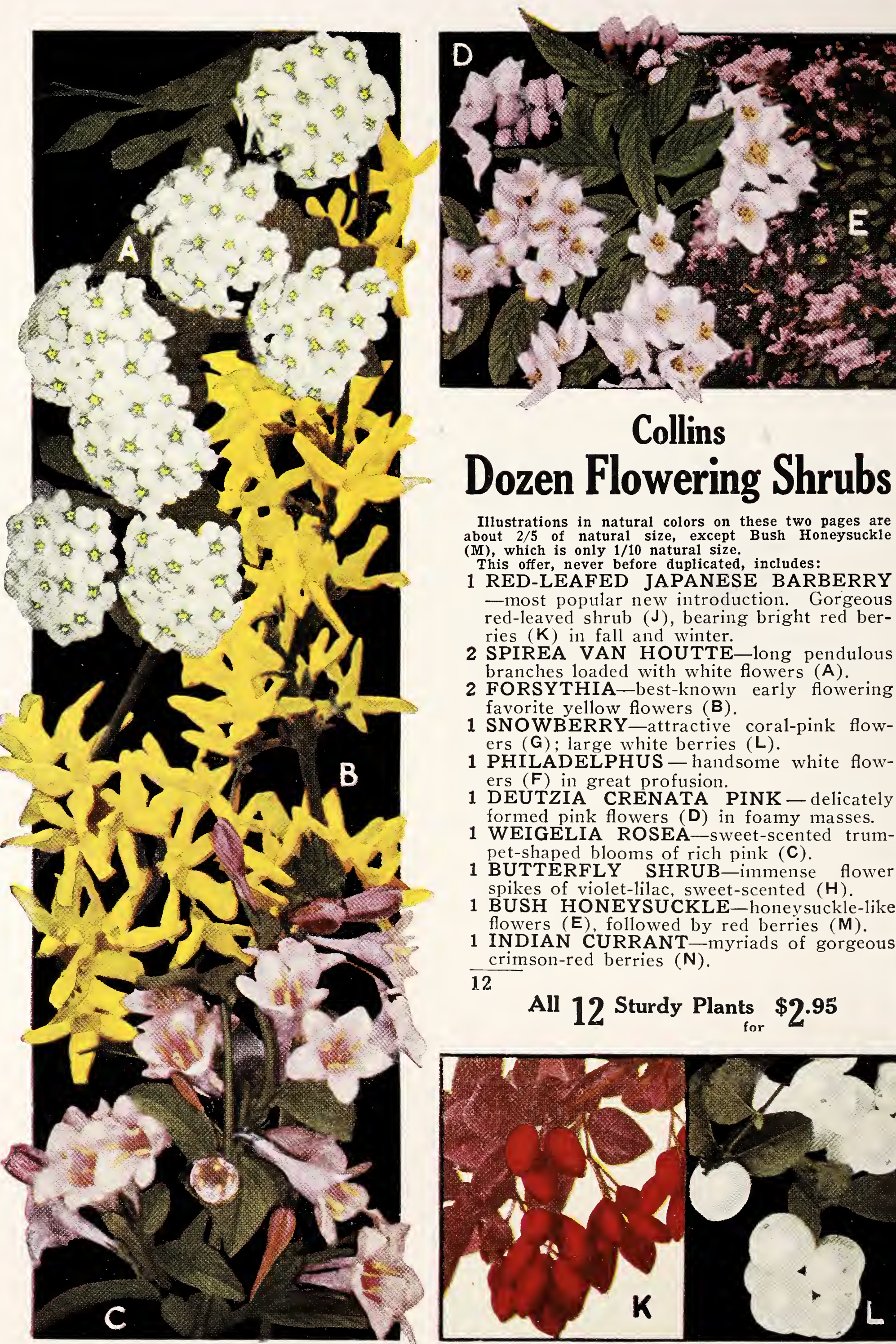

Illustrations in natural colors on these two pages are about $2 / 5$ of natural size, except Bush Honeysuckle (M), which is only $1 / 10$ natural size.

This offer, never before duplicated, includes:

1 RED-LEAFED JAPANESE BARBERRY -most popular new introduction. Gorgeous red-leaved shrub $(J)$, bearing bright red berries $(K)$ in fall and winter.

2 SPIREA VAN HOUTTE-long pendulous branches loaded with white flowers (A).

2 FORSYTHIA-best-known early flowering favorite yellow flowers (B).

1 SNOWBERRY - attractive coral-pink flowers (G) ; large white berries (L).

1 PHILADELPHUS - handsome white flowers (F) in great profusion.

1 DEUTZIA CRENATA PINK - delicately formed pink flowers (D) in foamy masses.

1 WEIGELIA ROSEA-sweet-scented trumpet-shaped blooms of rich pink (C).

1 BUTTERFLY SHRUB-immense flower spikes of violet-lilac, sweet-scented $(H)$.

1 BUSH HONEYSUCKLE-honeysuckle-like flowers (E), followed by red berries (M).

1 INDIAN CURRANT-myriads of gorgeous crimson-red berries $(\mathbf{N})$.

12

All 12 Sturdy Plants $\$ 2.95$

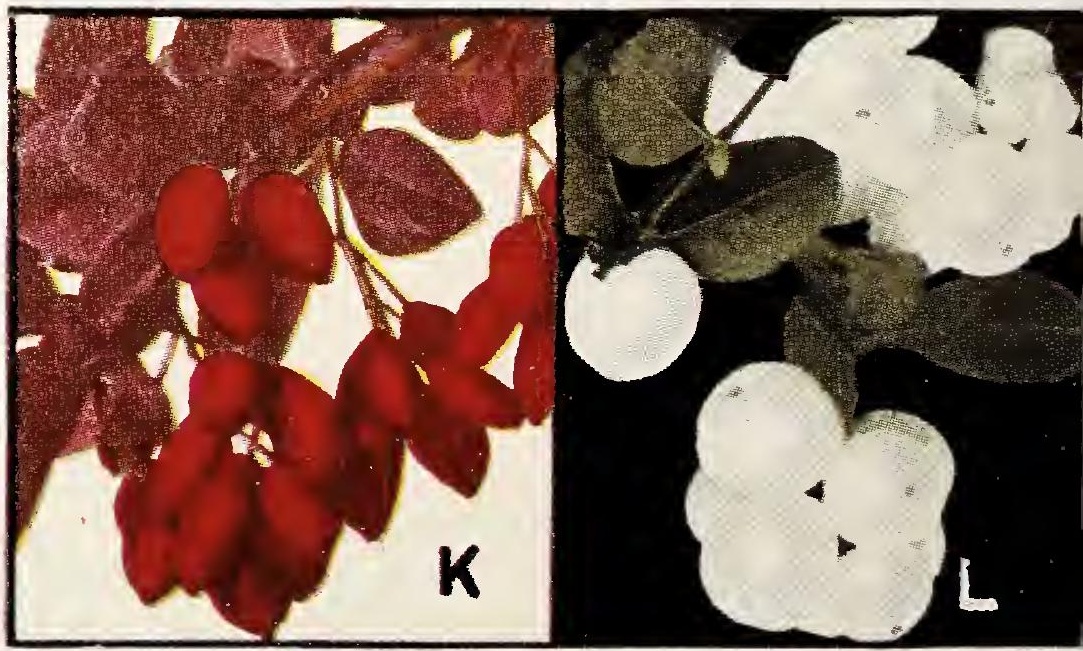




\section{FREE forAutumn orders

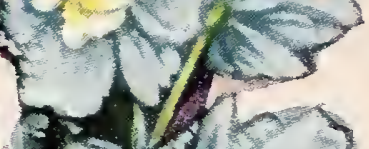 The'DAZZLER" \\ See Page 41}
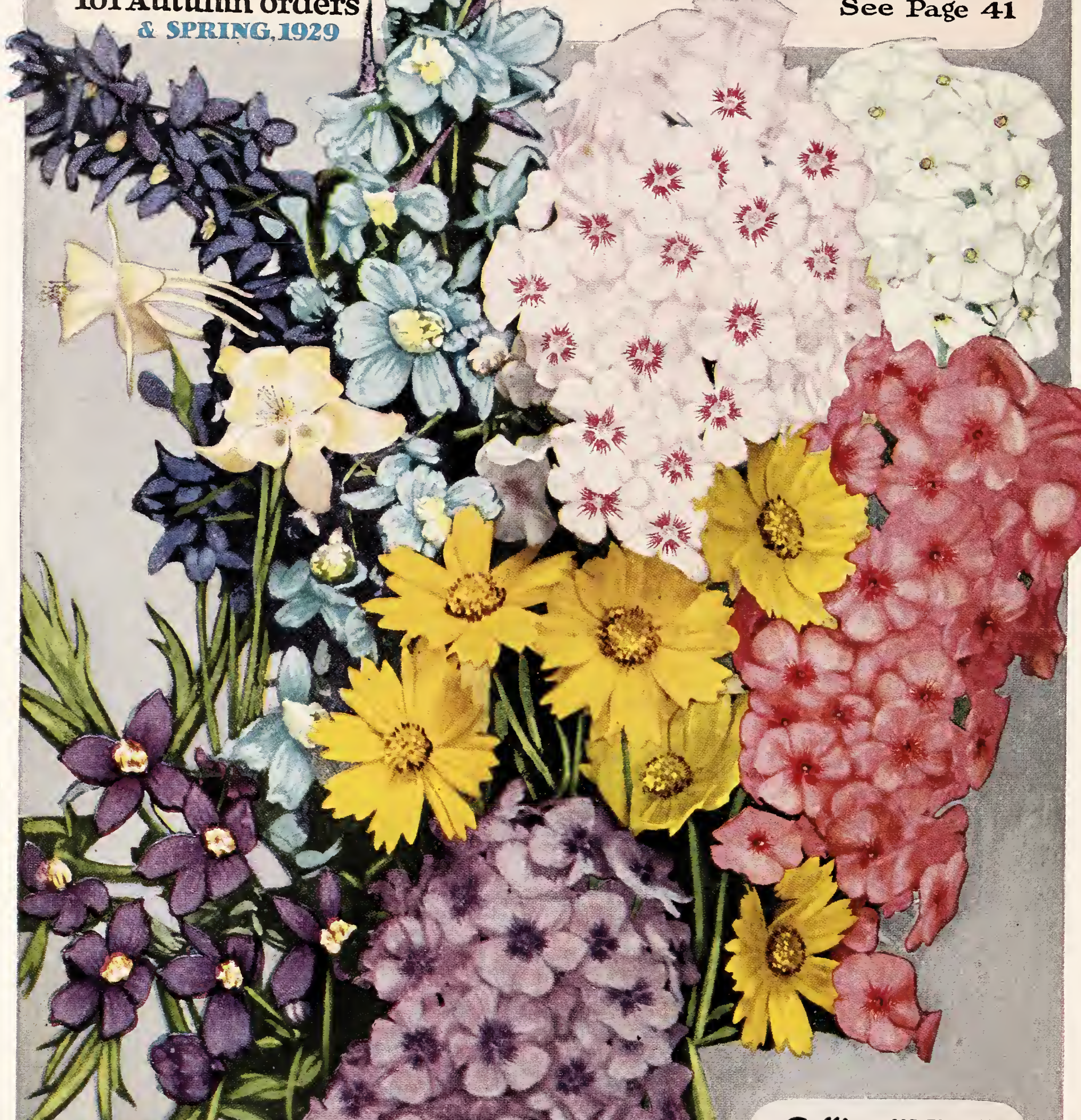


\section{FREE-_"The Dazzler"}

\section{The Marvelous New Gaillardia}

(Blanket Flower)

Are you one of the fortunate few who have seen this most dazzling improvement of years among Perennials and Hardy Flowers since its introduction last season? If so, you'll call meagre and insufficient any attempt at a description of its marvelous large flowers, often more than $31 / 2$ " across which are borne on straight strong stems with their broad petals of "glowing red-maroon, sparkling with golden yellow tips. Ideal for bouquets. Any description gives little idea of its all-summer-long beauties.

To those who have seen its glories, 50 cts. each, or $\$ 5.00$ a dozen for sturdy plants of this "Dazzler" seems phenomenally low.

To be sure they were seen by as many as possible this year, we set aside a limited number of these $50 \mathrm{ct}$. plants anclin our fall catalog-offered one of them

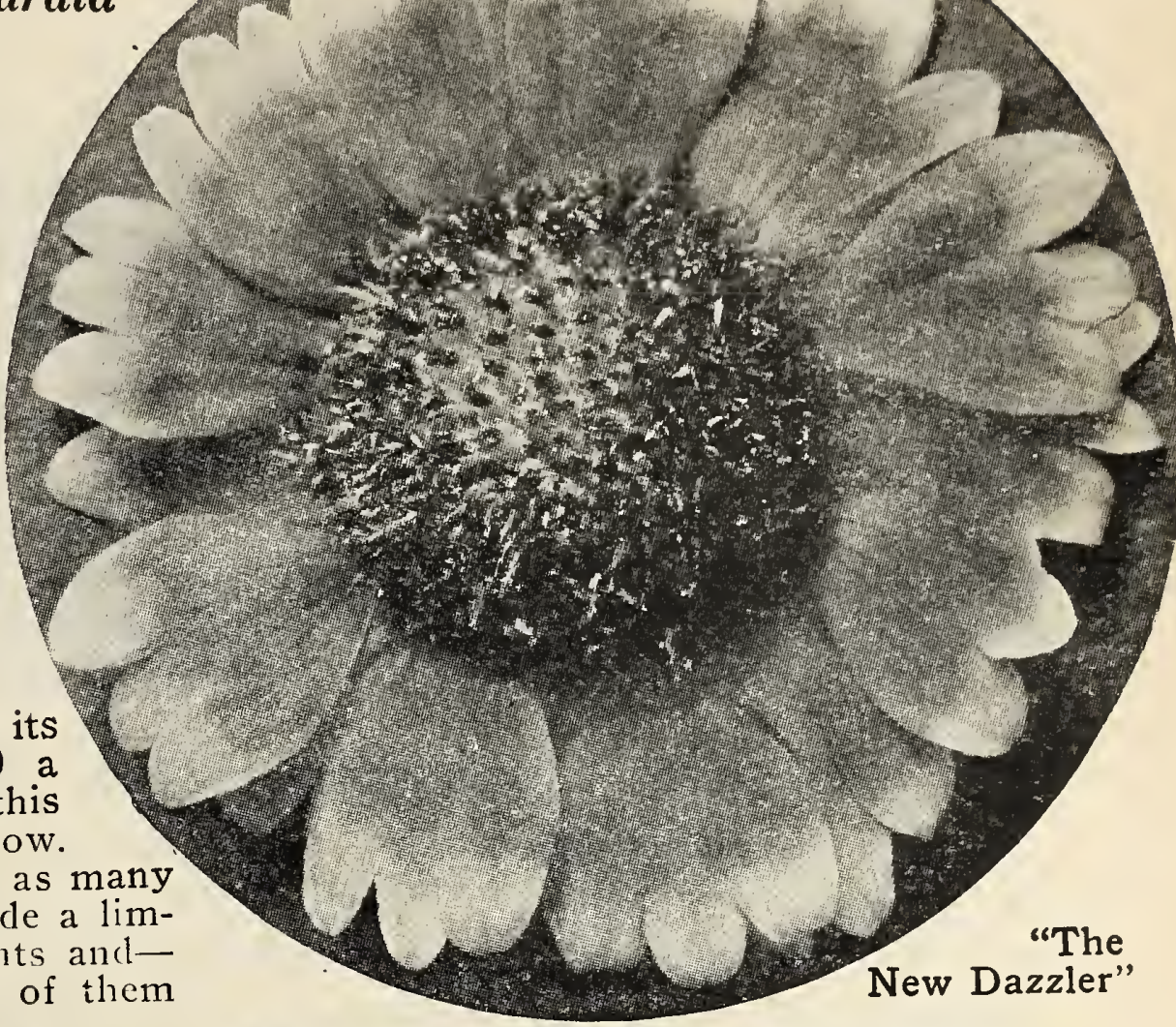

\section{FREE Collins Color Plate Perennial Offer}

\section{with each $(S h o w n 2 / 5$ natural size on color plate opposite)}

This offer was restricted to last autumn because we wanted to bring into that season a large part of the tremendous sale of these Perennial offers, to the advantage of both our customers and ourselves. But so many asked that we ship this spring-that we feel impelled in fairness to all to set aside an additional supply of these remarkable plants for such shipment. The first 1000 orders for this Perennial Color Plate Offer will therefore include

\section{One "Dazzler" Gaillardia \\ F R E E, in addition to \\ ALL 9 Hardy Plants \\ (See Color Photo) \\ $\$ 1.95$ Postpaid}

Even without the inclusion of the "Dazzler" this has been acclaimed by many customers the most remarkable Perennial value they ever secured. Remarkable for its sturdy growing plants, bearing a profusion of bright, alluring flowers-varied in form, color and fragrance-from early spring to late fall frosts. Big sturdy plants producing large bouquets of cut flowers surprisingly soon and an ever-increasing quantity of bloom each year.

\section{Plants DELPHINIUM (HARDY LARKSPUR)}

One each of the three finest, most popular varieties-

BELLADONNA-Large sprays of sky blue flowers, white centers.

GELLADONNA-Large sprays -Gentian-blue. Finely divided foliage. $2 \mathrm{ft}$. June to Sept. BELLAMOSUM-Intensely rich deep royal blue flowers.

These choicest delphiniums introduce into your garden the rarest and richest of blue colors. Erect, stately spikes up to $6 \mathrm{ft}$. high, in all conceivable shades of blue, set among beautifully cut foliage aplenty. June till September. Last for days as cut flowers.

\section{Plants HARDY PHLOX}

The old favorite in never more beautiful shades of salmon-pink, cerise and scarlet, lilac-blue and violet, soft pearl pink with rose eyes, and cream white and white with almost hidden eyes. How gorgeously they take up the pace of June blaze of color and keep the garden vividly beautiful through the hottest summer months, and through the fall until the anemones and veronicas begin to bloom. Great fluwer clusters. An incessant succession of brilliantly colored blooms. Pervaded with a delicate fragrance.

\section{Plant COREOPSIS-Special Large Flower Strain}

Golden-yellow blooms, often three inches across, early June till after Thanksgivingnever out of bloom. A large clump soon develops, bearing hundreds of blooms. Perfect for cutting. last long. brighten any bouquet.

1 Plant AQUILEGIA (COLUMBINE), Mrs. Elliott's Long Spurred Strain

From May on, these highly developed very long spurred Columbines reward you with quantities of gay, airy blooms of distinctive shape, very large, ideal for cutting. Delightful color combinations of lavender, cream, pink, blue, white and red. 


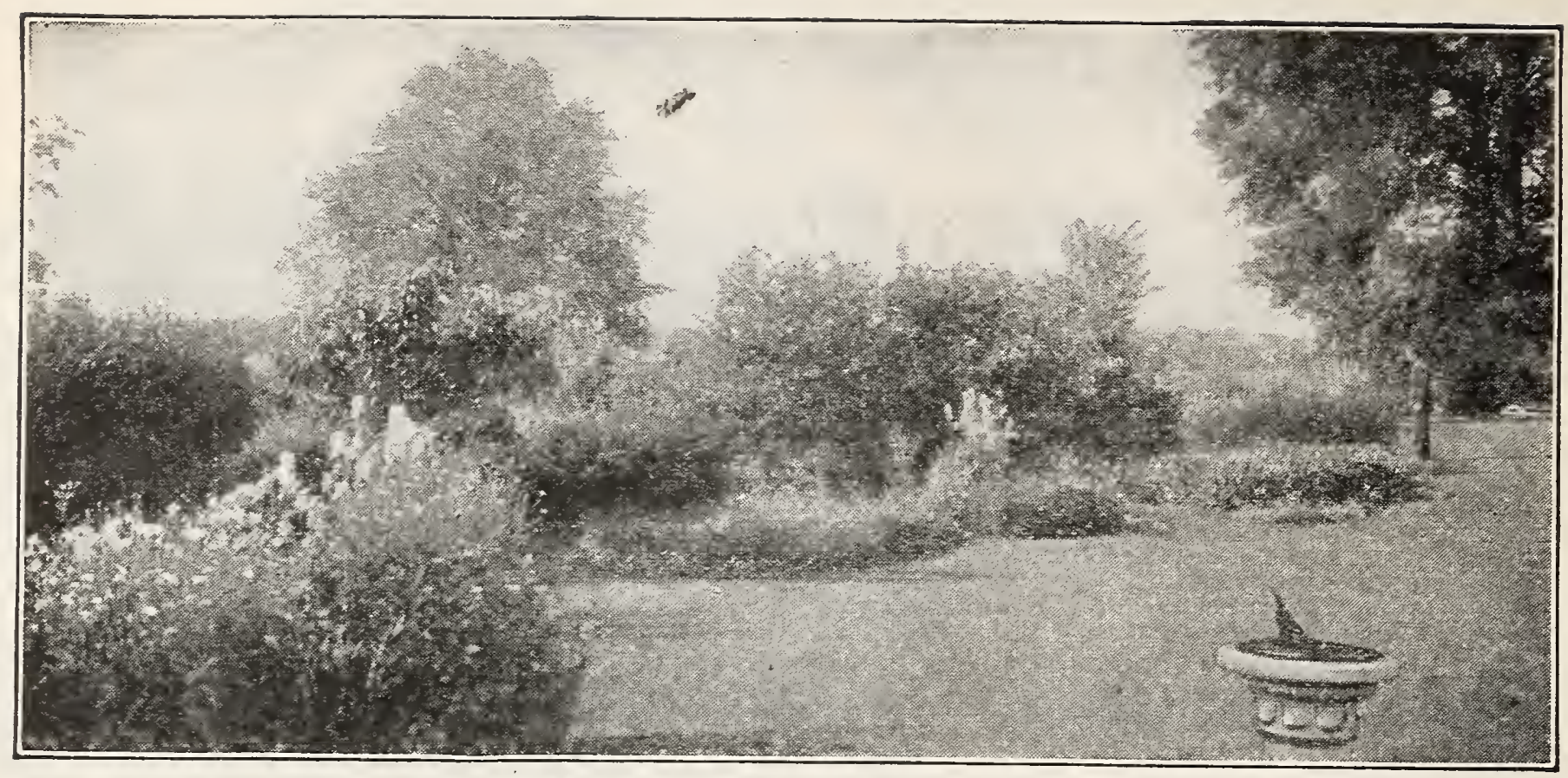

\section{Collins Hardy Perennials (Old Fashioned Flowers)}

Armloads of beautiful blooms, of every conceivable shape and color from this perennial garden, was the feature of the first blooming season. Increased wealth of bloom each succeeding year, for hardy perennials increase amazingly. What wondrous flowers for cutting, what delights every month from the improved varieties as follows.

Prices of all Perennials include postage and safe delivery to you. Since groups of 3 are the general preference, individual prices are not quoted. Plants at $\$ 2.00$ or $\$ 2.50$ per doz. are $25 \mathrm{c}$ each; $\$ 3.00$ per doz., 30c each; $\$ 3.50$ per doz., $35 \mathrm{c}$ each; $\$ 4.00$ per doz., $40 \mathrm{c}$ each.

\section{ACHILLEA (Milfoil or Yarrow)}

PTARMICA, THE PEARL. Indispensable in the border. Myriads of snow-white ballshaped flowers, borne in great profusion all summer. Excellent for cutting, makes it bloom more than ever. $2 \mathrm{ft}$. May to Oct. 3 plants $65 \mathrm{c} ; \$ 2.50$ per dozen.

MILLEFOLIUM ROSEUM (Rosy Milfoil). Dense heads of bright pink flowers, quantities of bloom throughout summer. 18 inches. 3 plants $65 \mathrm{c} ; \$ 2.50$ per dozen.

\section{ANCHUSA ITALICA (Improved Italian Alkanet)}

DROPMORE VARIETY. Bright gentian-blue flowers in immense upright spikes comparable to Larkspurs or giant Forget-Me-Nots. 3 to $6 \mathrm{ft}$. May to Aug. 3 plants $65 \mathrm{c} ; \$ 2.50$ per dozen.

\section{ANEMONE JAPONICA (Japanese Windflower)}

QUEEN CHARLOTTE. Beautiful pale silvery pink flowers, a rare color among Perennials, semi-double, two or three inches in diameter. Very decorative foliage. Strikingly handsome plant in the border, among shrubbery, or in clumps under trees. Excellent for cutting. 2 to $3 \mathrm{ft}$. Sept. and Oct. 3 plants $80 \mathrm{c} ; \$ 3.00$ per dozen.

\section{AQUILEGIA (Columbine)}

Elegant forms and shadings, lavish blooms, brightening the border. Taluable for cutting.

CHRYSANTHA. Tall, very beautiful. Bright yellow flowers with long spurs. $3 \mathrm{ft}$. May and June.
3 plants $65 \mathrm{c} ; \$ 2.50$ per dozen.

MRS. SCOTT ELLIOTT'S. STRAIN. The best long-spurred, thrifty hybrids. Large blooms of rich and varied colors (pink, lavender, yellow, etc.), practically every one different. 2 to $3 \mathrm{ft}$. May and June. 3 plants $80 \mathrm{c} ; \$ 3.00$ per dozen.

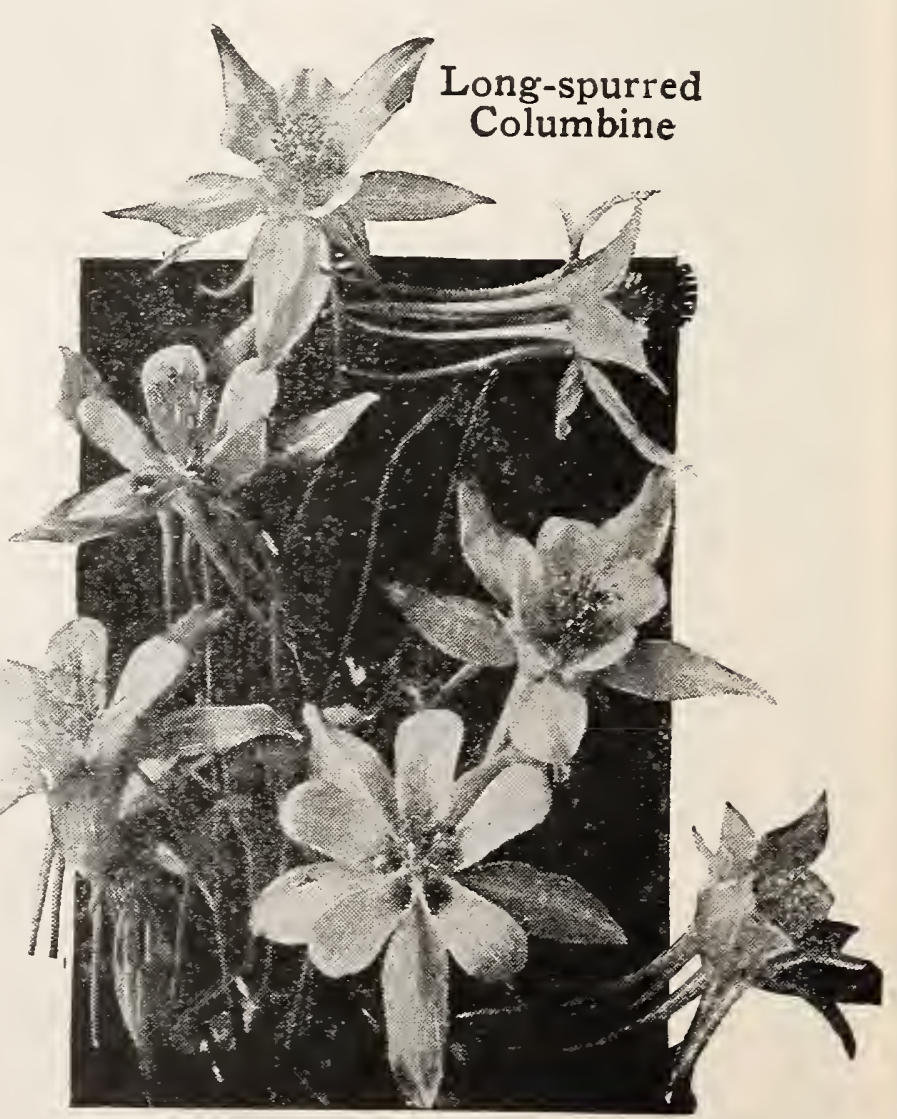




\section{HARDY ASTERS (Michaelmas Daisies)}

Excellent for borders and shrubbery. Wealth of bloom, September and October. PERRY'S WHITE. Free-flowering. Large, graceful flowers, fine for cutting. $4 \mathrm{ft}$. CLIMAX. Large pale mauve flowers with yellow centers, on long, slender stems. $3 \mathrm{ft}$.

All Hardy Asters 3 plants 65 cts.; per doz. $\$ 2.50$

\section{CAMPANULA (Bellflower)}

One of the most beautiful of hardy plants, indispensable to the Perennial border.

CARPATICA. Large purple-blue flowers, cup-shaped, on delicate stems. Compact plants, valuable for edging and rock gardens. 8 inches. June to October

CARPATICA ALBA. A white variety of the preceding. 8 inches. June to October.

CAMPANULA MEDIUM (Canterbury Bells). Fine for borders or cutting. Bellshaped flowers 1 to $2 \mathrm{in}$. long, erect stems. $3 \mathrm{ft}$. Blue, pink, and white. June to August.

All Campanulas 3 plants 65 cts.; per doz. $\$ 2.50$

\section{CHRYSANTHEMUMS (See Color Plate Offer on page 1)}

POMPON OR BUTTON CHRYSANTHEMUMS. Charming little flowers about an inch in diameter, borne in profusion. Each 25 cts.

Golden Crest. Rich golden yellow. Iva. Deep bronze. Neo. Soft shell-pink. Little Dot. Crimson mahogany. Model of Perfection. Pure white.

SPECIAL OFFER: one of each of 5 above for $\$ 1.00$ postpaid.

THE NEW CHRYSANTHEMUM-MRS. CALVIN COOLIDGE. Magnificent new "Mum" of a startling cardinal-red. Very large. Single. Plant grows well and flowers are produced in great quantities. 50 cts. each; $\$ 5$ per dozen.

\section{CHRYSANTHEMUM MAX (Shasta Daisy)}

MAXIMUM. A great favorite for cutting. Profusion of large, white daisy-like flowers, over 4 in. across, borne June to September. $2 \mathrm{ft}$. 3 plants $65 \mathrm{cts}$; per doz. $\$ 2.50$.

\section{COREOPSIS (Tickseed)}

GRANDIFLORA. Large bright orange-yellow flowers, borne on graceful stems. Excellent in masses, giving a brilliant note of yellow through the greater part of the summer. Fine for cutting, blooms incessantly. $2 \mathrm{ft}$. June to October. 3 plants $55 \mathrm{cts}$; per doz. $\$ 2.00$.

\section{DELPHINIUM (Hardy Larkspur)}

Doubtless the Hardy Larkspurs are the most beautiful of Hardy Garden Flowers with their sparkling shades of blue and tall, stately forms. Soil should be deeply dug and enriched with rotted manure, plants should be mulched from hot sun, and watered in hot weather. After blooming the plant should be cut to the ground, given a dressing of bonemeal, and well watered.

BELLADONNA. Vivid sky-blue flowers of great delicacy and beauty, $11 / 2$ inches across with white centers, borne in graceful spikes 12 inches long, in great profusion from June to frost. Excellent for cutting. 3 plants 65 cts.; per doz. $\$ 2.50$.

BELLAMOSUM. A wonderful deep royal blue, making an excellent contrast to the other varieties. 3 plants for 65 cts.; per doz. $\$ 2.50$.

GRANDIFLORUM. Intense gentian-blue flowers freely produced with feathery foliage. Much desired. 3 plants for 65 cts; per doz. $\$ 2.50$.

COLLINS MIXED HYBRIDS. The original stock is raised from seed of the $H$. J. Jones collection of named varieties, forming an excellent assortment. The colors vary through all shades from lightest blue to dark purple, with blue, black, white, or gray centers. Huge flower spikes, 2 feet long or more, on stems 4 to 8 feet high. June, July, September and October. 3 plants 80 cts.; per doz. $\$ 3.00$.

\section{LINUM (Flax)}

PERENNE. All summer long this very satisfactory rockery and border plant presents a succession of sapphire-blue flowers. $2 \mathrm{ft}$. 3 plants 65 cts.; per doz. $\$ 2.50$.

Prices of all Perennials include postage and safe delivery

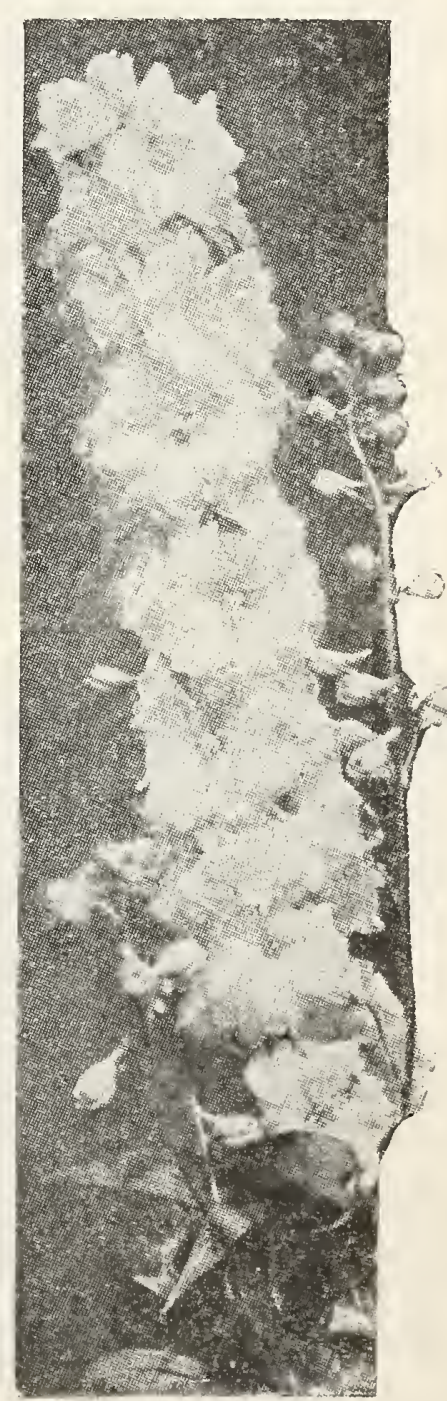

Delphinium 


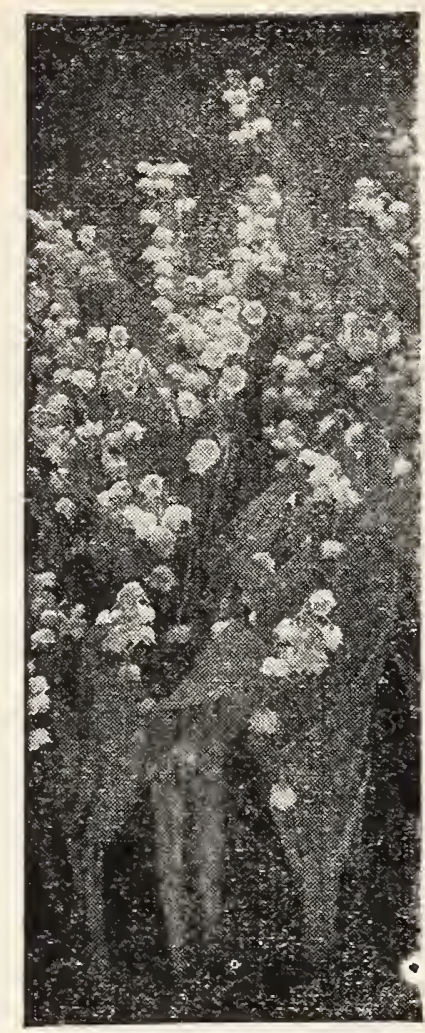

Lily-of-the-Valley

\section{CONVALLARIA (Lily-of-the-Valley)}

MAJALIS. These small bell-like flowers, so very fragrant, have endeared themselves to garden lovers for many years. Requiring little or no attention, they maintain a fine foliage even when not in bloom. Excellent for ground covering and thrives in shade. Groups (of 6 to 8 pips), 50 cts. each; $\$ 4.50$ per 10 groups.

\section{DIANTHUS (Pinks)}

ALLWOODI. (New Perpetual Hardy Pinks.) This is a valuable addition to Hardy Perennials. In perpetual bloom from early spring until late fall, with somewhat larger flowers of better substance, highly clove-scented. Fine stems for cutting. Collins Perpetual Pinks assorted (see illustration below): Fine range of colors. 3 plants for 65 cts.; per doz., $\$ 2.50$.

PLUMARIUS (Hardy Pinks). Best old-garden favorites. Excellent for edging the hardy border. Neat, attractive, foliage, even in winter. Also fine for rock gardens and for cutting. Profusion of clove-scented blooms in May and June; carnation-like, 6 to 12 inches high. 3 plants for 65 cts.; per doz. $\$ 2.50$.

MISS GLADYS CRANFIELD. A fine new variety; awarded certificate of merit by the R. H. S. of England. Beautiful fringed flowers of most attractive rose-pink with deep velvety-maroon centers. Foot high stems. Vigorous. Desirable for border. Fine for cut-flowers. We offer the true stock. 3 plants 80 cts.; per doz. $\$ 3.00$.

\section{DIANTHUS BARBATUS (Sweet William)}

Bright spots of color in the border. Fine for cutting. Dense clusters often $4 \mathrm{in}$. across of 20 to 30 flowers from May to July. Prices of the following, 3 plants for 65 cts.; per doz. $\$ 2.50$.

NEWPORT PINK. Captivating salmon-pink. 18 inches.

HOLBORN GLORY. Various colors. 18 inches.

\section{DIGITALIS (Fox Glove)}

GIANT SHIRLEY HYBRIDS. A fine new strain raised by the late Rev. W. Wills. Enormous blooms borne on flower spikes towering to 7 feet. Colors, from pure white to deepest rose with interesting chocolate spots. 3 plants for 65 cts.; per doz. $\$ 2.50$.

\section{Appropriate Edging Plants}

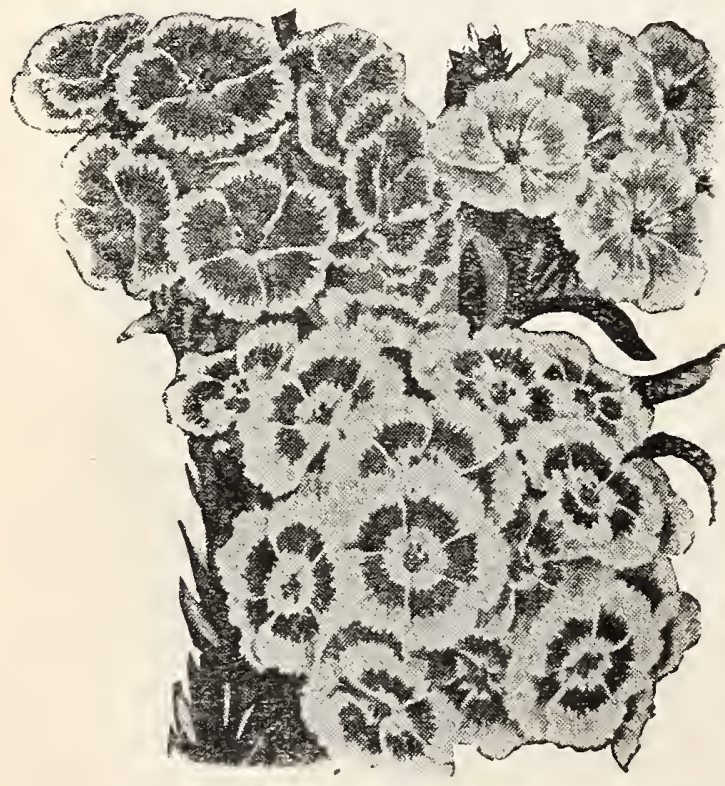

Sweet William-dense clusters, fine for cutting
Dainty plants, interesting foliage, that soon make a living flowering "fence" (less than 12 inches high) to your flower beds. Glowing, fascinating, gay flowers.

ALYSSUM SAXATILE COIMPACTUM. (Gold Dust.) Dwarf golden tufts in masses April and May. 12 in. NEPETA MUSSINA (Catmint). Many stemmed, trailing plant, silvery leaves, bears spikes of lavender blue flowers in great profusion in June. Effective in large masses. $1 \mathrm{ft}$.

IBERIS SEMPERVIRENS. (Evergreen Candytuft.) Invaluable for edging. Dwarf, compact evergreen foliage. Large trusses of white flowers April-May. 9 in.

DIANTHUS DELTOIDES. (Maiden Pink.) Beautiful border plant, gracefully trailing, covered with charming pink flowers. June and July. 8 in.

VIOLA CORNUTA. (Viola Jersey Gem.) One of the best, blooming freely spring, summer and fall. Royal purple flowers. Foliage, rich green. 6 in.

ARABIS ALPINA. (Alpine Rock Cress.) Very valuable border plant, blooming early in April and May with quantities of beautiful white flowers. 6 in.

Each 30 cts.; or 18 (3 of each variety), $\$ 3.85$ postpaid. Prices of all Perennials include postage and safe delivery 


\section{DIANTHUS CARYOPHYLLUS (Hardy Carnation)}

A very special strain of exceedingly hardy outdoor Carnations. Flowers large and very double. Almost rival greenhouse carnations in size and beauty. Very sweet-scented and fill a great need in this class of plants. Double flowering: Blush Pink, Pure white, Dazzling Scarlet, Splendid Lilac, Dark Red, Pure Yellow, Dark Purple. 35 cts. each; $\$ 3.25$ per doz. Hardy German strain, mixed, 7 for $\$ 1.95$, postpaid.

\section{DIELYTRA (Bleeding Heart)}

SPECTABILIS. Fascinating heart-shaped flowers, rosy-red with white petals, hanging delicately along graceful arching stems amid dainty fern-like foliage. A great favorite in old-fashioned gardens, for shady places. 18 inches. Early April through June. $50 \mathrm{cts}$. each; $\$ 5.00$ per doz.

\section{GAILLARDIA (Blanket Flower)}

GRANDIFLORA. Brilliant coloring and profuse flowering over a long season. Exceedingly valuable in the border. Shades from brilliant yellow at the tips of the flower to red toward the center. Stems 3 feet high from June to after frost, a neverending array. Excellent for cutting. 3 plants for 65 cts.; $\$ 2.50$ per doz.

THE "DAZZLER." Iatest development in Gaillardias. Described on page 41.

\section{GYPSOPHILA (Baby's Breath)}

PANICULATA. Myriads of tiny white flowers borne all over the many branches. Prized for bouquets and garnishing. $2 \frac{1}{2} \mathrm{ft}$. July and August. 3 plants for 65 cts.; per doz. $\$ 2.50$.

DOUBLE FLOWERING "BRISTOL FAIRY." New. The value of Baby's Breath for nearly every bouquet is well-known. This new Bristol Fairy is a great advance in the improvement of the double forms, the flowers are larger and whiter, the plant much stronger in growth and even more graceful. It flowers practically throughout the season, June to November. Grafted plants $85 \mathrm{cts}$. each; per doz. $\$ 8.50$

\section{HIBISCUS (Mallow)}

NEW GIANT FLOWERING MALLOW MARVELS. Striking and effective planted in groups, or naturalized by the water side. Large open flowers, nearly 12 inches across. Borne in quick succession from August to October. Pink, red, white with deep crimson eye. Heavy roots, to bloom this year, 3 plants for 65 cts; per doz. $\$ 2.50$.

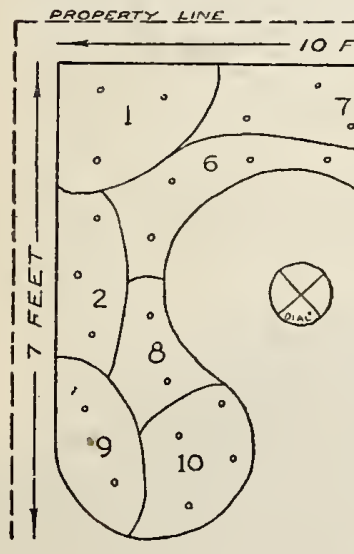

The "FRIENDLY CORNER C L US TER," an all-season-through bed of $\mathrm{Hardy}$ Flowers. plenty of variety of color, plenty of fine blooms for cutting and fine color combinations.
Collins "NEIGHBORLY BORDER" between yours and the next property! Never-ending array of color in flowers.

Key Quan. Variety

13 Campanula

Carpatica

23 Digitalis Giant

33 Chrysanthemum

4. 3 Physalis fran-

4. 3 Physalis

53 Delphinium

belladonna

62 Gaillardia

74 Dianthus Bar.

74 Dianthus Bar.

83 Stokesia Cyanea

24 plants

for $\$ 4.90$

$$
\text { Postpaid }
$$

We recommend edging this bed with 30 old-fashioned Boxwood, 3-5-in., 2 yr., for $\$ 5$.

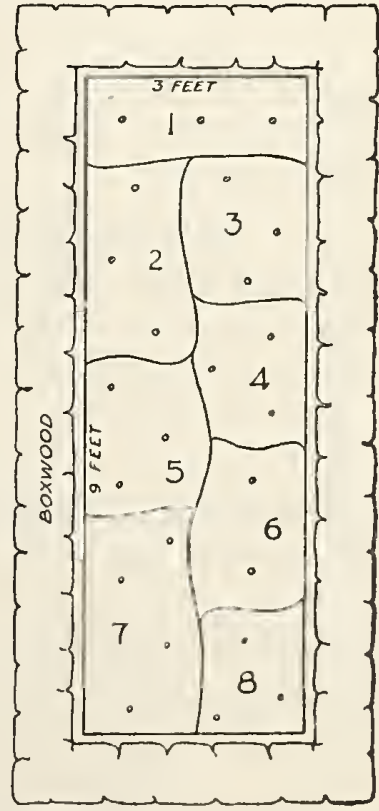

Above Perennials and Boxwood edging, in one shipment- $\$ 9.25$ postpaid. 


\section{COLLINS NURSERIES, MOORESTOWN, N.J.}

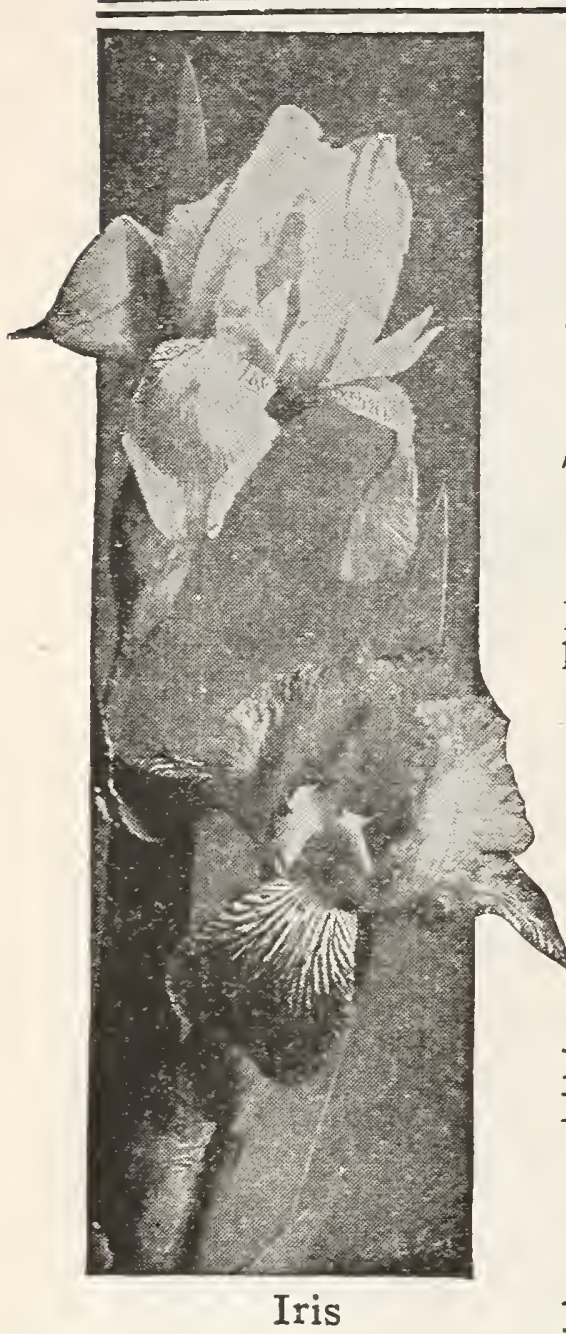

HOLLYHOCKS

Fine old garden favorites, unequaled for planting in rows against walls. Flowers 5 inches across, held high on spire-like stems. July and August. Cultivate deep, enrich well, add plenty of water. Offered separately by colors. Our strain is Chaters celebrated strain.

SINGLE: Assorted. $30 \mathrm{cts}$. each; $\$ 2.75$ per doz.

DOUBLE: Apple Blossom, Bright Rose, Cerise, Crimson, Newport Pink, Salmon, White and Yellow.

SPECIAL OFFER: 1 each of 8 above double colors for $\$ 1.95$.

\section{IRIS GERMANICA (German or Flag Iris)}

Remarkably decorative plants, fine for masses, or in border. Excellent for cutting. Good in sun or shade. Handsome swordlike foliage, large showy blooms. 2 to 3 feet tall. May and June.

LOHENGRIN. Enormous. Standards and falls both soft pink.

LORELY. Standards of light yellow, falls of rich ultramarineblue, with veined border of cream.

PRINCESS VICTORIA LOUISE. Sulphur-yellow standards, falls of rich plum with cream margin.

RHEIN NIXE. White standards, white margined falls of deep blue-violet.

AUREA. A rich chrome yellow. Large perfect flower. HER MAJESTY. Standards rose-pink, bright crimson falls.

PALLIDA DALMATICA. Standards of lavender-blue, falls deep lavender. Large, fragrant. $3 \mathrm{ft} .50 \mathrm{cts}$. each; $\$ 4.50$ per doz. Prices, except where noted, 30 cts. each; $\$ 3.00$ per doz.

SPECIAL OFFER: One each of the above choice varieties (making 7 in the set), postpaid for $\$ 1.95$

MIXED COLORS. Exceptional varieties, $\$ 20.00$ per 100 .

\section{IRIS KAEMPFERI (Japanese Iris)}

Immediately following the German Iris in flowering period. Fine in the border; in front of shrubs, or by water. Excellent for cutting. Huge flowers, ranging from white and blue to deep purple. 2 to $3 \mathrm{ft}$. June and July.

All Colors. Contains a fine assortment of varieties embracing all colors. 3 plants for 65 cts.; per doz. $\$ 2.50$.

\section{LOBELIA (Cardinal Flower)}

CARDINALIS. Intense glowing cardinal-red flower spikes 2 to $2 \mathrm{r} / 2$ feet long. Grow in sun or shade (preferring rich soil). Unrivaled fiery brilliance. 2 to $4 \mathrm{ft}^{\text {. July to }}$ September. 3 plants for 65 cts.; per doz. $\$ 2.50$.

\section{LUPINUS (Lupines)}

POLYPHYLLUS. Very effective. Large stately spikes of pea-shaped, clear blue. Handsome foliage. Fine for cutting. $3 \mathrm{ft}$. May and June. 3 plants 85 cts.; per doz., $\$ 3.50$.

\section{MYOSOTIS (Forget-me-not)}

PALUSTRIS SEMPERFLORENS. Little bright blue flowers with yellow eye and delicate pink buds. Excellent in shady places. 6 to 10 inches. May to October. 3 plants for 65 cts.; per doz., $\$ 2.50$.

PAPAVER ORIENTALE (Oriental Poppy) Gorgeous beauties, rich in striking color. Flowers 6 to 8 in. across, 3 to $31 / 2$ feet high. May and June.

GOLIATH. Most fiery brilliant scarlet. Enormous. ORANGE QUEEN. Very large glowing orange-red. MRS. PERRY. Charming salmon-rose. Fine large flower.

3 plants of one variety, 80 cts, ; per doz., $\$ 3.00$.

ASSORTED COLORS. Unusual shades. 3 plants 65 cts.; per doz., $\$ 2.50$.

Prices of all Perennials include postage and safe delivery,

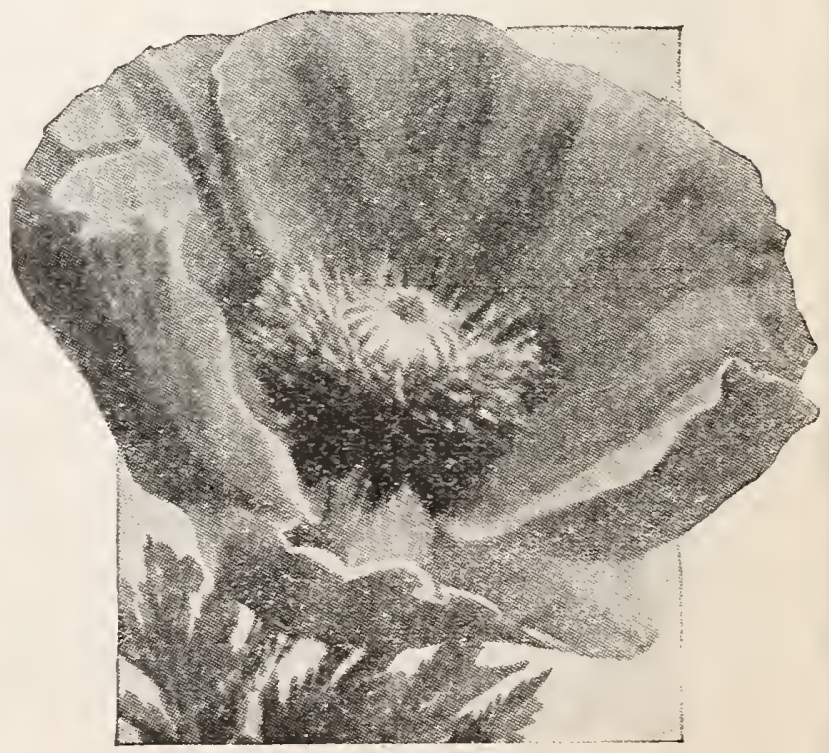

Oriental Poppy 


\section{Collins Chosen}

\section{Peonies}

A careful selection of the right varieties.

Plant in good, rich earth, standing them up, covering with from two to three inches of earth, $31 / 2$ to 4 feet apart.

The stately beauty and wealth of color of Peony blooms make them especially va $1 \mathrm{u}$ a b $1 \mathrm{e}$ throughout the perennial bed; or alone. Their rich green foliage forms a perfect background for their hues.

We furnish large, strong, plump roots, the most vigorous size for blooming.

COURONNE D'OR. Immense ball-shaped blooms, snowy white with golden stamens. Late. $90 \mathrm{cts}$. each.

DUCHESSE DE NEMOURS. Early fragrant sulphur-white. Vigorous grower. Free bloomer. 75 cts. each.

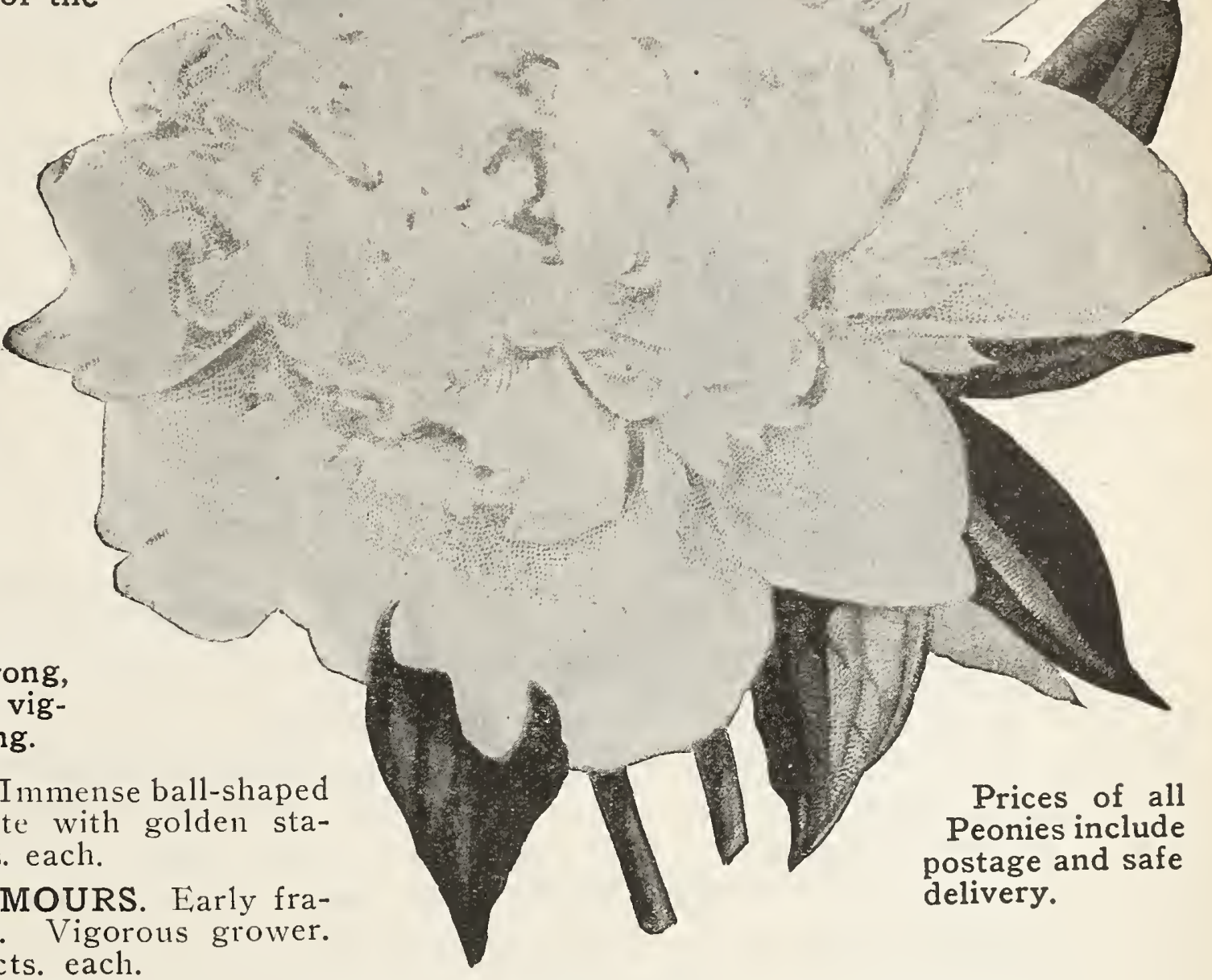

EDWARD ANDRE. Deep brilliant crimson red, shaded black, very large blooms, strong grower. Mid-season. Earliest of the dark reds. $90 \mathrm{cts}$. each.

*EDULIS SUPERBA. Light pink with silver shadings, one of the earliest and best, great favorite for Memorial Day. Very fragrant. 75 cts. each.

*FELIX CROUSSE. Brilliant red, fine large blossoms. Delightful fragrance, bright and effective. Considered the finest red Peony. $\$ 1.25$ each.

*FESTIVA MAXIMA. The best white Peony. Pure snow-white with a fleck of carmine in the center. 75 cts. each.

*FRAGRANS. Solferino-red with silvery reflex. Compact full flowers. Strong and vigorous. Extensively grown for cut-flowers. 75 cts. each.

LIVINGSTONE. Fine soft rosy pink, large, measuring occasionally 8 to 9 inches. Fragrant, blooms freely. Excellent for cutting. Crousse's masterpiece. $\$ 1.25$ each.

MONS. JULES ELIE. Pale rosy-lilac, very large, measuring occasionally 8 to 9 inches. Early. Delightful fragrance. Blooms freely. Fine for cutting. $\$ 1.50$ each.

OFFICINALIS RUBRA-PLENA. Best known, earliest to bloom Red Peony, producing freely brilliant, glowing, double crimson blooms. $\$ 1.00$ each.

*ROSEA PLENA SUPERBA. Delicate pink and salmon blooms, flowers very full. Good grower, fine for cutting. 90 cts. each.

ROSEA SUPERBA. Compact blooms of brilliant deep cerise-pink, perfectly formed. Excellent for cutting. $\$ 1$ each.

COLLINS PEONY OFFER: One each of above starred (*) Peonies, making five in all (all different, whole color range represented) for $\$ 3.35$ postpaid. Regular value if purchased singly, \$1.40.

Double Peonies Mixed. Good strong roots. Red, pink or white in choicest mixture 50 cts. each; $\$ 5$ per doz.; $\$ 35$ per 100 . 


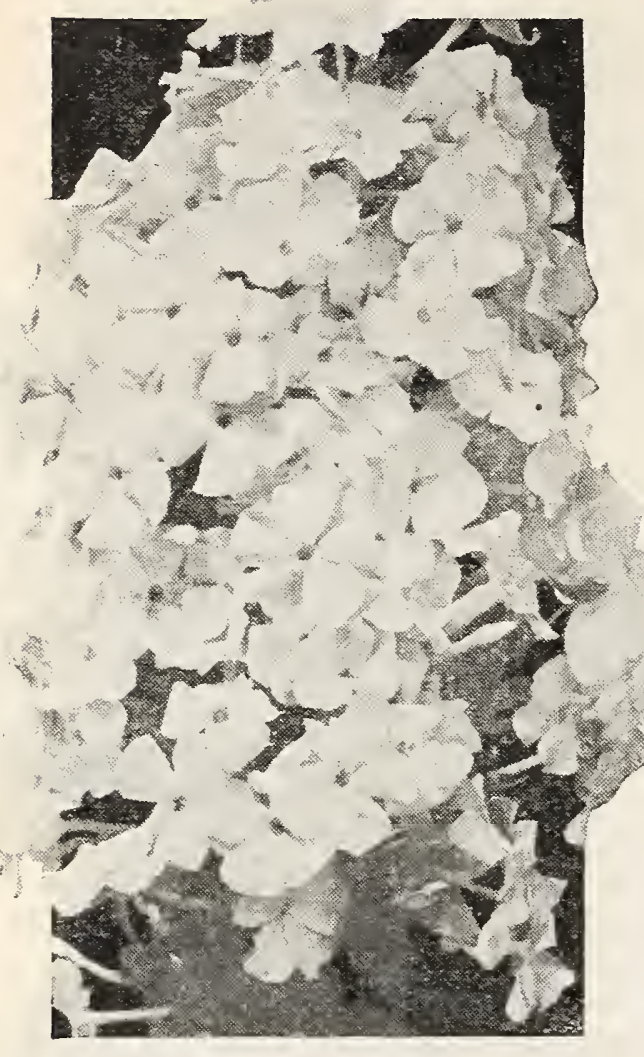

Phlox-often 12 in. long

\section{HARDY PHLOX Summer's}

One of the most valuable Perennials. Fine for massing with its mixed colors and fine habits. Wide color range. Profusion of blooms over very long season. June to October. Use in masses 2 to $4 \mathrm{ft}$.

ALBION. White with faint red eye.

ANTOIN MERCIER. Soft lilac blue, white center.

BACCHANTE. Fiery pink, crimson eye.

BARON VON DEDEM. Brilliant cochineal-red, with salmon shadings.

BEACON. Bright sparkling cerise.

GEFFION. Soft pink with soft rose eye.

LA VOGUE. Rosy pink.

MRS. JENKINS. Pure white; large.

ROSENBERG. Carmine violet with reddish eye.

R. P. STRUTHERS. Rosy red with crimson eye.

THOR. Very large trusses of dazzling salmon pink flowers, overlaid with a scarlet glow. 30 cts. each; $\$ 3.00$ per doz.

WIDAR. Light reddish violet with large white center.

Price of above Phlox, except where noted, 25 cts. each; $\$ 2.50$ per doz.; $\$ 15$ per 100 .

SPECIAL OFFER: 1 of each of above 12 kinds for $\$ 2.25$ 24 ( 2 of each kind) $\$ 4.00$ postpaid.

MISS LINGARD. This most excellent white Phlox starts blooming in May and continues through October. One of the most popular sorts grown. Especially good for cutting. 3 plants for 80 cts.; per doz. $\$ 3.00$.

\section{PHYSALIS (Chinese Lantern Plant or Winter Cherry)}

FRANCHETTI. Bright orange lantern-like cases, each containing a cherry-like fruit. Valuable for drying for winter decoration. $2 \mathrm{ft}$. October. 3 for $65 \mathrm{cts}$; per doz. $\$ 2.50$.

\section{PYRETHRUM (Persian or Painted Daisy)}

Excellent for cutting. Stems nearly $2 \mathrm{ft}$. high. Daisy-like flowers, 2 in. across, ranging from pure white through pink to rich crimson-red; also pale yellow with bright yellow centers. Continuous picking brings more blooms. Excellent in masses. July and through late summer. All colors in mixture. 3 plants for 65 cts.; per doz. $\$ 2.50$.

\section{RANUNCULUS (Buttercup)}

REPENS FL. PL. This popular double Buttercup bears myriads of cheerful golden yellow flowers, bright and pleasing. May and June. Valuable for cutting. 18 in. high. 3 plants 65 cts.; per doz. $\$ 2.50$.

\section{STOKESIA (Cornflower Aster)}

CYANEA. This beautiful plant bears large double purple-blue flowers, resembling China asters, sometimes 4 inches or more across. Blooms from July to November. Fine for use as cutflowers. 1 to $2 \mathrm{ft}$. 3 plants for $65 \mathrm{cts}$; per doz. $\$ 2.50$.

\section{TRITOMA (Red Hot Poker, Torch Lily)}

PFITZERI. The extremely brilliant flower spikes of this muchprized bedding plant make it striking in masses, and in front of shrubs. Pointed spikes of rich orange-scarlet flowers, on erect stems. 3 to $t$ feet long. Gracefully curving leaves. Very free bloomer, fine for cutting. August to November. 3 plants for $85 \mathrm{cts}$; per doz. $\$ 3.50$.

\section{VERONICA (Speedwell)}

LONGIFOLIA SUBSESSILIS. Showy spikes of intense lavender-blue flowers 12 inches long, rising 2 to 3 feet high from fine, persisting green foliage. Fine naturalized with shrubs. July to October. 3 plants for 80 cts.; per doz. $\$ 3.00$.

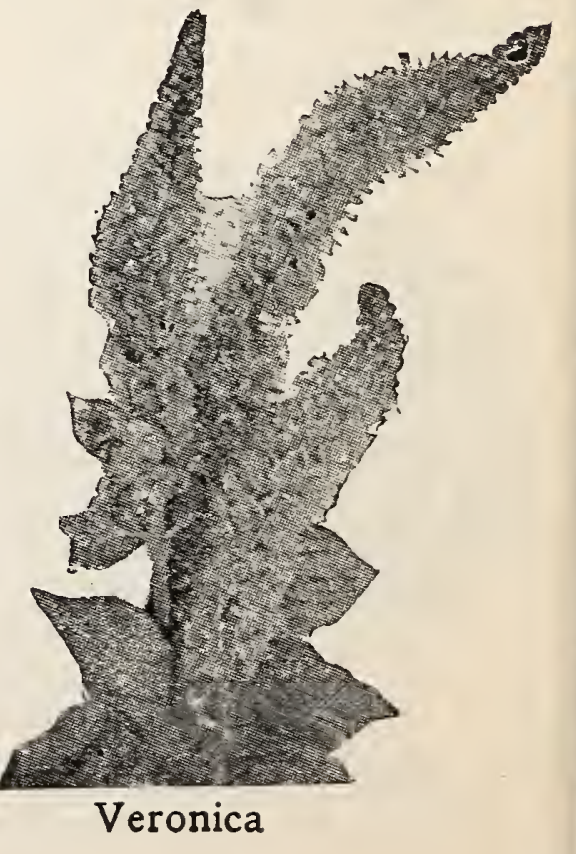




\section{VIOLA CORNUTA ('Tufted Pansy, Horned Violet)}

JERSEY GEM. This fine new acquisition to the beautiful Violas cannot be too highly praised. One of the best hardy plants of recent introduction, sturdy habit of growth. Blooms freely and continuously trom spring to winter. Flowers of royal purple on stems 6 inches long, making it splendid tor cutting. Use freely for edging and bordering paths. Excellent foliage. Early April to Dec. 3 plants $80 \mathrm{cts}$; per doz. $\$ 3.00$.

\section{Old Favorites, Largely Low Growing}

PHLOX, AMOENA. Splendid for carpeting ground, rockery or border. In spring is a sheet of bright pink flowers. 4 inches high.

PHLOX, DIVARICATA CANADENSIS. Large fragrant lavender flowers, from early April till late May. 10 inches high.

PHLOX. SUBLATA. (Moss or Mountain Pink.) Early spring flowering, the masses of biooms completely covering the moss-like evergreen foliage. Invaluable for carpeting ground. Lilacina, pale lilac. Rosea, rose. Vivid, warm salmon-rose. 6 in.

PLUMBAGO, LARPENTAE. Covered with deep blue flowers during summer and fall. Wonderful spreader. Most desirable for borders and rockeries. 6" to $8^{\prime \prime}$.

EUPATORIUM, COELESTINUM. Light blue flowers in dense heads August till frost. Hardy. 18 to 24 inches.

Prices of above, 3 for $65 \mathrm{cts}$; $\$ 2.50$ per doz.

\section{Shall we Plan Your Perennial Garden?}

Many have asked us to prepare plans for their properties, giving profusion of bloom at all periods and a pleasing color combination. So often have these plans brought us commendation, that we have decided to extend this service, which includes

First, a plan of the perennial garden so keyed that it is easy to plant.

Second, a general color effect of the planting recommended.

Third, a list of the plants called for by the plan, and an estimate of the

total cost of these, which you will find most moderate.

NO CHARGE is made for this service, the one dollar fee required (to avoid mere "curiosity" inquiries) with each request for plan, you deduct avoid from your payment for any perennials ordered to a value of $\$ 5.00$ or more. available and any existing plantings near it. Show North on plan.

\section{Collins "Perennial Pleasure" Border}

Excellent bed of fine proportions presenting a beautiful color scheme, from early spring until late frost. Good supply of flowers for cutting. Excellent along your lawn boundary.

Key Quan. Variety 52 Hibiscus. Pink.

13 Hibiscus, white

23 Digitalis, Gi a n t Shirley

35 Hollyhocks, double red

4 Asters, Perry's 109 Delphinium BellaWhite

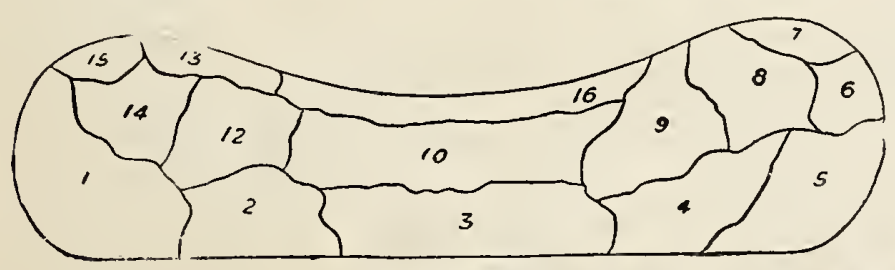

123 Chrysanthemums,

133 Viola Cornuta

$141 \mathrm{P}$ e o n y, Edward Andre

153 Tritoma Pfitzeri

163 Papaver assorted

Total, 50 plants,

Value, $\$ 13.30$

\section{Furnished}

complete,

postpaid,

(Beyond Mississippi add 25 cents)

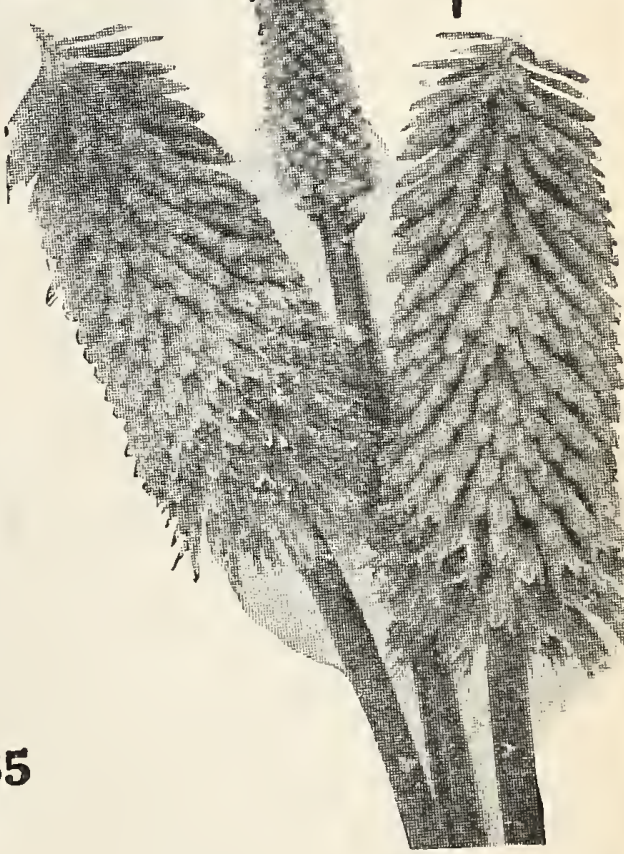

Tritoma
Mighty Like a Rose-Opening Theme

Scarf Dance

Only a Rose (Vocal)

Garden of Roses

Roses of Love (Vocal)
Bring Me a Rose from the Arcadians Helpful Talk on Rose Culture Serenade Red Rose from Ballet of the Flowers Mighty Like a Rose-Closing Theme 


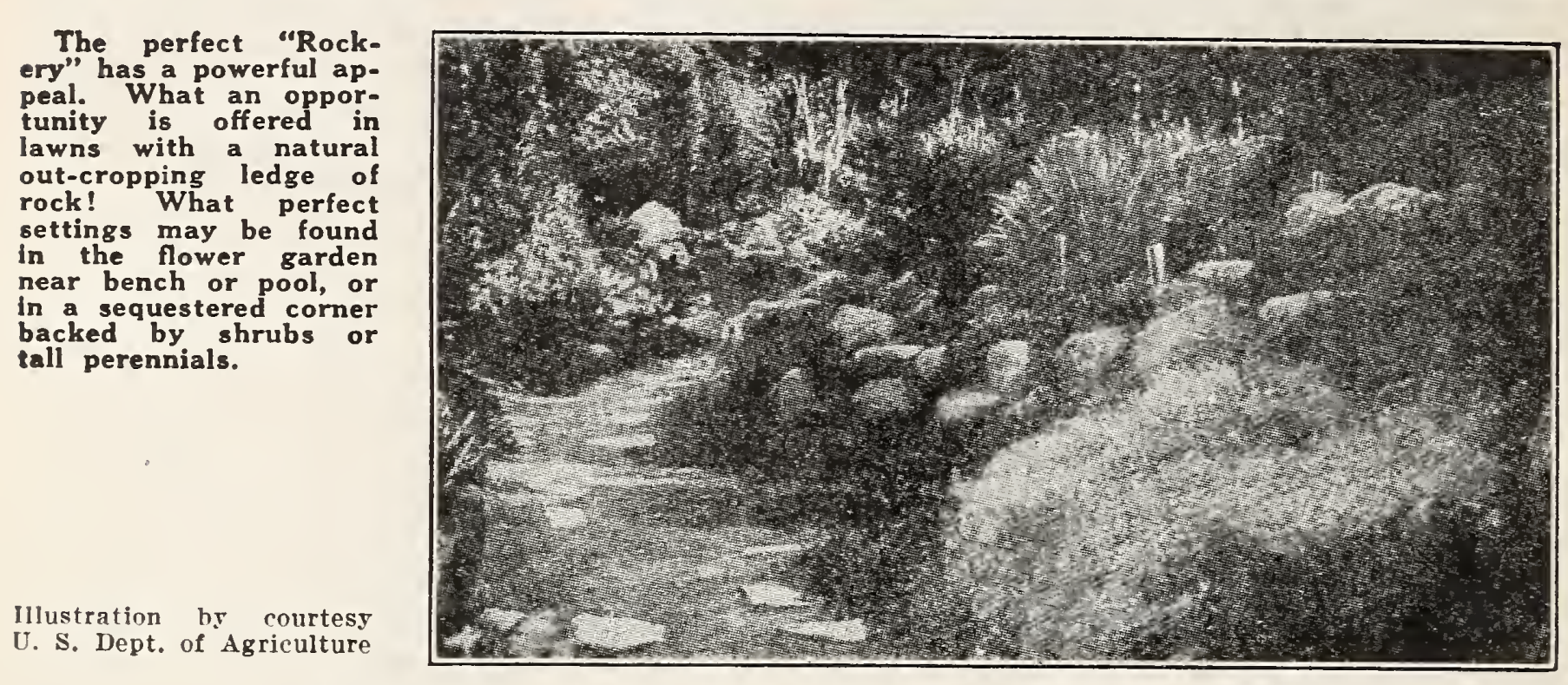

\section{Plants for the Rock Garden}

Interest in these dainty rock plants is increasing rapidly, first because they have a singular fascination for all who come within their spell; second because, once started, they spread over the stones without further care, except an occasional pulling of stray weeds, and watering during unusually hot, dry weather.

Coming from stony ledges high on Alpine mountain sides, these plants are naturally at home and actually thrive best in poor soil, unaffected by weather extremes. They clothe the rocks in long streaming waves of foliage of varied formation in gray, red, green and bronze- and gay flowers of blue, pink, white, red, purple and yellow. Most
of them hold their leaves all winter, despite frosts and bitter cold.

SPECIAL OFFER: A remarkable collection of hardy 50 ROCK GARDEN PLANTS All plants are labelleded from our 16 unusual, rare varieties, $\$ 9.75$ express prepaid. All plants are labelled and may be set out in groups over the Rockery as you choose. Once planted you have a permanent ROCK GARDEN which will grow more pleasing
year after year.

OFFER “B": Contains 25 ROCK GARDEN plants from 8 varieties for $\$ 5.45$, by express prepaid to any address. All labelled as in the larger collection above.

\section{COLLINS ROCK GARDEN VARIETIES}

(Flowers throughout the entire season. Heaviest flowering months are indicated below. Even when not in bloom the plants are a most interesting study.)

IRIS PUMILA. Violet-purple flowers. May.

VERONICA RUPESTRIS. Deep blue, trailing. June.

DIANTHUS ARENARIUS. Deeply fringed white flowers. May-June.

TUNICA SAXIFRAGA. Grass-like foliage; rosy-pink flowers. June-September.

PHLOX AMOENA. Vivid pink flowers. April-May.

VERONICA INCANA. Silvery foliage, deep blue flowers. May-June.

ACHILLEA TOMENTOSA. Bright yellow flowers. May-June.

DIANTHUS DELTOIDES. Dark green foliage, with exquisite crimson, or white, or
pink flowers. June-July.

ALYSSUM SAXATILE COMPACTUM. Masses of yellow flowers. April-May. SAPONARIA OCYMOIDES. Trails over the rocks spangled with bright pink flowers
through the spring.

SEDUM ALBUM. Handsome foliage, turning red in the fall; white flowers. June-July.

SEDUM ACRE. Carpet of vivid green foliage, hidden by yellow flowers in May.

CALAMINTHA ALPINA. Clusters of violet-blue flowers. July-August.

CERASTIUM TOMENTOSUM. Silvery foliage, pure white flowers. May.

ARMERIA MARITIMA LAUCHEANA. Grass-like foliage in compact bunches, entirely covered with globular heads of pink flowers. May-June. GYPSOPHILA REPENS. Excellent for cascading down the slopes of the Rock
Garden. Masses of tiny white flowers. June-July. 


\section{Collins Cannas}

\section{Large Flowering Types}

Cannas make a gorgeous show of bright blooms from early summer until cut down by frost in the fall. Their various shades of foliage deep green, and rich bronze, add greatly to their beauty. Very effective in masses of one color or assorted. Moderate in price, easy to grow, gorgeous in bloom-these are only a few of the features that account for Cannas rapid increase in popularity.

Note: We furnish started plants in pots for delivery after danger of frost is passed in the spring (probably May), giving the plants a good start for a fine long season of bloom. Set the plants about 24 in. apart. You will get great satisfaction from them on account of their long season of bloom, and their rich variety of colors.

\section{COLLINS "SELECT DOZEN" CANNAS}

CHEERFULNESS. Deep rich, bright orange flowers bordered with golden yellow and carmine markings. Foliage is thick and massive, above which striking flowers are borne on large, heavy trusses. $31 / 2$ feet.

EUREKA. Exceptionally beautiful, large, pure white flowers. The best white of all the Cannas, produced abundantly on vigorous strong stalks and in large trusses. $4 \mathrm{~T} / 2 \mathrm{ft}$.

FRAU DR. KLIEN. A very brilliant carmine-red, growing in large trusses beautifully formed on tall, strong stalks. The flowers are beautifully formed and are produced very freely, petals of sturdy character. $5 \mathrm{ft}$.

GENERAL MERKEL. Flowers very bright scarlet with a brilliant golden yellow suffusion; edges splashed golden-yellow. Foliage green. 4 - feet.

HARMONY. Brilliant flowers of carmine-red, very bright. Formed in huge clusters and set amid highly colored bronze foliage. Especially attractive in groups. $31 / 2 \mathrm{ft}$.

KING HUMBERT. This kingly Canna is a great grower, reaching a height of 5 feet. It has massive trusses of orange-scarlet flowers; foliage is beautiful deep bronze.

LAHNECK. Its lovely flowers are a rich combination of carmine-rose and scarlet, with a neat, narrow golden border. 4 feet.

RICHARD WALLACE. A very showy pure bright canary-yellow, without doubt the best yellow Canna. Flowers very large and well-formed, borne on strong stalks. $5 \mathrm{ft}$.

THE PRESIDENT. A splendid new variety, and without doubt the greatest scarlet Canna, producing immense flowers of rich, glowing scarlet of enormous size. Spectacular in thickness of growth and brilliance of color. 5 feet.

UHLBERG. Soft, rosy-carmine with cream-yellow at throat and edges of petals. Flowers open up well. Foliage green. $31 / 2$ feet.

WYOMING. Beautiful color combinations are produced by the massive orangechrome flowers and bronze-purple foliage. 6 feet.

YELLOW KING HUMBERT (QUEEN HELEN). A sport of the bronze-leaved red KING HUMBERT. Its orchid-like flowers, produced in enormous masses, are golden-yellow with orange-red dots. Green foliage. (Occasionally a stalk reverts to the typical King Humbert of bronze foliage and orange-scarlet flowers.) $4 \mathrm{x} / 2$ feet.

Prices of above Cannas, each, 35 cts.; $\$ 3$ per 10, postpaid. By express, $\$ 20$ per 100 .

SPECIAL OFFER: One each of the above 12 kinds (12 plants in all), for $\$ 2.95$, postpaid. (West of Mississippi River, add $25 \mathrm{cts}$. for postage.) 
SWEET LAVENDER. Pale lavender with deeper lavender throat markings. $25 \mathrm{cts}$. each; $\$ 2.50$ per doz.

SERRATA. One of the rarest of novelties with the edges of the petals serrated. Pale yellow with blends of salmon and cream. 35 cts. eacli; 3 for $\$ 1.00 ; \$ 3.50$ per doz.

VIOLET BEAUTY. Very tall, growing large cerise-violet colored flowers, beautifully formed with red throat blotches. Two and three flowers on one stem usually appear, which is unusual for Glads. 35 cts. each; 3 for $\$ 1.00 ; \$ 3.50$ per doz.

SPECIAL OFFER: One each of the above 10 finest and newest creations for $\$ 3.25$ postpaid. The unusual color blendings and remarkable hab:ts of growth make this collection one of the best and most popular. 3 of each (30 bulbs in all), $\$ 8.95$ postpaid.

\section{Choice and Rare Gladiolus}

ALBANIA. The only white to receive a first-class certificate from the American Gladiolus Society! Purest glossy white, most pleasing of all white varieties. Its wide-open flowers measure 4 inches or moie across; petals are broad, with wellrounded tips. Finely ruffled edges give an aristocratic finish. Flowers are ideally placed on the spike. Vigorous grower. 35 cts. each; 3 for $\$ 1.00 ; \$ 3.50$ per doz.

DORRITT. A rare combination of colors-white blended by pale orchid-lavender, excellently striped and splashed rosered. Very desirable. 35 cts. each; 3 for $\$ 1.00 ; \$ 3.50$ per doz.

DR. F. E. BENNETT. Brilliant flame-scarlet, most perfect red. Throat markings are deep peach-red, speckled ruby and white. Large flowers, many open at once. 50 cts. each: $\$ 5.00$ per doz.

FERN KYLE. Extraordinary new variety introduced at $\$ 25.00$ per bulb. One of the finest ruffled creations, soft creamy white. Flowers of unusually large size, great beauty and perfection of form. $50 \mathrm{cts}$. each; 3 for $\$ 1.50$.

GOLD. Beautiful pure yellow. One of the very finest. 25 cts. each; 6 for $\$ 1.25 ; \$ 2.50$ per doz.

LOELLA. One of the finest of autumn tints, a rare blend of old-rose, flecked deep smoky blue, much desired by Gladiolus enthusiasts. Very rare. 75 cts. each; 3 for $\$ 2.00$.

MR. W. H. PHIPPS. Enormous flowers of LaFrance pink, overlaid light rose-salmon. Lower petals faintly striped ruby. Exceptionaily fine. $50 \mathrm{cts}$. each; 3 for $\$ 1.50$.

MURIEL. Exceptionally fine shade of blue, with bluishlavender and violet throat markings. Most desired by Glad enthusiasts. $35 \mathrm{cts}$. each; 3 for $\$ 1.00 ; \$ 3.50$ per doz.

REV. EWBANK. Rare, rich, porcelain blue with lavender shadings. Most desirable blue shade. $20 \mathrm{cts}$. each; $\$ 2$ per doz.

RICHARD DIENER. A sensational California production, with a rare blending of geranium-pink and a delicate speckling of ruby in its creamy-yellow center. 50 cts. each; $\$ 5.00$ per doz. (See photo.)

SPECIAL OFFER: One each of the above 10 varieties (10 bulbs in all), $\$ 3.80$ postpaid. Many are rare and are still listed under others growers' catalogues as the newest. 3 of each variety (30 bulbs in all), $\$ 10.90$ postpaid. 6 of each variety (60 bulbs in all), $\$ 20.60$ postpaid.

\section{Collins 40-Bulb 8-Color $\$ 1.00$ Offer}

Forty blooming-size bulbs (5 each of 8 different colorsorchid, white, salmon, dark red, yellow, blotched, pink and pastel shades), $\$ 1.00$ postpaid. Large, blooming stalks, with many flowers on each spike. Bulbs $1 / 2$ to 1 inch in diameter. ( $\mathrm{In}$ this collection only.) 


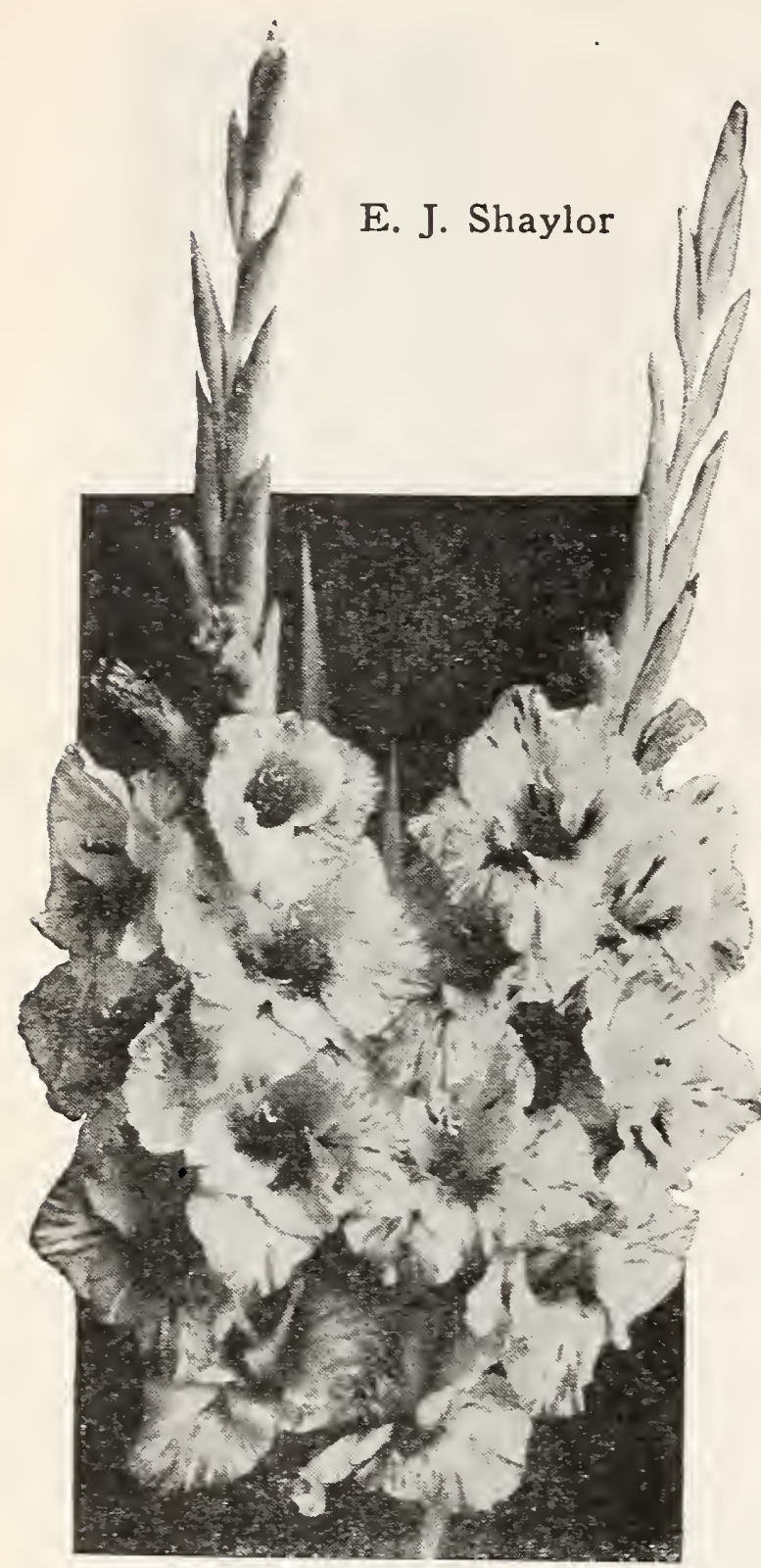

\section{Ruffled Gladiolus}

ALTON. A most unusual shade of orange, with deeper orange throat markings. Entirely different from any other variety. $25 \mathrm{cts}$. each; $\$ 2.50$ per doz.

ANTHONY B. KUNDERD. Tall, intensely ruffled deep cream, overlaid blush-pink, lower petals primrose-cream. 35 cts. each; 3 for $\$ 1.00 ; \$ 3.50$ per doz.

E. J. SHAYLOR. One of the finest. Deep rose-pink to rose, throat of lower petals pencilled rose-red. Vigorous. Popular cut-flower. 15 cts. each; $\$ 1.50$ doz.

GOLDEN GLORY. Large primrose-yellow, with cream markings in throat and conspicuous red blotch. Exquisitely ruffled. $25 \mathrm{cts}$. each; $\$ 2.50 \mathrm{doz}$.

MARIE KUNDERD. Grandest of all ruffled whites. Blooms very early. Purest white flowers of great beauty with faint pink line in center of lower petals. 35 cts. each; 3 for $\$ 1.00 ; \$ 3.50$ per doz.

NEOGA. Dark garnet-red with deeper throat. One of the best ruffled reds and much in demand. $15 \mathrm{cts}$. each; $\$ 1.50$ per doz.

ORANGE GLORY. Rich, deep orange, with lighter throat, the whole flower richly colored. Sturdy grower. 15 cts. each; 3 for 40 cts.; $\$ 1.50$ per doz.

PINK LILY. Deep rose-pink. 25 cts. each; $\$ 2.50$ per doz.

PURPLE GLORY. Giant, beautifully ruffed, deepest velvety maroon-red, with almost black blotches. Extraordinary. 35 cts. each; 3 for $\$ 1.00 ; \$ 3.50$ per doz.

REMEMBRANCE. Geranium-pink, rose-doree on outer edges; throat blotched pomegranate-purple, slightly ruffled. Vigorous. 25 cts. each; $\$ 2.50$ per doz.

ROSE GLORY. Very large, beautifully ruffed. Deep rose-pink, deeper throat. Oile of the finest Ruffled Gladiolus. 25 cts. each; $\$ 2.50$ per doz.

VIOLET BEAUTY. Very tall, growing large cerise-violet, beautifully formed flowers, with red throat blotches. 35 cts. each; 3 for $\$ 1.00 ; \$ 3.50$ per doz.

SPECIAL OFFER: The above 12 best newest Ruffled Gladiolus, each with distinct merit, $\$ 2.85$ postpaid; 3 of each variety (36 bulbs in all), $\$ 8.25$ postpaid; 6 of each variety (72 bulbs in al1), $\$ 15.50$ postpaid.

\section{Primulinus Hybrids (or Graceful Gladiolus)}

ALICE TIPLADY. A beautiful blend of coppery-bronze and orange; in great demand. 10 cts. each; $\$ 1.00$ per doz.

GOLD DROP. Marguerite-yellow, deepening to primrose-yellow in the throat, with slight markings of amaranth-purple. $10 \mathrm{cts}$. each; $\$ 1.00$ per doz.

JEWEL. Beautiful salmon-pink, wth a clear golden-yellow throat. Very dainty. 15 cts. each; 3 for 40 cts.; $\$ 1.50$ per doz.

MYRA. Very large salmon-pink, with yellow throat markings. One of the largest of this graceful class. $10 \mathrm{cts}$. each; 3 for $25 \mathrm{cts}$; $\$ 1.00$ per doz.

SALMON BEAUTY. One of the daintiest of all the excellent growers; exquisitely formed. Salmon with yellow throat. $15 \mathrm{cts}$. each; 3 for $40 \mathrm{cts}$.; $\$ 1.50$ per doz.

SPECIAL OFFER: One each of the above $5 \mathrm{kinds}, 50 \mathrm{cts}$. postpaid. This interesting group, originated in South America, bears orchid-like, brilliantly colored flowers on strong, high spikes. As cut-flowers, their grace and form is unsurpassed. 3 of each variety ( 15 bulbs in all), $\$ 1.35$ postpaid; 6 of each variety (30 bulbs in all), $\$ 2.40$ postpaid. DAINTY PRIMULINUS MIXTURE. Pastel shades. 35 cts. per doz.; 3 doz. for \$1.00. 


\section{Select Gladiolus}

ANNA EBERIUS. Dark velvety purple, large, highly ruffed flowers. Vigorous. $15 \mathrm{cts}$. each; $\$ 1.50$ per doz.

BETTY JOY. Apple blossom pink, with cream throat marking. Very dainty. $20 \mathrm{cts}$. each; $\$ 2.00$ per doz.

DIENER'S WHITE. Many massive flowers open at once. Milk white with a trace of pink in throat. Strong grower. Best late white. $25 \mathrm{cts}$. each; $\$ 2.50$ per doz.

EMPRESS OF INDIA. Closest to black. A rich velvety maroon-black. Excellent. $15 \mathrm{c}$ each; $\$ 1.50$ per doz.

EVELYN KIRKLAND. Large, wide-open flowers of rose-pink, blending to shell-pink in the center, with brilliant splash of scarlet on lower petals. Long spikes, graceful flowers, very large. $15 \mathrm{cts}$. each; $\$ 1.50$ per doz.

GRETCHEN ZANG. Large flowers of salmon-pink, blending to scarlet. $10 \mathrm{cts}$. each; $\$ 1.00$ per doz.

NIAGARA. Exquisite soft yellow, best in this color Vigorous. $15 \mathrm{cts}$. each; 3 for $40 \mathrm{cts} ; \$ 1.50$ per doz.

PEACE. Gigantic white flowers on magnificent spikes, with stripe of purple-carmine through lower petal. Very late. 10 cts. each; $\$ 1.00$ per doz.; $\$ 7.50$ per 100 .

SCARLET PRINCEPS, or VIRGINIA. Six or more massive brick-red blooms open at once, their throats deeper red, with white markings. Blooms set close on massive spikes. $25 \mathrm{cts}$. each; $\$ 2.50$ per doz.

SCHWABEN. Striking canary-yellow, with a blotch of brilliant carmine deep in its golden throat. Excellent in beds. 10 cts. each; $\$ 1.00$ per doz.; $\$ 8.00$ per 100 .

SPECIAL OFFER: One each of the above 10 kinds (10 bulbs in all), $\$ 1.40$ postpaid. The leaders of the older "Standard" Sorts. Many firms list some of these among their newest sorts. 3 of each variety (30 bulbs in all), $\$ 4.00$ postpaid; 6 of each variety (60 bulbs in all), $\$ 7.65$ postpaid.

\section{Standard Gladiolus}

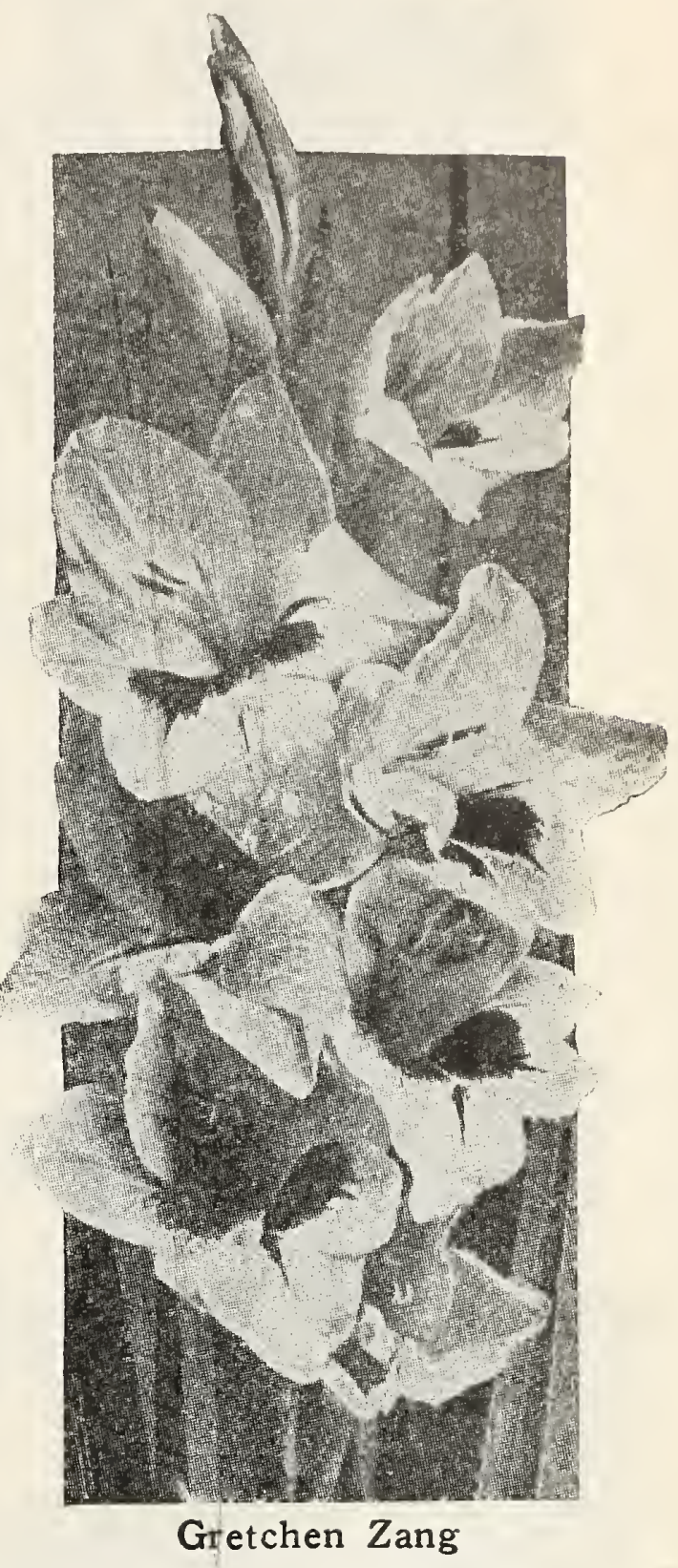

AMERICA. Acknowledged "King of Gladiolus." Gigantic flowers of lavender-pink. 10 cts. each; 50 cts. per doz.

CRIMSON GLOW. The best inexpensive red on the market. Very large. 10 cts. each; 75 cts. per doz.

HOPEWELL WHITE. Pure white. Many flowers bloom at once. 10 cts. each; $\$ 1.00$ per doz.

LE MARECHAL FOCH. Pure, delicate, lily-like flowers of rose-pink. Petals very broad. $10 \mathrm{cts}$. each; $50 \mathrm{cts}$. per doz.

MEADOWVALE. White with red throat markings. 10 cts. each; $\$ 1.00$ per doz.

MISS HELEN FRANKLIN. A well-ruffled white, with' a blotch of rhodamine-purple in the throat. Good cut-flower variety and propagator. $10 \mathrm{cts}$. each; $\$ 1.00$ per doz.

MRS. FRANK PENDLETON. A large, beautiful, stately bloom, salmon-pink, rich maroon blotch on lower petals. Vigorous. $10 \mathrm{cts}$. each; $\$ 1.00$ per doz; $\$ 8.00$ per 100 .

MRS. WATT. Glowing wine-crimson. A most beautiful dark flower, distinct in coloring. 10 cts. each; $\$ 1.00$ per doz.; $\$ 8.00$ per 100 .

PANAMA. Deep pink. Large flowers, long spikes. 10 cts. each; $\$ 1.00$ per doz.; $\$ 8.00$ per 100.

PRINCEPINE. Brilliant, attractive color combination of carmine-red, with large white blotch; most conspicuous. $10 \mathrm{cts}$. each; $50 \mathrm{cts}$. per doz.

SPECIAL OFFER: One of each of the above 10 kinds (10 bulbs in all), 90 cts. postpaid. This group covers the entire color range and some of the best of the Standard varieties and is built to meet all tastes and requirements. 3 of each variety ( 30 bulbs in all), $\$ 2.50$ postpaid; 6 of each ( 60 bulbs in all), $\$ 4.75$ postpaid. 


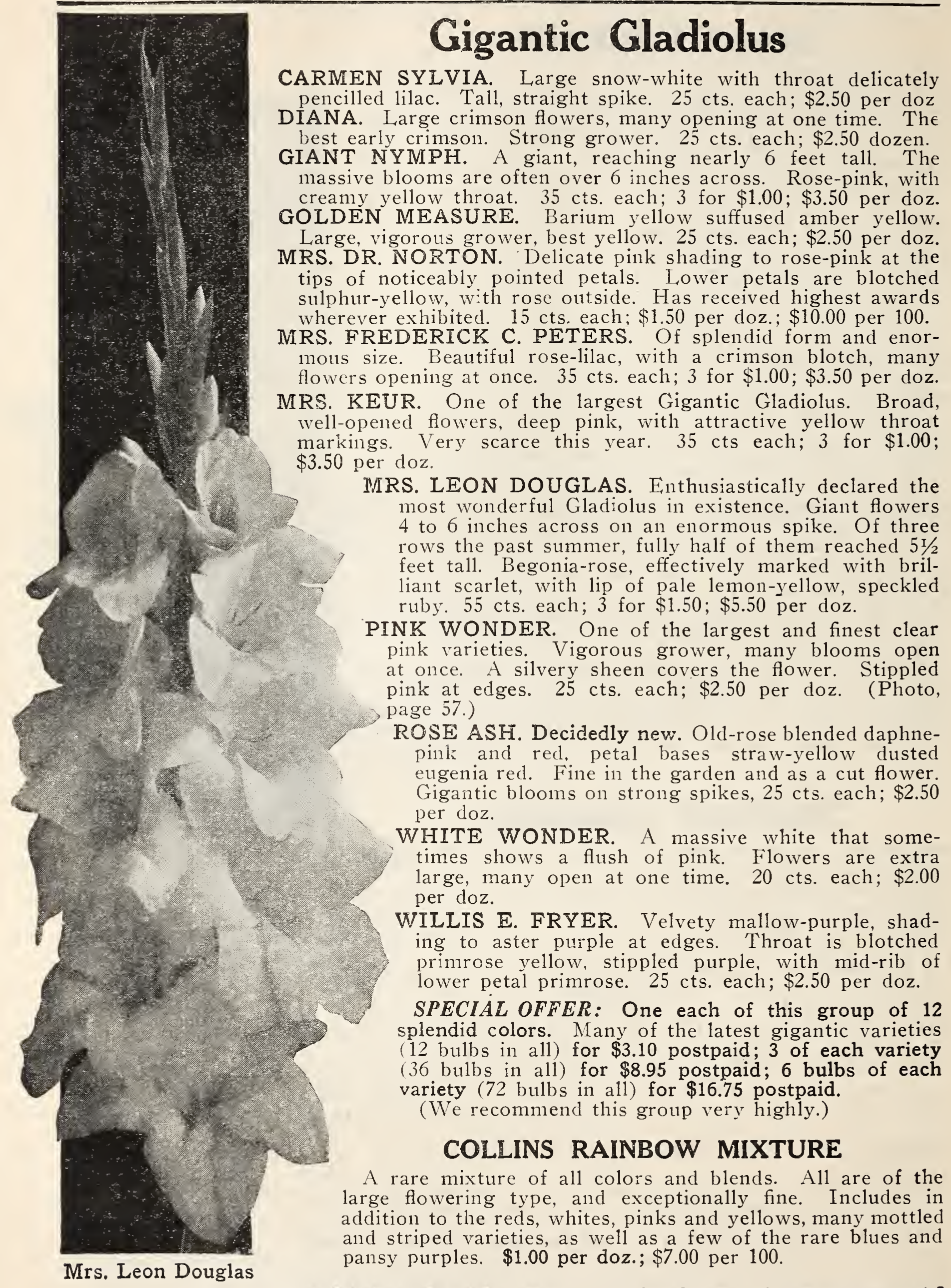

SURPRISE MIXTURE— 60 bulbs for $\$ 1.95$ postpaid

A very good combination including some of the large flowering varieties as well as the dainty Primulinus Hybrids. Wide color range. 50 cts. per doz.; $\$ 3.25$ per 100 . 


\section{Early Flowering Gladiolus}

There are but few early Glads. In this list are all the worthwhile varieties. Notice our fine color range.

ALICE TIPLADY. A beautiful blend of coppery bronze and orange; in great demand. $10 \mathrm{cts}$. each; $\$ 1.00$ per doz.

DIANA. Crimson. See page 56.25 cts. each; $\$ 2.50$ per doz.

HALLEY. Salmon-pink. Large, open flowers. Tall, very early and prolific. $10 \mathrm{cts}$. each; 75 cts. per doz.; $\$ 6.00$ per 100 .

HERADA. Large orchid-lavender flower, well placed on strong, straight spikes. 15 cts. each; $\$ 1.50$ per doz.; $\$ 10.00$ per 100 . MARIE KUNDERD. Purest white. See page 54.

MARY PICKFORD. A delicate creamy-white, throat markings of soft sulphur-yellow; considered by many the best early white. 15 cts. each; 3 for 40 cts.; $\$ 1.50$ per doz.

NEOGA. Garnet-red. See page 54. $15 \mathrm{cts}$. each; $\$ 1.50$ per doz. PRINCE OF WALES. Blended salmon and orange. A rare and desired color combination. 10 cts. each; $\$ 1.00$ per doz. WILBRINK. Livid pink, lower petals have a light purple blotch on yellow. $10 \mathrm{cts}$. each; $75 \mathrm{cts}$. per doz.; $\$ 7.00$ per 100 . 1910 ROSE. Beautiful deep salmon-rose, one of the earliest and most prolific. Very fine. $20 \mathrm{cts}$. each; $\$ 2.00$ per doz.

SPECIAL OFFER: One each of the above 10 kinds (10 bulbs in all), $\$ 1.45$ postpaid. Much desired by those who want color and abundance of early flowers. 3 of each variety, (30 bulbs in all), $\$ 4.00$ postpaid; 6 of each variety ( 60 bulbs in all), $\$ 7.50$ postpaid.

\section{Reliable Collection}

Every variety in this collection is a distinct color and has very large sized, long spikes with many flowers open at one time. The cream of the standard varieties - a trifle better than what most firms offer as standard. Supply on this collection limited to 25,000 bulbs.

HALLEY. Salmon giant, described above.

HERADA. Orchid-lavender, described above.

MARY PICKFORD. White, described above.

MRS. DR. NORTON. Pink and yellow. Described on page 56.

MRS. FRANK PENDLETON. Blotched salmon and pink, described on page 55 .

NEOGA. Ruffled dark red, described on page 54.

WILBRINK. Early pale pink, described above.

1910 ROSE. Vivid rose, described above.

\section{EIGHT DISTINCT COLORS (all postpaid)}

3 of each (24 bulbs) for $\$ 1.50$

12 of each ( 96 bulbs) for $\$ 5.00$

6 of each ( 48 bulbs) for 2.95

25 of each (200 bulbs) for 10.00

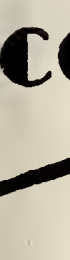

\section{$\mathrm{M}$
$\mathrm{R}$
$\mathrm{L}$
$\mathrm{H}$}

Mi
Theme

Roses, Roses Everywhere-(Vocal)

Les Roses

Helpful Talk on Rose Culture

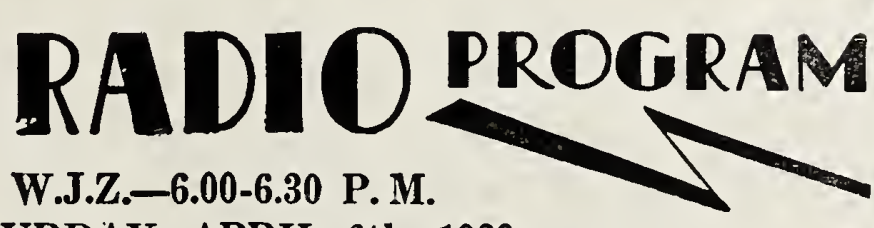

W.J.Z.-6.00-6.30 P.M.

SATURDAY, APRIL 6th, 1929

Rose-Opening When You Look in the Heart of a Rose (Vocal)

A Bunch" of Roses-Legend of a Rose

Mighty Like a Rose-Closing Theme

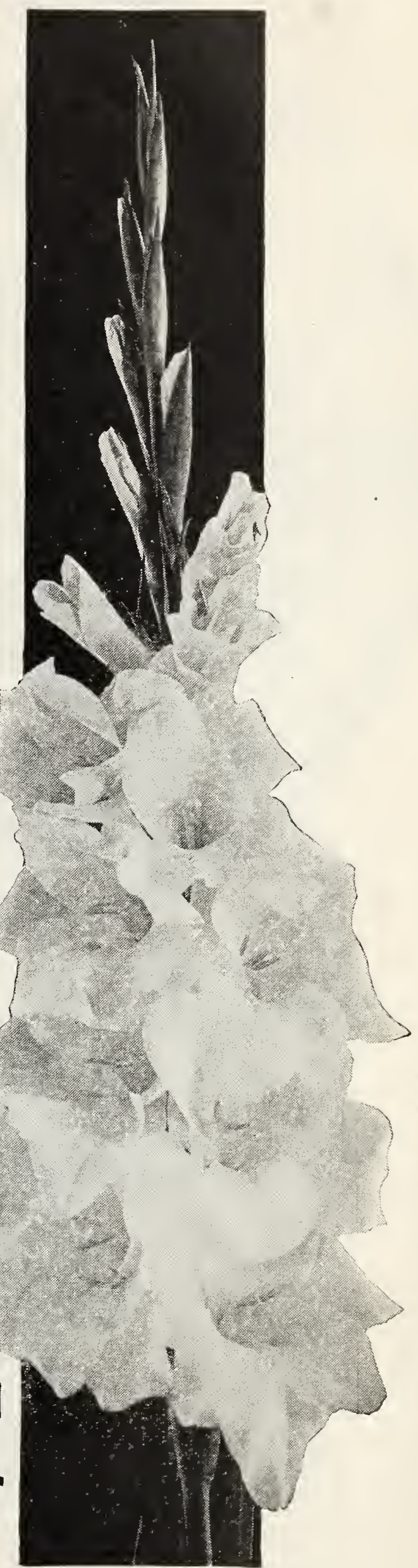

Pink Wonder (described on page 56)

For Radio Program of following week, see page 68 


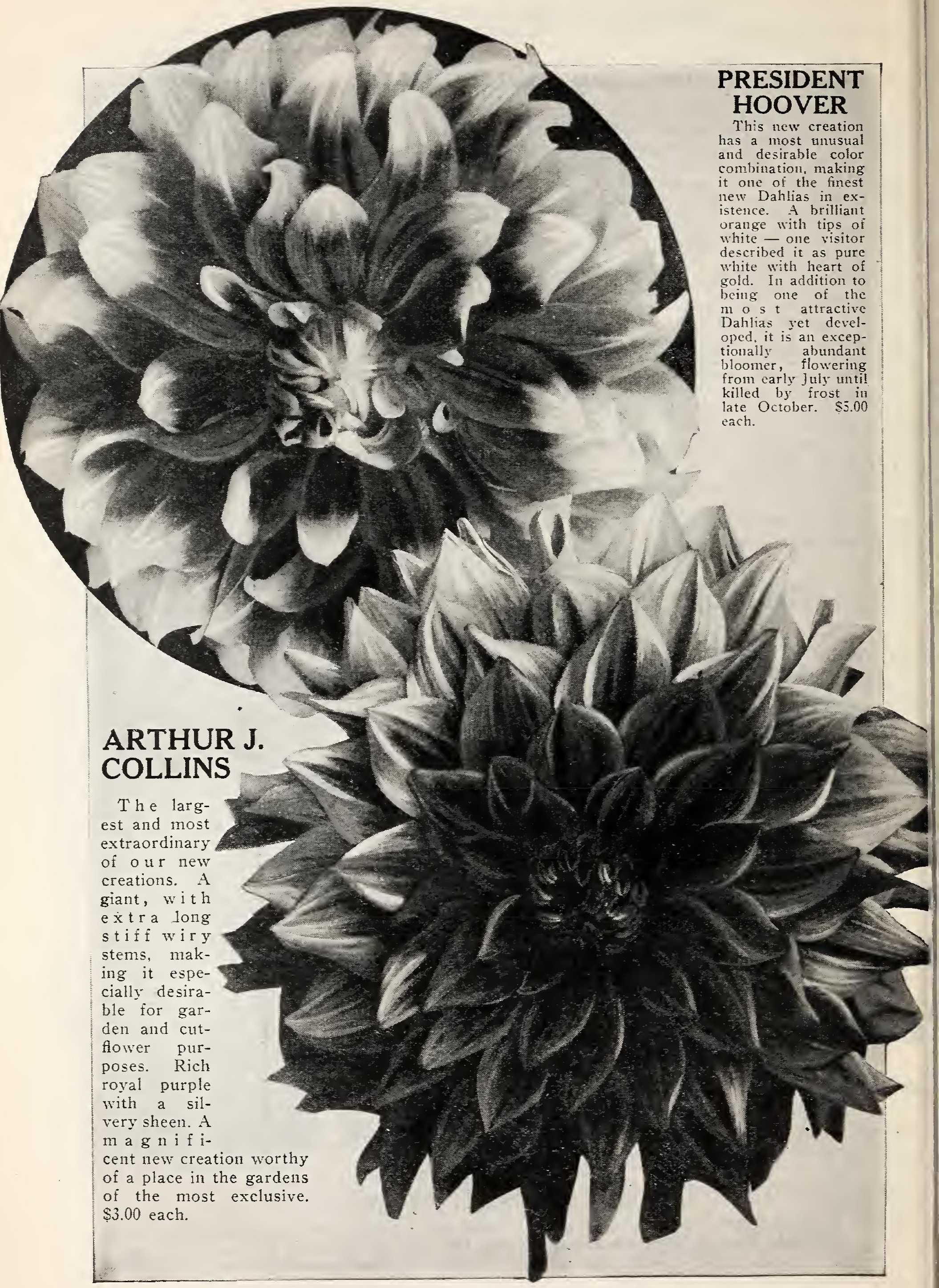




\section{Collins Best Grade Dahlias GUARANTEED TO GROW}

We confine our Dahlia offerings to those few with outstanding merit-in color, size, unusual shape, and particularly with regard to the keeping qualities of the tubers over winter. Our policy in thus limiting our varieties and offering them to you in groups has resulted in many letters of praise over the magnificent blooms from these collections.

The new dahlias listed this year are exceptional creations (note particularly the two illustrated on opposite page). On the later dahlia pages, you will find the outstanding varieties which have stood the test of time. (See also our color plate offer on page 76.) All have been thoroughly proven and are recommended as the best of their color and kind obtainable.

We supply you with dormant, field-grown roots or generous divisions of fullymatured field-grown clusters; strong, healthy, plump, well-developed and full of vitality. And, as an added protection to you, we guarantee every tuber to grow, and will replace FREE, on proper proof, any that fail to sprout.

The Dahlia is the "Queen of Fall Flowers," starting to bloom in the summer and continuing from 10 to 18 weeks, or until cut down-by frost. The blooms you receive in a few short months from the roots you order now will stir your admiration and make you as enthusiastic as our other customers who have come within their spell.

\section{Collins Phenomenal New Dahlias for 1929}

A wonderful group, the foremost Dahlias of our entire collection. The kinds people order when they see them in bloom-the best test of any Dahlia.

AIDA. A continuous flowering new creation of beautiful formation, huge rich deep velvety crimson-maroon flowers upon long stiff stems. $\$ 1.00$ each, three for $\$ 2.75$.

ANDREAS HOFER. This new Holland importation is the finest of the modern Cactus Dahlias we have seen. A most delightful shade of rose-pink blending to yellow at the center. Exceptionally long stiff stems, so strong that it is the best for cutflower purposes we have seen among the newer creations. Exceptionally abundant, flowering continuously from early June until October frost. $\$ 3.00$ each.

ARTHUR J. COLLINS. Rich royal purple. See facing page.

CHIEFTAIN. Brilliant cherry-red. Some flowers orange-buff striped and splashed cherry-red. A rare novelty sure to satisfy. Exceptionally free-flowering. $\$ 1.00$ each.

GLORIANA. A great improvement over the old "King of the Autumn," the same beautiful orange-gold and bronze blend, but having a much longer stem and a larger, more beautiful flower. Very long stems, excellent when cut. $\$ 1.00$ each, 3 for $\$ 2.75$.

PRESIDENT HOOVER. Orange with white tips. See facing page.

SPECIAL OFFER: One strong selected tuber each of President Hoover, Arthur J. Collins, both described on opposite page, and Andreas Hofer, 3 tubers in all, for $\$ 9.85$ postpaid. One each of Aida, Chieftain and Gloriana, 3 tubers in all, for $\$ 2.75$ postpaid. Or one each (6 tubers in all) for $\$ 12.40$ postpaid. (Value $\$ 14.00$.)

\section{Collins Exceptional Dahlias}

MRS. ELMER O. DREW. First prize winner as the largest and best dark red. Velvety purple-maroon, long broad petals with a tendency to curl at ends. $\$ 1.50$ each.

MRS. JOHN L. EMERSON. A favorite garden and exhibition Dahlia. 6" to 8" flowers all season. Light golden yellow overlaid carmine-red, irregular in form. $\$ 2.00$ each.

MRS. I. DE VER WARNER. Masses of gigantic, perfect flowers under all conditions. Pleasing mauve-pink. Very long stiff stems. One of the best. $75 \mathrm{cts}$. each.

PAUL MICHAEL OR CALIFORNIA GOLD. One of the largest in existence, $6 "$ to $9^{\prime \prime}$ flowers are continually produced, a rich pure gold in color. $\$ 1.00$ each.

RADIO. A giant among giants, enormous flowers from six to ten inches in diameter, long stems, stiff as cane. A deep American Beauty red, with yellow blends and tips of gold. One of the outstanding new creations. Blooms freely. $\$ 2.00$ each.

SPECIAL OFFER: One each of the above FIVE EXCEPTIONAL, DAHLIAS (five distinct colors) for $\$ 6.60$ postpaid. (Value $\$ 7.25$.)

See exceptional Group offer of these two collections at bottom of page 60 


\section{Collins Twelve Enormous Dahlias}

AMUN RA. Wonderfully distinct in color and formation. A strong stemmed giant, but not coarse. Outer petals are copper and orange, shading to gold and amber, deepening in the center to dark reddish brown, like a gorgeous sunset. $\$ 1.00$ each.

BONNIE BRAE. A giant that produces flowers with exceptional freedom throughout the season. An exquisite blend of cream and yellow, effectively overlaid rose-pink. One of the best Decoratives, sure to please where large flowers are desired. $75 \mathrm{cts}$. each.

$\star$ THE BASHFUL GIANT. Deep, massive Decorative, growing from 6 " to $10^{\prime \prime}$ in diameter. Fine for exhibition. Apricot with buff and gold tints. $75 \mathrm{cts}$. each.

DR. TEVIS. Salmon-buff suffused old rose. Long stiff stems. One of the outstanding large Decoratives. $75 \mathrm{cts}$. each, 3 for $\$ 2.00$.

$\star$ GEORGE WALTERS. One of the largest Hybrid Cactus Dahlias. Perfectly formed flowers on long, stiff stems, well above foliage. Salmon-pink, blending to old gold. Fine for all purposes. $\$ 1.00$ each, 3 for $\$ 2.50$.

GLORY OF NEW HAVEN. Silvery-lilac, best of the orchids. Sturdy plants freely produce giant flowers on long, stiff stems. $\$ 1.00$ each, 6 for $\$ 5.00$.

$\star$ KALIF. Largest Scarlet $\mathrm{Hy}_{\mathrm{y}}$ brid Cactus. Unsurpassed for exhibition and garden. A rich, glowing scarlet. 75 cts. each, 3 for $\$ 2.00$.

$\star$ MILLIONAIRE. Flowers 6" to $12^{\prime \prime}$ in diameter. Lavender-pink, shading to white at the center. Dwarf grower. 75 cts. each, 3 for $\$ 2.00$.

MRS. CARL SALBACH. Gigantic flowers, often 6" to $9^{\prime \prime}$ in diameter, on stems $18^{\prime \prime}$ to 24 " long. Lavender-pink. $75 \mathrm{cts}$. each.

SNOWDRIFT. Largest of the pure white Decorative Dahlias. Dwarf grower.

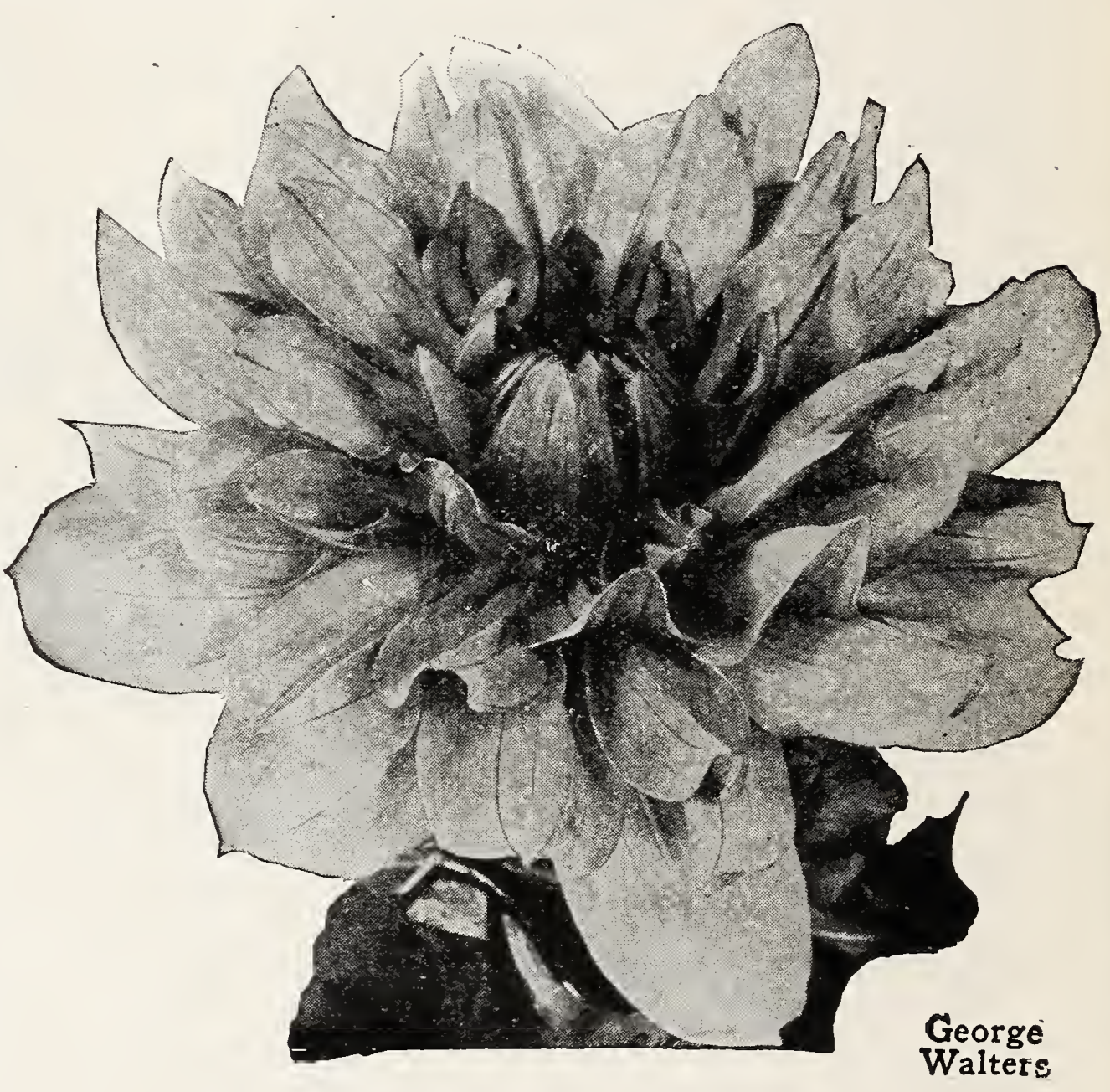
$\$ 1.00$ each.

THE EMPEROR. An exceptional variety of enormous size, beautiful deep color, perfectly formed flowers on extra long stems. A rich deep purple-maroon, which will not fade or spot. Long, flat, true Decorative type petals. \$1.00 each.

WILLIAM H. SLOCOMBE. The largest and best pale yellow Decorative Dahlia. Primrose yellow flowers are $6 "$ to $8^{\prime \prime}$ in diameter under ordinary conditions, and can be forced larger. Highly recommended for exhibition and garden. \$1.00 each.

SPECIAL OFFER: One each of the above 12 ENORMOUS DAHLIAS (12 distinct colors) for $\$ 9.85$ postpaid. (Regular value $\$ 10.50$.) Every Dahlia will produce $5^{\prime \prime}$ to $8^{\prime \prime}$ flowers ordinarily, and several can be forced to $10^{\prime \prime}$ and $12^{\prime \prime}$, with liquid manure.

^"Millionaire" offer -4 Enormous Dahlias, marked $(\star)$-all beauties-for $\$ 2.95$ postpaid.

\section{SPECIAL GROUP OFFER (covering pages 58-60)}

One bulb of each of these twelve outstanding Enormous Dahlias (page 60) together with one each of Collins' Phenomenal New Dahlias and Exceptional Dahlias (pages 58 and 59) (including President Hoover and Arthur J. Collins) the very best of the introductions for 1928 and $1929-(23$ bulbs in all $)$ for $\$ 26.25$ postpaid. Individual prices total $\$ 31.75$. 


\section{Collins Variety Collection}

Each has a different form and shape as well as a different color, no two alike.

CALIFORNIA ENCHANTRESS. A

Hybrid Cactus as near to ideal as has been developed; very large flowers, long stiff stems. blooms abundantly. Rose-pink blending to orchid pink, shading white at center. Fine for cutting. \$1.00 each.

MRS. BOWEN TUFTS. Semidouble rosy-purple flowers of large size, very abundant bloomer. 35 cts. each; 3 for $\$ 1.00$.

KING OF THE AUTUMN. Continuous beautiful fluffy golden bronze semi-double flowers on sturdy plants. 35 cts. ea., 3 for $\$ 1.00$.

MAURICE RIVOIRE. In addition to a row of large singleflowered maroon petals, a collar of shorter white petals surrounds the golden-yellow pollen center, very unusual. 35 cts. each; 3 for $\$ 1.00$.

MRS. C. D. ANDERSON. A large Hybrid Show of deep purplish crimson, so held by its stems that it is easily conspicuous. Abundant bloomer, highly recommended. 50 cts. each; 5 for $\$ 2.00$.

PRIDE OF CALIFORNIA. A gigantic Decorative Dahlia of rich crimson-red. Appropriately named, the pride of everyone who grows it, because of its enormous size, tremendous stems and robust growth. $50 \mathrm{cts}$. each; 5 for $\$ 2.00$.

SPECIAL OFFER: One each of the above VARIETY COLLECTION (six distinct colors and shapes) for $\$ 2.95$ postpaid.

\section{Collins Dahlia "Novelties"}

ACHIEVEMENT. A rare novelty dahlia with a single row of long irregular deep maroon petals, like the singla dahlias, but with an additional group of smaller pure white petals within each of the larger petals. The smaller petals are about a quarter of the length of the longer petals, a very attractive and distinct novelty. 50 cts. each.

AMY PEABODY. Large, loosely formed irregular petals of deep purplish-garnet with tips of white. Produces solid purple flowers, others heavily tipped white, while others may be slightly splashed with white. Although usually all flowers are different, occasionally one plant will produce solid purple flowers. $\$ 1.00$ each.

MILDRED ALGER. Large flowers of most unusual color combination; a pale buff to bronze very thickly splashed and striped with deep blacking-maroon. A continuous and abundant bloomer. One of the most desired of two-color dahlias. $\$ 1.00$ each.

MRS. ETHEL F. T. SMITH. Of very irregular formation, so different that most admirers think it is not a dahlia, because it somewhat resembles a star. Its petals are very long and pointed. Large flower, borne on long, stiff stems. Cream white flowers resembling a pond lily in color. 75 cts. each.

UNCERTAINTY. Ball-shaped flowers varying in color combinations from white through pink, pinkish-red to deep red-a variable and uncertain combination of colors, some marked, blotched and variegated in all ways. 35 cts. each, 3 for $\$ 1.00$.

THE EAGLE. Pale sulphur yellow flowers of novel shape, each petal being curled somewhat like a chrysanthemum. Splendid keeper when cut. Very effective. $\$ 1.00$ each. Free with Collins Color Plate Offer on Page 76.

SPECIAL OFFER: One each of the above Six Novelty Dahlias for \$4.25 postpaid. This group comprises a good variety of colors and practically all have two-color combinations. A very unusual and desirable group.

All Dahlias Postpaid at Prices Above 


\section{Eight Different Colored Dahlias for $\$ 1.65$}

A. D. LIVONI. Perfect ball-shaped exceptional shell-pink. Abundant bloomer, excellent for cutting. $25 \mathrm{cts}$. each.

DARLENE. See description, Special Dahlia Offer, page 76. 25 cts. each.

FRANK A. WALKER. Early bloomer, always a favorite. A very beautiful shade of lavender pink. $25 \mathrm{cts}$. each.

LITTLE JENNIE. A miniature primrose-yellow Pompon of great beauty. Fine for button-hole bouquets and for cutting. Free-flowering. 25 cts. each; 5 for $\$ 1.00$.

MARLEY. Deep golden yellow, with a frill of smaller paler yellow petals around the yellow pollen center, which makes it known as a Collarette Dahlia. Desired by those who admire Single Dahlias. Exceptionally free-flowering. 25 cts. each; 5 for $\$ 1.00$.

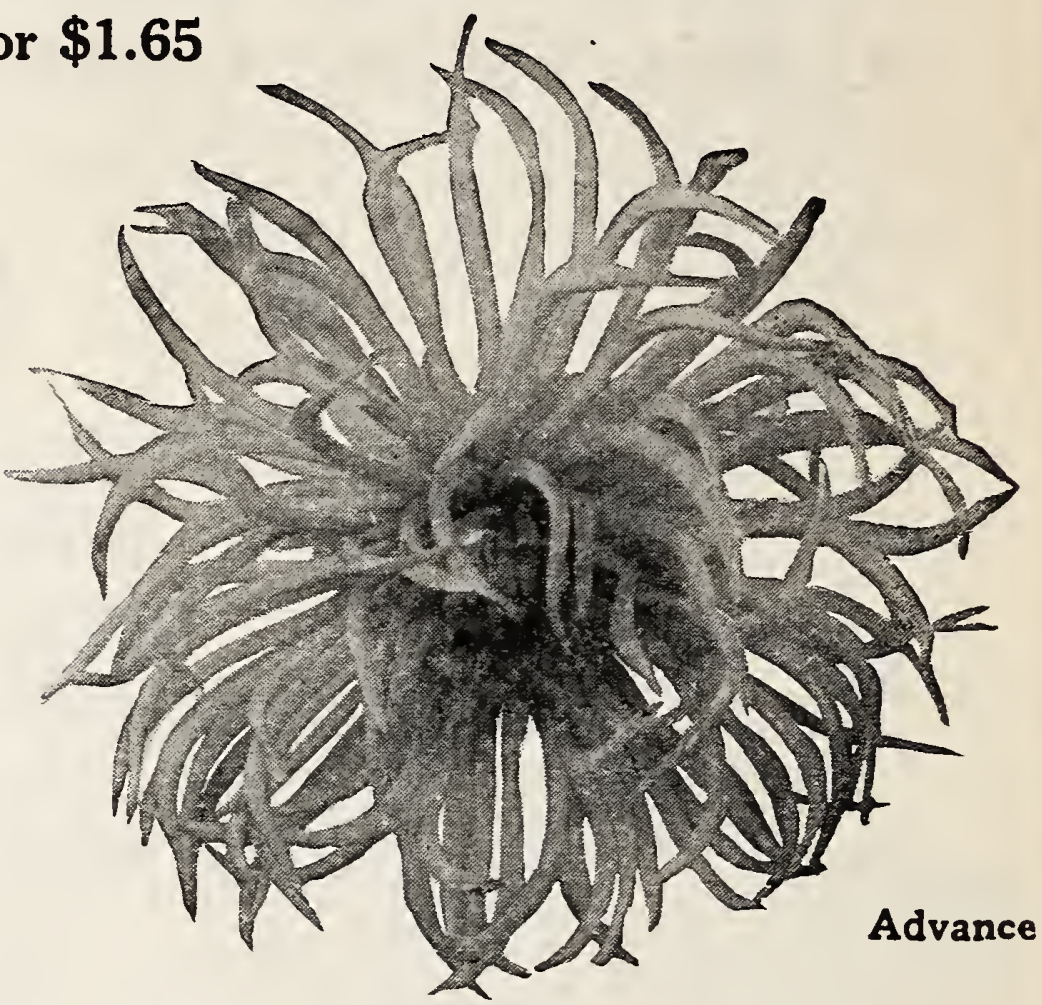

PRISCILLA AGNEW. Pure white, semi-double flowers. 25 cts. each.

SOUV. DE GUSTAVE DOAZON. Produces beautiful orange-red flowers, 5" to 10" in diameter. Sturdy grower. $35 \mathrm{cts}$. each; 3 for $\$ 1.00$.

SPECIAL OFFER: One each of above eight for $\$ 1.65$ postpaid. (Value \$1.85.)

\section{Cactus Dahlias}

\section{Distinctly different-always in demand}

ADVAIJCE. Bright fire-scarlet, with a slight blending of yellow at the center. An English Cactus Dahlia, long tightly quilled and twisted petals. $50 \mathrm{cts}$. each.

COUNTESS OF LONSDALE. One of the most abundant flowering Dahlias grown, a beautiful salmon-red Cactus. 50 cts. each.

EFFECTIVE. Bright primrose shaded amber; continuous and very abundant bloomer, one of the best Cactus Dahlias grown. $50 \mathrm{cts}$. each.

LIBELLE. A rosy-purple Chrysanthemum-like Cactus. Good bloomer, long, stiff stem; one we can recommend. 25 cts. each.

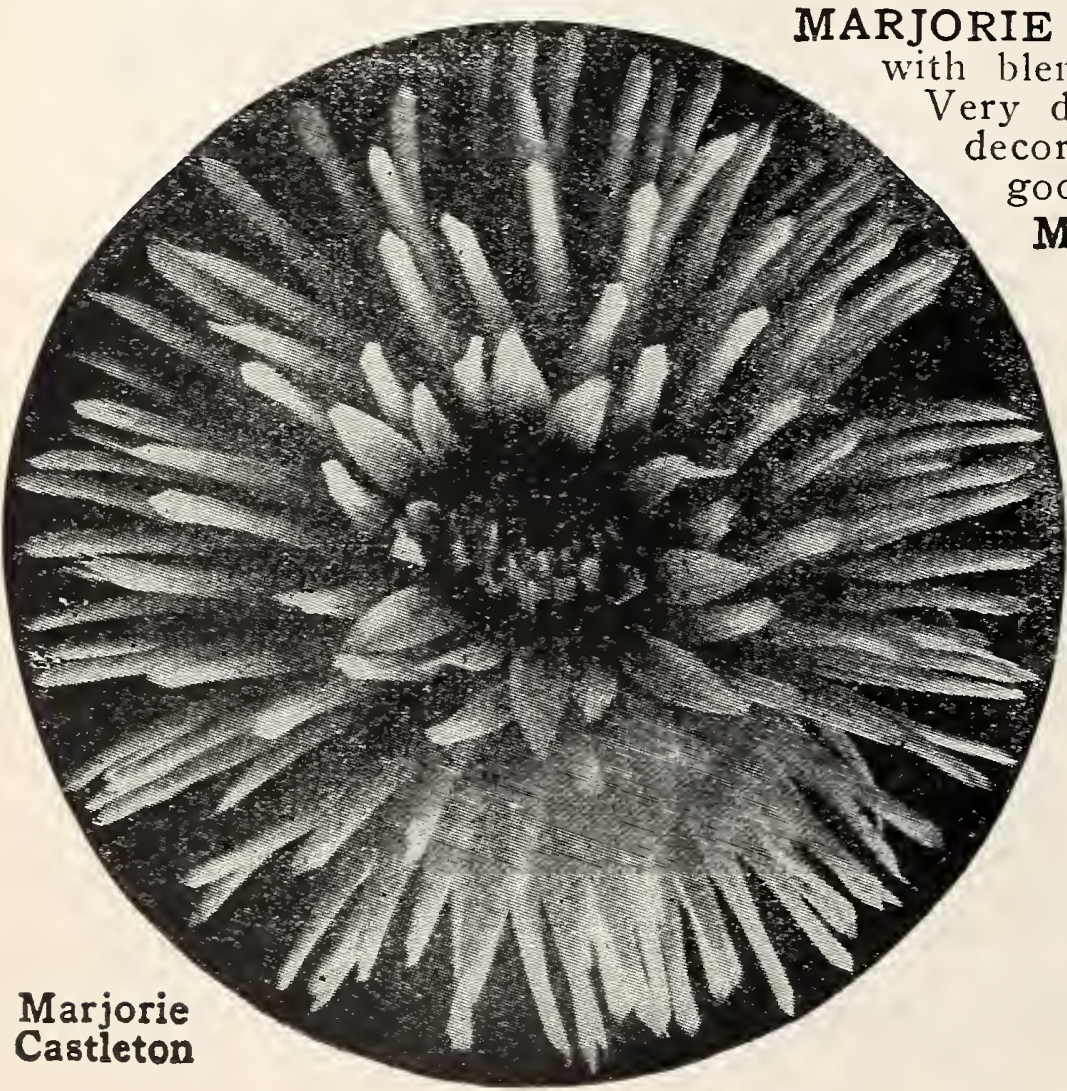

ASTLETON. Very early pink Cactus, Very dainty, making ideal bouquets for table ecoration. Continuous and abundant bloomer, good stems. $35 \mathrm{cts}$. each; 3 for $\$ 1.00$.

MRS. FERDINAND JEFFRIES. Abundant flowering wine-red Cactus Dahlia with tall, vigorous plants, blooms continuously through season. $75 \mathrm{cts}$. each.

SPECIAL OFFER: 1 each of the above six Dahlias for $\$ 2.55$ postpaid. A.complete variety of color among this popular type.

\section{RAINBOW MIXTURE}

A choice assortment of all colors, including purple, scarlet, salmon, pink, crimson, white, yellow, apricot yellow, and almost black; from ballshaped double Dahlias, through fluffy Peony-flowered types, to single flowered and the much-desired Cactus.

6 roots, $\$ 1.00$ postpaid; 10 roots. $\$ 1.50$ postpaid. 


\section{Collins Asparagus Roots Asparagus is good}

traised and a bed once established is good for 1 . ready for market in April and May, the income derived from it is especially appreciated at that time of the year. Collins Asparagus roots are grown on new land and we give them plenty of manure, which makes the roots healthy and vigorous, and able to produce for many years.

Asparagus does well on all good garden soils, but earliest crops come in light soil. Plant in spring in a trench of earth 8 to 10 inches deep, covering with 2 inches of earth, filling in trenches gradually as plants grow. Set 18 to 20 inches apart in rows; rows 4 to $4 \frac{1}{2}$ feet apart-6,220 plants to the acre.

\section{Pedigreed Mary Washington Asparagus}

The United States Department of Agriculture carried out a most painstaking and careful plant-breeding program which was designated primarily to eliminate asparagus rust, and as a result the strain or variety known as "Washington Asparagus" was originated and introduced. This new strain is so much better than any other asparagus, that it seems to be in a class by itself. The Bureau of Plant Industry circular says, "The shoots are very large on the average, very early and prolific. The high-branching habit of this strain makes it possible to cut unbranched shoots with good tight buds as much as two feet long. This strain suffers no appreciable loss under severe rust conditions."

We guarantee our roots to be from the true Mary Washington seed-beware of imitations-and our strain has been selected from seed fields composed of the plants that produce large straight shoots, dark green in color with a heavy purple over-tone, the tips are tight and firm and do not open or begin to branch until well out of the ground, which makes this strain especially satisfactory for every use. As a standard variety for fancy asparagus for the home garden as well as the market, it stands above all other varieties in size, vigor, tenderness, quality and rust-resistance. This new strain of asparagus is an innovation in asparagus growing and without a doubt will supplant all of the other kinds in the very near future, as soon as enough stock can be produced to supply all of the demand. We have only a limited supply of roots, but expect to be able to take care of nearly all of our orders. "We are using a great many thousand roots this spring for our own new fields, which will give us extensive plants from which to cut Asparagus for the city markets. Order early.

\section{Collins Offer Pedigreed Mary Washing- ton Asparagus Extra Selected Roots \\ 100 Fat, thrifty Roots, 3-yr..size, $\$ 2.50$ Postpaid 100 Fat, thrifty Roots, 2-yr. size, 2.00 Postpaid 100 Fat, thrifty Roots, 1-yr. size, 1.75 Postpaid Prices on larger quantities on request}

\section{Utilize Your Spare Garden Space}

100 Roots of Asparagus on a plot of ground 15 feet by 15 feet ( 10 rows $11 / 2$ feet apart), or 9 feet by 25 feet (six rows, $11 / 2$ feet apart).

Every garden has at least this small amount of spare space that ought to be growing tender, juicy Asparagus. A bed like this supplies the averagesized family for 20 years or more, almost without care. "The kind you raise beats the kind you buy." Cut it fresh just before cooking.

\section{OTHER VARIETIES OF ASPARAGUS}

GIANT. Early. Disease resistant, succeeding well in all climates. See prices below.

PALMETTO. Very early. Excellent quality. Hardy and very prolific. See prices below.

\begin{tabular}{llcc|ccc} 
& \multicolumn{4}{c|}{ Postpaid } & \multicolumn{3}{c}{ Express } \\
1 & yr. $\ldots \ldots \ldots$ & $\mathbf{5 0}$ & $\mathbf{1 0 0}$ & $\mathbf{2 5 0}$ & $\mathbf{5 0 0}$ & 1000 \\
2 & yr. $\ldots \ldots \ldots$ & .85 & $\$ 1.25$ & $\$ 2.75$ & $\$ 5.00$ & $\$ 8.00$ \\
1.00 & 1.60 & 3.25 & 6.00 & 10.00
\end{tabular}

Yield $\$ 300$ per Acre-Good for 15 to 20 Years

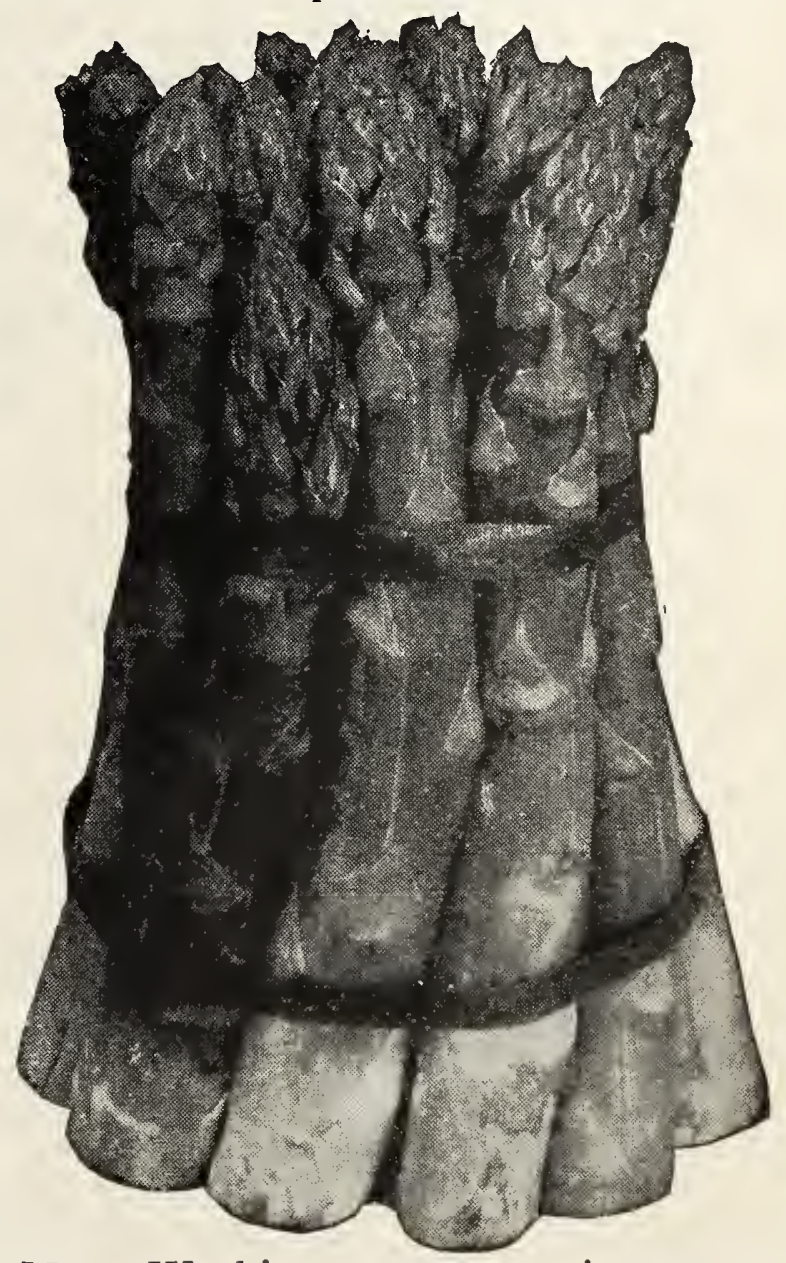

Mary Washington-rust resistant 


\section{Collins Raspberries}

The Raspberry is hardy, requiring little care, and is little affected by drought. Any soil capable of raising vegetables will raise good Raspberries.

CUTHBERT. Red. Very productive. Large, conical, rich, crimson berries. Delicious fruit. As a market berry and a shipper has no superior. Medium to late. 85 cts. for $10 ; \$ 6.50$ for 100 . Heavy, transplated $2-y r$. plants, $\$ 1.60$ for $10 ; \$ 14$ per 100 .

ST. REGIS. Red. Everbearing. The only variety that produces the same year it is planted and two crops a year thereafter. Bears continuously from about the middle of August until frost. The berries are large, beautiful, and attractive. $75 \mathrm{cts}$. for 10 ; $\$ 5.50$ per 100 . Heavy, transplanted $2-y r$. plants, $\$ 1.50$ for $10 ; \$ 13.50$ per 100 .

Quantity prices on application.

SPECIAL OFFER: Six each of Cuthbert and St. Regis Everbearing, twelve strong plants for $80 \mathrm{cts}$; transplanted plants, $\$ 1.75$ postpaid.

\section{Collins Blackberries-A PROFI сROP}

Fertile soil makes great crops. Our plants, from root cuttings, are very desirable.

ELDORADO. The plant is very hardy and has not been known to winter-kill in any section of the country. Free from rust. $\$ 1.10$ for $10 ; \$ 8.50$ per 100 .

WARD. Vigorous grower of beautiful large berries. Fruit black throughout, almost wholly without a core, firm, yet tender and of best quality. More largely grown than any other variety. Plant is rust-resistant. Mid-season. $\$ 1$ for $10 ; \$ 8$ per 100 . Quantity prices on application

SPECIAL OFFER: Three each of Eldorado and Ward, six strong plants in all, for 55 cts. postpaid.

\section{Collins Select Strawberry Plants}

We strive to produce the best plants possible; manuring heavily and plowing deeply before setting out young plants in the spring. Beds are hoed frequently, producing sturdy, healthy, well-rooted young plants by fall, which will give you results.

NOTE: Upon receipt of your order your Strawberry Plants are dug, packed in damp moss and mailed immediately. When they arrive plant them promptly, or keep in a cool place. Never allow the roots to become dry, and you should not lose a plant.

\section{VERY EARLY VARIETIES}

PREMIER (Howard No. 17). See description under Special Offer on facing page.

EARLY JERSEY GIANT. Yields very large berries very early in the season. Ripen all over at once; flavor rich and mild, berries very showy.

\section{MID-SEASON VARIETY}

BIG JOE. See description under Special Offer on facing page.

\section{LATE VARIETIES}

WM. BELT. Berries of excellent flavor, quite firm and fancy. Plants very productive, rugged and stand drought well, satisfactory for either garden or market.

LUPTON. See description under Special Offer. Price, 25 plants $\$ 1 ; 50$ plants $\$ 1.50$; 100 plants $\$ 2.25 ; 250$ plants $\$ 3.10 ; 500$ plants $\$ 4.75$.

GANDY. Berries large and firm, highly colored and uniform. Plant strong grower; produces big crops.

Prices on Early, Mid-season and Late plants (except Lupton), all of one kind, 25 plants $85 \mathrm{c} ; 50$ plants $\$ 1.35 ; 100$ plants $\$ 2.10 ; 250$ plants $\$ 2.90 ; 500$ plants $\$ 4.25$, including postage and special packing up to and including 4th postal zone from Moorestown. Prices of larger quantities on request.

\section{COLLINS EVERBEARING STRAWBERRIES}

PROGRESSIVE. See description under Special Offer. 25 plants $\$ 1.50 ; 50$ plants $\$ 2.25$; 100 plants $\$ 3 ; 250$ plants $\$ 5$, postpaid. Prices for larger quantities on application.

LUCKY STRIKE. Of exceptional quality and rich flavor. In addition to a good spring crop it produces heavily during July and August, and October and November. Makes a large quantity of young plants. 25 plants $\$ 2.35: 50$ plants $\$ 3.85 ; 100$ plants $\$ 6.50 ; 250$ plants $\$ 12.50$, postpaid. Prices for larger quantities on request.

(See opposite page for remarkable postpaid offer) 


\section{Collins Good Grapes}

Grapes can be planted anywhere and will thrive with practically no attention. They will trail over an old back fence or the arbor. The side of your house will be equally attractive to them. Prune them back in the fall so they will keep young and thrifty.

\section{All vines, strong 2-yrs. old, bear this or next year. Postpaid for prices named. Special prices in lots of 1000 or more.}

CA-CO. Red. This Grape is a cross between Catawba and Concord scientifically made, and possesses the merits of both varieties, with the defects of neither. Its good qualities are: High quality, surpassing in tenderness of pulp, luscious flavor and aroma of Catawba; rich, sparkling wine-red, with abundant bloom; bunch large and compact; berry medium to large and nearly round; season early, a little in advance of Concord; skin thin and tough; berry adheres firmly to bunch; a superior shipper and keeper; exempt from rot. The vine is very vigorous and a heavy, annual yielder. 85 cts. each; $\$ 7.50$ for $10, \$ 60$ per 100 .

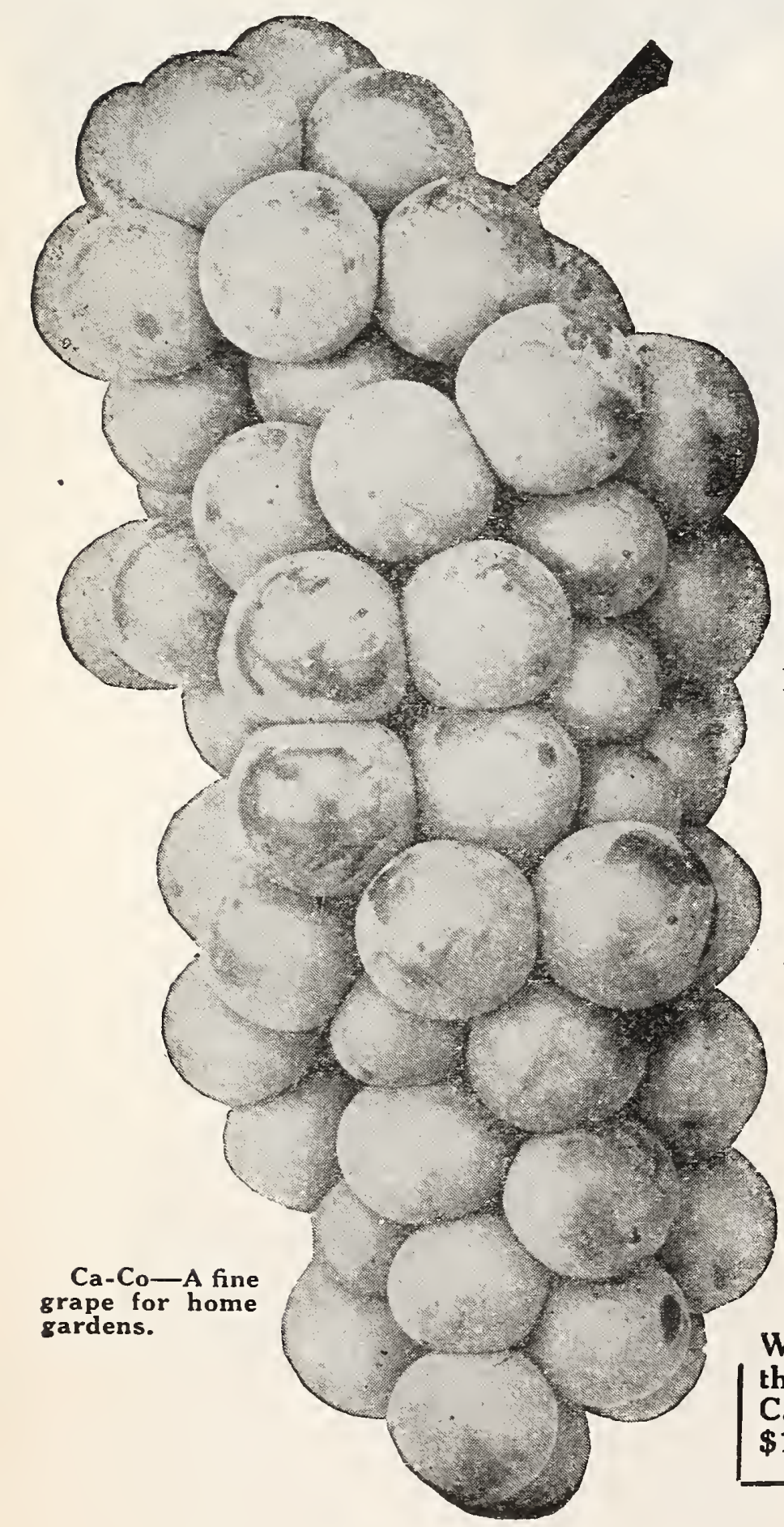

CATAWBA. Red. This is the standard red market Grape. The pulp is sweet and the quality excellent. The bunch is large, moderately compact and shouldered. The berries are of good size and have tough skin. It adapts itself to almost any locality or climate, and is a good shipper and a long keeper. It is a good grower and is very hardy and productive. Late. 35 cts. each; $\$ 2.75$ for $10 ; \$ 20$ per 100 .

CONCORD. Black. The most popular market and garden Grape in America. Bunches large, compact and shouldered. Berry large, juicy and sweet, and excellent for grape juice. The vine is quite insect and disease resistant. It ripens early to mid-season, maturing its fruit before frost. Our plants have a splendid rootsystem. 30 cts. each; $\$ 2.25$ for $10 ; \$ 18$ per 100 .

DELAWARE. Red. Is attractive, keeps well on the vine and in the box; is free from the black rot, all of which goes to make it an excellent market Grape. Bunch small and compact, berries small, but juicy and sweet, with thin but tough skin. 50 cts. each; $\$ 4.00$ for $10 ; \$ 30$ per 100.

HUBBARD. Sweet, delicious, with fine flavor Seeds few and small, pulp tender, skin thin and firm. Berries and bunch large and uniform. Ripens ten days ahead of Concord. Truly a wonderful grape. Said by some to surpass the Concord and Niagara. 85 cts. each; $\$ 7.50$ for $10 ; \$ 60$ per 100 .

\section{COLLINS SPECIAL \\ GRAPE VINE OFFER}

We offer you six vines in all. Two plants each of the three most popular grapes for home-gardensCatawba, Concord and Niagara 2-yr. vines for $\$ 1.50$ postpaid. (A $\$ 2.10$ value.) 
MOORE'S EARLY. Black. Ripens two or three weeks earlier than the Concord. The berries are larger but the bunch is somewhat smaller than that of the Concord. The skin is thin, the flesh is sweet, and the quality is good. $50 \mathrm{cts}$. each; $\$ 4$ for $10 ; \$ 30$ per 100 .

NIAGARA. White. The bunch is large and handsome. It is compact and sometimes shouldered. The berries are large and very sweet. The skin is thin but tough, and the bunch makes a fine appearance. This is the standard white Grape and we think it will continue to be so for some time. The vine is vigorous and comparatively free from disease, though it responds well to care. 35 cts. each; $\$ 2.75$ for $10 ; \$ 20$ per 100 .

POCKLINGTON. Pale green. The bunches are large and compact, and the berries are very large, being covered with a beautiful white bloom. The quality is good and it ripens soon after the Concord. Very hardy and productive. The skin is thin and the flesh is sweet and juicy and a little foxy in flavor. $50 \mathrm{cts}$. each; $\$ 4$ for $10 ; \$ 30$ per 100 .

SALEM. Dark red. The bunch is large, compact, and shouldered. The berries are large and round, having a thick, firm-skin. The flesh is very sweet and tender. Earlier than the Concord. Hardy and vigorous. 50 cts. each; $\$ 4$ for $10 ; \$ 30$ per 100.

WORDEN. Black. A close rival to the famous Concord. The grape and the bunches are larger, the fruit is of better quality. The pulp is very tender. A very popular grape. Hardy and vigorous. 50 cts. each; $\$ 4$ for $10 ; \$ 30$ per 100 .

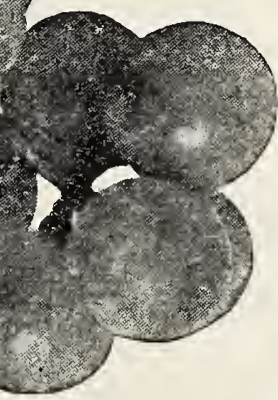

WYOMING RED. Light red. This ripens with the Delaware which it much resembles in appearance, though the bunch and the berries are larger. The berries are sweet and pulpy, and the vine is a good strong grower. 50 cts. each; $\$ 4$ for $10 ; \$ 30$ per 100 .

\section{Grow Better Grapes with Collins Strong 2-yr. Vines}

As a help we suggest "American Grape Growing and Wine Making." By George Husmann. Illustrated. Cloth bound, $\$ 2.00$, postpaid. An authoritative book covering the whole subject.

\section{COLLINS DOLLAR GRAPE VINE COLLECTION}

Five Splendid Concord Grape Vines 2 years old for $\$ 1$ fence you have neglected so long.) 


\section{Collins Cherries}

Cherries are one of the most profitable fruits under cultivation. They require the least attention of any fruit and are ideal for the home garden. Enormous profits are being realized from young orchards, for they come into bearing at an early age and yield abundantly.

BLACK TARTARIAN. Sweet. Fruit is purplish black, and is large and of sweet, jelly-like consistency. Tree makes a fine, erect growth; produces immense crops.

EARLY RICHMOND. Sour. Fruits soon after planted, and is an unusually heavy cropper. The most hardy of all varieties and is uninjured by the coldest winters. Fruit is medium size, round, and dark red. Flesh is tender, juicy, and subacid. Early.

GOVERNOR WOOD. Sweet. One of the best Cherries. Very large; light yellow marbled with red; juicy, rich, and delicious; tree healthy and a good bearer; fruit hangs well on the tree. Ripens the last of June.

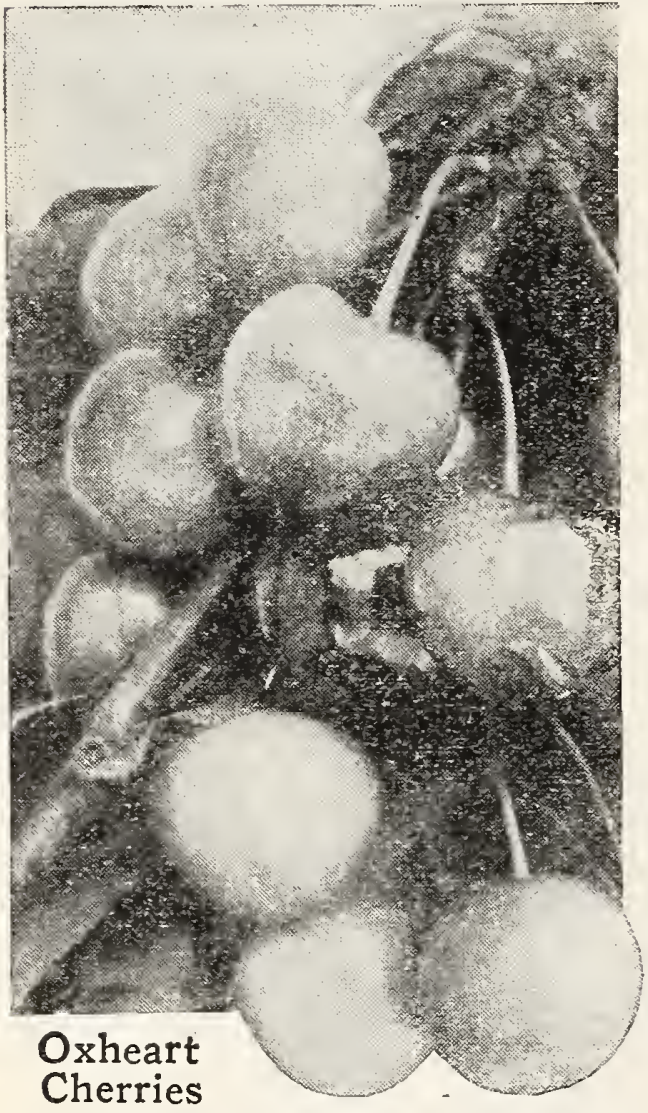

MONTMORENCY. Sour. Late. A beautiful, large red cherry, much larger and firmer than Early Richmond, and fully ten days later in ripening. The best for canning and preserving. It is THE sour Cherry, and the fruit is in great demand.

NAPOLEON. Sweet. Tree medium size and erect. Fruit borne usually in pairs, very large and oblong; light yellow, with red cheeks where the sun strikes them; fruit solid, and red at the stone. A fine bearer.

OXHEART. Sweet. Large; light with red cheek; solid, meaty, rich and excellent. Always in demand, bringing top prices.

WINDSOR. Sweet. The tree is vigorous and hardy, and bears early. The Cherries are heart-shaped, dark purple, and the flesh is quite firm, fine in texture, and rich in flavor. Ripens early. Fruit is large and will hang on the tree a long while without rotting.

Special Cherry Tree Offer.-One each of Montmorency, Windsor and Governor Wood, three Cherry trees in all, for $\$ 3.20$ f. o. b. Moorestown. All largest size trees. Excellent assortment. Regular value, $\$ 3.75$.

\begin{tabular}{|c|c|c|c|}
\hline $\begin{array}{l}\text { rices of Cherries: Each } \\
4 \text { to } 5 \mathrm{ft} \ldots \ldots \ldots \$ .90 \\
5 \text { to } 6 \mathrm{ft} \ldots \ldots \ldots 1.10\end{array}$ & $\begin{array}{c}10 \text { Trees } \\
\text { One Kind } \\
\$ 8.10 \\
9.90 \\
11.25\end{array}$ & $\begin{array}{c}50 \text { Trees } \\
\text { One Kind } \\
\$ 36.00 \\
44.00 \\
50.00\end{array}$ & ${ }_{\mathbf{R}}$ \\
\hline
\end{tabular}

Don't be misled into buying "cheap fruit trees." Collins Trees are not "Cheap Fruit Trees" that are poorly grown, shrivelled and starved, but are robust, healthy, full of life and vigor, quick to bear. The Collins family have always been among the largest orchardists, and you benefit by their experience.

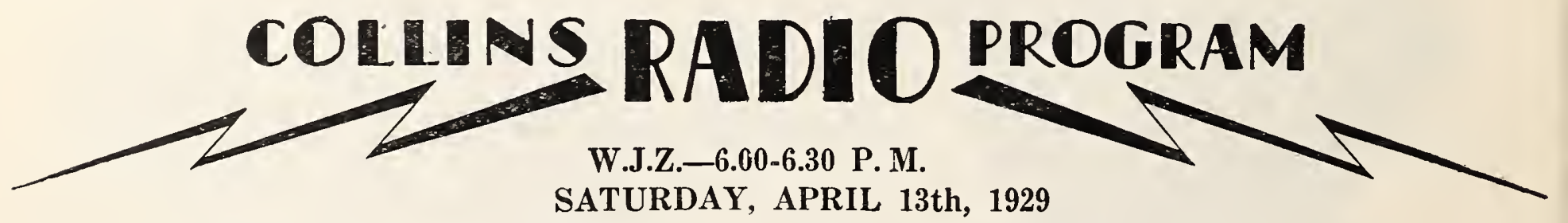

Mighty Like a Rose-Opening Theme

Minuet-Boccherini's

Little White Rose-(Vocal)

Roses of Picardy

Helpful Talk on Rose Culture
Rose in the Bud-(Vocal)

Kammenoi-Ostrow

June Brought the Roses-(Vocal)

The Swan

Mighty Like a Rose-Closing Theme

For Radio Program of following week, see page 74 


\section{Peaches That Pay Profits}

If you have only a small farm or a little garden space that will grow a tree, by all means plant Peach Trees. They soon pay for themselves. Our Peach Trees yield over half a bushel per tree the third year-they can do it because we grow them with good roots and free from disease-they're fine young thrifty stock. Have fresh peaches in your garden and sell the surplus. Most popular varieties are in CAPITAL letters.

Plant them $16 \times 18$ feet apart requiring 150 trees to the acre.

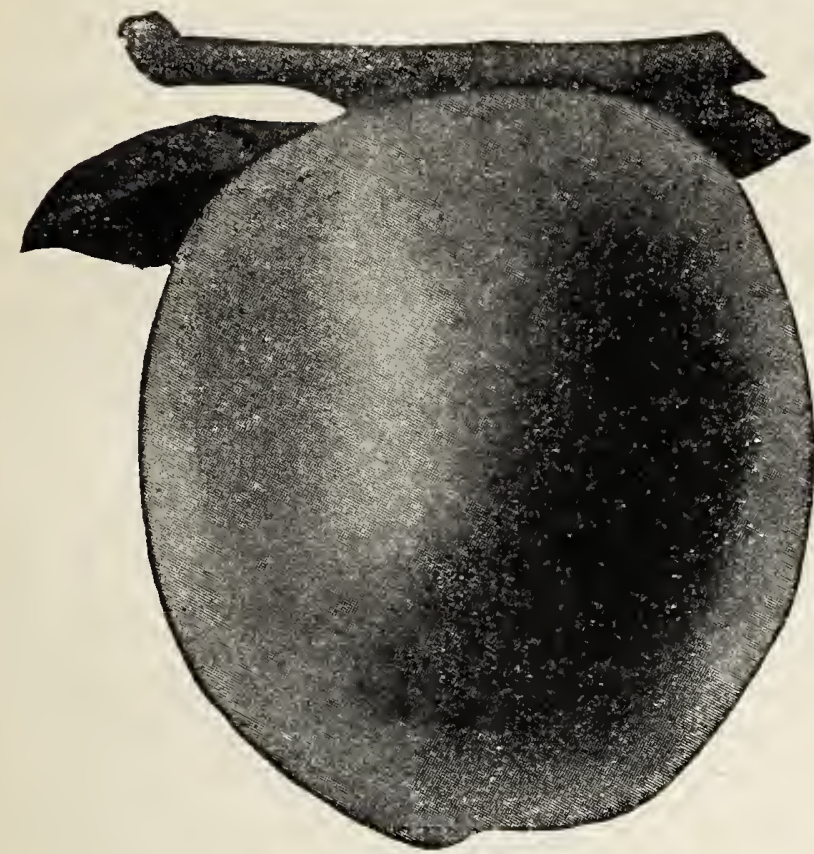

Belle of Georgia

ELBERTA. Free. Yellow. The leader of all Peaches and the greatest commercial variety on the market, over 50 per cent of the Peaches planted being Elberta. This will thrive where any Peach can be grown. A beautiful Peach of good quality; not only the best orchard variety; but also valuable for the garden. It is large, yellow, has a red cheek, and is good and juicy with a high flavor. A fine variety for canning. The Elberta is hardier in bud than many varieties and therefore a more uniform cropper. Early September.

Hale. Free. Yellow. Ripens just before Elberta; better in quality and usually larger. Yellow and deep red. Medium producer. Early September.

IRON MOUNTAIN. Free. White. Size enormous, egg-shaped; color pure white, with slight blush; good quality; good keeper; very regular bearer. October.

You cannot get good Peaches from cheap trees that have been starved. Buy Collins trees that are full of life.

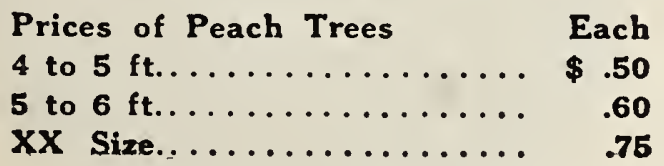

BELLE OF GEORGIA. Free. White. Very large. Skin white with red cheek. White, firm flesh of excellent flavor. Very prolific. July.

Crawford's Early. Free. Yellow. A fine big yellow Peach with red cheek; oblong; flavor excellent; healthy grower. First of September.

CRAWFORD'S LATE. Free. Yellow. The fruit is of large size, the skin yellow with red cheek; the flesh is yellow rich, and juicy. The tree is vigorous and is moderately productive. Last of September.
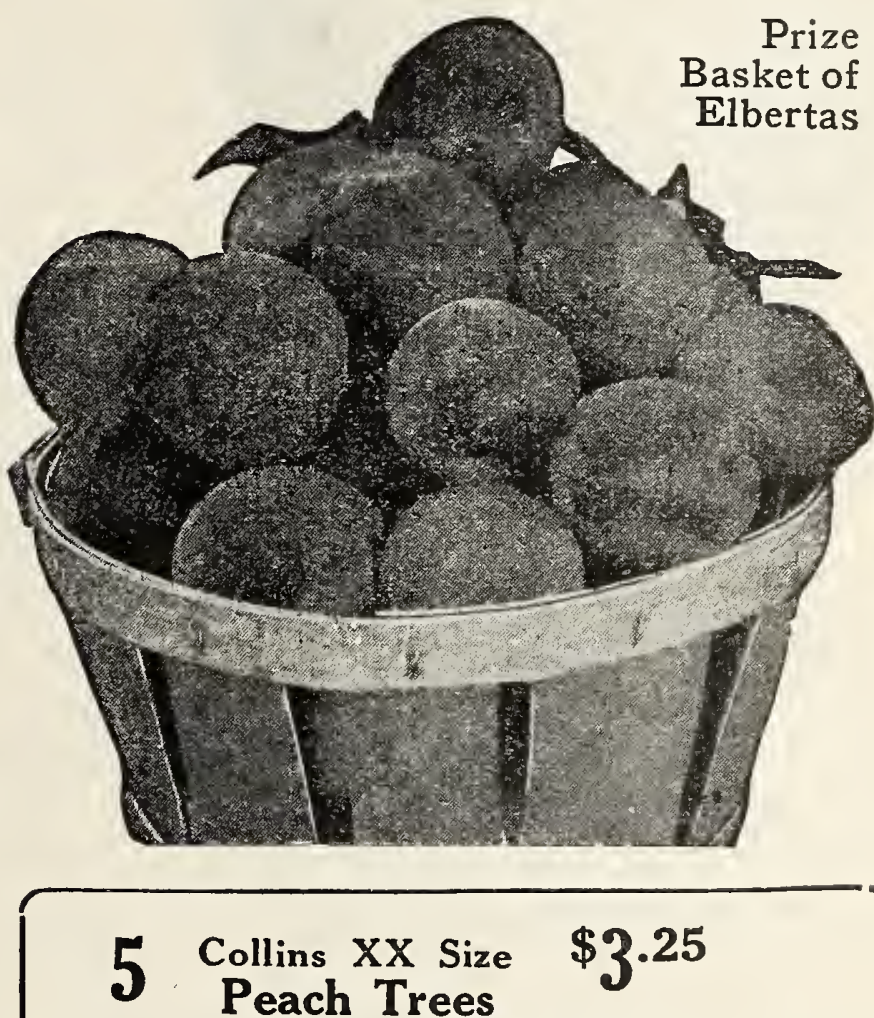

(Regular value \$3.75)

Finest succession of Peaches all summer and fall.

\section{Early Crawford Elberta}

Hale Belle of Georgia

Crawford's Late

In this exceptional collection you get sturdy, well-grown COLLINS trees, with plenty of roots, which quickly develop into bearing trees. A fine foundation for your fruit garden.
5 at the 10 rate Quantity Prices on

Application 


\section{Collins Quality Apple Trees}

On these two pages we offer you the leading varieties of standard Apple Trees. Collins trees are healthy, they have good roots and tops, and are clean and vigorous. Plant an APPLE TREE in your garden, a strong, sturdy tree, you will soon enjoy its fruit-so will your children and your children's children. That means fresh fruit to eat when you want it, and pies and sauces and jellies unending.

We are extensive fruit-growers ourselves having over 50,000 Apple Trees in our own orchards, and we shall be glad to offer you suggestions and help you where we can. We believe in our own trees-have planted them in our own orchards for over 60 years.

Plant $20 \times 20 \mathrm{ft}$, or 110 trees per acre. Popular Varieties in CAPITAL letters.

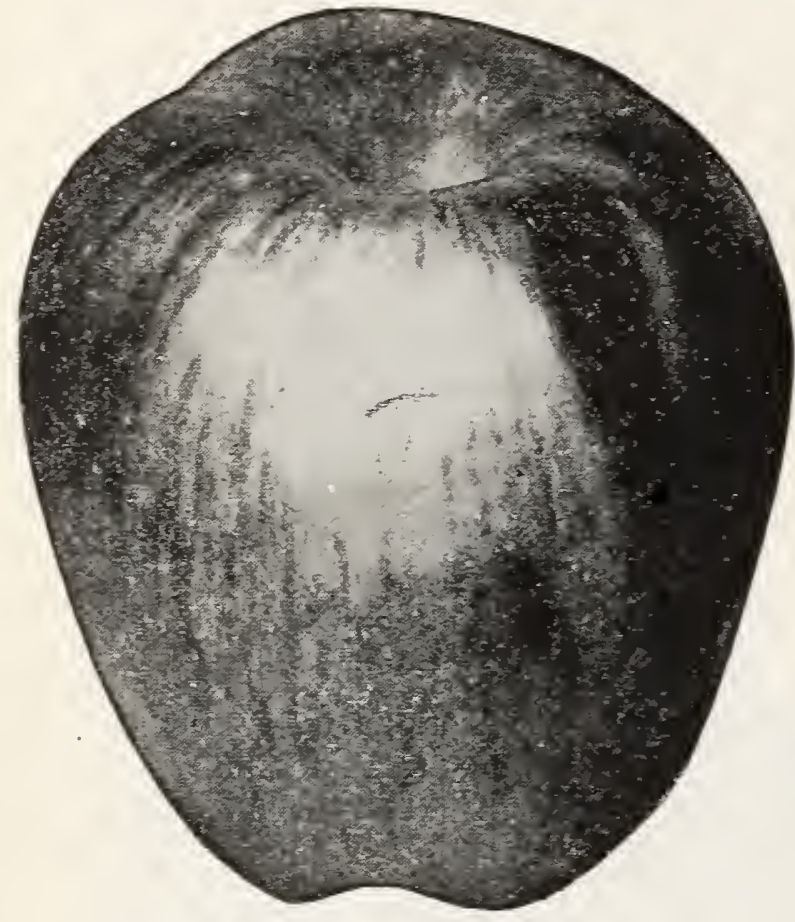

Delicious-all that the name implies

BALDWIN. Winter. Large; deep red, crisp, juicy, and rich flavored.

DELICIOUS. Autumn. Fruit large, nearly covered with brilliant dark red; flesh finegrained, crisp and melting; with delightful aroma; very highest quality; a splendid keeper and shipper; tree hardy. (See photo).

Early Harvest. Summer. Medium; pale yellow; tender and good. Good throughout the northern states and the northwest.

GRIMES GOLDEN. Fall and winter. A fine table and cooking Apple; yellow, rich and tender. When fully mellowed, it is one of the best eating Apples grown. Tree very productive. Apple large and of splendid flavor; a good keeper.

JONATHAN. Winter. A beautiful red Apple, highly flavored, tender, juicy, spicy, and rich; splendid for family use and highly profitable for market; tree long lived, productive and an early bearer. (See cut.)

McINTOSH. Early winter. A large attractive apple, nearly all red, tender, juicy and refreshing. Hardy, vigorous, and a good annual crop bearer. Has no superior as an early winter Apple.

STAYMAN'S WINESAP. Winter. In appearance and flavor one of the best Apples grown. Quite juicy, a fayorite for making cider. Of medium size, conical, and mostly covered with red and yellow markings. Flesh fine, crisp, and of fine flavor. Will keep well till the following April if kept in a cool place and not disturbed.

WEALTHY. Summer and fall. Large size when full grown. Abundant cropper through a long season. Fruit red with white streaks; quality good; full of juice; fine for sauce or pies. Hardy. Bears early and is a fine shipper.

\section{Excellent XX Size $\$ 4.25$}

(Regular Value \$5.00)

Fine succession of fruit at all seasons.

$$
\text { Early Harvest Wealthy }
$$

Grimes Golden Delicious

Stayman's Winesap

We send you real value. COLLINS thrifty, clean apple trees, well-rooted, quickly develop into bearing trees. Start your garden now-benefit for years to come.

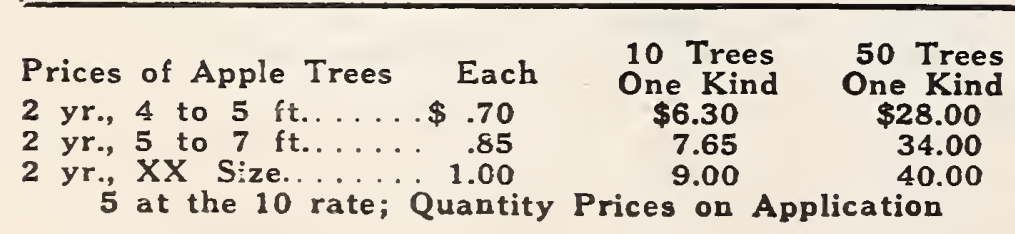

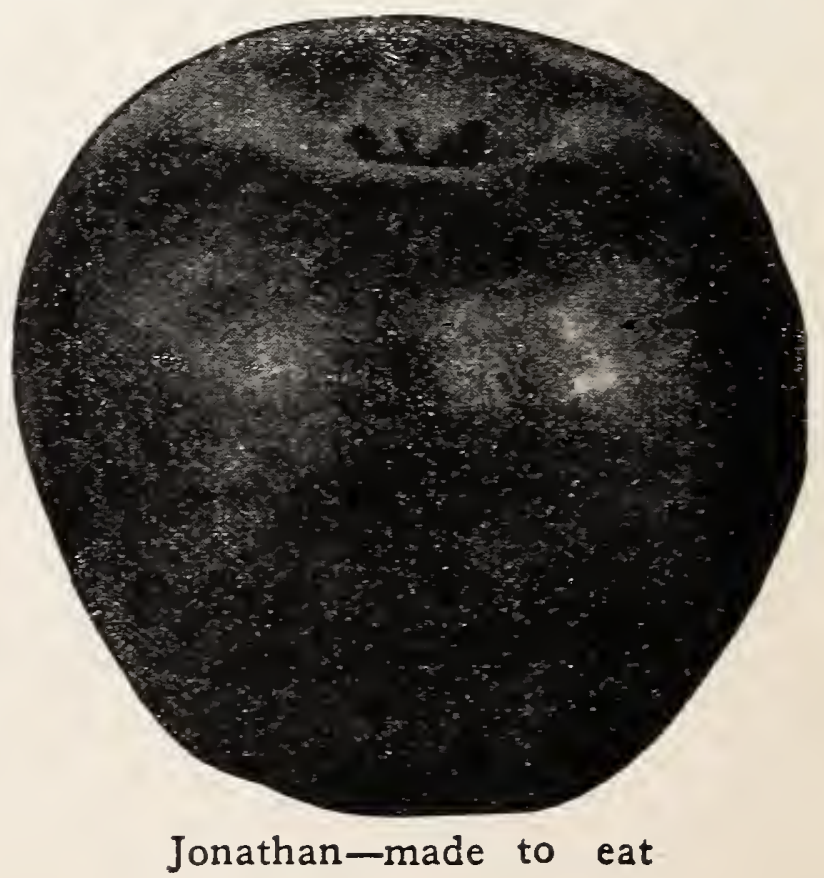




\section{Collins Dwarf Fruit Trees}

Apple and Pear Trees at half

size producing Full Size Fruit

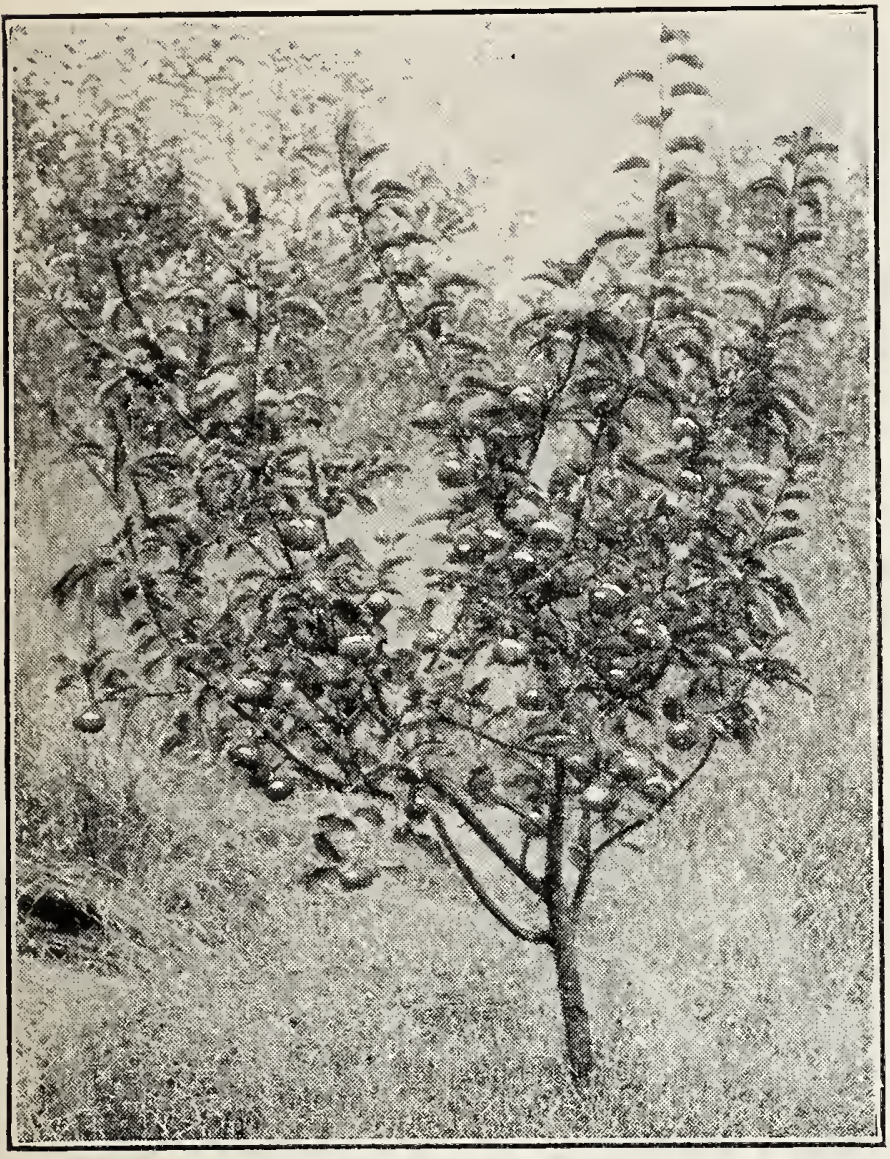

Dwarf Apple Tree

\section{PLUMS}

BURBANK. Orange-yellow, overlaid with red. (Japan.) Medium to rather large on thinned trees, roundish conical in form; flesh firm, meaty, yellow, rich, sugary. Exceedingly productive.

GERMAN PRUNE. Purple (European.) Fruit oval in shape, nearly 2 inches long. Good quality; hangs well on the tree; is firm and sweet. A splendid preserving sort and excellent for dessert. Tree vigorous and productive.
Prices
Each
4 to $5 \mathrm{ft} \ldots \ldots \ldots \ldots \ldots \ldots \ldots . .80$
5 to 7 ft.............. 1.00

10
$\$ 7.50$
9.25
11.25
25
$\$ 18.75$
22.50
XX Size $\ldots \ldots \ldots \ldots \ldots \ldots \ldots, 1.25$
9.25
11.25
$\mathbf{2 7 . 5 0}$

BARTLETT. Large, yellow, tinged with red, buttery and melting, with a rich flavor. Vigorous, excellent for garden or commercial planting. The best canning pear. Bears abundantly at about 3 years.

SECKEL. Late. Small, but fine for pickling and dessert. Very productive, yellow russet with delicious flavor, melting, juicy; a general favorite.

SHELDON. Fall. Large, round, yellow; fine grower. Productive.

Prices of

ear Trees 4.5 $\mathrm{ft}$. $5-6 \mathrm{ft}$.

XX Size Each

Each
$\$ .90$
1.10
1.35

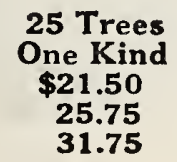

5 at 10 rate Quantity Prices on

DWARF APPLE TREES, always remain vigorous small Plant iner growing to a great height. apples:

Wealthy, Delicious, Early Harvest,

COLIINS DWARF PEARS. If you wish a Pear orchard and have only a rly, plant dwarfs These are Bartlett, Duchess, Clapp's Favorite \& Seckel

Price of all of above Dwarf Trees $\$ 1.00$ each; $\$ 10.00$ per doz.; $\$ 40.00$ for 50

\section{SPECIAL OFFERS}

F. O. B. Moorestown Five dwarf fruit trees for $\$ 4.50$ (no more than two of any one kind in your selection).

Two Plum Trees for $\$ 2.00$ (Regular price \$2.50.)

Largest size trees.

One each of Burbank and German Prune.

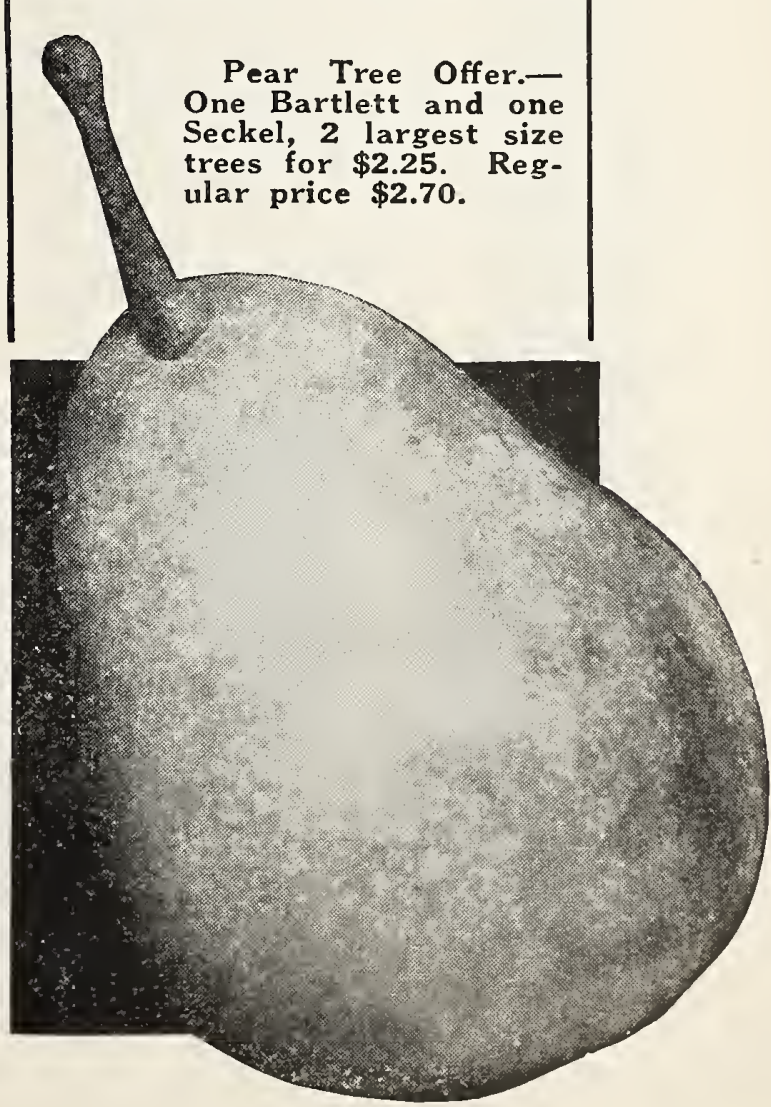




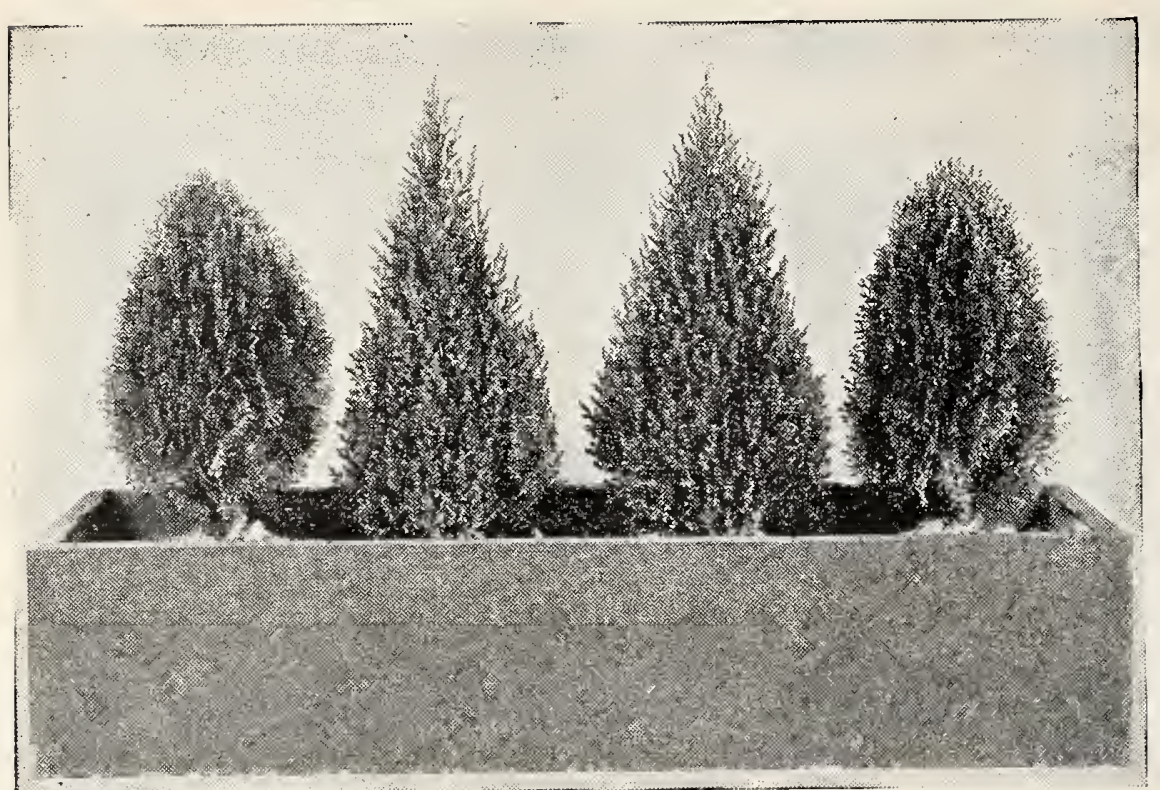

\section{Window Boxes}

There is no better way to add a "homey" touch to your windows than by one of these window box assortments. Sprightly dwarf evergreens add a cheery note both summer and winter.

Assortment No. 1 (at left) consists of 4 evergreen gems -two handsome Berkman's Arborvitae (12 to 15 inches high) and two cone-shaped Greek Junipers (15 to 18 inches high). See description of Evergreens pages $31 \& 33$

Price at nursery, $\$ 5.50 *$.

For express shipment, $\$ 5.90$.

Assortment No. 2 (at right) includes five handsome evergreens, three Berkman's Arborvitae (12 to 15 inch) and two carefully selected dwarf Boxwood (10 to 12 inch), as on page 29.

Price at nursery, $\$ 7.50 *$.

Packed for shipment, $\$ 7.90$ by express.

* Both assortments fit ideally in a porch box $1 \mathrm{ft}$. $\times 1 \mathrm{ft}$. $\times 3 \mathrm{ft}$. 6 in. Such a box, green painted, $\$ 2.00$ extra.

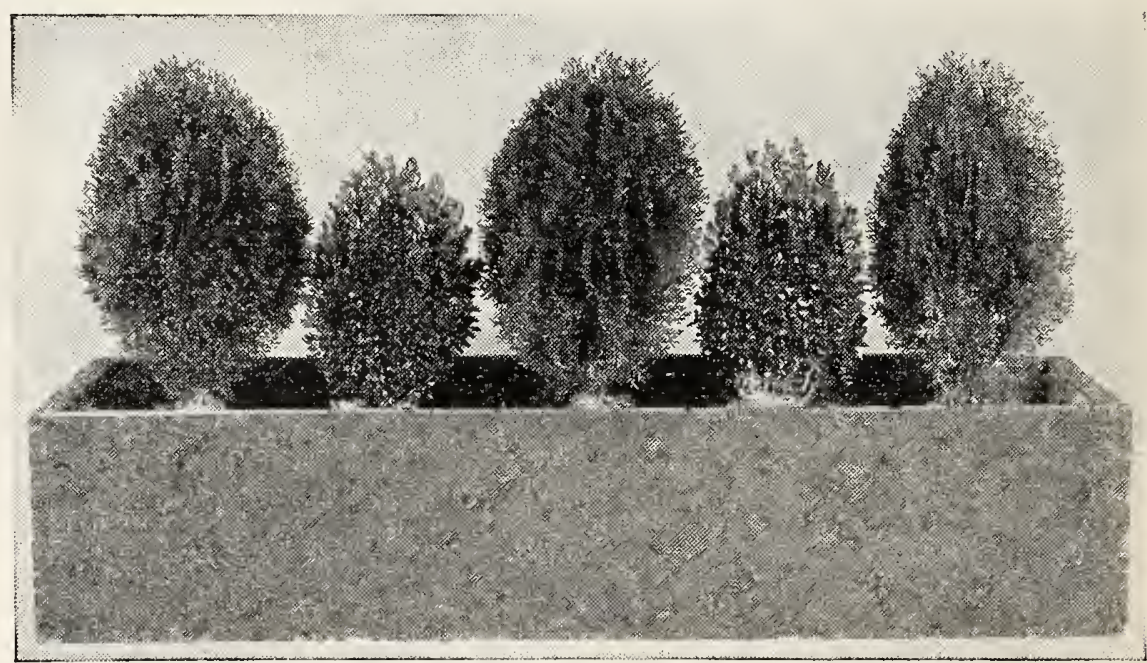

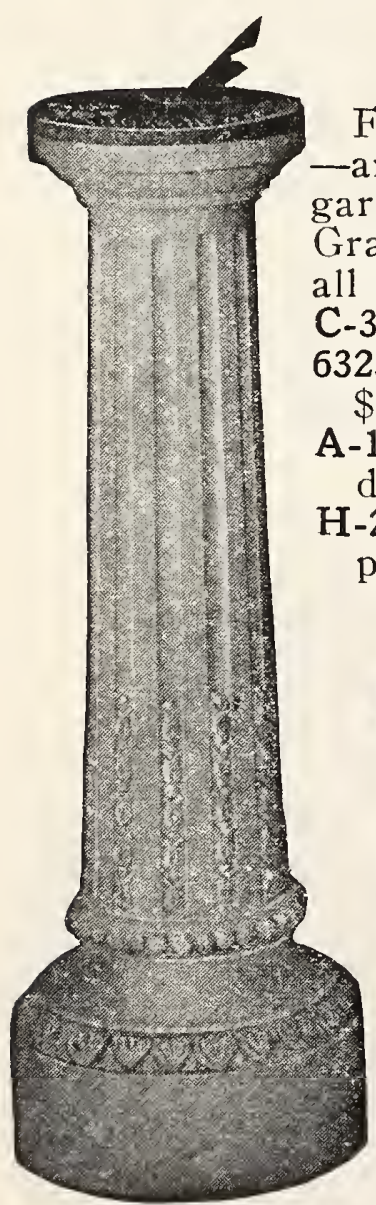

C-3

\section{Collins Garden Furniture}

Few joys are so keen as those of working to make a garden more beautiful -and one of the pieces offered here will add the touch of perfection. This garden ware is made by a special process, of crushed white Marble or Granite and Cement throughout, metal reinforced, guaranteed to withstand all climatic conditions and continue to hold its strength and color for years. C-3 Sun Dial, height 361/2", base 121/2", top $10^{\prime \prime}$, price $\$ 21.00$, f.o.b. factory. 6323-The Lark Bird Bath, height 32", base 103/4", diameter at top 23", price $\$ 14.00$ f.o.b. factory.

A-10 Garden Urn, figured, height 8", base 7", diameter at top $10^{\prime \prime}$, price $\$ 4.00$, f.o.b. factory. -24 Froggie Fountain, height 14", base 10", piped for fountain, price $\$ 7.50$, f.o.b. factory.

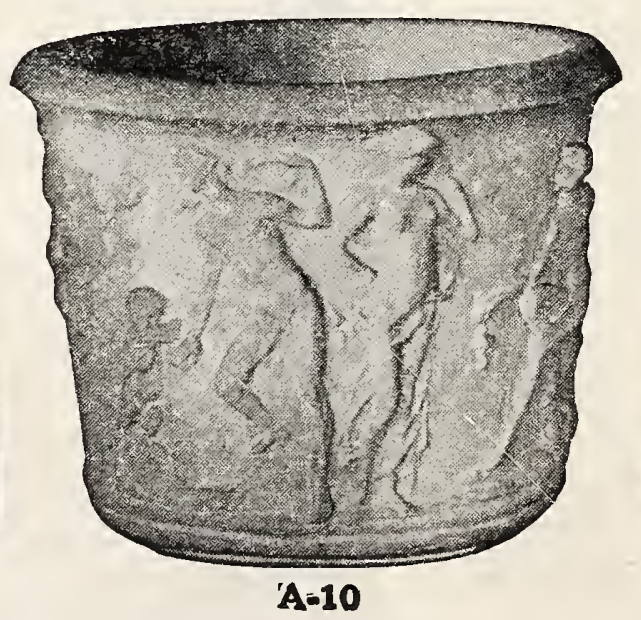

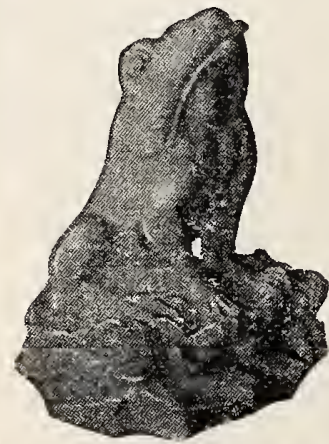

H-24

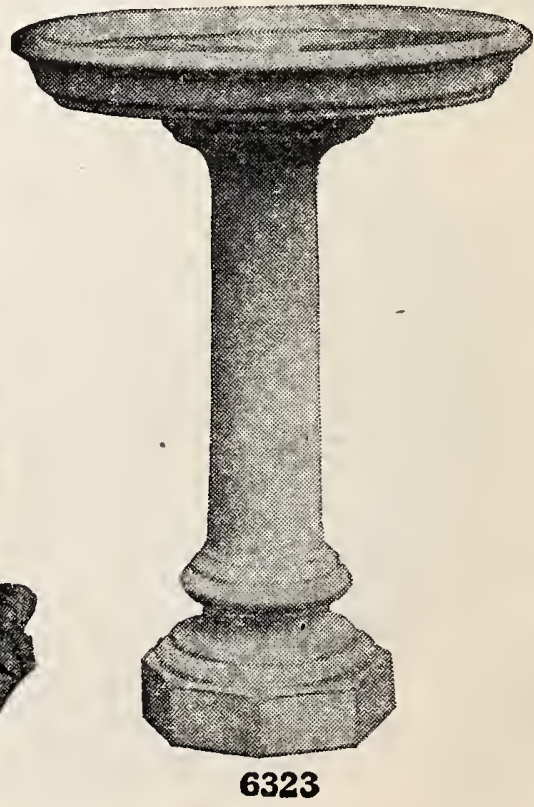




\section{Collins Highest-Grade Fertilizers}

Collins Sheep's Head Sheep Fertilizer, Pulverized. "A whole wagon load of rich fertilizer compressed into a bag." This is a splendid, concentrated fertilizer free from possibility of containing weed seeds, dried, ground to an even fineness, and packed in bags for convenient use. This drying process kills all the lurking weed seeds, making it exceedingly pure and clean to handle. It is exceedingly rich in nitrogen, phosphoric acid and potash, three very essential, enriching ingredients for any soil, and very important to the growing plants. Use it freely on your evergreens, flower beds and for roses. Easy to handle, clean and efficient; on lawns use ten pounds per hundred square feet. Price per $10 \mathrm{lb}$. trial bag, $75 \mathrm{cts}$; postpaid up to and including 4th postal zone; $100 \mathrm{lb}$. bag, $\$ 3.50$, express or freight.

Collins Bone Meal. Made of pure, raw bone, this is an ideal fertilizer for rose beds and for greenhouse work; safe and effective. $5 \mathrm{lbs}$. $50 \mathrm{cts}, ; 10 \mathrm{lbs} .80 \mathrm{cts}$., postpaid up to and including 4th Postal Zone; 25 lbs., $\$ 1.50 ; 50$ lbs., $\$ 2.50$, by express.

Collins Pleasant Valley Plant Food. A fertilizer or plant food that works wonders on indoor plants, evergreens, roses, lawns, etc. It contains $3 \%$ potash, $6.7 \%$ phosphoric acid and $21 / 2 \%$ nitrogen. $1 \mathrm{lb}$. carton $35 \mathrm{cts}$. postpaid; $4 \mathrm{lb}$. carton $\$ 1.15$, postpaid up to and including 4 th postal zone; $10 \mathrm{lb}$. carton, $\$ 2.45$, by express.

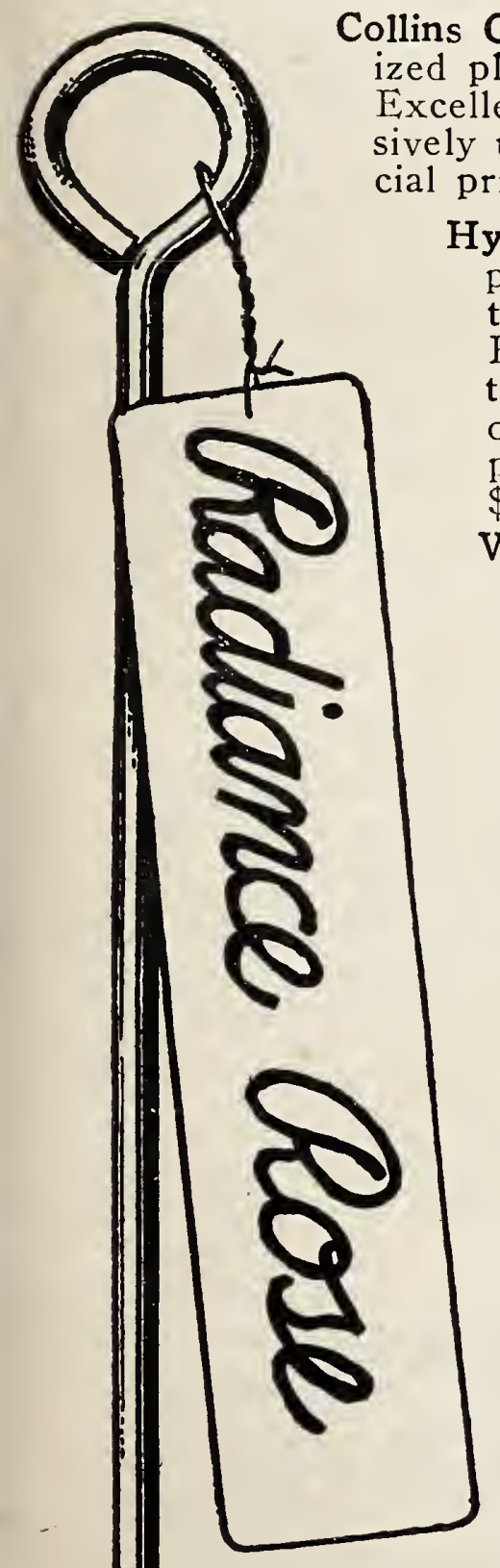

Crutch with metal label

You'll find Plant Crutches give a friendly support to planters, too.

Hyper Humus. Organic matter consisting of decomposed vegetable plants and is a very valuable food for perennials, roses, dahlias, vegetables, lawn, etc. Similar to Leaf Mould, but more concentrated. Renders clay soils lighter and sandy soils better able to retain moisture. It is the source of nitrogen and sets free for plant growth many otherwise insoluble mineral elements in the soil. $10 \mathrm{lbs}$. 60c, postpaid up to and including the 4th postal zone; $50 \mathrm{lbs}$. $\$ 1.35 ; 100 \mathrm{lbs}$. $\$ 2.25 ; 500$ lbs. $\$ 10.00 ; 1000$ lbs. $\$ 15.00$; per ton $\$ 25.00$.

Wood Ashes. Of unleached hard wood, a superior stimulant for roses, dahlias, etc. These are rich in readily available potash. $5 \mathrm{lbs}$. $60 \mathrm{c}$, postpaid up to and including the 4 th postal zone; 50 lbs. $\$ 2.00 ; 100$ lbs. $\$ 3.00 ; 500$ lbs. $\$ 12.00$; per ton, $\$ 40.00$.

COLLINS IMPROVED METAL LABELS. Made of copper, thus unaffected by weather. Identify vines, bushes, trees, etc., and record date of planting. To inscribe, simply place tag on folded newspaper and write with hard pencil. Long copper wire attached. $3 / 4 \times 31 / 2$ inches. Postpaid prices: $5 \mathrm{c}$ each; 50c per dozen; $\$ 3.00$ per box of 100 , in which we include one all-steel stylus free.

COLLINS PLANT CRUTCHES. Made of galvanized steel, they last a lifetime, are sharp pointed for quick and easy insertion. $2 \mathrm{r} / 2 \mathrm{ft}$. long. Will "give" slightly in the wind and "ease" the plant where wooden stakes will snap off. Take up little space in the tool-shed or cellar. Have a thousand uses.

\section{USES:}

1. Guide your plants upward.

2. Support plants throügh winds and rains.

3. Mark where bulbs or seeds are planted underground.

Plant Crutches: 75c per doz., postpaid. By express: 50 Crutches $\$ 2.00 ; 100$ Crutches $\$ 3.50 ; 1000$ Crutches $\$ 25.00$.

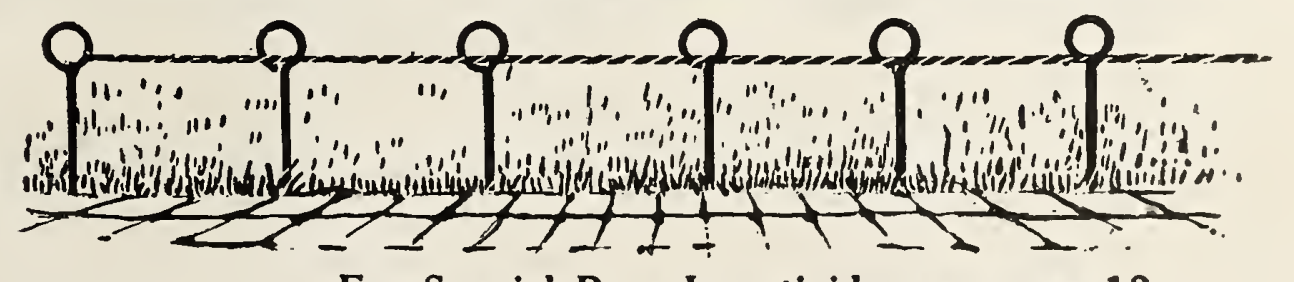

For Special Rose Insecticides see page 18 


\section{Note these money-saving SPECIAL OFFERS}

The only way a nursery can reduce prices on its plants, etc., without lowering quality standards, is by producing larger quantities of certain varieties and so grouping these that costs of assembling an order for packing and shipping are cut down. The Collins policy calis for grouping items-carefully selected as to color and growing habit, etc. - producing these in quantity and passing along to our customers the savings effected.

Before you mail your order, it will pay you to check the following items again:

Page

Asparagus. Special Offers

... 63

Berries. Special Offers

64 and 65

Cannas. Collins Select Dozen Cannas

(reg. value $\$ 4.20$ ) for $\$ 2.95 \ldots \ldots \ldots 51$

Dahlias

Color Plate offer of 5 Collins Dahlias, plus the golden "Eagle" FREE, for $\$ 1.95 \ldots \ldots \ldots \ldots \ldots 76$

Best New Dahlias for 1929 , including President Hoover, Arthur J. Collins and others (reg. value $\$ 14.00)$ for $\$ 12.40 \ldots \ldots \ldots \ldots \ldots 59$

Collins Super Dahlia Collection, including the best introductions of 1928 and 1929, plus 12 outstanding Giants, 23 tubers in all (reg. value $\$ 31.75)$ for $\$ 26.75 \ldots \ldots \ldots \ldots \ldots 60$

Other Dahlia offers, of all classes, 59 to 62

Evergreens

6 Beautiful Evergreens (color illustration) $\$ 10.00 \ldots \ldots \ldots \ldots \ldots . \ldots 36$

International Group, a rare value for $\$ 14.75 \ldots \ldots \ldots \ldots \ldots \ldots 35$

International Group, plus two Azalea Hinodigiri (worth \$5.00) for $\$ 17.75 \ldots \ldots \ldots \ldots \ldots \ldots \ldots \ldots . \ldots 29$

Landscape Offer, 9 splendid varieties (reg. value $\$ 33.00$ ) for $\$ 24.75 .34$

Window Box Assortments........ 72

Flowering Shrubs

Color Plate offer of twelve sturdy plants, bearing flowers or berries the year 'round, for $\$ 2.95 \ldots \ldots .38$ Other Shrub offers .......22 \& 25

\section{Fruit Trees}

Special group offers $\quad \ldots .68$ to 71

\section{Gladiolus}

Newest Creations for 1929, lu Glads of unusual color blendings (reg. value $\$ 3.60$ ) for $\$ 3.25 \ldots \ldots \ldots \ldots 53$
Surprise Mixture, 60 bulbs with a wide color range, for $\$ 1.95 \ldots \ldots 56$

Collins 8 color offer, 5 bulbs each of 8 desirable colors, 40 bulbs for $\$ 1.00 \ldots \ldots \ldots \ldots \ldots \ldots \ldots \ldots \ldots$

12 Ruffled Glads for $\$ 2.85 \ldots \ldots \ldots . \ldots 54$

12 Giant Glads (reg. value \$3.40) for $\$ 3.10 \ldots \ldots \ldots \ldots \ldots \ldots . \ldots 56$

Reliable Collection, 24 bulbs, for $\$ 1.50 \ldots \ldots \ldots \ldots \ldots \ldots . \ldots 57$

Other Gladiolus offers........53 to 57

Grape Vines

6 Grape Vines, asst., for $\$ 1.50$ (reg. value $\$ 2.10) \ldots \ldots \ldots \ldots \ldots \ldots 66$

5 Concord Grape Vines for $\$ 1.00 \ldots 67$

\section{Perennials}

Color Plate offer of 9 hardy plants, plus The Dazzler FREE (value $\$ 2.80)$ for $\$ 1.95 \ldots \ldots \ldots \ldots \ldots . \ldots 41$

Collins "Mum" color offer of 12 superb Chrysanthemums (value $\$ 3.00)$ for $\$ 1.95 \ldots \ldots \ldots \ldots \ldots . .1$

Other perennial special offers and color gardens ..........45, 47, 49

\section{Rock Gardens}

Group of 50 plants, $\$ 9.75 \ldots \ldots \ldots 50$

Group $B-25$ plants, $\$ 5.45 \ldots \ldots \ldots 50$

\section{Roses}

"FAULTLESS FIVE" Roses for $\$ 1.95 \ldots \ldots \ldots \ldots \ldots \ldots \ldots \ldots \ldots \ldots$

WORLD WIDE Group, 12 marvelous roses (regular value $\$ 12.85$ ), for $\$ 8.75 ; 6$ for $\$ 4.45$.

In colors on outside covers

Radio Introductions of 1928-29 (reg. value $\$ 2.50$ ) for $\$ 1.95 \ldots \ldots \ldots \ldots 13$

Gold Cup Collection of 10 newest and best varieties (reg. value $\$ 17.50)$ for $\$ 14.75 \ldots \ldots \ldots \ldots \ldots$. 5

Rose Groups, by colors …........ 9

Climbing Rose Offers ......... $10 \% 11$

If your order totals $\$ 5.00, \$ 15.00$, or $\$ 25.00$, note advantage in re ROSES FREE, on facing page.

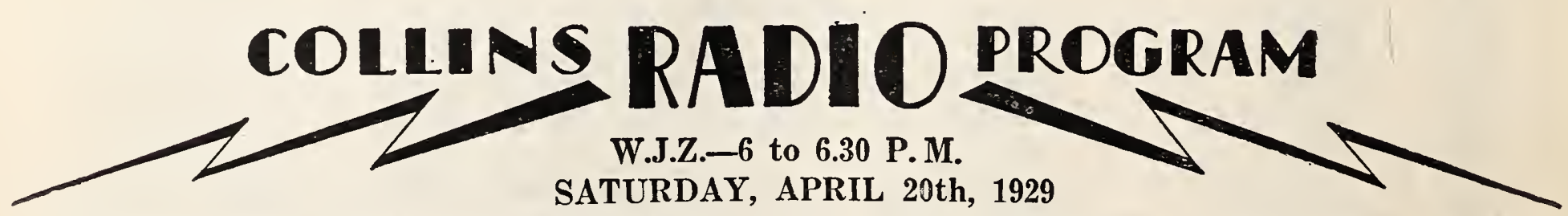

Mighty Like a Rose-Opening Theme

The Mill

Soul of the Rose (Vocal)

Desert Flower

Helpful Talk on Rose Culture
Sunshine, Roses, and You (Vocal)

Lay My Head Beneath a Rose

Where the Shy Little Violets Grow (Voc.)

Minuet 


\section{Roses FREE}

(See box at right)

THESE ROSE GIFTS FROM COLLINS NURSERIES are made to you for a double purpose; first to show you that we appreciate your order, and second to acquaint you with COLLINS big, sturdy rose bushes. These bushes MUST BE ASKED FOR at the time of placing your order with us, so we shall know you want them and can pack and ship with your other plants. After completing your order, just add a note across the blank, asking for the gift to which the size of your order entitles you.

\section{Before making out your order}

PRINT your name and address clearly on the orde Miss. In all subsequent correspondence sign the name and address exactly as it appeared on the order blank. With thousands of orders in our files practically all of the delay in answering correspondence is brought about by the fact that it is sometimes almost impossible to locate the original order because of the changing of the first name (as signing Mrs. Mary Smith in subsequent letters when the order blank was signed Mrs. John W. Smith) or through using a post office box number when the original order contained a street address.

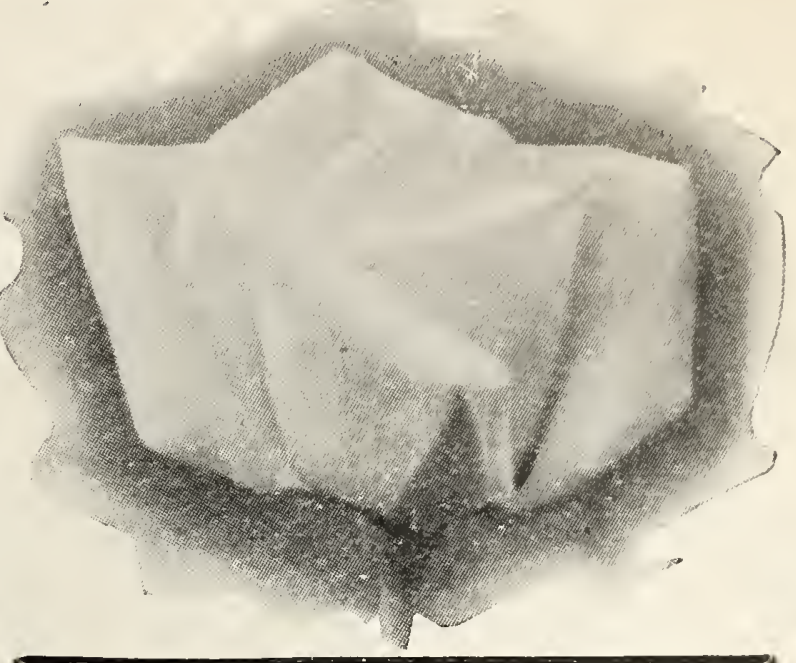

Notice that many items are offered Postpaid.

Gift One-One big thrifty field-grown rose bush FREE with every $\$ 5.00$ order.

Gift Three. Three of our wonderful World Wide Roses (our selection), shown in color on outside covers, FREE if your order amounts to $\$ 15.00$ or more.

Gift Six. One World Wide Group of 6 Roses, shown on outside covers, FREE if your order amounts to $\$ 25.00$ or more.

Don't fail to ask for the gift to which you are entitled-see paragraph at left. anywhere in the United States. Outside U. S., add $50 \mathrm{cts}$. to your order.

All Perennials, Dahlias, Gladiolus, etc., and many real money-saving offers, are sent postpaid for prices shown.

Large articles, as Fruit Trees, Hedge Plants and Fertilizers, over $10 \mathrm{lbs}$, will be sent by Express or Freight, customers paying transportation charges on arrival.

Shipments are occasionally made in more than one package, the first being released and not held until the others are prepared. However, we reserve the right to include "Postpaid" items in "Express" shipments to expedite filling of orders, since at best the digging and packing season is all too short.

5 will be sold at the 10 rate, 50 at the 100 rate, 500 at the 1,000 rate.

Terms Cash. Our terms are cash with order. As an inducement to send cash, we give you the benefit of the low prices named in this catalogue. Remittances may be made by Post-Office Order on Moorestown, N. J., or by Check or Registered Letter.

Substitution. It is our custom, should the supply of a variety be exhausted, to substitute in its place another, similar or better, correctly labeled. If it is desired that we shall not do this, affix to the order the words "no substitute."

Guarantee and Conditions of Sales. Purchasers are hereby notified that although we shall continue to take all possible care to supply good, healthy, thrifty trees, shrubs and plants true to name, and hold ourselves in readiness to replace, on proper proof, all stock that may prove untrue to name or refund the amount paid; we do not give any other warranty, express or implied, with respect to the goods we send out, and shall in no way be responsible for other defects or loss of crops. Every order received for articles named in this catalogue will be received and executed on the above conditions only, and with the distinct understanding and agreement on the part of the purchaser that we shall in no case be liable for a greater amount than the sum originally paid to us for the stock in question. Claims, if any, must be made upon receipt of goods, or they will not be allowed. 


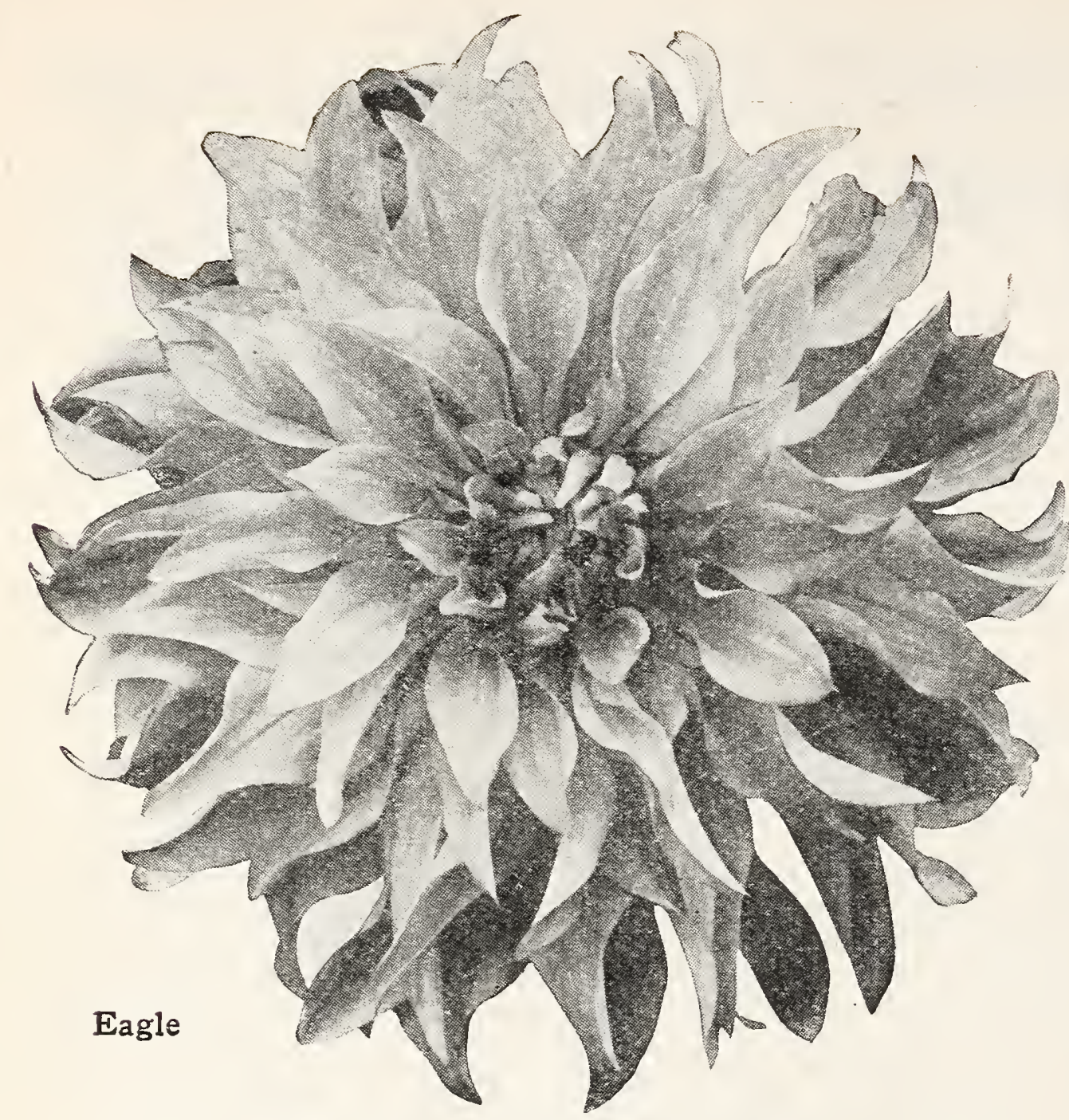

Every collection grown is our best advertisement; hence our offer:

\section{FREE}

This gorgeous yellow chrysanthemumflowered dahlia, "THE EAGLE," to each of the first 2000 customers ordering the 5 fine dahlias illustrated on color plate on facing page.

Nothing is harder to illustrate adequately in natural colors than the finer types of dahlias.

The color illustration loses much of true coloring unless examined in daylight.

As to size, the illustration falls far short of conveying the right impression. The average garden bloom of the Elizabeth Slocombe, if laid on the facing color illustration, would hide nearly the whole page - yet space requires that four other varieties be placed on the same plate.

\section{Collins Dahlias $\$ 1 .{ }_{\text {Potppaid }}^{95}$}

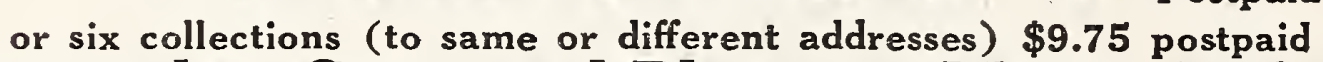

\section{Guaranteed to Grow and Bloom or Money Refunded}

RENE CAYEUX. A gem of the favorite Cactus type. Clear, sparkling, cardinal red blooms, glowing intensely with a uniform color throughout the flower. The flowers, borne on good stems, seem to be imperishable in the house. Produces flowers in six to eight weeks after planting, continuing until frost. Hundreds of blooms per plant are produced each season. A favorite with everyone who grows it.

BERTHA STORY. A gigantic Decorative Dahlia of beautiful rose-pink, with light lavender suffusions; occasionally white petals appear which add to its attractiveness. Long, graceful stems, often two feet in length. Splendid for exhibition; a very desirable cut-flower and garden variety.

NOIR ALVAREZ. A rich, deep, velvety, ox-blood red, almost black; of fine texture, with long petals of beautiful formation. Best of its color. A good bloomer, with long stems, making it desirable for cutting. The plants are tall and vigorous.

DARLENE. The finest of cut-flower Dahlias. An exquisite live, shell-pink, with a dainty blend of white at the center. Blooms very early and abundantly. Stems long and sturdy, flowers uniform and perfect, an ideal Decorative Dahlia.

ELIZABETH SLOCOMBE. A giant among giants; unquestionably the largest and best of its color. A strong, vigorous grower making a splendid effect in the garden. Opens as brilliant, glowing purple, and matures into a purple-garnet that grips you, a rare shade, much desired. Fine for exhibition or cut-flower purposes.

Plant the tubers this Spring and cut flowers from the rugged, prolific plants from August till late November. Fill vase after vase of rich, intensely colored bloomsexhibit in your neighborhood Dahlia Show this Autumn.

There is no end of the pleasures which await you in this collection. Send in your order now and get the yellow "Eagle" as well, FREE. 


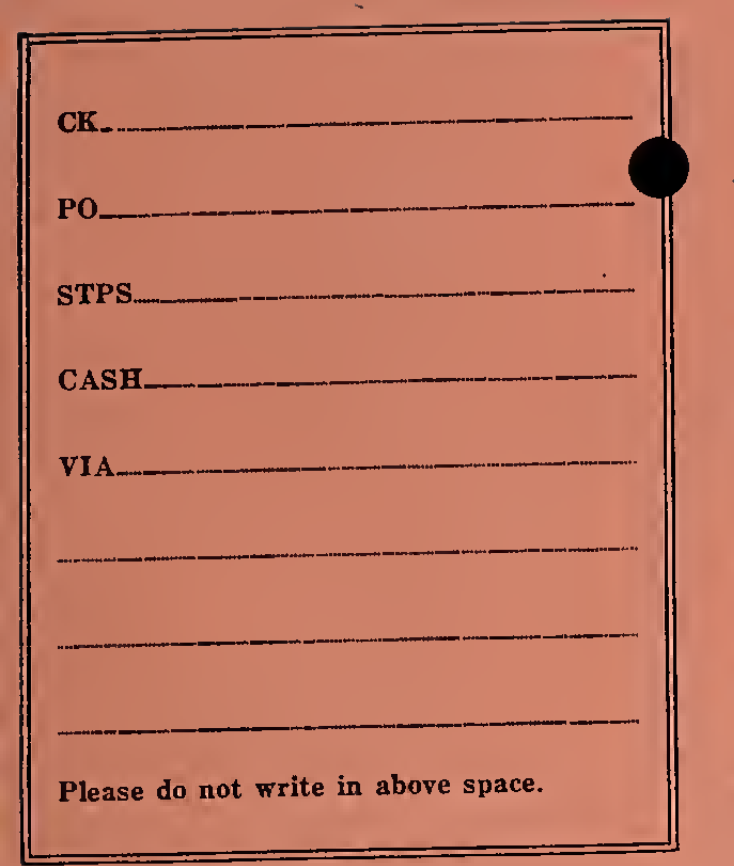

\section{COLLINS NURSERIES}

ESTABLISHED 1860

ARTHUR J. COLLINS \& SONS, Inc.

MOORESTOWN

\section{ORDER SHEET}

(Burlington Co.) New Jersey

Name... Fili out fully and with care. Please print.

Street.

Post Office.

Express Office

County.

State

Date.

Do you wish us to substitute to the best of our judgment in case

Write Yes or No

Amount enclosed \$.

\section{VERY IMPORTANT}

No matter how often you have written us, always give your full Address, and write your name, Post Office, County and State very plainly.

Articles Wanted

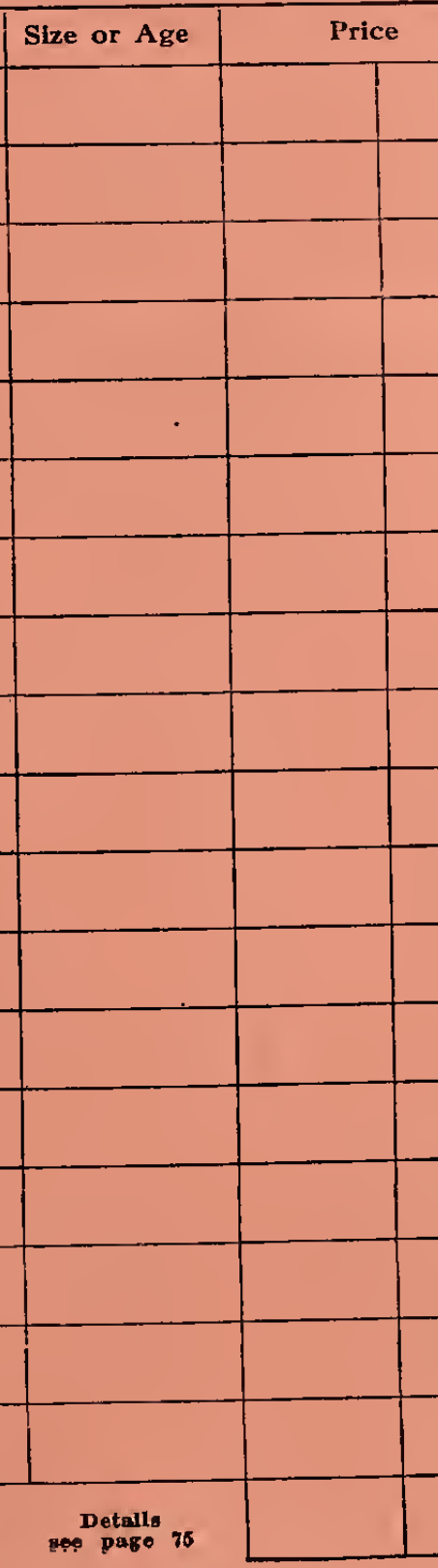




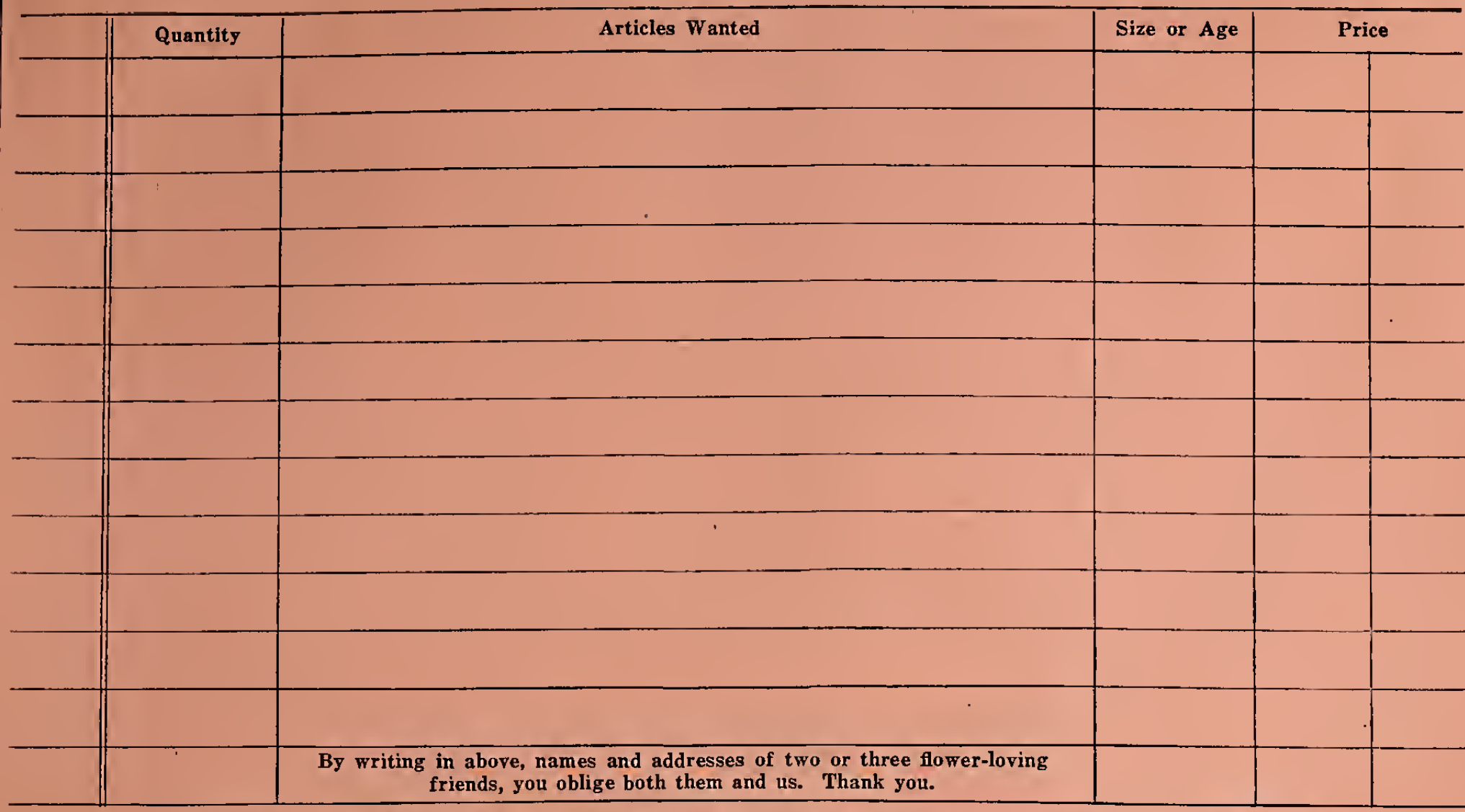

\section{Before You Mail This Order Blank Read SPECIAL OFFERS, Page 74}

\section{What Collins Quality has done for others, it will do for you}

Shrubs double the size expected The seventy-five assorted shrubs and fine flowering trees arrived this morning. They all arrived in wonderful condition, and $1 \mathrm{am}$ agreeahly sur. prised at the big, sturdy shrubs-fully twice as big as I bad expected.

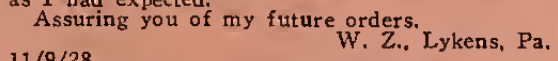$$
11 / 9 / 28
$$

Rose bushes especially pleasing I received balance of $\mathrm{my}$ order Monday noon and am very much pleased with them, and the rose bushes look.

$11 / 14 / 28$

I. N. H., Wilson, Conn.

Shrubbery pleases Minnesota Customer We received our shrubbery in good condition and we are very much pleased with it.

$11 / 13 / 28$

P. C. S., Sauk Rapids, Minn.

Fruit trees fine-like everything else

The fruit trees are fine specimens, as we have found everything we liave received from you to be perfect.

$11 / 26 / 28$

Mrs. R. W. DesJ., South Bend, Ind.

Evergreen group pleases Pennsylvania purchaser

The Collins 1928 Landscape Collection was indeed very nice and was admired hy everyone. $8 / 1 / 28$

Dahlias and Garden Loam prove satisfactory Please send me 3 bags of your fine Garden
Loam. I have used it for a valuable tree and it bas done well for it. The Dahlias are heautifu. and hloom freely. A. B. H., Atlantic City, N. J.
Mrs. S. A. $8 / 1 / 28$

Roses have bloomed all SummerVirginia

The roses I bougbt from you are doing fine. Simply gorgeous thooms constantly through our hottest summer.

Mrs. S. S., Norfolk. Va

\section{Typical Re-Orders}

I am delighted with the roses received in 'my previous orders from you. I am enclosing check for Unique Rock Garden Collection and group of Cactus. These duplicate goods I bought previously whicb have been admired by all who have seen them,

I have bought roses of you for several years and can heartily recommend your stock as A No. 1. Please send me your 1928 Catalog. Are you offering any different roses this year in the $\$ 1.95$ for 5 Collections?

$1 / 18 / 28$

Mrs, C. E. W., Des Moines, Iowa.

The apple and pear trees my father got from you about 20 years ago are in fine hearing condition. Every purchase be or I have made from you is entirely satisfactory. Pbiladelphia, $\mathrm{Pa}$

The Collection of roses I bought from you are wonderful, everybody talks about them. This morning I have 5 perfect I want to get some more just like these. When can you send them, per enclosed order?

Mrs. V. M. C., Cherrytree, Pa.

Last spring I sent for Collins Faultless Five roses, almost afraid they were too cheap to be good. We were so pleased with the worderul bushes and the gorgeous blooms they bore, we the Nizera flower and seed catalog away bat Collins.

If at any time you have a doubtful customer in this territory refer them to me. I will tell them how pleased I bave been with all my purchases from you. Other roses I bought elsewbere at far higber prices can't compare in color, fragrance, or profusion of bloom.
$8 / 24 / 28$

J. J. M., Carbondale, $\mathrm{Pa}$.

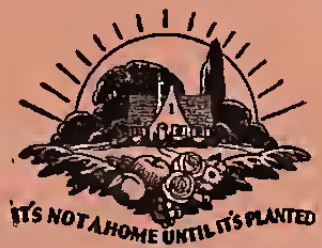

MEMBER, AMERICAN ASSOCIATION OF NURSERYMEN
"Faultless Five" surpass roses at several times the cost

The Faultiess Five roses have far surpassed any otber rose bushes I have hought: though I paid in vigor, appearance, growth and size and quality of hloom.

$9 / 3 / 28$

F. L. W., Wilmington, Del.

Picks three blooms at end of November, in New York

My Collins Roses are the talk of the neighbor. hood and today, even at this late date, I picked three beautiful blooms from them. Such perfect flowers all summer and up to Thanksgiving Da $11 / 28 / 28$

July crop from Collins Faultless Five, 216 Blooms

This year I have had wonderful blooms from last year's Faultless Five rose collection. I bave cut buds as soon as they were opened enough. and so far in July have had 216 beauties; and now the second crop is starting. The bushes are loaded with buds. Two neighbors bought your roses this year and both have had remarkable success with
them.

$7 / 30 / 28$

Cannas please Michigan buyer The Cannas bought this year are a thing of heauty. They please me just as my rose brshes did-and they were the finest hushes I ever boug $9 / 4 / 28$

Mrs. E. J., Berkley, Michigan.

Cactus and Spirea both highly pleasing

The Cactus plants are certainly nice. I bave never seen such interesting. wonderful plants hefore. The Spirea were highly satisfactory also. $11 / 18 / 28$ 


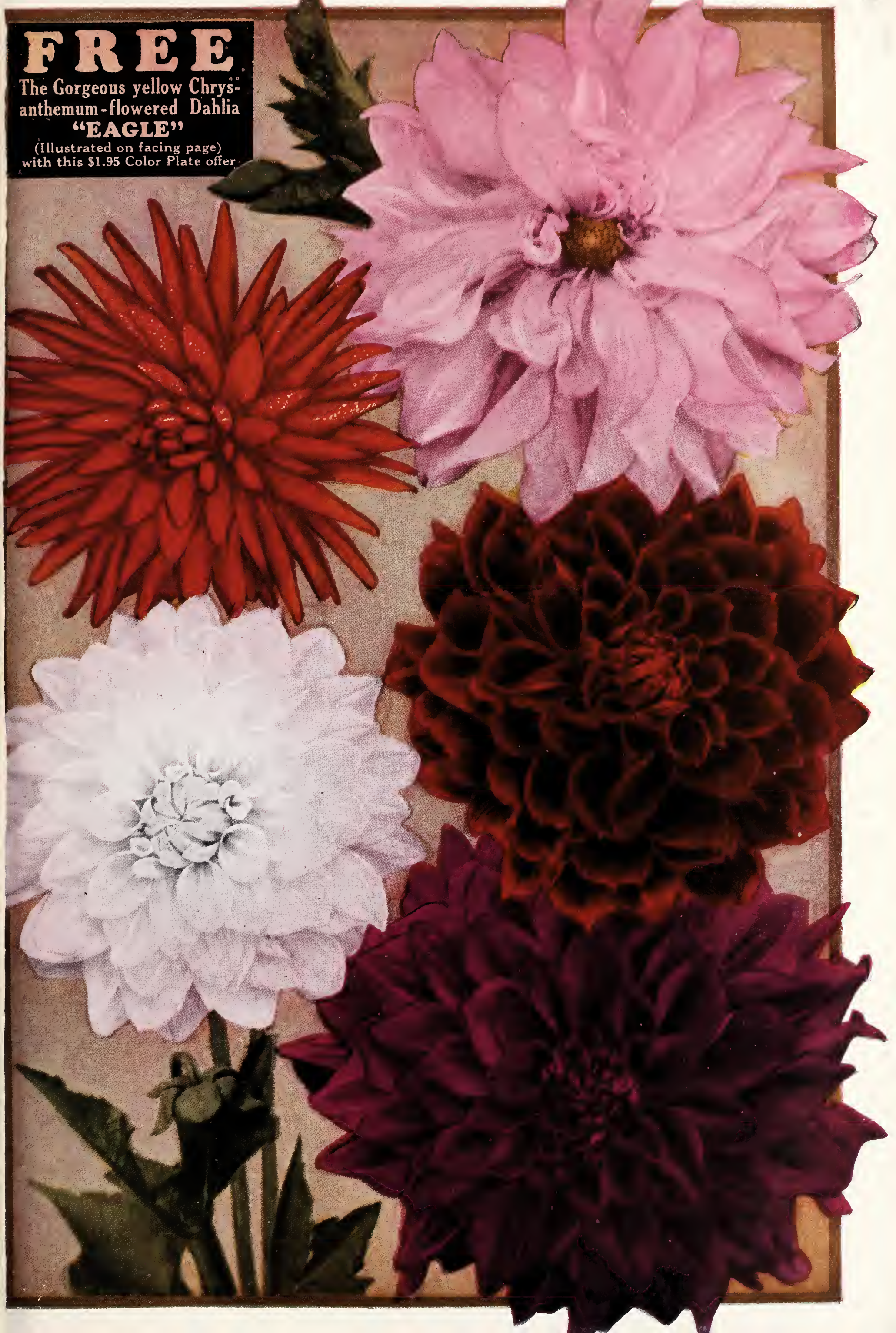




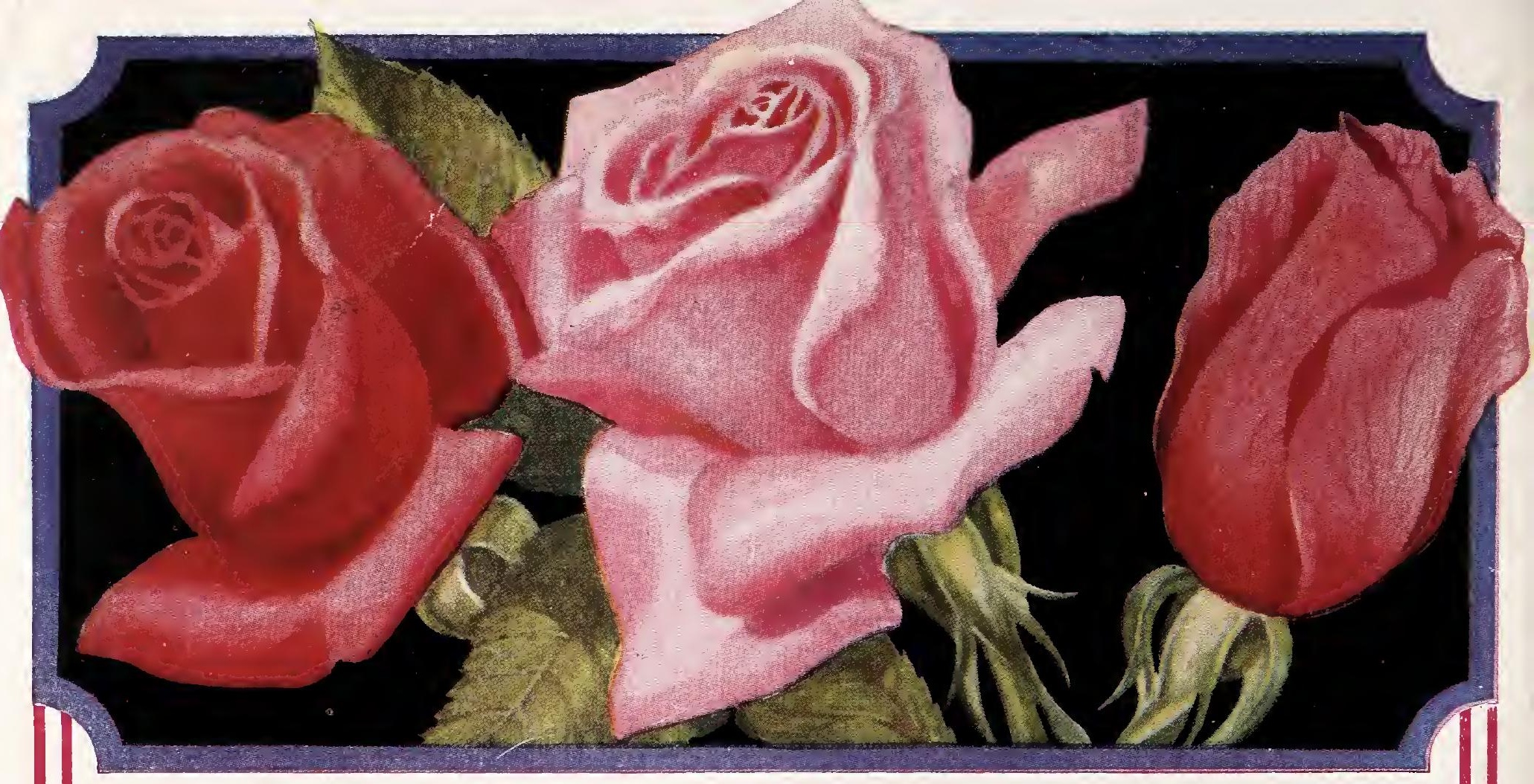

\section{The World's Finest Twelve Monthly Roses COLLINS 1929 WORLD-WIDE ROSE GROUP}

is the answer to your question, "What are the twelve finest monthly roses for my garden?" They excel not in one characteristic only, but in perfection of bud, in glory and profusion of bloom, in color, fragrance and hardiness.

SOUVENIR DE GEORGES PERNET -Fiery oriental crimson, with golden sheen.

MME. CAROLINE TESTOUT-Large, fragrant flowers of clear pink, edged silvery rose.

ETOILE DE FRANCE-Very fragrant crimson, with deeper markings.

BETTY-Bears profusely, especially in autumn. Deliciously scented, copperyrose, suffused yellow.

MISS LOLITA ARMOUR-Carminered, suffused copper and gold.

LADY ALICE STANLEY-Coral-rose outside of panels, and inside flesh-pink.
SUNBURST-Yellow with deep orange center. Exquisite in form and scent.

DUCHESS OF WELLINGTON-Intense saffron-yellow opening to deep copper-yellow.

HOOSIER BEAUTY-Exquisitely long buds, opening to immense, dazzling-scarlet fragrant flowers.

MME. BUTTERFLY-Bright rose-pink blooms, blending to apricot and gold at base.

MRS. AARON WARD-Most abundant blooming yellow. Indian yellow centers, shading light toward edges.

MME. EDOUARD HERRIOT-Coral red, yellow-shaded, opening to scarlet, copper-shaded.

Only the newer, lesser known of these finest monthly roses can be shown in color here; nor is it possible for any color-photographer to reproduce a fraction of their true beauty. To appreciate their superiority, you should have at least one plant of each. So long as our supply lasts, we make tire following special offers, on big, thrifty 2-year-old, No.1, field groun plants.

GUARANTEED to grow and bloom this season or money refunded

\section{2 of each variety above $\$ 8.75$}

Delivered
$6 \begin{aligned} & 2 \text { yr. old bushes from } \$ 4.45 \\ & \text { above dozen varieties }\end{aligned}$

Delivered

Please understand that no change of assortment can be permitted at these prices. The dozen lot includes one bush each of the dozen varieties described above; the six group will be carefully selected by us to give you maximum color range, selections being made by us as orders are received. First come, first served. But specific varieties cannot be guaranteed on orders for six bushes.

Shipment will be made at proper planting time.

Never before have we made so low a price on these bushes; nor given a guarantee; and both price and guarantee are restricted to stock set aside for the above remarkable introductory offers. 